\section{Pacific Northwest}

National Laboratory

Operated by Batielle for the

J.S. Depirtment of Energy

\section{B orehole D ata Package for Calendar Year 2000-2001 RCRA Wells at Single-Shell Tank Waste Management Area TX-TY}

D. G. Horton

F. N. Hodges

August 2001

Prepared for the U.S. D epartment of Energy under Contract DE-AC06-76RL01830 


\section{DISCLAIMER}

This report was prepared as an account of work sponsored by an agency of the United States Government. Reference herein to any specific commercial product, process, or service by trade name, trademark, manufacturer, or otherwise does not necessarily constitute or imply its endorsement, recommendation, or favoring by the United States Government or any agency thereof, or Battelle Memorial Institute.

\section{PACIFIC NORTHWEST NATIONAL LABORATORY operated by \\ BATTELLE for the UNITED STATES DEPARTMENT OF ENERGY under Contract DE-ACO6-76RL01830}




\title{
Borehole Data Package for Calendar Year 2000-2001 RCRA Wells at Single-Shell Tank Waste Management Area TX-TY
}

\author{
D. G. Horton \\ F. N. Hodges
}

August 2001

Prepared for

the U.S. Department of Energy

under Contract DE-AC06-76RL01830

Pacific Northwest National Laboratory

Richland, Washington 99352 


\section{Contents}

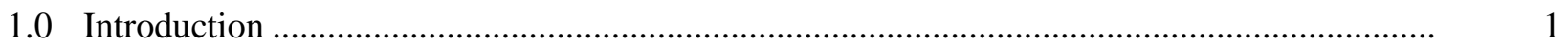

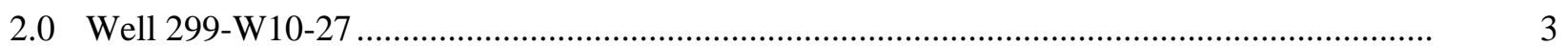

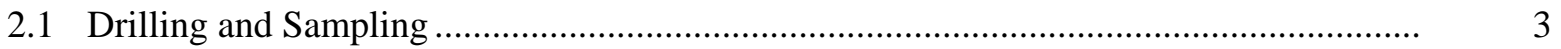

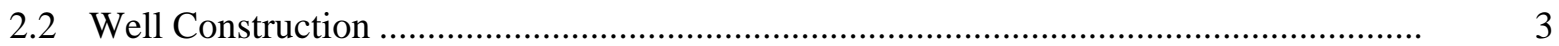

2.3 Well Development and Pump Installation................................................................ 5

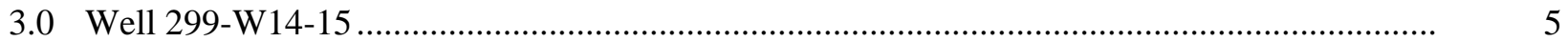

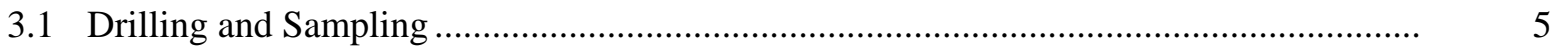

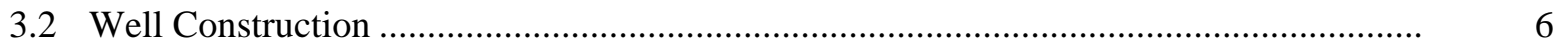

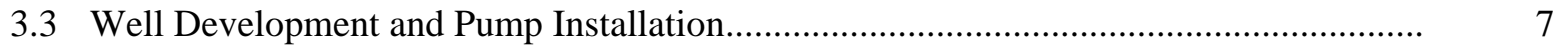

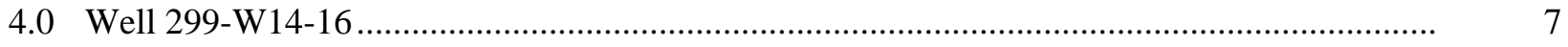

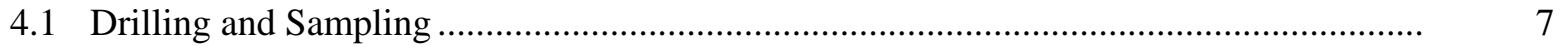

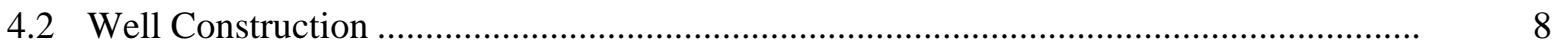

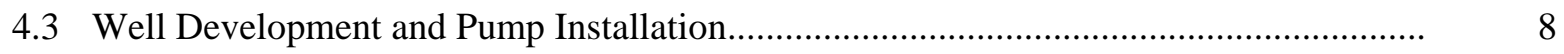

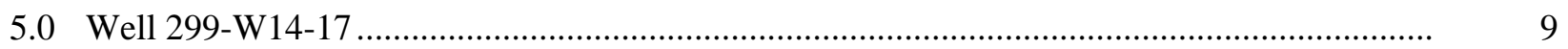

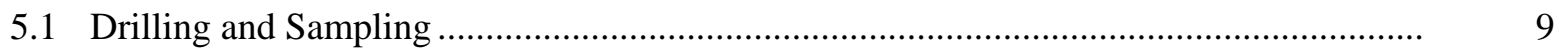

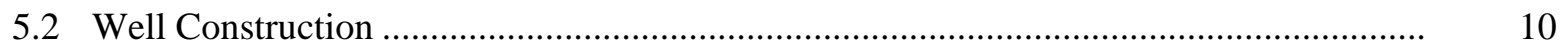

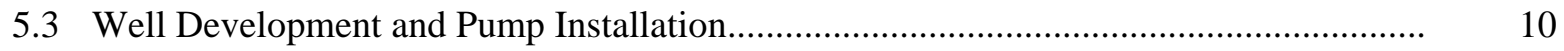

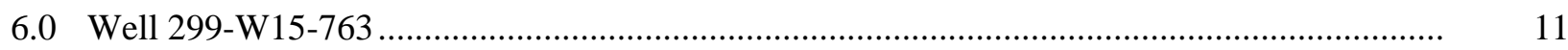

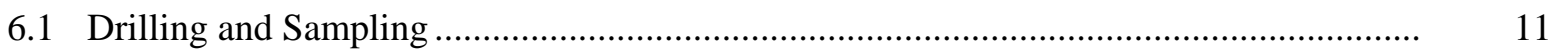

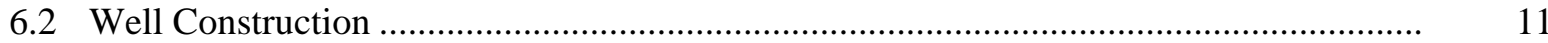

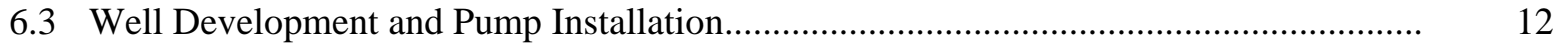

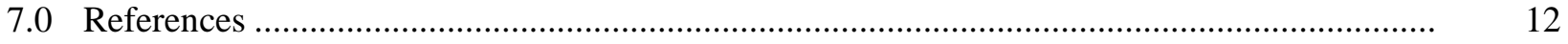

Appendix A - Well Construction and Completion Documentation ............................................... A.1

Appendix B - Physical Property Data …..................................................................................... B.

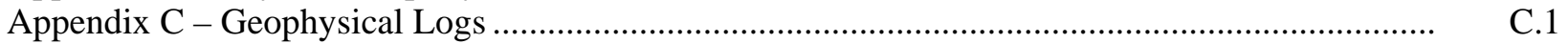




\section{Figure}

1 Map of Waste Management Area TX-TY and Locations of Wells in the Groundwater

Monitoring Network

\section{Tables}

$1 \quad$ Well Names and Well Numbers for New Wells at Waste Management Area TX-TY ............. 1

2 Survey Data for New Wells at Waste Management Area TX-TY ...........................................

3 Results of Groundwater Analyses from Samples from New Wells at Waste Management Area TX-TY 


\subsection{Introduction}

Five boreholes were drilled at the single-shell tank farm Waste Management Area (WMA) TX-TY in August 2000 through March 2001. The wells are 299-W10-27, 299-W14-15, 299-W14-16, 299-W14-17, and 299-W15-763. Table 1 lists the well names and well numbers. The five wells were installed as Resource Conservation and Recovery Act (RCRA) groundwater monitoring wells in fulfillment of Tri-Party Agreement (Ecology et al. 1998) milestones M-24-00L and M-24-00M. Well 299-W10-27 is located at the northeast corner of TY tank farm and is a new downgradient well in the monitoring network. Well 299-W14-15 is a new downgradient well on the east side of TX tank farm. Wells 299-W14-16 and 299-W14-17 are located to the east of the TX tank farm and were constructed to help define the extent of contamination. Well 299-W15-763 is on the south side of TX tank farm and is a replacement for well 299-W15-4, which is dry. The locations of all wells in the WMA TX-TY monitoring network are shown on Figure 1.

The original assessment monitoring plan for WMA TX-TY was issued in 1993 (Caggiano and Chou 1993). That plan was updated for the continued assessment at WMA TX-TY in 2001 (Hodges and Chou 2001). The updated plan provides justification for the new wells. The new wells were constructed to the specifications and requirements described in Washington Administrative Code (WAC) 173-160 and WAC 173-303, the updated assessment plan for WMA TX-TY (Hodges and Chou 2001), and the description of work for well drilling and construction. ${ }^{(a)}$

This document compiles information on the drilling and construction, well development, pump installation, and sediment and groundwater sampling applicable to the installation of new wells in calendar year 2000-2001 at WMA TX-TY. Appendix A contains the Well Summary Sheets (as-built diagrams), the Well Construction Summary Reports, and the geologist's logs; Appendix B contains physical properties data; and Appendix $\mathrm{C}$ contains the borehole geophysical logs. Additional documentation concerning well construction is on file with Bechtel Hanford, Inc., Richland, Washington.

Table 1. Well Names and Well Numbers for New Wells at Waste Management Area TX-TY

\begin{tabular}{|c|c||}
\hline Well Name & Well Number \\
\hline \hline 299-W10-27 & C3125 \\
\hline 299-W14-15 & C3114 \\
\hline 299-W14-16 & C3120 \\
\hline 299-W14-17 & C3121 \\
\hline 299-W15-763 & C3339 \\
\hline
\end{tabular}

(a) Letter from J. S. Fruchter, Pacific Northwest National Laboratory, to G. C. Henckel, Bechtel Hanford, Inc., "Description of Work for Drilling CY 2000 RCRA Groundwater Monitoring Wells," dated May 12, 2000. 


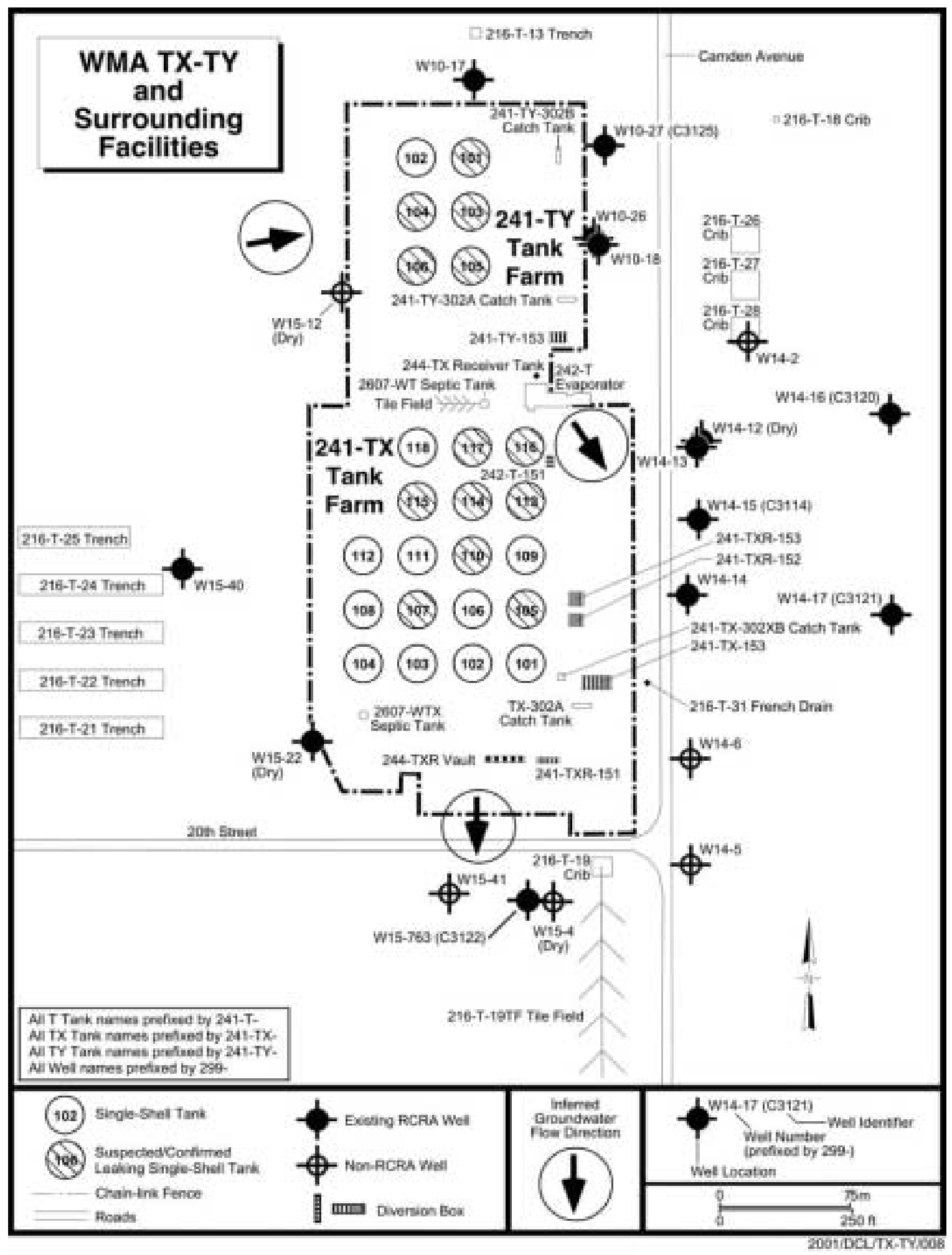

Figure 1. Map of Waste Management Area TX-TY and Locations of Wells in the Groundwater Monitoring Network 
English units are used in this report because that is the system of units used by drillers to measure and report depths and well construction details. To convert feet to meters, multiply by 0.3048 ; to convert inches to centimeters multiply by 2.54 .

\subsection{Well 299-W10-27}

Well 299-W10-27 was drilled from January through March 2001. The well is located on the northeast side of TY tank farm.

\subsection{Drilling and Sampling}

Well 299-W10-27 was drilled with a cable tool drill rig to a total depth of $268.7 \mathrm{ft}$ below ground surface (bgs). Temporary 11 3/4-in.-outside-diameter, carbon steel casing was placed from the surface to $56 \mathrm{ft}$; 8 5/8-in.-outside-diameter, carbon steel casing was placed from the surface to total depth. The borehole was advanced with a drive barrel from 0 to $132.5 \mathrm{ft}$ and with hard tool from 132.5 to $268.7 \mathrm{ft}$ bgs. At least 246 gal of water were added to the borehole during hard tool drilling.

Sediments encountered during drilling were Hanford formation sand, sandy gravel, and silty sandy gravel from 0 to $41 \mathrm{ft}$ and sand from 41 to $89 \mathrm{ft}$ bgs. Plio-Pleistocene silt was encountered from 89 to $98 \mathrm{ft}$ bgs and Plio-Pleistocene silty sand with caliche from 98 to $124.5 \mathrm{ft}$ bgs. Ringold Formation silty sandy gravel was found from $124.5 \mathrm{ft}$ to total depth. A possible clastic dike was noted by the geologist at $117 \mathrm{ft}$ bgs. A geologist's log is included in Appendix A.

The borehole was continuously sampled by split spoon from $52.5 \mathrm{ft}$ to $132.5 \mathrm{ft}$ depth. Additional split spoon samples were taken at 226 to $227 \mathrm{ft}, 241$ to $242 \mathrm{ft}$, and 254 to $256 \mathrm{ft}$ depth for analysis of particle size distribution. The particle size data is included in Appendix B. Also, grab samples of sediment for geologic description and archive were collected at approximate 5-ft intervals throughout the borehole.

The borehole and drill cuttings were monitored regularly for organic vapors and radionuclide contaminants. The drill cuttings at a depth of $17 \mathrm{ft}$ were about 20 counts per minute (beta-gamma) above the background value of 350 counts per minute. Sediments were also slightly above background at $100 \mathrm{ft}$ bgs.

The borehole was geophysically logged with spectral gamma-ray and neutron moisture tools on March 15, 2001. No manmade radionuclides were identified.

\subsection{Well Construction}

The permanent casing and screen were installed in well 299-W10-27 March 2001. A 4-in.-innerdiameter, stainless steel, continuous wire-wrap (20 slot) screen was set from 256.0 to $221.0 \mathrm{ft}$ bgs. The 
permanent casing is 4-in.-inner-diameter, stainless steel from $221.0 \mathrm{ft}$ bgs to $2.0 \mathrm{ft}$ above ground surface. A 2-ft-long sump was installed below the screen from 257.9 to $256 \mathrm{ft}$.

The filter pack is 10 to 20 mesh silica sand from $263.3 \mathrm{ft}$ to $210.0 \mathrm{ft}$ bgs. The annular seal is bentonite pellets from $210.0 \mathrm{ft}$ to $204.6 \mathrm{ft}$ bgs, granular bentonite from 204.6 to $10.9 \mathrm{ft}$ bgs, and Portland cement from $10.9 \mathrm{ft}$ to the surface. A $4 \mathrm{ft}$ by $4 \mathrm{ft}$ by 6 in. concrete pad was placed around the well at the surface. A 6-in. stainless steel protective casing with locking cap, four protective steel posts, and a brass marker stamped with the well number were set into the concrete. The inner casing extends $2.0 \mathrm{ft}$ above the concrete pad and the protective casing extends $3.0 \mathrm{ft}$ above the concrete pad. The Well Construction Summary Report and the Well Summary Sheet (as-built) are included in Appendix A.

The vertical and horizontal coordinates of the well were surveyed in May 2001. The horizontal position of the well was determined by Global Positioning System observations referenced to horizontal control stations established by Rogers Surveying, Inc., Richland, Washington, and the U.S. Army Corps of Engineers. The coordinates are Washington Coordinate System, South Zone, NAD83(91) datum. Vertical datum is NAVD 1988 and is based on existing bench marks established by the U.S. Army Corps of Engineers. Survey data are included in Table 2.

Table 2. Survey Data for New Wells at Waste Management Area TX-TY

\begin{tabular}{|c|c|c|c|c|}
\hline Well Name & $\begin{array}{l}\text { Easting } \\
(\mathrm{m})\end{array}$ & $\begin{array}{l}\text { Northing } \\
\text { (m) }\end{array}$ & $\begin{array}{c}\text { Elevation } \\
(\mathrm{m})\end{array}$ & \\
\hline \multirow{3}{*}{ 299-W10-27 } & $566,843.969$ & $136,441.778$ & & Center of Casing \\
\hline & & & 205.624 & Top of Casing \\
\hline & $566,843.969$ & $136,442.111$ & 204.899 & Brass Cap \\
\hline \multirow{3}{*}{ 299-W14-15 } & $566,899.685$ & $136,230.654$ & & Center of Casing \\
\hline & & & 205.354 & "X" on Rim of Casing \\
\hline & $566,899.661$ & $136,231.044$ & 204.584 & Brass Cap \\
\hline \multirow{3}{*}{ 299-W14-16 } & $567,001.334$ & $136,318.482$ & & Center of Casing \\
\hline & & & 206.123 & "X" on Rim of Casing \\
\hline & $567,001.390$ & $136,318.742$ & 205.368 & Brass Cap \\
\hline \multirow{3}{*}{ 299-W14-17 } & $567,006.773$ & $136,218.349$ & & Center of Casing \\
\hline & & & 205.853 & "X" on Rim of Casing \\
\hline & $567,006.644$ & $136,218.746$ & 205.079 & Brass Cap \\
\hline \multirow{3}{*}{ 299-W15-763 } & $566,809.207$ & $136,028.763$ & & Center of Casing \\
\hline & & & 202.947 & Top of Casing \\
\hline & $566,809.177$ & $136,029.053$ & 202.175 & Brass Cap \\
\hline
\end{tabular}




\subsection{Well Development and Pump Installation}

Well 299-W10-27 was developed in March 2001. A temporary, $3 \mathrm{hp}$, submersible pump was used for development with the intake at $251.66 \mathrm{ft}$ bgs (29.6 ft below the water table). During initial development at $7 \mathrm{gal} / \mathrm{min}$, there was $27 \mathrm{ft}$ of drawdown. In order to keep sufficient water above the pump intake for development, about 200 gal of water were added to the well from a decontamination tank. The added water contained about 2/3 pt of CLR Calcium Lime and Rust Remover. This was discovered when the geologist found foam in the water being pumped from the well. Approximately 1,800 gal of potable water were injected into, and pumped out of, the well to flush the well of the added chemical. After pumping the 1,800 gal of added water, about $420 \mathrm{gal}$ of formation water were pumped at a rate of $1 \mathrm{gal} / \mathrm{min}$ resulting in about $25.6 \mathrm{ft}$ of drawdown. Final turbidity was $102 \mathrm{NTU}$ and $\mathrm{pH}$ was 8.4.

A dedicated submersible sampling pump was installed in well 299-W10-27 on April 2, 2001. The sampling pump intake is at $251 \mathrm{ft}$ bgs (or about $29.9 \mathrm{ft}$ below the water table). Static water level was measured at $221.11 \mathrm{ft}$ bgs on April 2, 2001.

\subsection{Well 299-W14-15}

Well 299-W14-15 was drilled in August 2001. The well is located on the northeast side of the TX tank farm.

\subsection{Drilling and Sampling}

The borehole was drilled by cable tool from the surface to $20.7 \mathrm{ft}$ bgs and by air rotary from $20.7 \mathrm{ft}$ to a total depth of $260 \mathrm{ft}$ bgs. Temporary 11 3/4-in.-outside-diameter, carbon steel casing was placed from 0 to $20.7 \mathrm{ft}, 85 / 8$-in.-outside-diameter carbon steel casing was placed from $20.7 \mathrm{ft}$ to $260 \mathrm{ft}$ bgs. At $18.5 \mathrm{ft}$, $20 \mathrm{gal}$ of water were added to the borehole to hydrate the bentonite used as a seal where downsizing casing.

Sediments encountered during drilling were Hanford formation silty sand, gravelly silty sand, and silty sandy gravel from the surface to about $37 \mathrm{ft} \mathrm{bgs}$ and sand from $37 \mathrm{ft}$ to about $88 \mathrm{ft}$ bgs. Silty sand and calcareous slightly silty sand of the Plio-Pleistocene occurred from $88 \mathrm{ft}$ to $123 \mathrm{ft}$ bgs. Ringold Formation silty sandy gravel and sandy gravel occurred from about $123 \mathrm{ft}$ bgs to total depth. A geologist's log is included in Appendix A.

Grab samples of sediment for geologic description and archive were collected at approximate $5 \mathrm{ft}$ intervals throughout the borehole. Also, three split spoon samples were collected from 222.2 to $224.5 \mathrm{ft}$, 237.5 to $239.5 \mathrm{ft}$ and from 252.5 to $254.5 \mathrm{ft}$ bgs for analysis of particle size distribution. The analysis results are in Appendix B. 
Three groundwater samples were collected during drilling. The samples were air lifted slurries of cuttings and water obtained during air rotary drilling. The slurries were filtered using a peristaltic pump and a $0.4-\mu \mathrm{m}$ filter cartridge prior to analysis in the field. The samples were tested for nitrate and specific conductance as a screen for contamination distribution with depth. All analyzed nitrate levels are above the $45 \mathrm{mg} / \mathrm{L}$ maximum contaminant level. The analytical results are shown in Table 3.

The borehole and drill cuttings were monitored regularly for organic vapors and radionuclide contaminants. At 10-ft depth, monitoring showed contamination at 160 decays per minute alpha and 10,000 decays per minute beta. Drilling was temporarily stopped, the borehole labeled as a contamination zone, and the work site labeled as a radiological buffer zone. Contamination decreased to background levels by $21-\mathrm{ft}$ depth and no other contamination was noted.

Table 3. Results of Groundwater Analyses from Samples from New Wells at Waste Management Area TX-TY ${ }^{(a)}$

\begin{tabular}{|c|c|c|c|c|}
\hline Well & $\begin{array}{l}\text { Depth to Water } \\
\text { (ft bgs) }\end{array}$ & $\begin{array}{l}\text { Sample Depth } \\
\text { (ft bgs) }\end{array}$ & Nitrate $(\mathrm{mg} / \mathrm{L})$ & $\begin{array}{l}\text { Specific Conductance } \\
(\mu \mathrm{S} / \mathrm{cm})\end{array}$ \\
\hline \multirow[t]{3}{*}{ 299-W14-15 } & 220.7 & 232 & 64 & $544^{(\mathrm{b})}$ \\
\hline & & 237.5 & 94 & $555^{(\mathrm{b})}$ \\
\hline & & 252.3 & 111 & $570^{(\mathrm{b})}$ \\
\hline \multirow[t]{4}{*}{ 299-W14-16 } & 222 & $232^{(\mathrm{c})}$ & 30 & 304 \\
\hline & & 242 & 46 & 403 \\
\hline & & 252 & 80 & 533 \\
\hline & & 265 & 149 & 680 \\
\hline 299-W14-17 & 222 & 262 & 275 & 680 \\
\hline \multicolumn{5}{|c|}{$\begin{array}{l}\text { (a) Nitrate is } \mathrm{mg} / \mathrm{L} \text { as } \mathrm{NO}_{3}^{-} \text {. Analyzed by } \mathrm{HACH} \text { cadmium reduction method (Method } 8039 \text { ) using a } \\
\mathrm{DR} / 2010 \text { portable spectrophotometer. Reagent blank corrected. } \\
\text { (b) Suspect results. } \\
\text { (c) Water added during drilling iust above the water table mav have diluted results }\end{array}$} \\
\hline
\end{tabular}

\subsection{Well Construction}

The permanent casing and screen were installed in well 299-W14-15 in August 2000. A 4-in.-innerdiameter, stainless steel, continuous wire-wrap (20 slot) screen was set from 254.62 to $219.75 \mathrm{ft}$ bgs. The permanent casing is 4-in.-inner-diameter, stainless steel from $219.75 \mathrm{ft}$ bgs to $2.6 \mathrm{ft}$ above ground surface. A 2-ft-long sump was installed below the screen from 256.7 to $254.6 \mathrm{ft}$.

The filter pack is 10 to 20 mesh silica sand from $260 \mathrm{ft}$ to $290.9 \mathrm{ft}$ bgs. The annular seal is bentonite pellets from $209.9 \mathrm{ft}$ to $199.3 \mathrm{ft}$ bgs, granular bentonite from 199.3 to $13.5 \mathrm{ft}$ bgs, and Portland cement grout from $13.5 \mathrm{ft}$ to the surface. A $4 \mathrm{ft}$ by $4 \mathrm{ft}$ by 6 in. concrete pad was placed around the well at the surface. A protective casing with locking cap, four protective steel posts, and a brass marker stamped with the well number were set into the concrete. The permanent casing extends $1.39 \mathrm{ft}$ above the concrete pad and the protective casing extends $2.48 \mathrm{ft}$ above the concrete pad. The Well Construction Summary Report and the Well Summary Sheet (as-built) are included in Appendix A. 
The vertical and horizontal coordinates of the well were surveyed in March 2001. The horizontal position of the well was determined by Global Positioning System observations referenced to horizontal control stations established by Rogers Surveying, Inc., Richland, Washington, and the U.S. Army Corps of Engineers. The coordinates are Washington Coordinate System, South Zone, NAD83(91) datum. Vertical datum is NAVD 1988 and is based on existing bench marks established by the U.S. Army Corps of Engineers. Survey data are included in Table 2.

\subsection{Well Development and Pump Installation}

Well 299-W14-15 was developed September 5, 2000. A temporary, $3 \mathrm{hp}$, submersible pump was used to remove approximately 2,725 gal of formation water. First, about 1,800 gal of water were removed from the well at $24 \mathrm{gal} / \mathrm{min}$ with a drawdown of about $8.8 \mathrm{ft}$. The pump intake was at $251 \mathrm{ft}$ bgs (4.2 ft above the bottom of the well). Second, about $925 \mathrm{gal}$ of water were removed at $25 \mathrm{gal} / \mathrm{min}$ with the pump intake at $233 \mathrm{ft}$ bgs resulting in $8.6 \mathrm{ft}$ of drawdown. The final turbidity was $3.15 \mathrm{NTU}$.

A dedicated Hydrostar sampling pump was installed in well 299-W14-15 on September 5, 2000. The sampling pump intake is at $220.7 \mathrm{ft}$ bgs (or about $7.1 \mathrm{ft}$ below the water table). Static water level was measured at $220.7 \mathrm{ft}$ bgs on September 5, 2000.

\subsection{Well 299-W14-16}

Well 299-W14-16 was drilled in October and November 2000. The well is located northeast of the TX tank farm.

\subsection{Drilling and Sampling}

To drill this well, an air rotary drill rig was used from the surface to a total depth of $265 \mathrm{ft}$ bgs. Temporary 10 3/4-in.-outside-diameter, carbon steel casing was used from the surface to total depth. An unknown amount of water was added to the borehole above the water table to control dust, help lift cuttings, and unplug the drill bit.

Sediments encountered during drilling were Hanford formation sand, silty sandy gravel and sandy gravel from the surface to about $34 \mathrm{ft}$ bgs and sand from $34 \mathrm{ft}$ to $89 \mathrm{ft}$ bgs. Calcareous sandy silt, and silty sandy gravel the Plio-Pleistocene unit occurred from $89 \mathrm{ft}$ to $122 \mathrm{ft}$ bgs. Ringold Formation silty sandy gravel, sandy gravel, and gravelly sand occurred from about $122 \mathrm{ft}$ bgs to total depth. A geologist's $\log$ is included in Appendix A.

Grab samples of sediment for geologic description and archive were collected at approximate 5-ft intervals throughout the borehole. Also, three split spoon samples were collected from 223.2 to $224.7 \mathrm{ft}$, 241.1 to $244 \mathrm{ft}$, and from 251.0 to $253.5 \mathrm{ft}$ bgs for analysis of particle size distribution. The analysis results are in Appendix B. 
Four groundwater samples were collected during drilling. The samples were air lifted slurries of cuttings and water obtained during air rotary drilling. The slurries were filtered using a peristaltic pump and a $0.4-\mu \mathrm{m}$ filter cartridge prior to analysis in the field. The samples were tested for nitrate and specific conductance as a screen for contamination distribution with depth. Except for the shallowest sample at 232-ft depth, all analyzed nitrate levels are above the $45 \mathrm{mg} / \mathrm{L}$ maximum contaminant level. Water was added to the borehole at $232 \mathrm{ft}$ bgs so that the sample may have been diluted. The analytical results are shown in Table 3.

The borehole and drill cuttings were monitored regularly for organic vapors and radionuclide contaminants. No contaminants were noted.

The well was geophysically logged through the temporary casing using high resolution, spectral gamma-ray and neutron moisture instrumentation on November 1 and 2, 2000. No manmade radionuclides were detected. The geophysical logs are in Appendix B.

\subsection{Well Construction}

The permanent casing and screen were installed in well 299-W14-16 in November 2000. A 4-in.inner-diameter, stainless steel, continuous wire-wrap (0.02 in. slot) screen was set from 257.88 to $222.94 \mathrm{ft}$ bgs. The permanent casing is 4-in.-inner-diameter, stainless steel from $222.94 \mathrm{ft}$ bgs to $2.0 \mathrm{ft}$ above ground surface. A 2-ft-long, stainless steel sump is below the screen from 260.06 to $257.88 \mathrm{ft}$ bgs.

The filter pack is 10 to 20 mesh silica sand from 265.0 to $210.4 \mathrm{ft}$ bgs. The annular seal is $1 / 4 \mathrm{in}$. bentonite pellets from 210.4 to $204.5 \mathrm{ft}$ bgs; granular bentonite from 204.5 to $11.3 \mathrm{ft} \mathrm{bgs}$; and Portland cement from $11.3 \mathrm{ft}$ bgs to the surface. A $4 \mathrm{ft}$ by $4 \mathrm{ft}$ by $6 \mathrm{in}$. concrete pad was placed around the well at the surface. A protective casing with locking cap, four protective steel posts, and a brass marker stamped with the well number were set into the concrete. The permanent casing extends $1.46 \mathrm{ft}$ above the concrete pad and the protective casing extends $2.46 \mathrm{ft}$ above the concrete pad. The Well Construction Summary Report and the Well Summary Sheet (as-built) are included in Appendix A.

The vertical and horizontal coordinates of the well were surveyed in March 2001. The horizontal position of the well was determined by Global Positioning System observations referenced to horizontal control stations established by Rogers Surveying, Inc., Richland, Washington, and the U.S. Army Corps of Engineers. The coordinates are Washington Coordinate System, South Zone, NAD83(91) datum. Vertical datum is NAVD 1988 and is based on existing bench marks established by the U.S. Army Corps of Engineers. Survey data are included in Table 2.

\subsection{Well Development and Pump Installation}

Well 299-W14-16 was developed on November 22 and November 27, 2000. A temporary, $3 \mathrm{hp}$, submersible pump was used to remove approximately 5,180 gal of formation water from the well. First, about 4,775 gal of water were removed from the well at $24 \mathrm{gal} / \mathrm{min}$ with a drawdown of about $14.7 \mathrm{ft}$. The pump intake was at $257 \mathrm{ft}$ bgs ( $1.3 \mathrm{ft}$ above the bottom of the screen). Second, about 405 gallons of water were removed at $24 \mathrm{gal} / \mathrm{min}$ with the pump intake at $237 \mathrm{ft}$ bgs. The final turbidity was $3.16 \mathrm{NTU}$. 
A dedicated, Redi Flo2 submersible sampling pump was installed in well 299-W11-16 on December 22,2000 . The sampling pump intake is at $232.9 \mathrm{ft}$ bgs (or about $9.5 \mathrm{ft}$ below the water table). Water level was measured at $223.4 \mathrm{ft}$ bgs on December 22, 2000.

\subsection{Well 299-W14-17}

Well 299-W14-17 was drilled in October 2000. The well is located east of TX tank farm.

\subsection{Drilling and Sampling}

The well was drilled from the surface to $20.6 \mathrm{ft}$ bgs with a cable tool rig and drive barrel and from $20.6 \mathrm{ft}$ to a total depth of $265.3 \mathrm{ft}$ bgs with an air rotary rig. Temporary $113 / 4$-in.-outside-diameter, carbon steel casing was placed from 0 to $20.6 \mathrm{ft}$ bgs and temporary $85 / 8$-in.-outside-diameter carbon steel casing from $20.6 \mathrm{ft}$ to $265.3 \mathrm{ft}$ bgs. An unknown amount of water was added to the drilling air stream at 185 -ft depth for dust control.

Sediments encountered during drilling were Hanford formation gravelly sand, silty sandy gravel, and sandy gravel from the surface to about $34 \mathrm{ft}$ bgs and sand from $34 \mathrm{ft}$ to $93 \mathrm{ft}$ bgs. Calcareous silty sand, gravelly silty sand, and silty sandy gravel of the Plio-Pleistocene unit occurred from $93 \mathrm{ft}$ to $113 \mathrm{ft}$ bgs. Sand, probably belonging to the Ringold Formation member of Taylor Flat, occurred from $113 \mathrm{ft}$ to $122 \mathrm{ft}$ bgs and Ringold Formation member of Wooded Island sandy gravel, silty sandy gravel, and gravelly sand occurred from about $122 \mathrm{ft}$ bgs to total depth. A geologist's log is included in Appendix A.

Grab samples of sediment for geologic description and archive were collected at approximate 5-ft intervals throughout the borehole. Also, three split spoon samples were collected from 228 to $228.75 \mathrm{ft}$, 244.9 to $246.4 \mathrm{ft}$, and from 255.4 to $257.9 \mathrm{ft}$ bgs for analysis of particle size distribution. The analysis results are in Appendix B.

One groundwater sample was collected during drilling. The sample was an air lifted slurry of cuttings and water obtained during air rotary drilling. The slurry was filtered using a peristaltic pump and a $0.4-\mu \mathrm{m}$ filter cartridge prior to analysis in the field. The sample was tested for nitrate and specific conductance as a screen for contamination distribution with depth. The nitrate level was above the $45 \mathrm{mg} / \mathrm{L}$ maximum contaminant level. The analytical results are shown in Table 3.

The borehole and drill cuttings were monitored regularly for organic vapors and radionuclide contaminants. No contaminants were noted.

The well was geophysically logged through the temporary casing using high resolution, spectral gamma-ray and neutron moisture instrumentation on October 17, 2001. No manmade radionuclides were detected. The geophysical logs are in Appendix C. 


\subsection{Well Construction}

The permanent casing and screen were installed in well 299-W14-17 in October 2001. A 4-in.-innerdiameter, stainless steel, continuous wire-wrap (0.02 in. slot) screen was set from 256.96 to $221.94 \mathrm{ft}$ bgs. The permanent casing is 4-in.-inner-diameter, stainless steel from $221.94 \mathrm{ft}$ bgs to $2.58 \mathrm{ft}$ above ground surface. The bottom of the screen has a 2-ft-long sump from 259.01 to $256.6 \mathrm{ft}$ bgs.

The filter pack is 10 to 20 mesh silica sand from 265.5 to $211.9 \mathrm{ft}$ bgs. The annular seal is $3 / 8$-in. bentonite pellets from 211.9 to $204.7 \mathrm{ft}$ bgs; granular bentonite from 204.7 to $10.6 \mathrm{ft}$ bgs; and Portland cement from $10.6 \mathrm{ft}$ to the surface. A $4 \mathrm{ft}$ by $4 \mathrm{ft}$ by 6 in. concrete pad was placed around the well at the surface. A protective casing with locking cap, four protective steel posts, and a brass marker stamped with the well number were set into the concrete. The permanent casing extends $1.83 \mathrm{ft}$ above the concrete pad and the protective casing extends $2.58 \mathrm{ft}$ above the concrete pad.

A straightness test on October 18, 2001, using a $20 \mathrm{ft}$ section of 6-5/8-outer-diameter stainless casing was unsuccessful at $170 \mathrm{ft}$ bgs. This corresponds to the depth $(173 \mathrm{ft})$ at which a probable boulder was encountered during drilling. A camera survey showed that the casing appeared solid and all joints were intact. A second straightness test using a $21 \mathrm{ft}$ piece of 5 5/8-in.-outside-diameter pipe was successful.

The Well Construction Summary Report and the Well Summary Sheet (as-built) are included in Appendix A.

The vertical and horizontal coordinates of the well were surveyed in March 2001. The horizontal position of the well was determined by Global Positioning System observations referenced to horizontal control stations established by Rogers Surveying, Inc., Richland, Washington, and the U.S. Army Corps of Engineers. The coordinates are Washington Coordinate System, South Zone, NAD83(91) datum. Vertical datum is NAVD 1988 and is based on existing bench marks established by the U.S. Army Corps of Engineers. Survey data are included in Table 2.

\subsection{Well Development and Pump Installation}

Well 299-W14-17 was developed on November 27, 2000. A temporary, submersible pump was used to remove approximately 2,050 gal of formation water from the well. First, about $897 \mathrm{gal}$ of water were removed from the well at $23 \mathrm{gal} / \mathrm{min}$ with a drawdown of about $8.8 \mathrm{ft}$. The depth of the pump intake is not documented. Second, about 1,160 gal of water were removed at 20 and $17 \mathrm{gal} / \mathrm{min}$ with a drawdown of $8.2 \mathrm{ft}$. The final turbidity was $1.81 \mathrm{NTU}$.

A dedicated, Redi Flo2 submersible sampling pump was installed in well 299-W14-17 on December 27, 2000. The sampling pump intake is about $10 \mathrm{ft}$ below the water table. The water level was measured at $222.7 \mathrm{ft}$ bgs on December 27, 2000. 


\subsection{Well 299-W15-763}

Well 299-W15-763 was drilled from November 2000 through January 2001 using a cable tool drill rig. The well is located south of the TX tank farm.

\subsection{Drilling and Sampling}

Temporary 11 3/4-in.-outside-diameter, carbon steel casing was placed from 0 to $134.2 \mathrm{ft}$. below ground surface (bgs) and 8 5/8-in.-outside-diameter carbon steel casing was placed from 134.2 to $252.6 \mathrm{ft}$ bgs. The borehole was advanced with drive barrel from the surface to $134.2 \mathrm{ft}$ depth and by hard tool from $134.2 \mathrm{ft}$ to a total depth of $257.6 \mathrm{ft}$. Approximately 430 gal of water were added to the borehole during hard tool drilling.

Sediments encountered during drilling were predominantly gravelly sand, sandy gravel, and silty sandy gravel of the Hanford formation from the surface to about $94 \mathrm{ft}$ bgs. Plio-Pliestocene silt and silty sand was encountered from $94 \mathrm{ft}$ to $101.5 \mathrm{ft}$ and Plio-Pleistocene gravelly silty sand with caliche was found from $101.5 \mathrm{ft}$ to $117 \mathrm{ft}$ bgs. Ringold Formation silty sandy gravel with lesser amounts of sandy gravel and gravelly silty sand occurred from $117 \mathrm{ft}$ to total depth $(257.6 \mathrm{ft})$. A geologist's log is included in Appendix A.

Grab samples of sediment for geologic description and archive were collected at approximate 5-ft intervals from $20 \mathrm{ft}$ to total depth. Three split spoon samples were collected from 217 to $219 \mathrm{ft}, 232$ to $234 \mathrm{ft}$ and from 245 to $247 \mathrm{ft}$ bgs for analysis of particle size distribution. Particle size distribution data is in Appendix C.

The borehole and drill cuttings were monitored regularly for organic vapors and radionuclide contaminants. No contamination was found.

\subsection{Well Construction}

The permanent casing and screen were installed in well 299-W15-763 in January 2001. A 4-in.inner-diameter, stainless steel, continuous wire-wrap (0.02 in. slot) screen was set from 246.82 to $211.75 \mathrm{ft}$ bgs. The permanent casing is 4-in.-inner-diameter, stainless steel from $211.75 \mathrm{ft}$ bgs to $2.0 \mathrm{ft}$ above ground surface. A 2-ft stainless steel sump was placed at the bottom of the screen from 248.82 to $246.82 \mathrm{ft}$ bgs.

The sand pack is 10 to 20 mesh silica sand from 257.6 to $202.4 \mathrm{ft}$ bgs. The annular seal is bentonite pellets from 202.4 to $191.1 \mathrm{ft}$ bgs, granular bentonite from 191.1 to $9.2 \mathrm{ft}$ bgs, and Portland cement with bentonite from $9.2 \mathrm{ft}$ depth to the surface. A $4 \mathrm{ft}$ by $4 \mathrm{ft}$ by 6 in. concrete pad was placed around the well at the surface. A 6-in. stainless steel protective casing with locking cap, four protective steel posts, and a brass marker stamped with the well number were set into the concrete. The protective casing extends 
$2.56 \mathrm{ft}$ above the concrete pad and the inner casing extends $1.54 \mathrm{ft}$ above the concrete pad. The Well Construction Summary Report and the Well Summary Sheet (as-built) are included in Appendix A.

The vertical and horizontal coordinates of the well were surveyed in May 2001. The horizontal position of the well was determined by Global Positioning System observations referenced to horizontal control stations established by Rogers Surveying, Inc., Richland, Washington, and the U.S. Army Corps of Engineers. The coordinates are Washington Coordinate System, South Zone, NAD83(91) datum. Vertical datum is NAVD 1988 and is based on existing bench marks established by the U.S. Army Corps of Engineers. Survey data are included in Table 2.

\subsection{Well Development and Pump Installation}

Well 299-W15-763 was developed on March 26 through March 28, 2001. A temporary, 3 hp, submersible pump was used to remove approximately 3,613 gal of formation water from the well. First, 2,294 gal were pumped at 5 to $6 \mathrm{gal} / \mathrm{min}$ with the pump set at $239.8 \mathrm{ft} \mathrm{bgs}$; drawdown was $22.5 \mathrm{ft}$. Second, about $1,319 \mathrm{gal}$ were pumped at $4.8 \mathrm{gal} / \mathrm{min}$ with the pump at $227.8 \mathrm{ft}$ bgs. Final drawdown was $3.2 \mathrm{ft}$. The final turbidity was 4.98 NTU.

A dedicated, Redi Flo2 submersible sampling pump was installed in well 299-W15-763 on March 29, 2001. The sampling pump intake is at $227.8 \mathrm{ft}$ bgs (or about $13.3 \mathrm{ft}$ below the water table). The static water level was $214.97 \mathrm{ft}$ bgs on March 29, 2001.

\subsection{References}

Caggiano, J. A., and C. J. Chou. 1993. Interim-Status Groundwater Quality Assessment Plan for the Single Shell Tank Waste Management Areas T and TX-TY. WHC-SD-EN-AP-132, Rev. 0, Westinghouse Hanford Company, Richland, Washington.

Ecology - Washington State Department of Ecology, U.S. Environmental Protection Agency, and U.S. Department of Energy. 1998. Hanford Federal Facility Agreement and Consent Order. Document No. 89-10, Rev. 5 (The Tri-Party Agreement), Olympia, Washington.

Hodges, F. N., and C. J. Chou. 2001. RCRA Assessment Plan for Single-Shell Tank Waste Management Area TX-TY at the Hanford Site. PNNL-12072, Pacific Northwest National Laboratory, Richland, Washington.

RCRA - Resource Conservation and Recovery Act. 1976. Public Law 94-580, as amended, 90 Stat. 2795, 42 USC 6901 et seq. 
WAC 173-160, Washington Administrative Code. Minimum Standards for Construction and Maintenance of Wells. Olympia, Washington.

WAC 173-303, Washington Administrative Code. Dangerous Waste Regulations. Olympia, Washington. 
Appendix A

Well Construction and Completion Documentation 


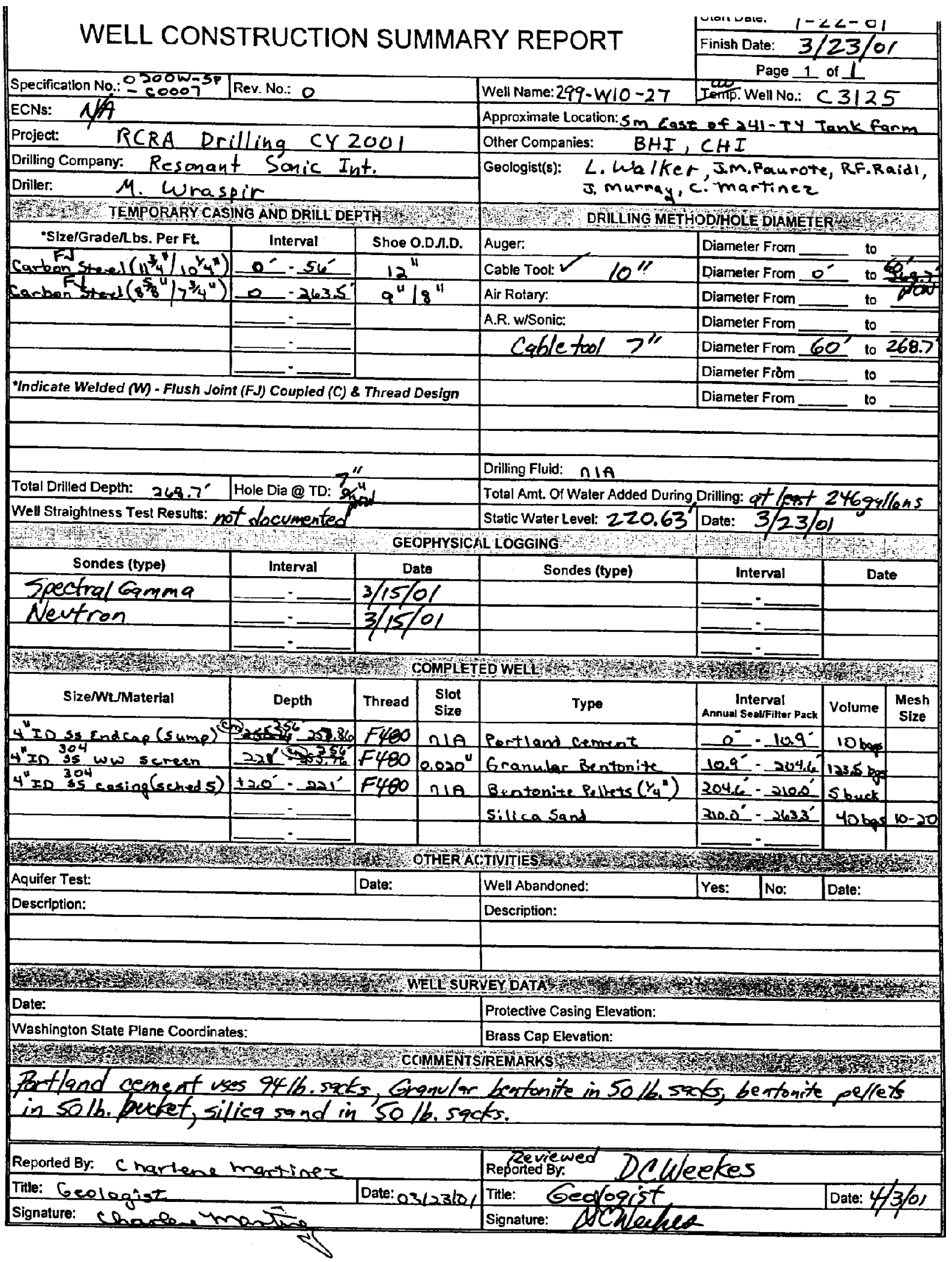

BHI-EE-181 (12/97) 


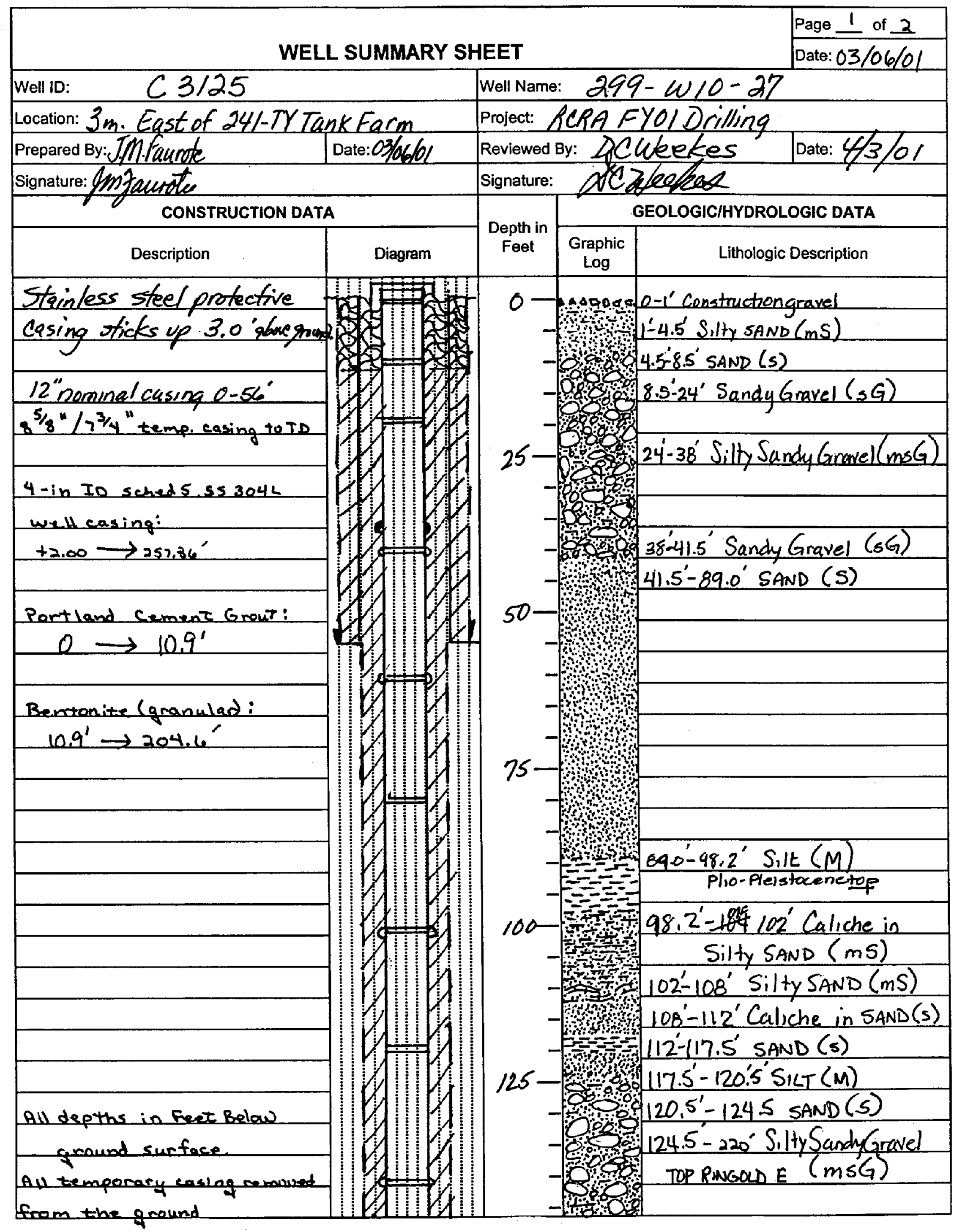

BHI-EE-189 (12/97) 


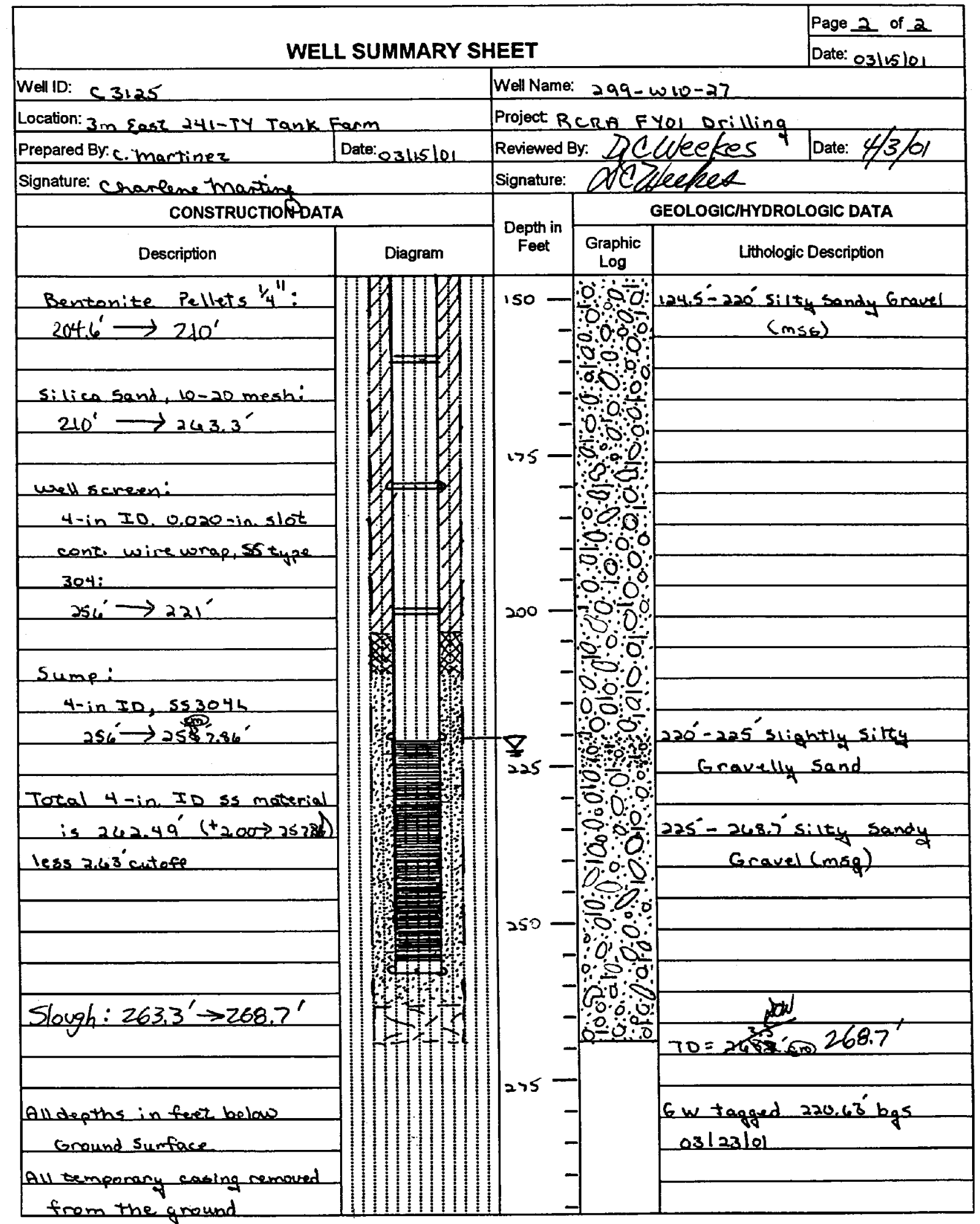

BHI-EE-189 (12/97) 


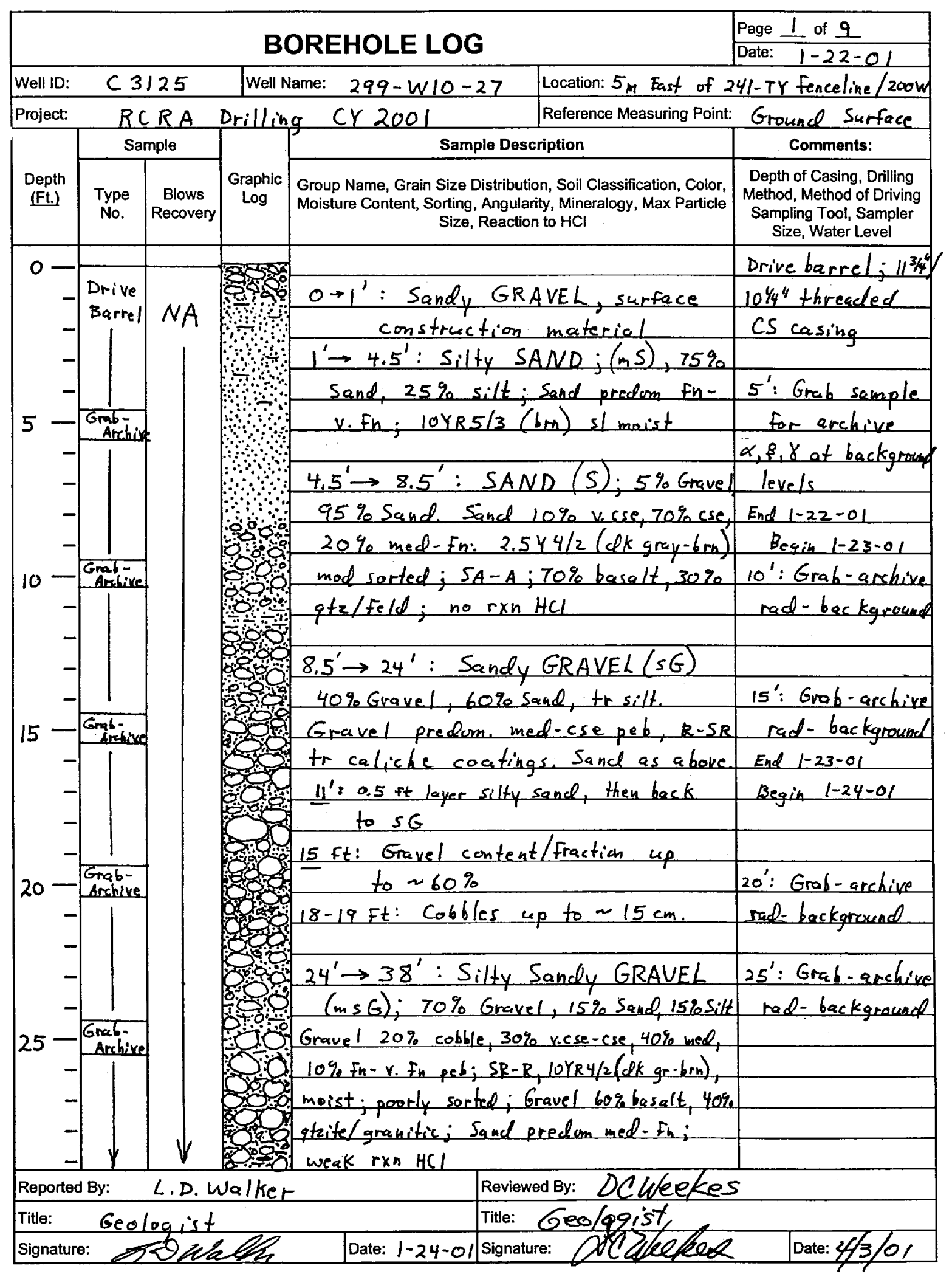

8HI-EE-183 (12/97) 


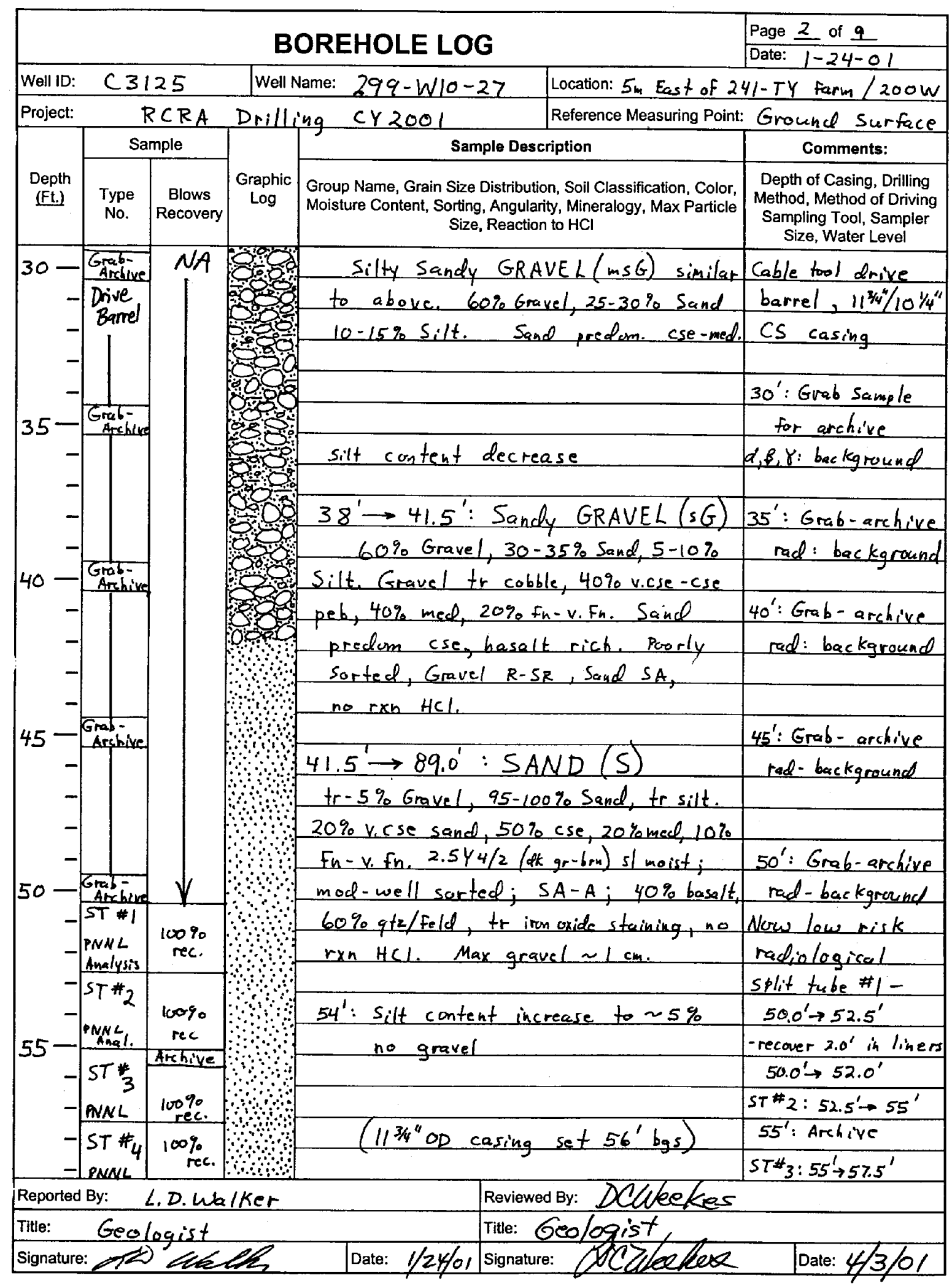

BHI-EE-183 (12/97) 


\begin{tabular}{|c|c|c|c|c|c|c|}
\hline \multirow{2}{*}{\multicolumn{6}{|c|}{ BOREHOLE LOG }} & \multirow{2}{*}{ Page $\frac{3}{1-24-01}$} \\
\hline & & & & & & \\
\hline Well ID: & \multicolumn{2}{|c|}{$C 3125$} & \multicolumn{2}{|c|}{ Well Name: $299-$ W $10-27$} & \multicolumn{2}{|c|}{ Location: $5 \mathrm{~m}$ east of $241-T Y$ farm/200W } \\
\hline Project: & \multicolumn{2}{|c|}{$R \subset R A$} & \multirow{2}{*}{\multicolumn{3}{|c|}{$\frac{\text { CY } 2001}{\text { Sample Description }}$}} & Ground Surface \\
\hline \multirow[b]{2}{*}{$\begin{array}{c}\text { Depth } \\
\text { (Ft.) }\end{array}$} & & mple & & & & Comments: \\
\hline & $\begin{array}{l}\text { Type } \\
\text { No. }\end{array}$ & $\begin{array}{c}\text { Blows } \\
\text { Recovery }\end{array}$ & $\begin{array}{c}\text { Graphic } \\
\text { Log }\end{array}$ & \multicolumn{2}{|c|}{$\begin{array}{l}\text { Group Name, Grain Size Distribution, Soil Classification, Color, } \\
\text { Moisture Content, Sorting, Angularity, Mineralogy, Max Particle } \\
\text { Size, Reaction to HCl }\end{array}$} & $\begin{array}{c}\text { Depth of Casing, Drilling } \\
\text { Method, Method of Driving } \\
\text { Sampling Tool, Sampler } \\
\text { Size, Water Level }\end{array}$ \\
\hline $60-$ & Archive & & \multirow{3}{*}{ and } & \multicolumn{2}{|r|}{$S T^{1 / 4} / \cdot 57.5 \cdot 60^{\prime}$} & 5"OD split tube \\
\hline \multirow{2}{*}{-} & $\begin{array}{l}\text { SPLAT } \\
\text { SPOON }\end{array}$ & & & \multicolumn{2}{|c|}{ v. sporadic sm. gcavel, $e</ \mathrm{cm}$ size. } & Sampler, for PNNL \\
\hline & $\begin{array}{l}\# 5 \\
\text { PNNL }\end{array}$ & $\begin{array}{l}100 \% \\
\text { rec. }\end{array}$ & & \multicolumn{2}{|c|}{ m-ergend 60-6i, e 61 became f $m$ grnd } & analysis / archive \\
\hline & \multirow{3}{*}{$\begin{array}{l}S T^{*} 6 \\
\text { PNNL } \\
\text { Analysis }\end{array}$} & \multirow{3}{*}{\multicolumn{2}{|c|}{$\begin{array}{l}100 \% \\
\text { Archive }\end{array}$}} & & & $5 T^{H} 5: 60 .-62.5^{\circ}$ \\
\hline & & & & & & 65'Archive \\
\hline \multirow{2}{*}{$65-$} & & & & upterfingered cea & arse sand lenses inother- & $5 T+6: 62.5-65.0$ \\
\hline & \multirow{2}{*}{$\begin{array}{l}S T \# 7 \\
\text { PNNL } \\
\text { AONASTS }\end{array}$} & \multirow{2}{*}{$100 \%$} & \multirow{2}{*}{ (nis } & \multicolumn{2}{|c|}{ wereringered cearse sand lebses inemer- } & \\
\hline & & & & $S R$ grnd, dry san & nd wo trace to mener & $5 T \div 7: 65^{\prime}-67.5^{\prime}$ \\
\hline & $s T \neq \theta$ & & 10 & amounts of sult. & The unit is cot besen & \\
\hline & PNNL & recovery & 40 & & & $58.675-70^{\prime}$ \\
\hline & Analpes & Archive & & & & Archive grab samplet \\
\hline & $57^{\text {Hq }}$ & & 5 & & & $5 x^{\circ} 9\left(70^{\circ} 725^{\prime}\right)$ \\
\hline & $\begin{array}{l}\text { PNNL } \\
\text { Analysis } \\
\end{array}$ & $100 \%$ & 60 & Whitish-gra & as comont? (carbonate) & \\
\hline- & $5 \% * 10$ & & & stanted e z2bs & 25. Sand is now & $5 \times 10\left(72.5^{\prime}: 75^{\prime}\right)$ \\
\hline & park & $100 \%$ & 6 & $1 t$-medgy $r f-\nu$ & ver grnd, extibits & Archive $75^{\prime}$ sample \\
\hline 75 & & Archire & Wh & k. $5 \mathrm{~m}$. sporadic th & Gematite spots $(1-2 \mathrm{~mm})$ & \\
\hline & $57 \%$ & & 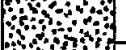 & & & $5 \pi \geqslant\left(75-77^{\circ}\right)$ \\
\hline & PNoll & $100 \%$ & (3) & increasing heme & atite, sporadic mica, & \\
\hline- & $s J^{*} / 2$ & & & contenues $S A-S R, C$ & dys furrsand w/ mued & \\
\hline & PNWL. & $100 \%$ & & 1t-mode Cac & Cos cement. & $5 T^{*} / 2\left(77.5 .80^{\circ}\right)$ \\
\hline & Anaksis & Arehise & 6 & & & Archive 80 'Sample. \\
\hline & $\begin{array}{l}-13 \\
\text { SNNL }\end{array} \mid$ & $100 \%$ & 6 & & & \\
\hline & Anatures & & 6 & & & $50 / 3(50-82.5)$ \\
\hline & STम/4 & & 18 & & & \\
\hline & PNNL & $100 \%$ & & & & $J T / 4(82.585 .0)$ \\
\hline 85 & Analusis & Archive & Hin & & & Archue 55 sampe \\
\hline & $5 T 2 / 5$ & $100 \%$ & W & & & START I MAR OI RFI \\
\hline & $\begin{array}{l}\text { PNNL } \\
\text { Analys/s }\end{array}$ & $e^{2}$ & 4 & & & $5775<85 \theta-87.5$ \\
\hline & ST \& & $100 \%$ & his & 89.0 SILT LAYE & & Archine 90'sample \\
\hline-1 & & archive & ing & & & $5 T 16 \quad 87.5-90$ \\
\hline Reported & By: T/m & Dfauro & & & Reviewed By: DClleekes & \\
\hline Title: $\mathrm{GS}_{4}$ & ologes & & & & Title: Geoforist & \\
\hline Signature & $\operatorname{lng}$ za & wats & & Date: & Signature: DrTeafeen & Date: $4 / 3 / 01$ \\
\hline
\end{tabular}




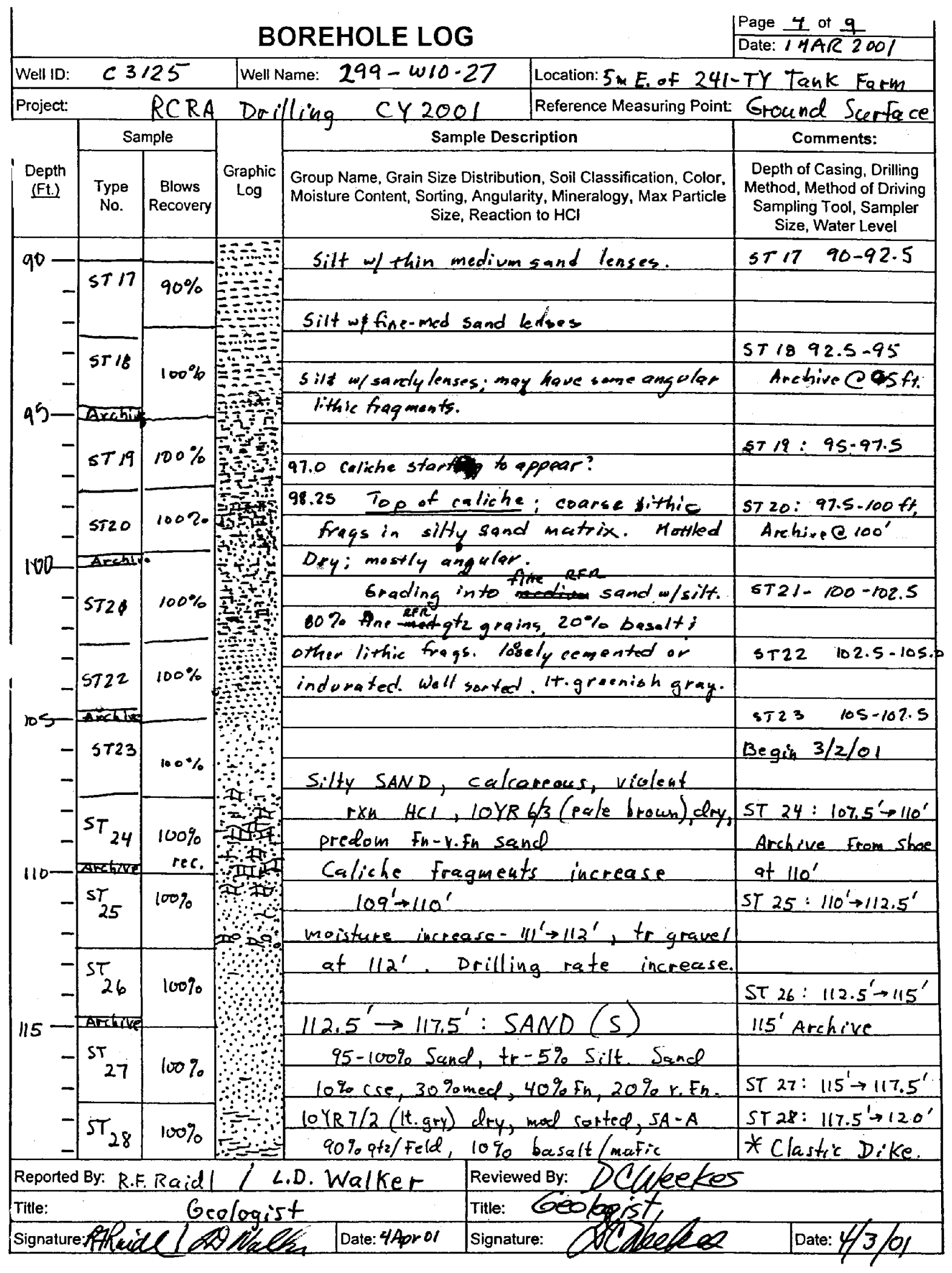

BHI-EE-183 (12/97) 


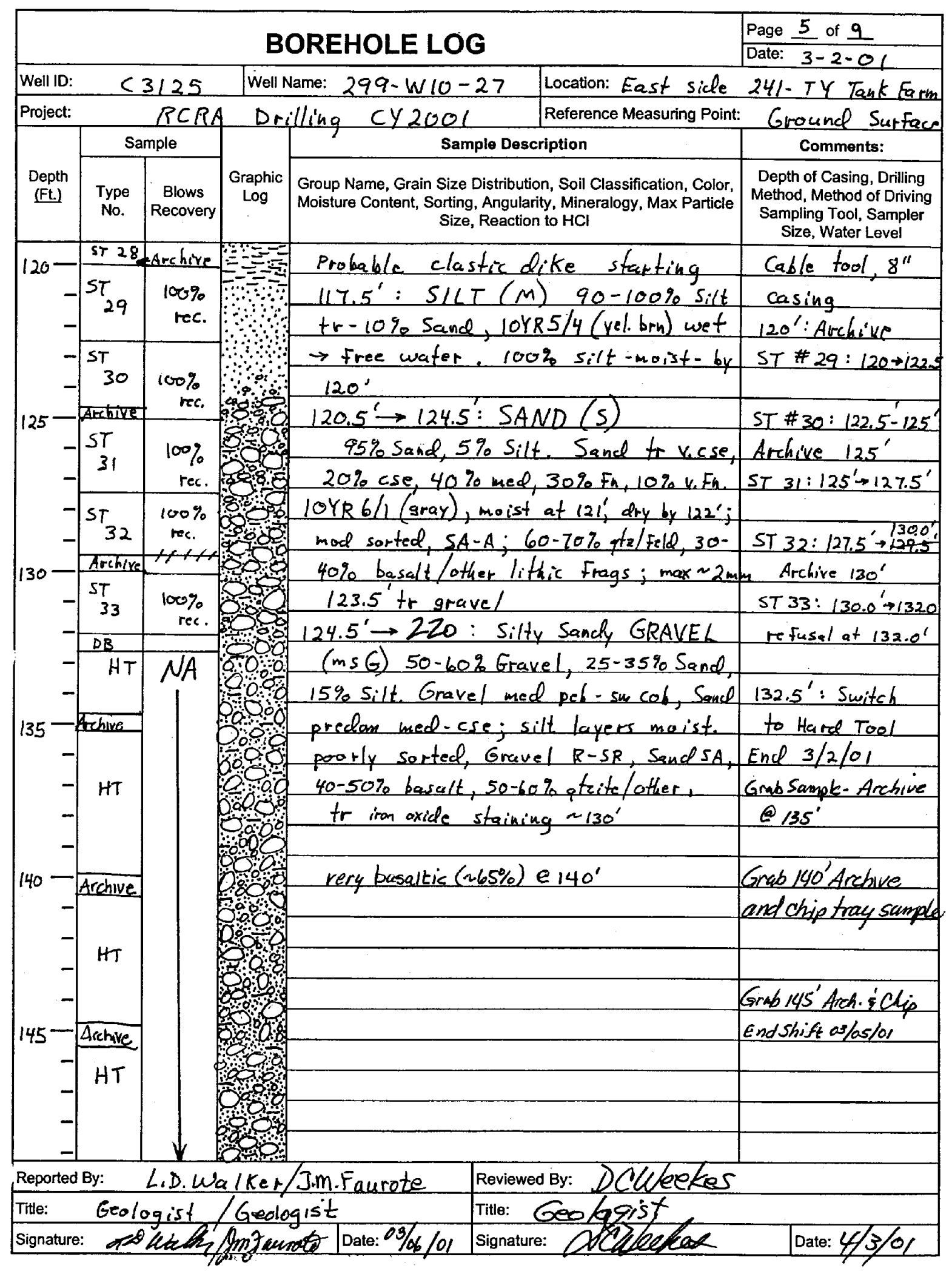

BHI-EE-183 (12/97; 


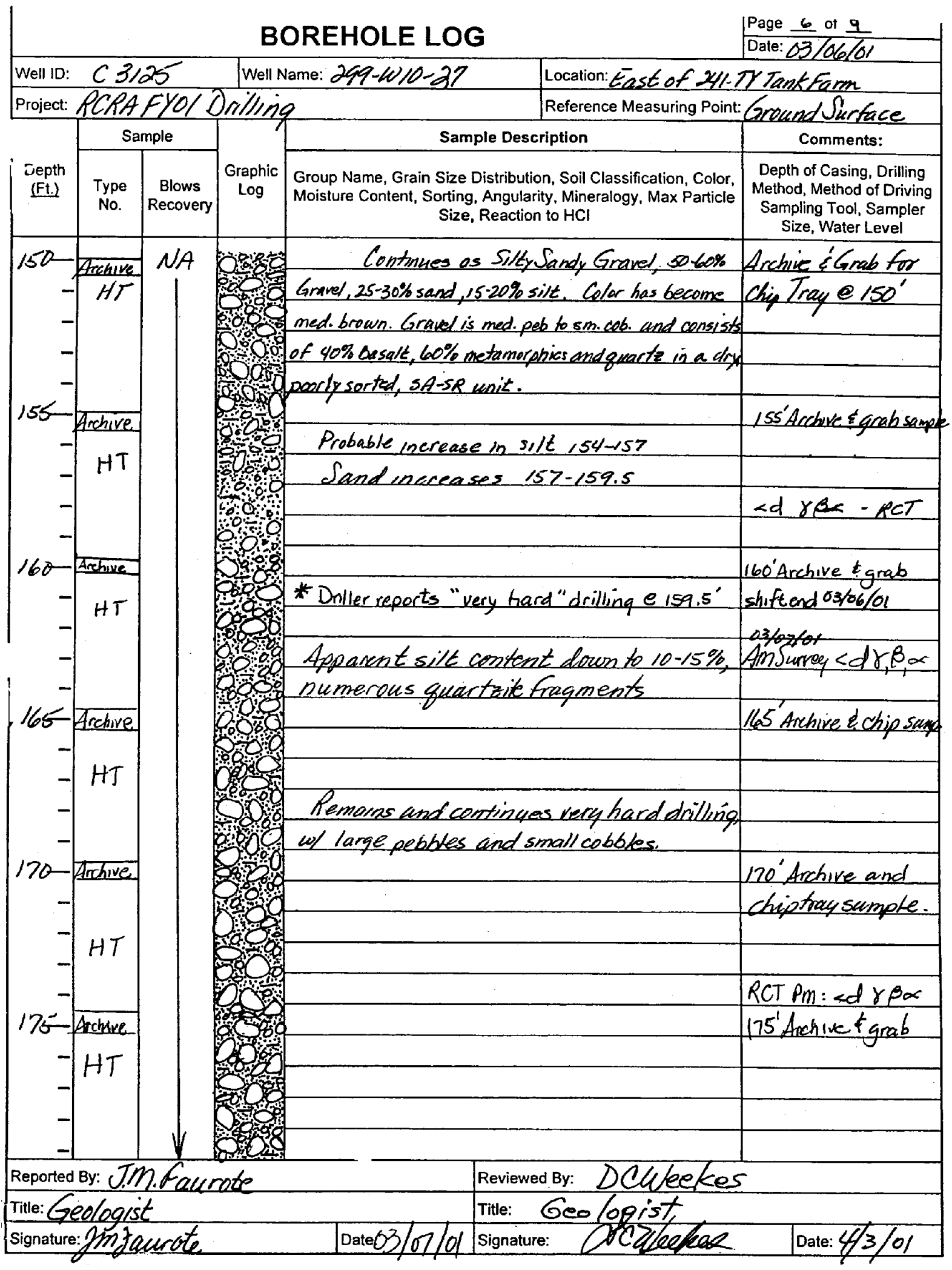

BHI-EE-183 (12/97) 


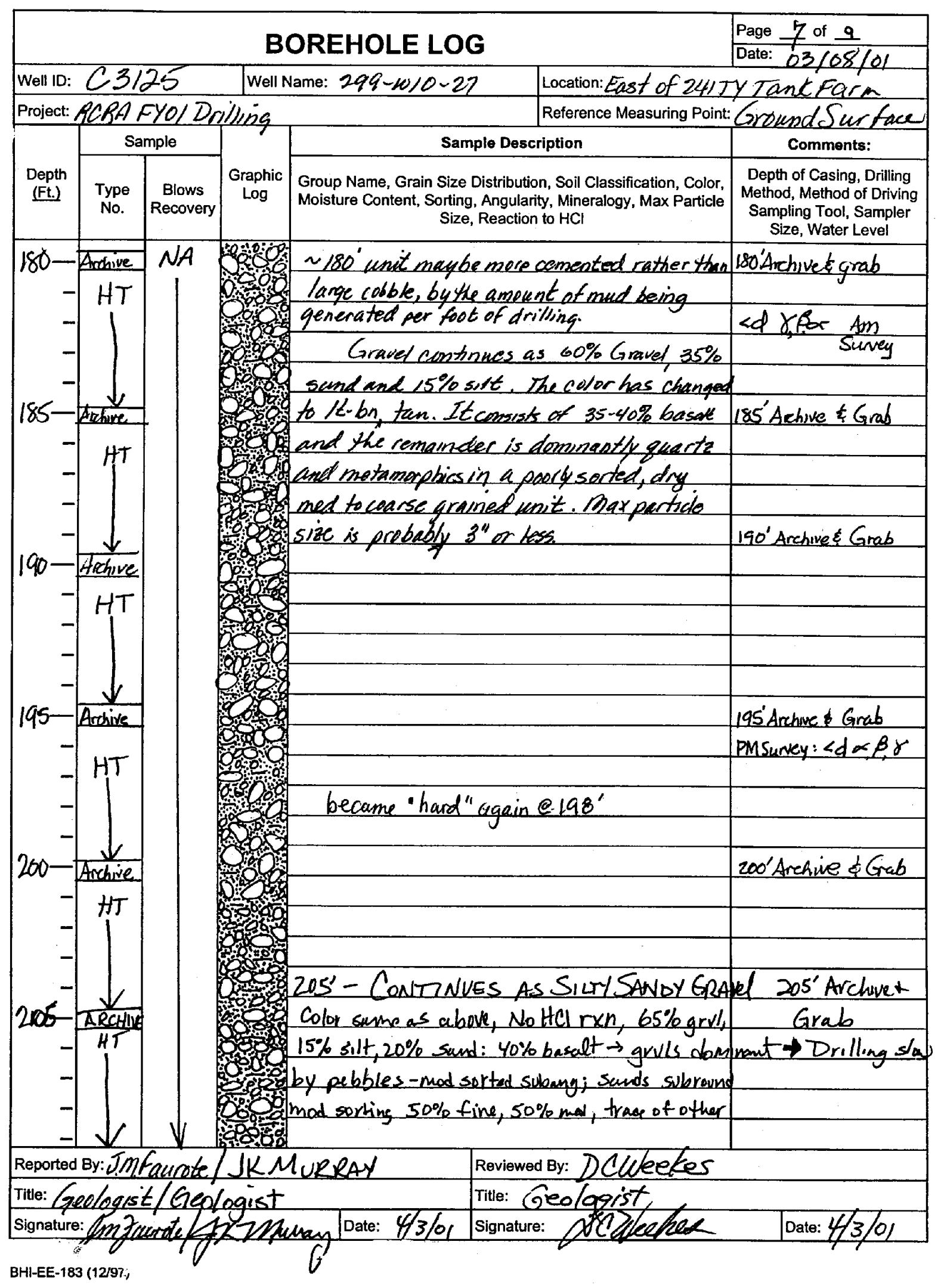




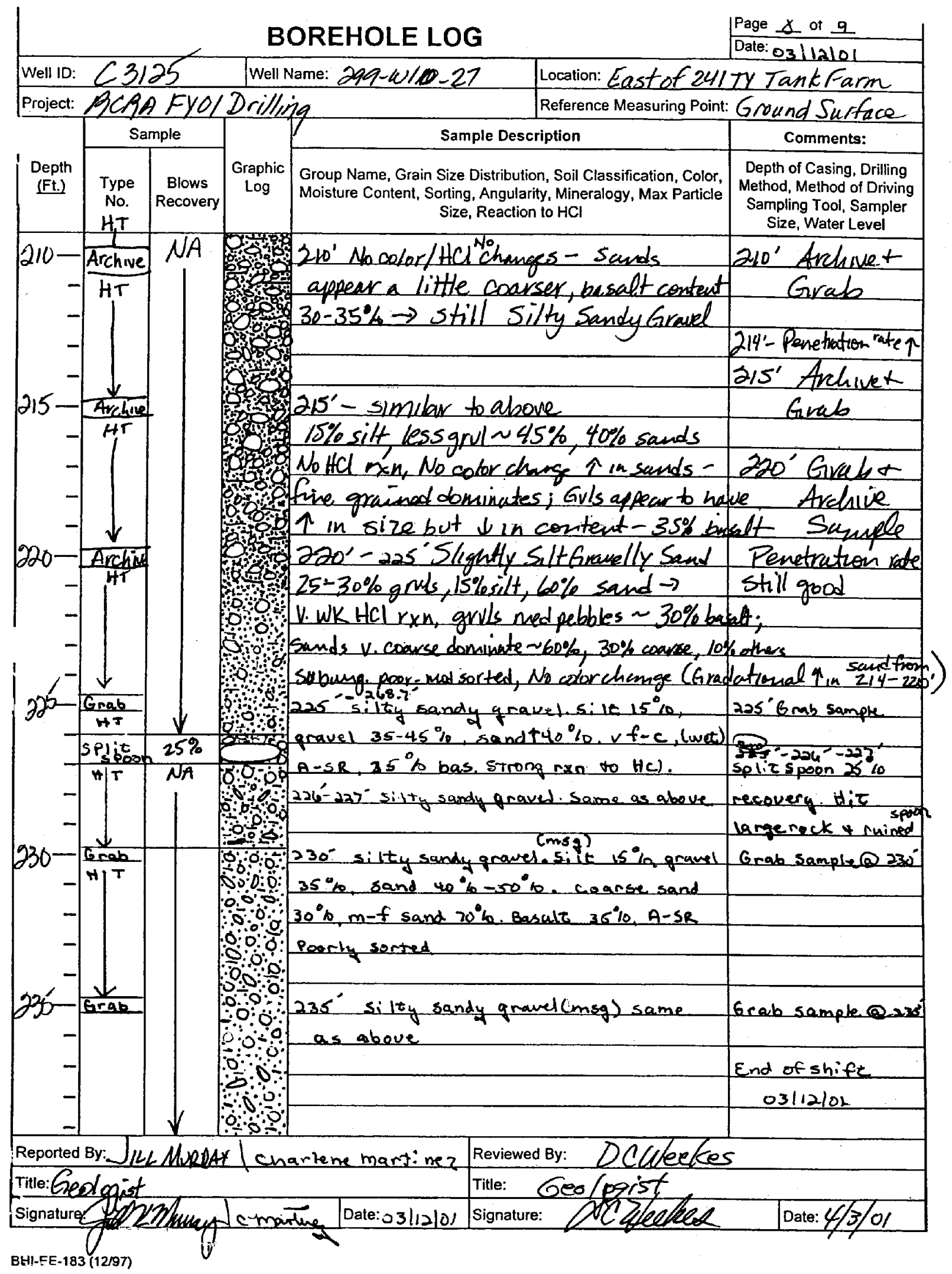

A. 11 


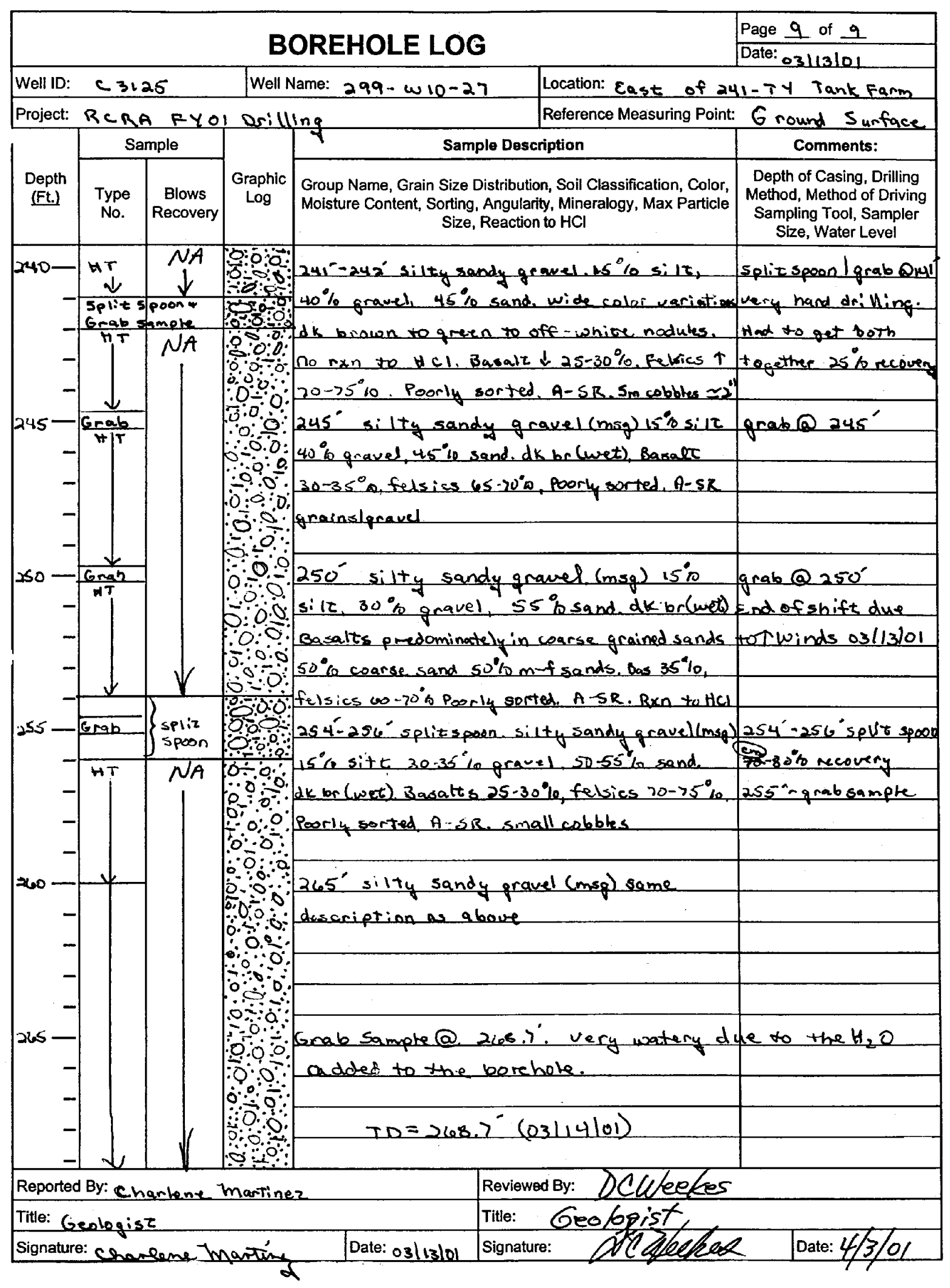

BHI-EE-185 (1यII) 


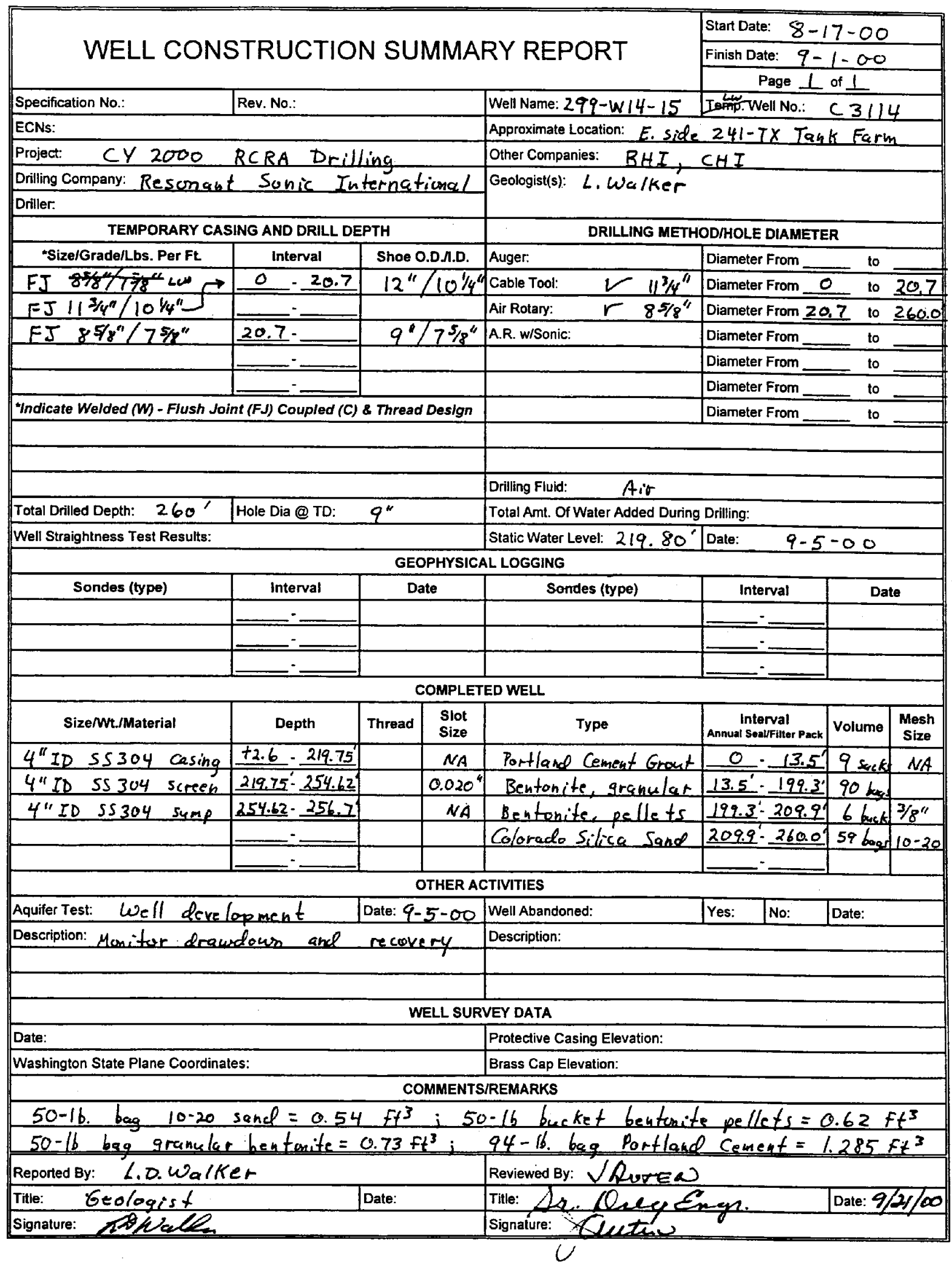

BHI-EE-181 (12/97) 


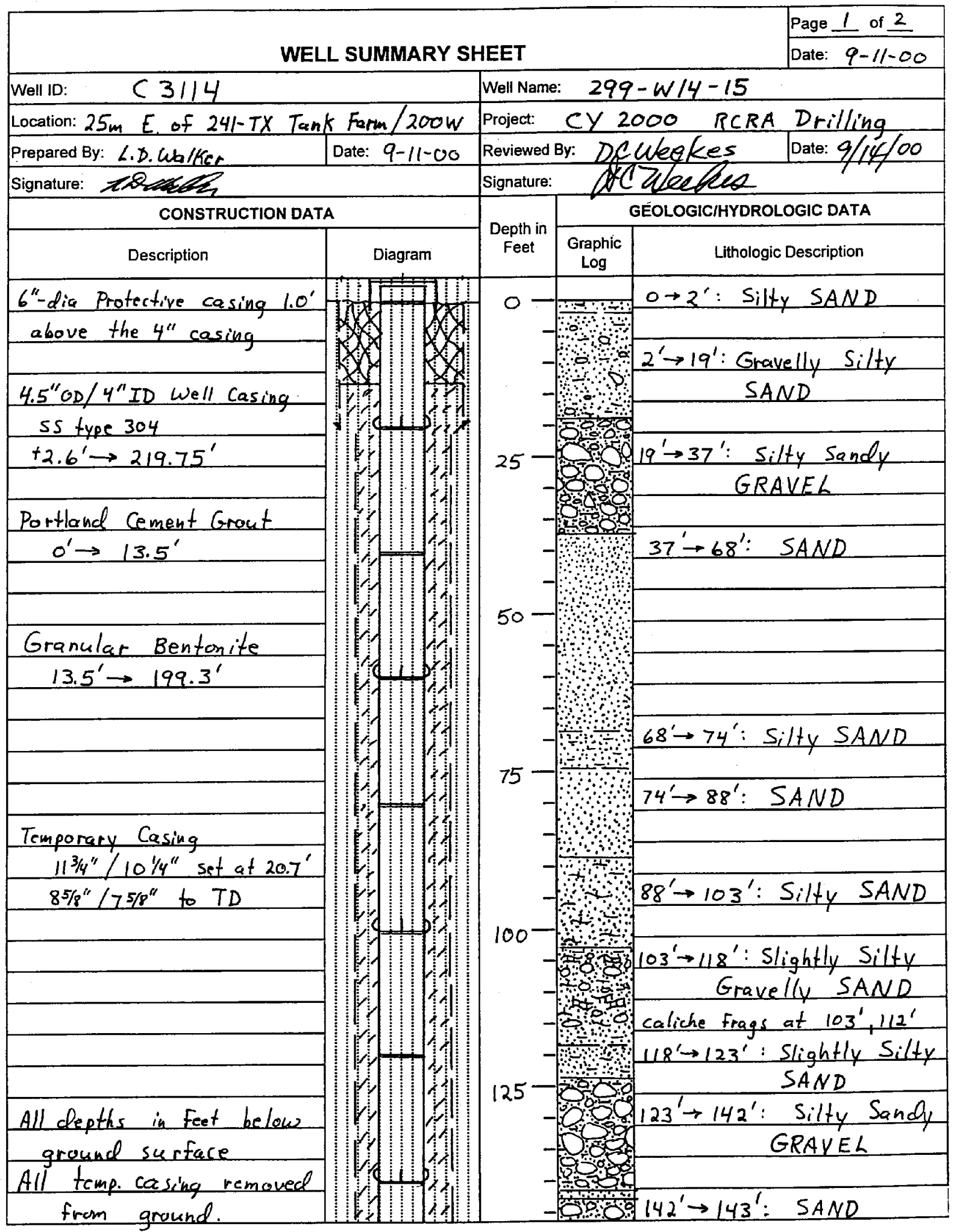

BHI-EE-189 (12/97) 


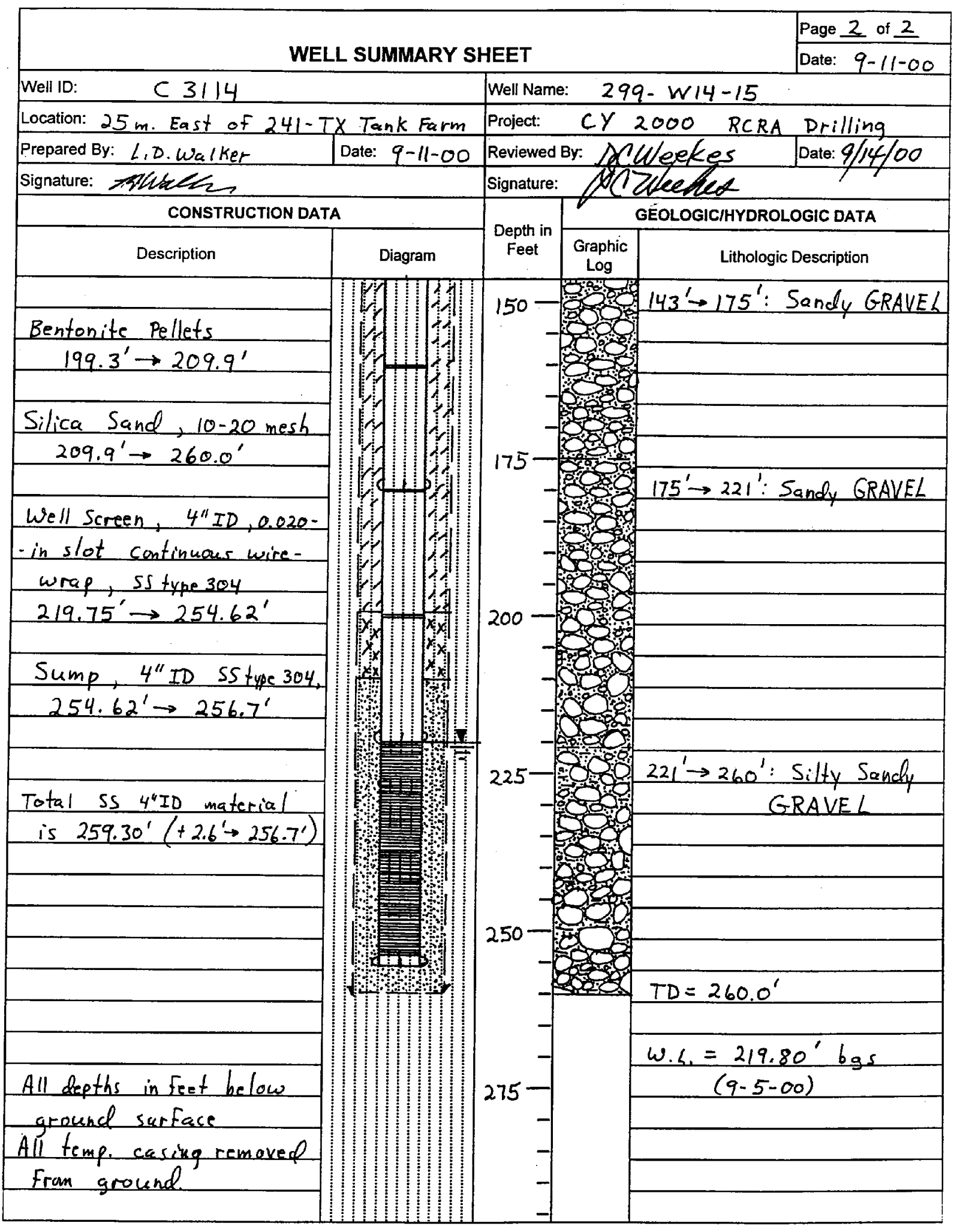

BHI-EE-189 (12/97) 


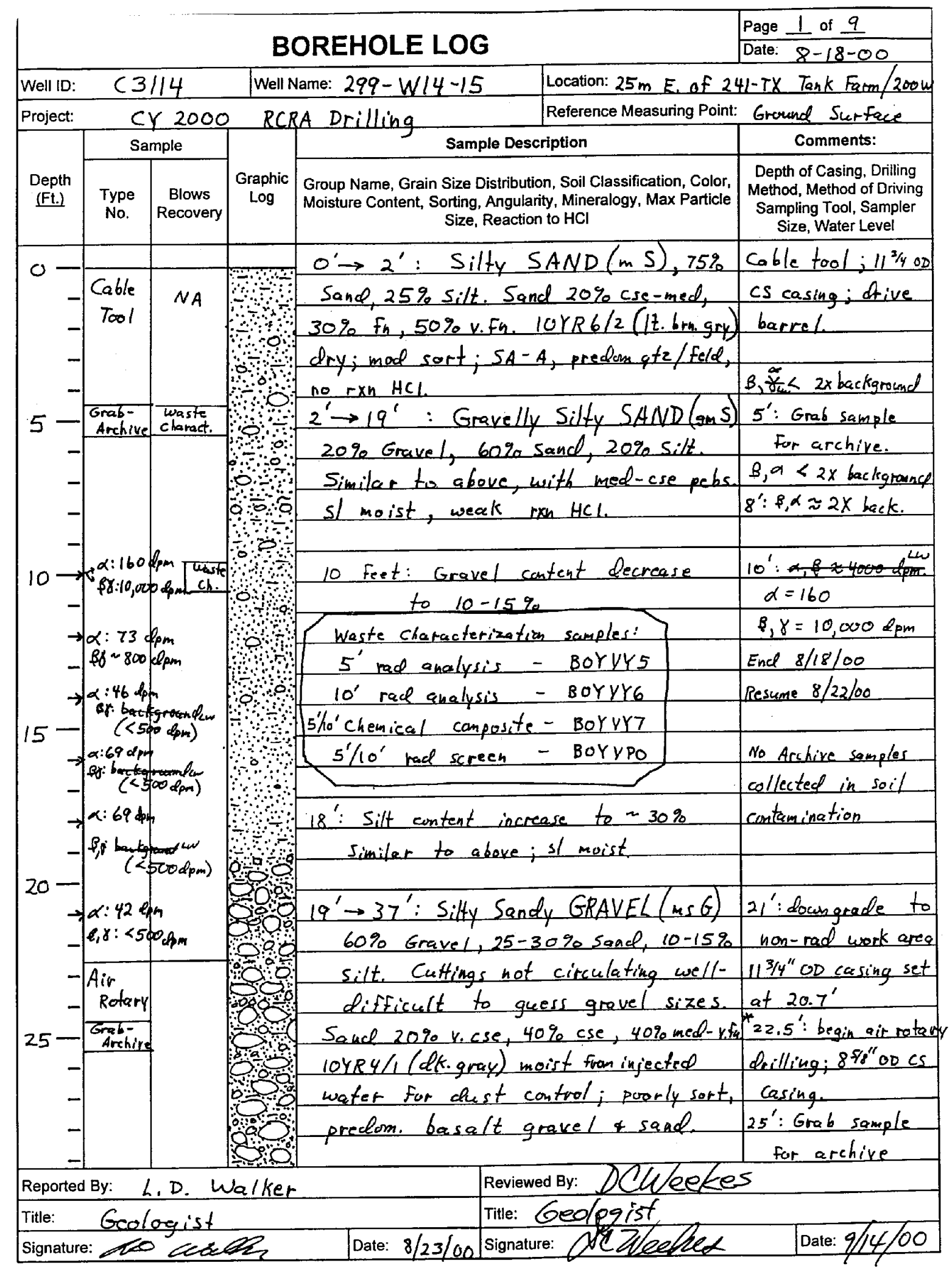

BHI-EE-183 (12/97) 


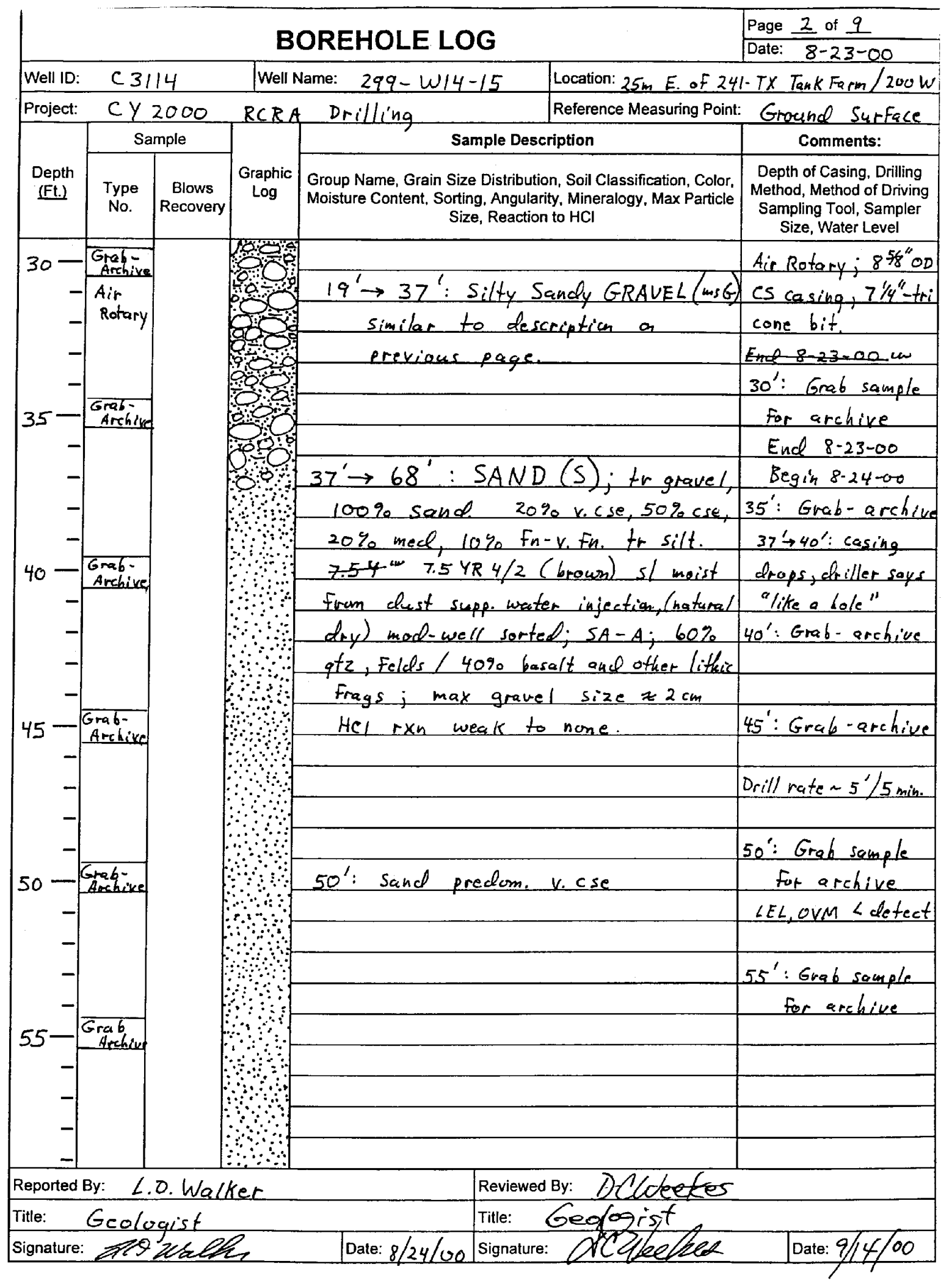

BHI-EE-183 (12/97) 


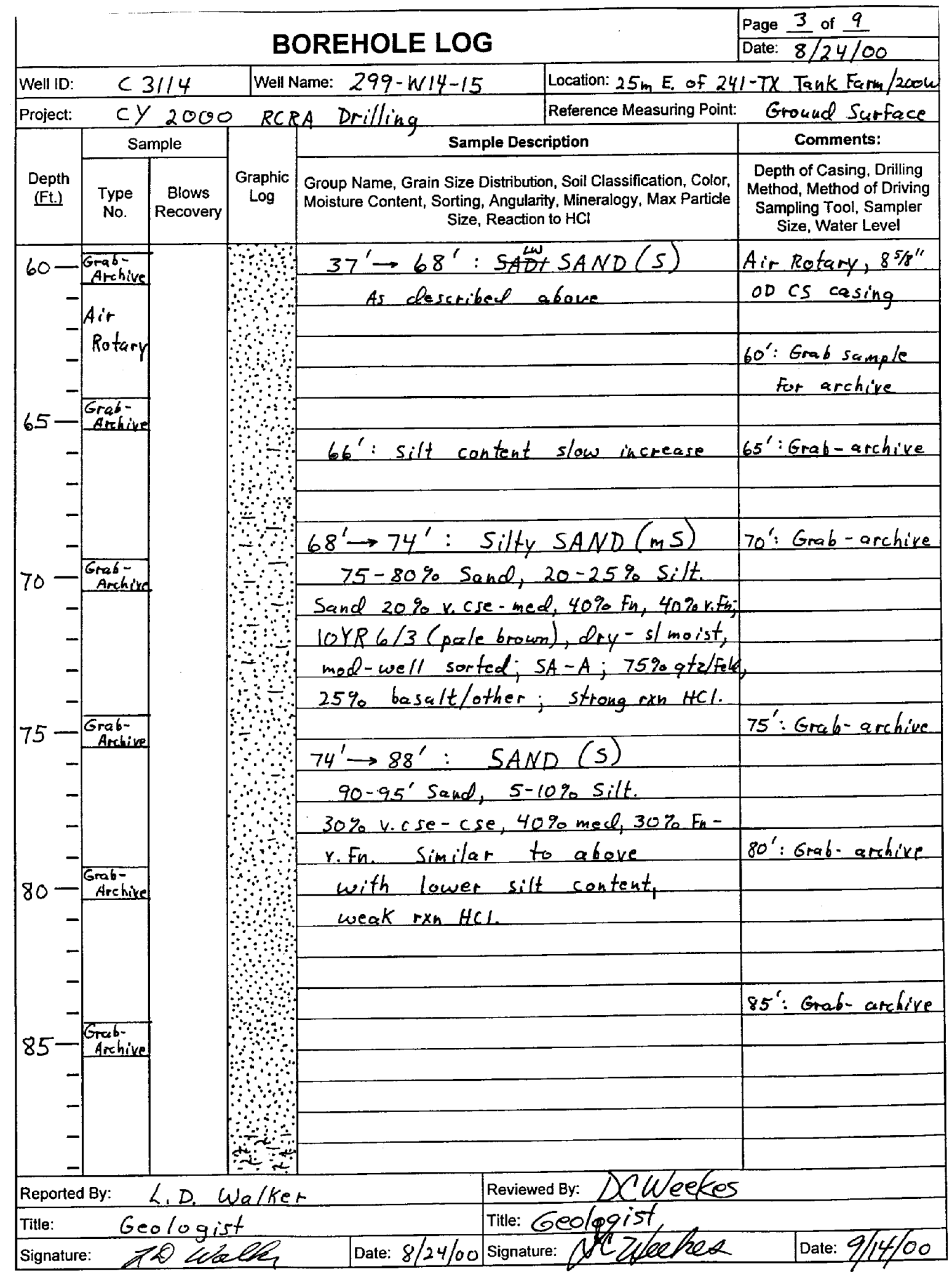

BHI-EE-183 (12/97) 


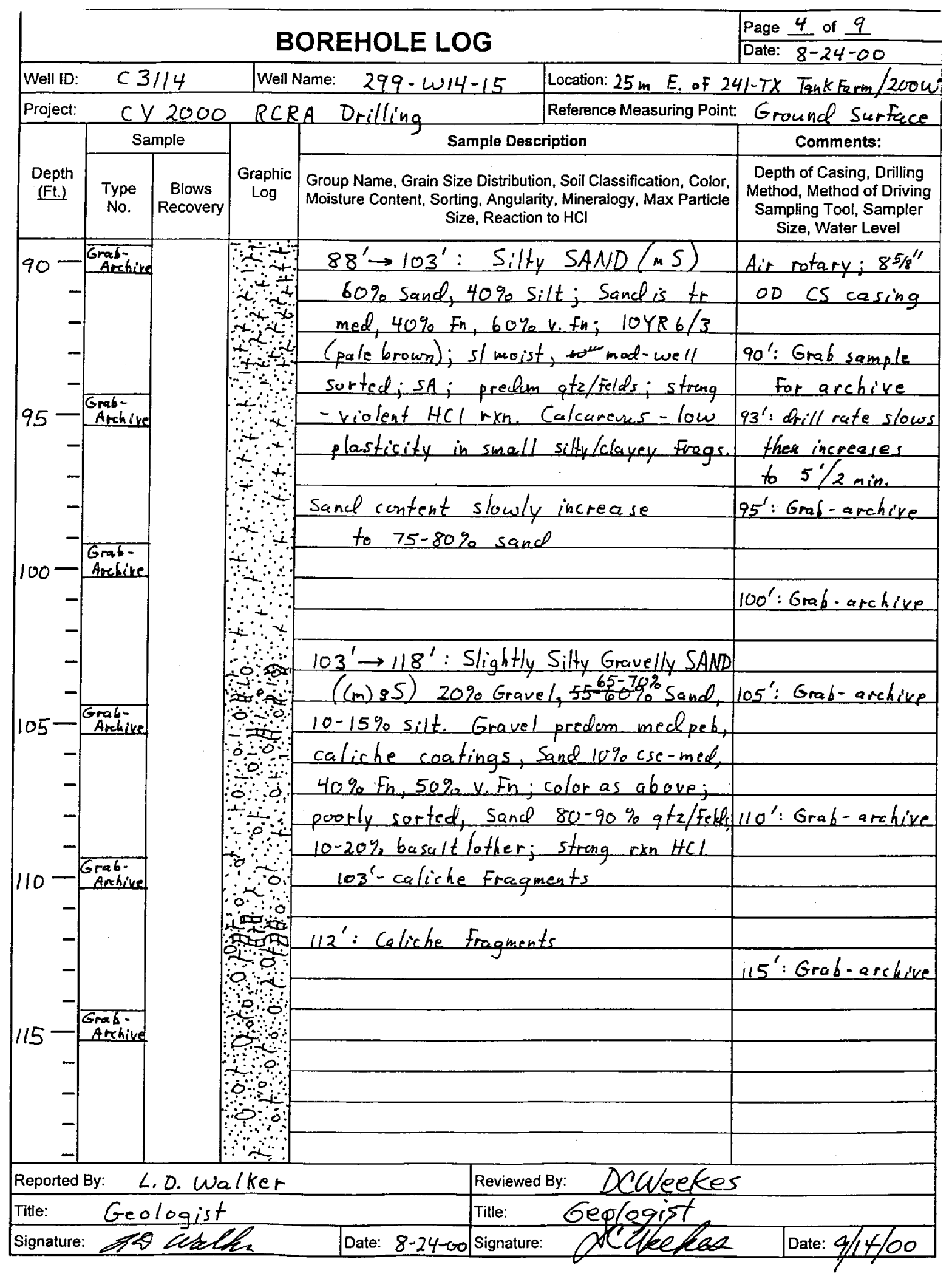

BHI-EE-183 (12/97) 


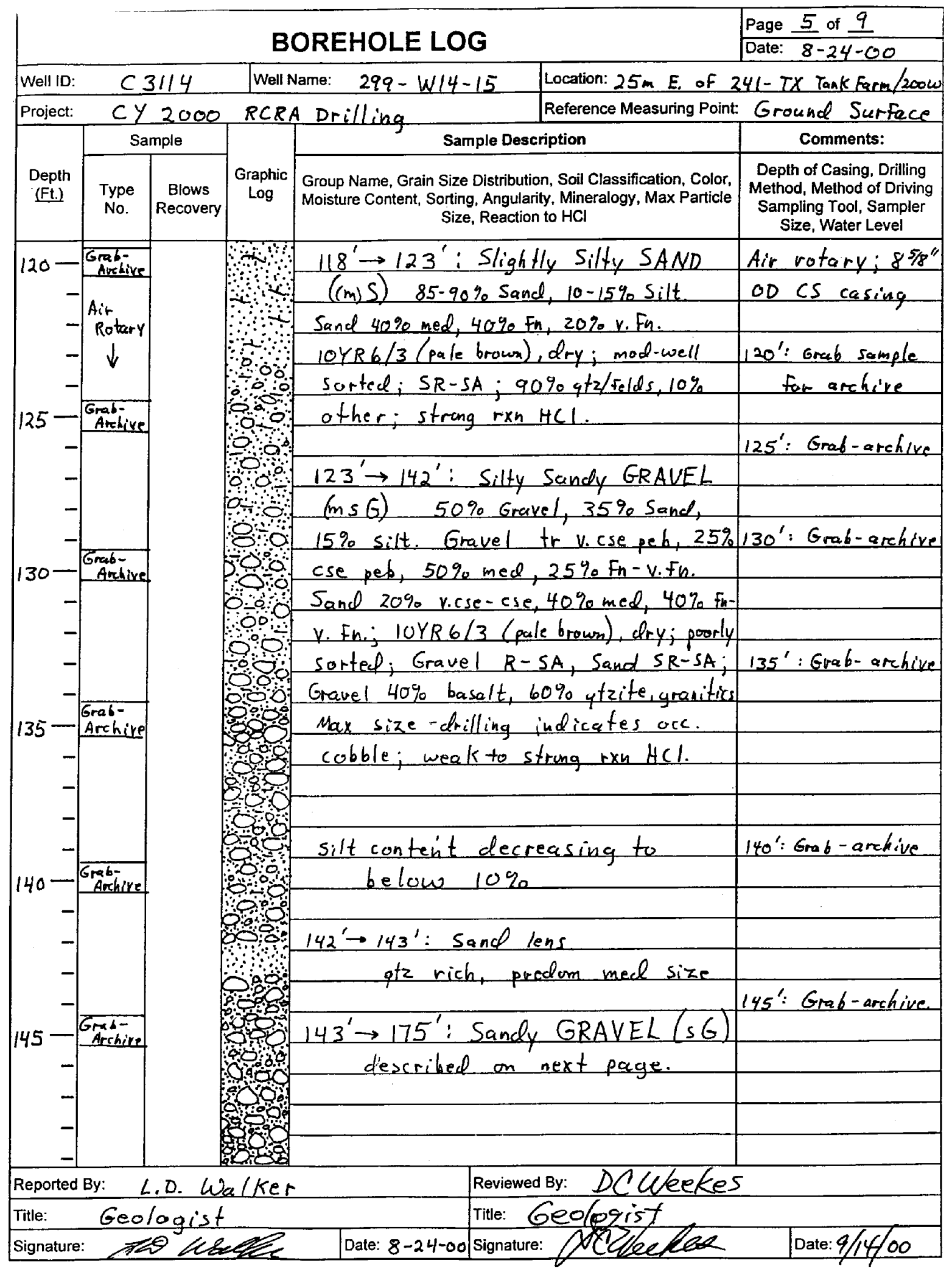

BHI-EE-183 (12/97) 


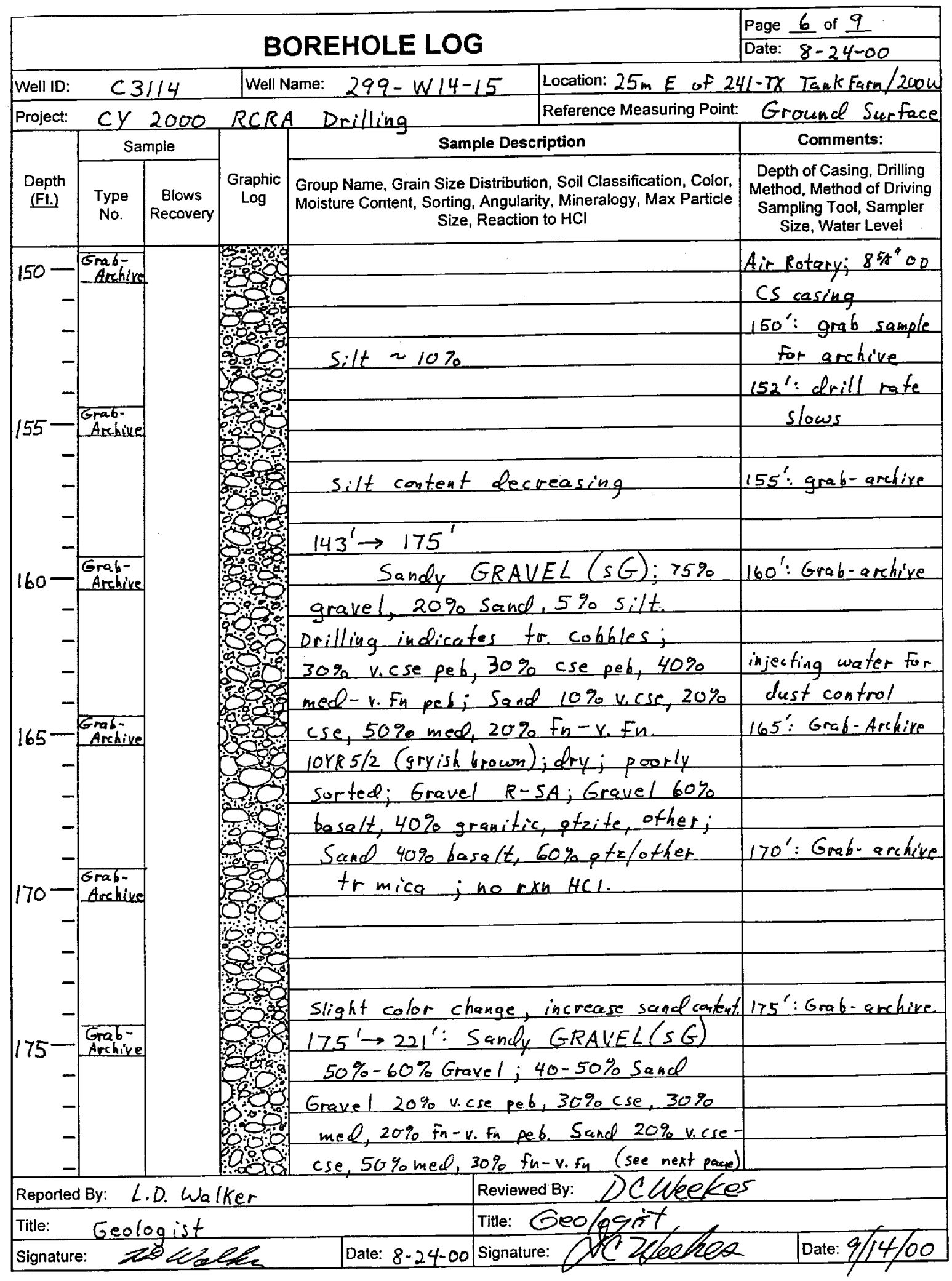

BHI-EE-183 (12/97) 


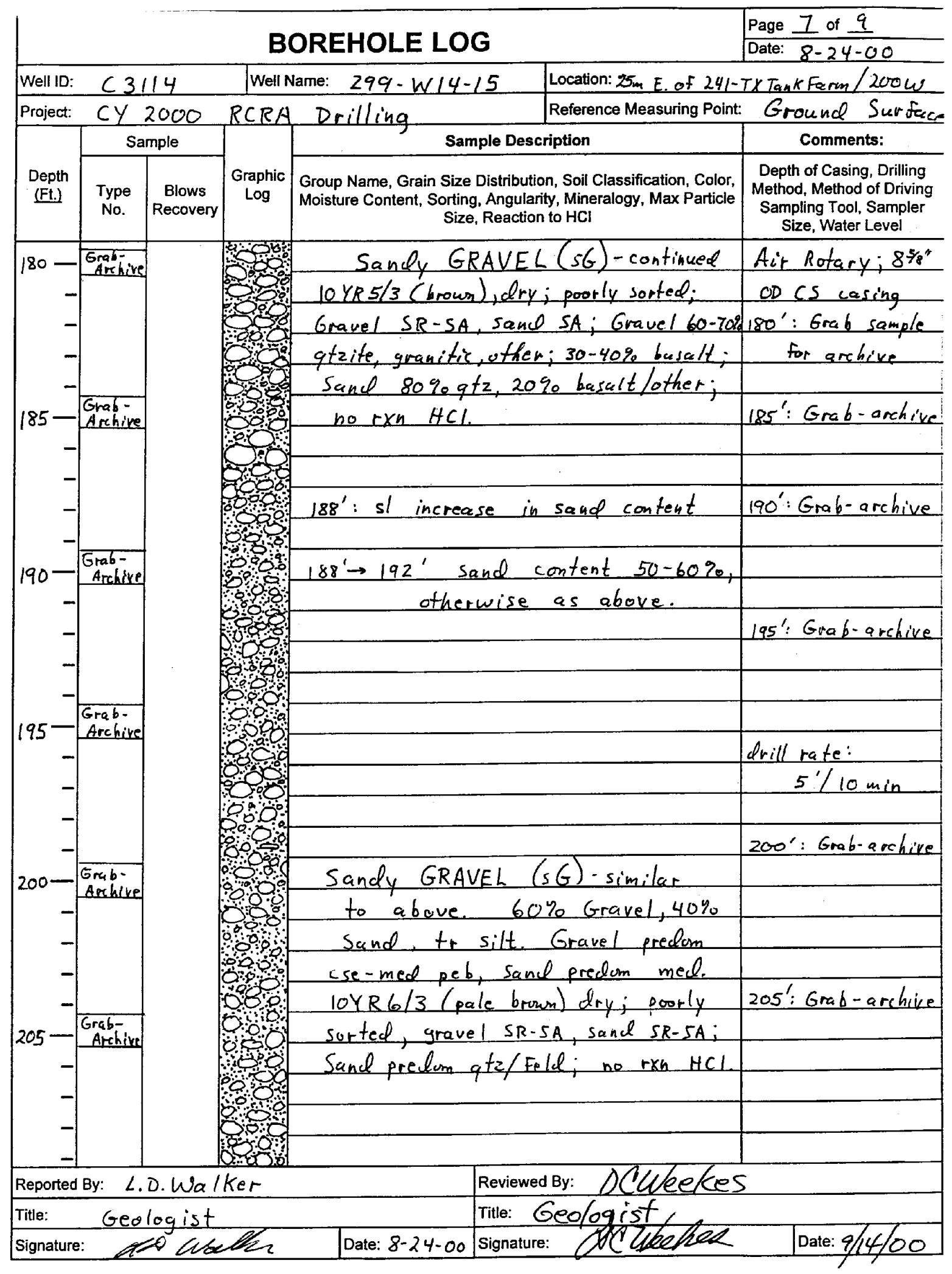

BHI-EE-183 (12/97) 


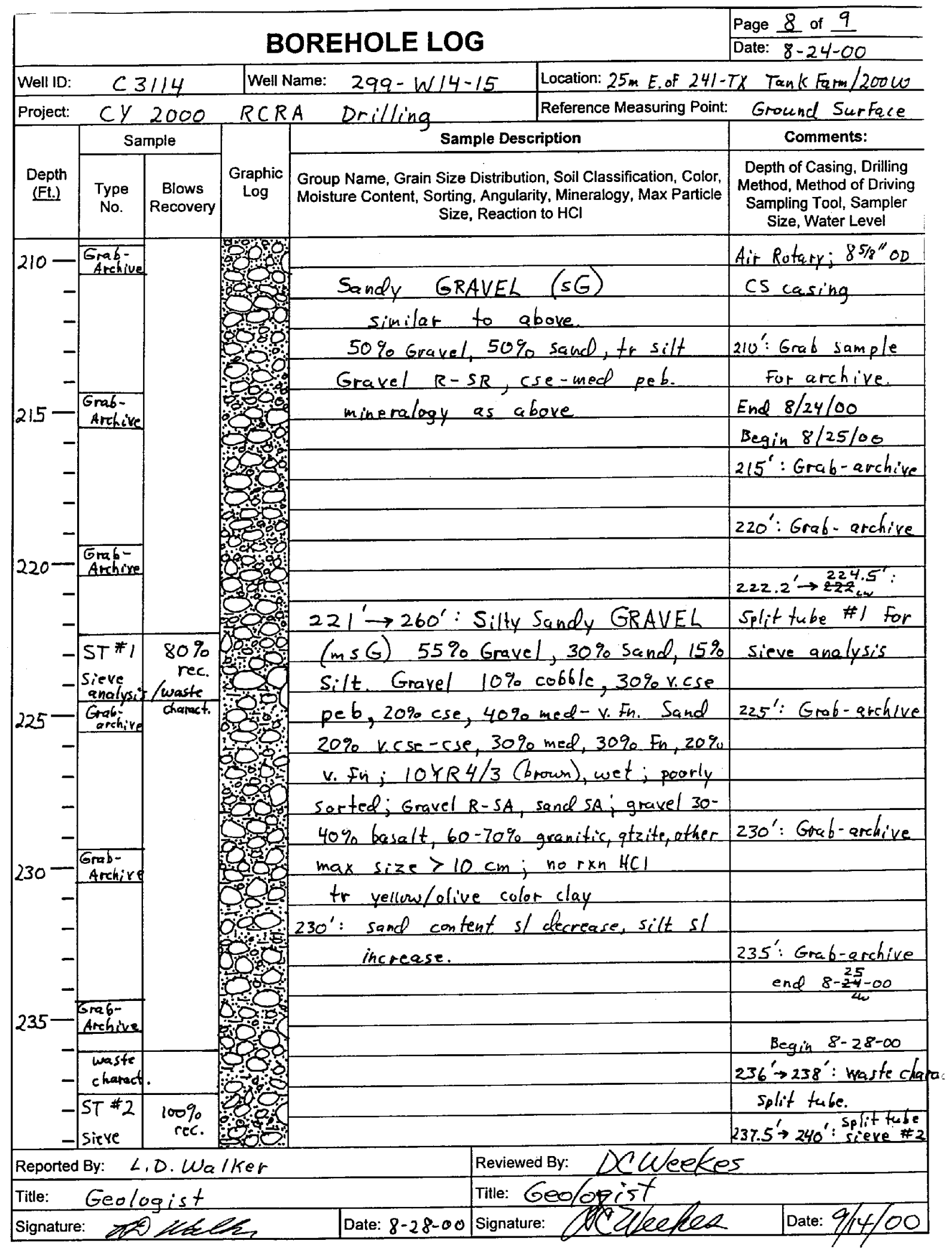

BHI-EE-183 (12/97) 


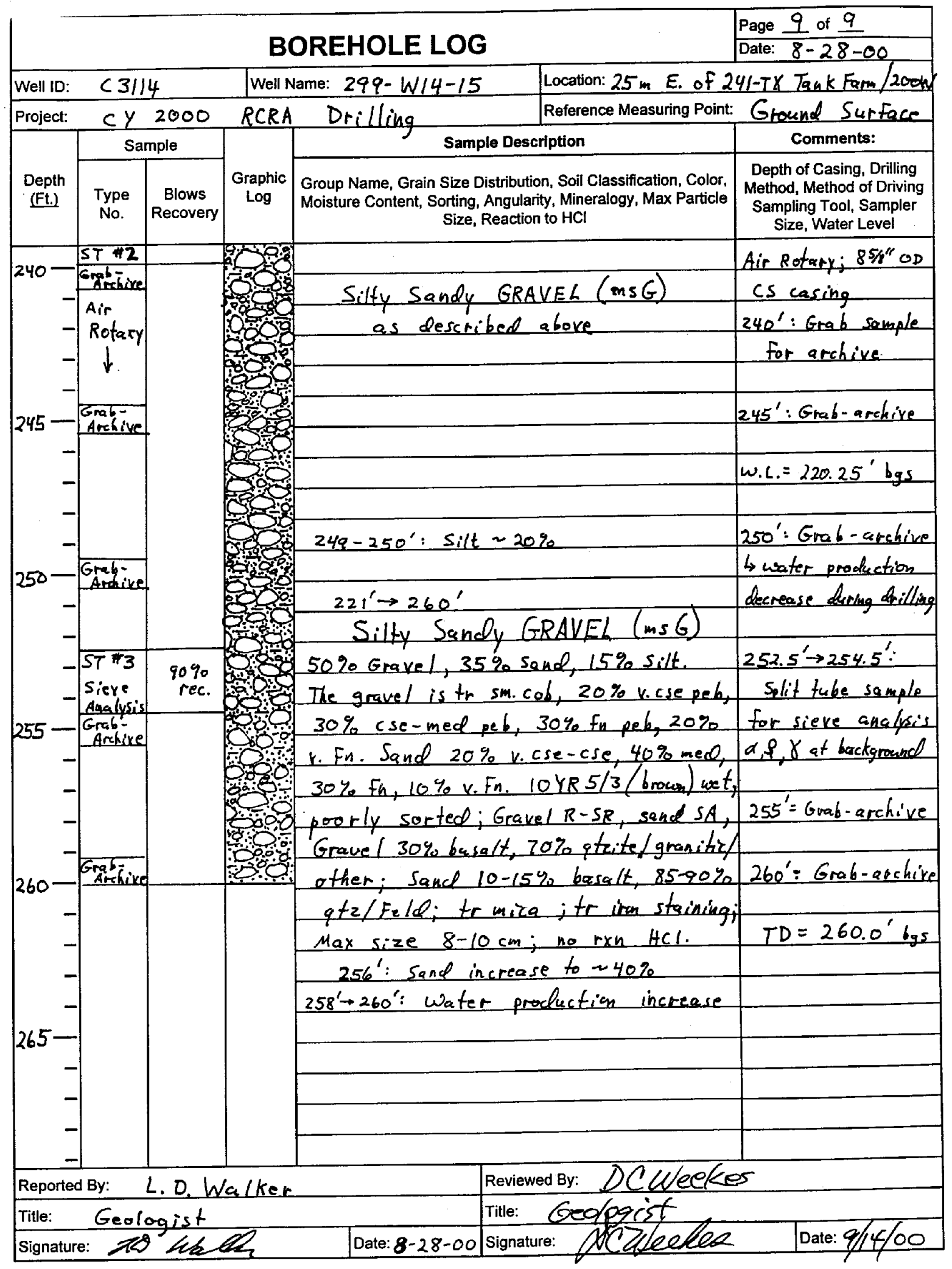

BHI-EE-183 (12/97) 


\section{WELL CONSTRUCTION SUMMARY REPORT}

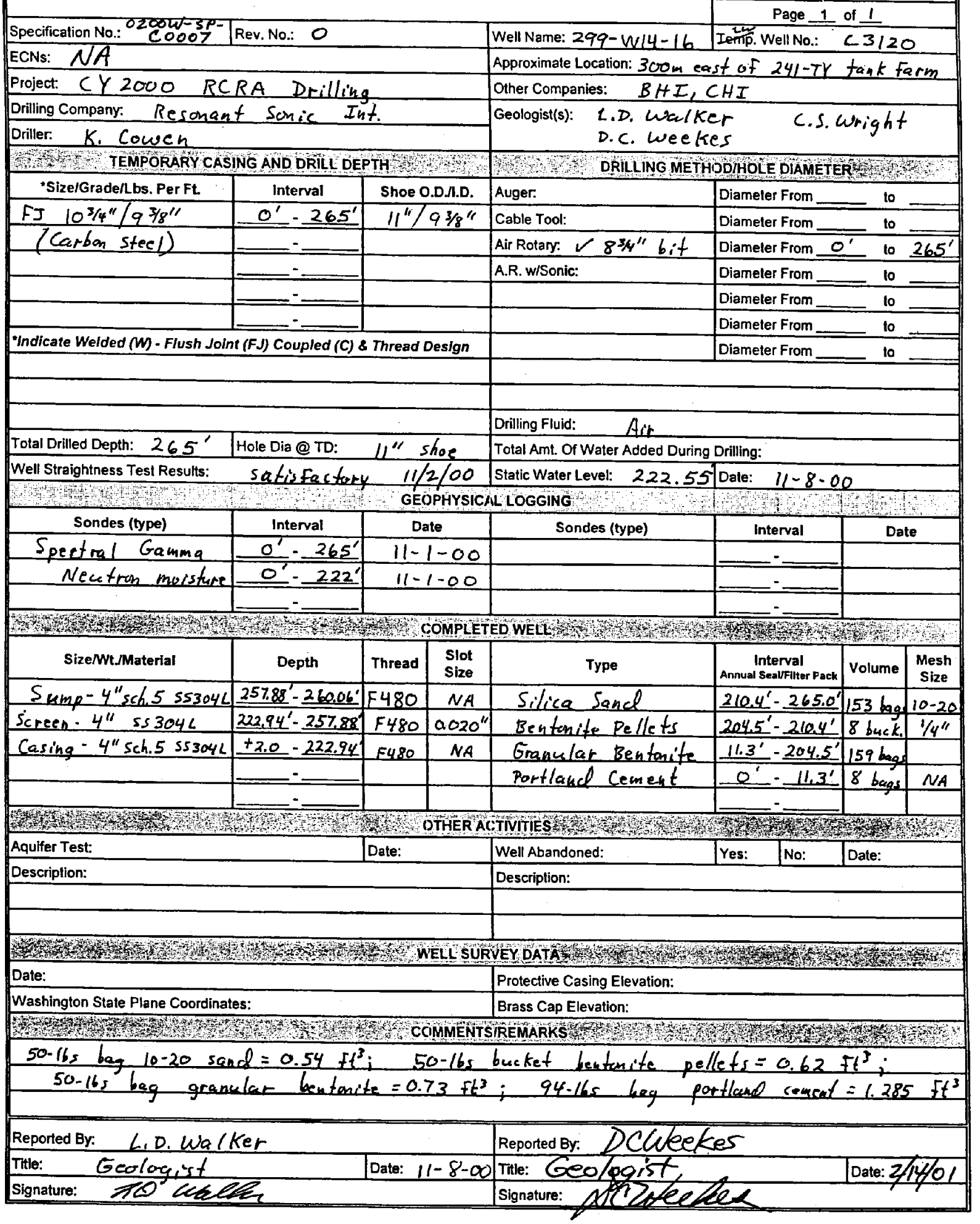

BHI-EE-181 (12/97) 


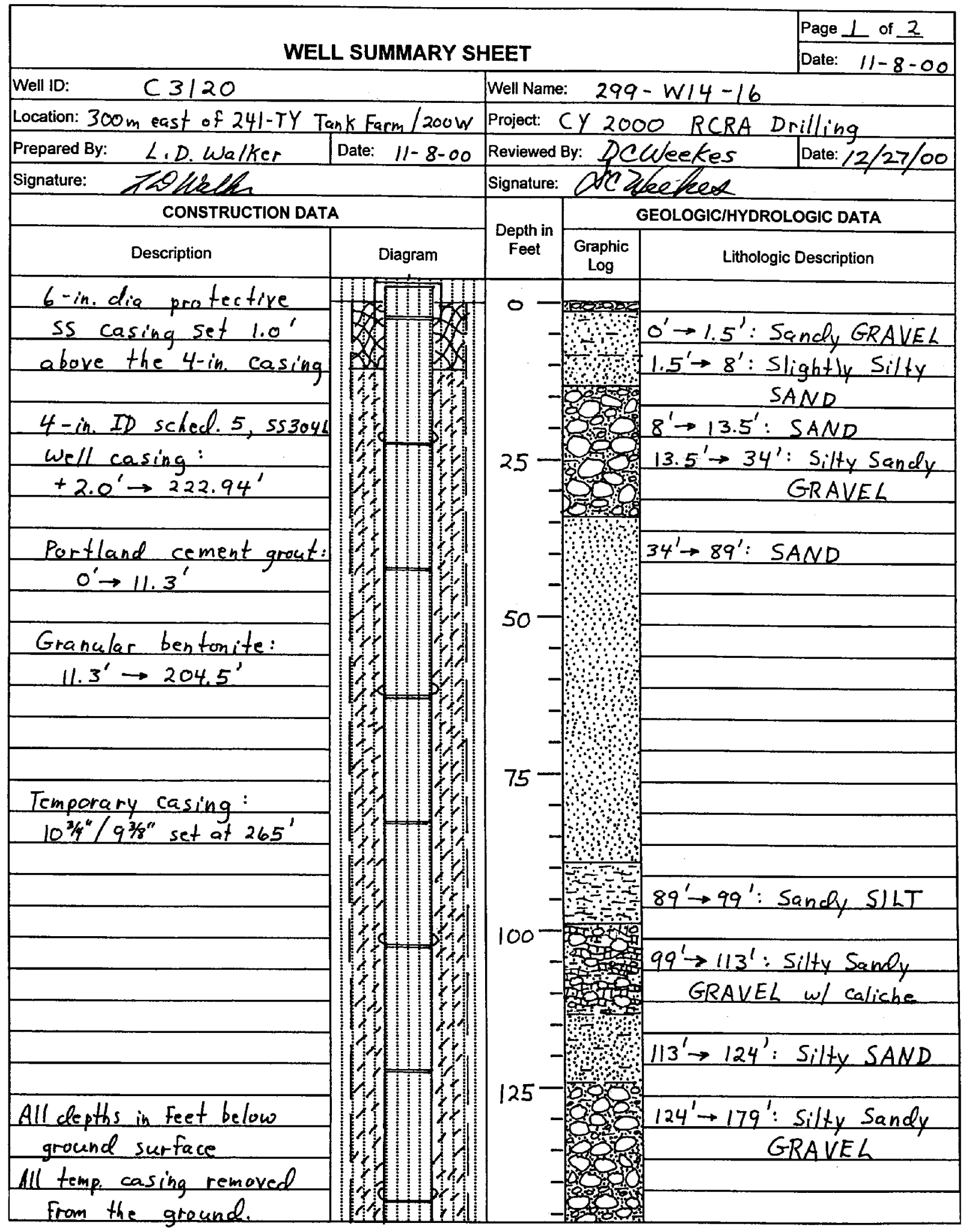

BHI-EE-189 (12/97) 


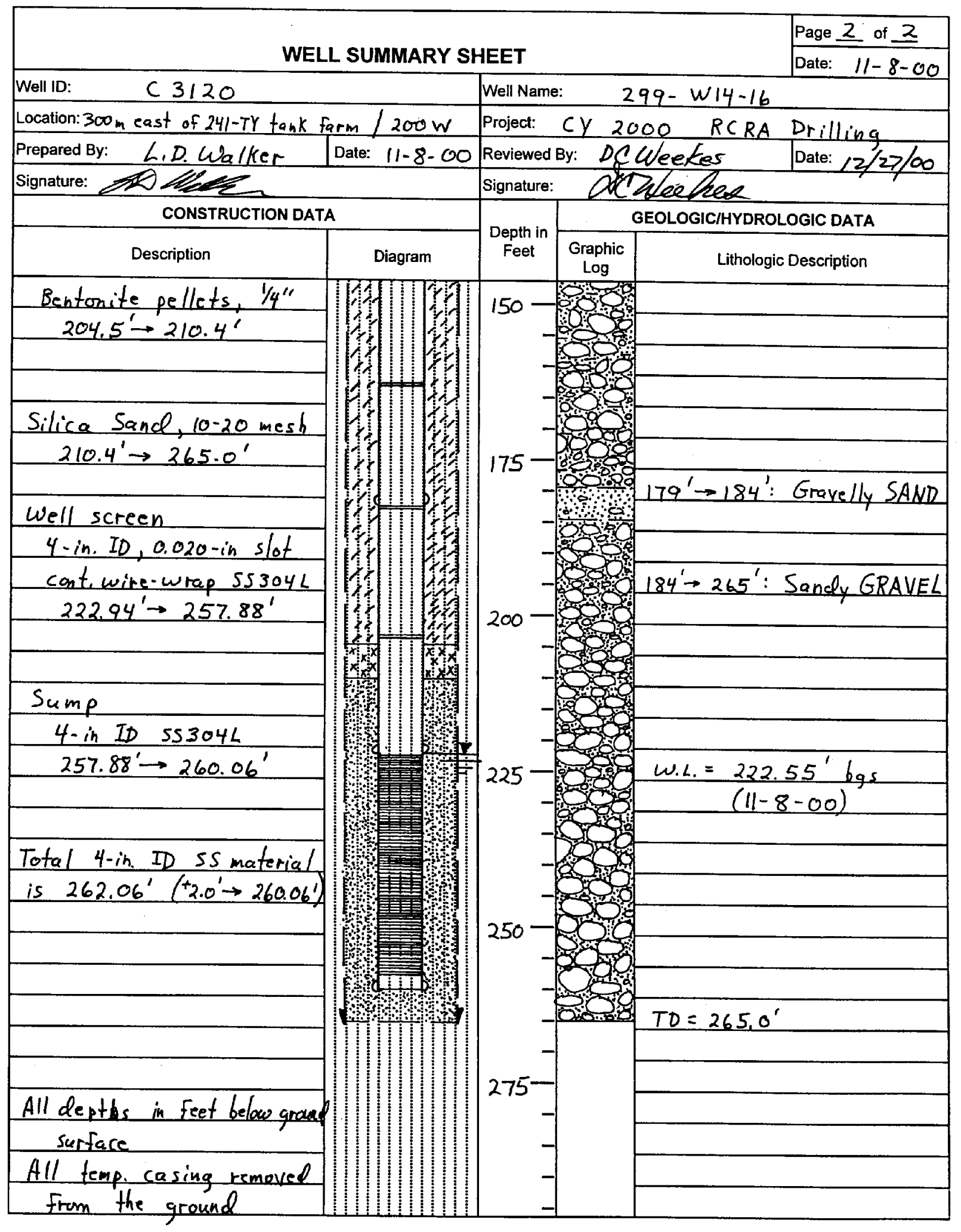

BHI-EE-189 (12/97) 


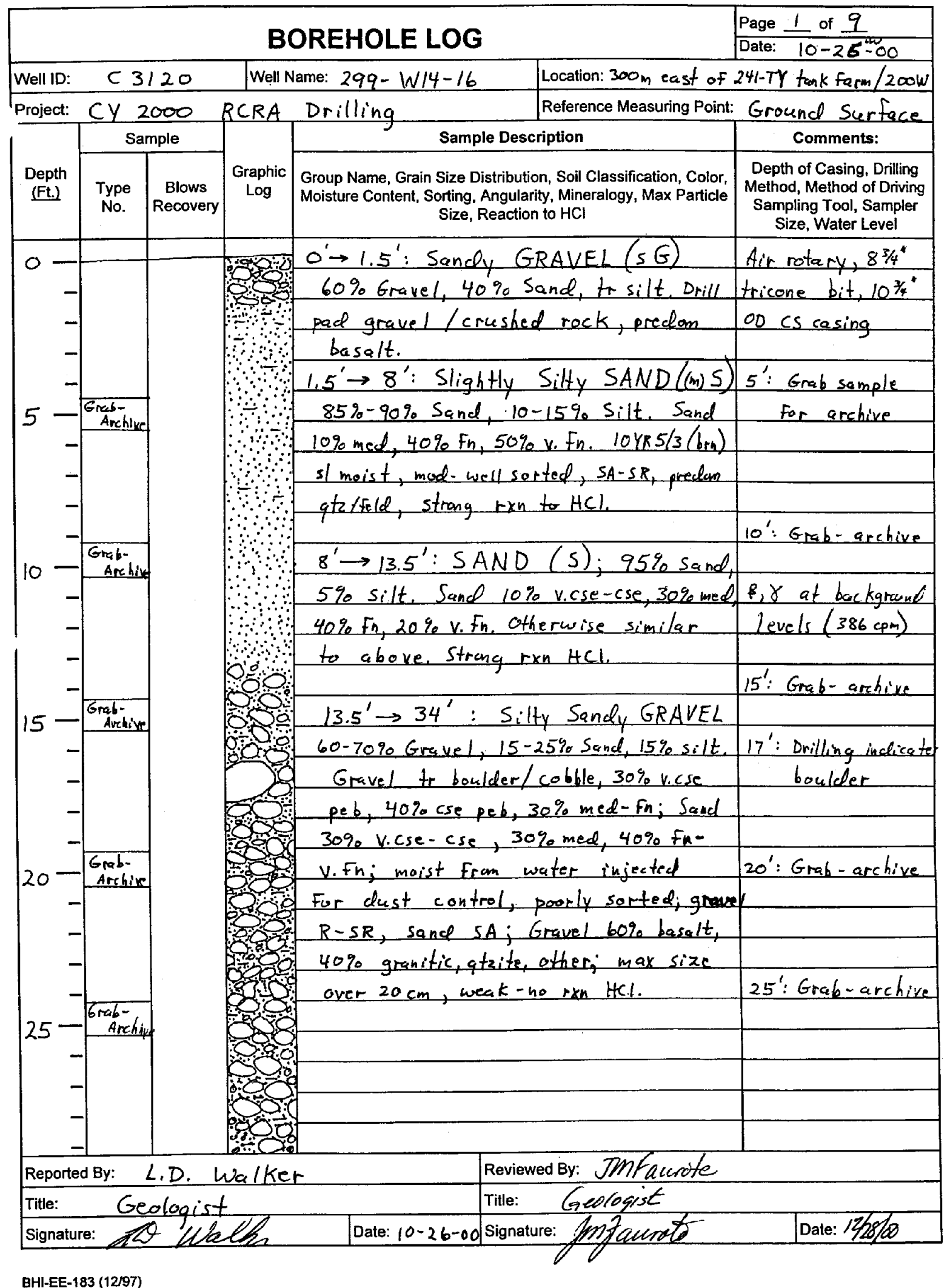




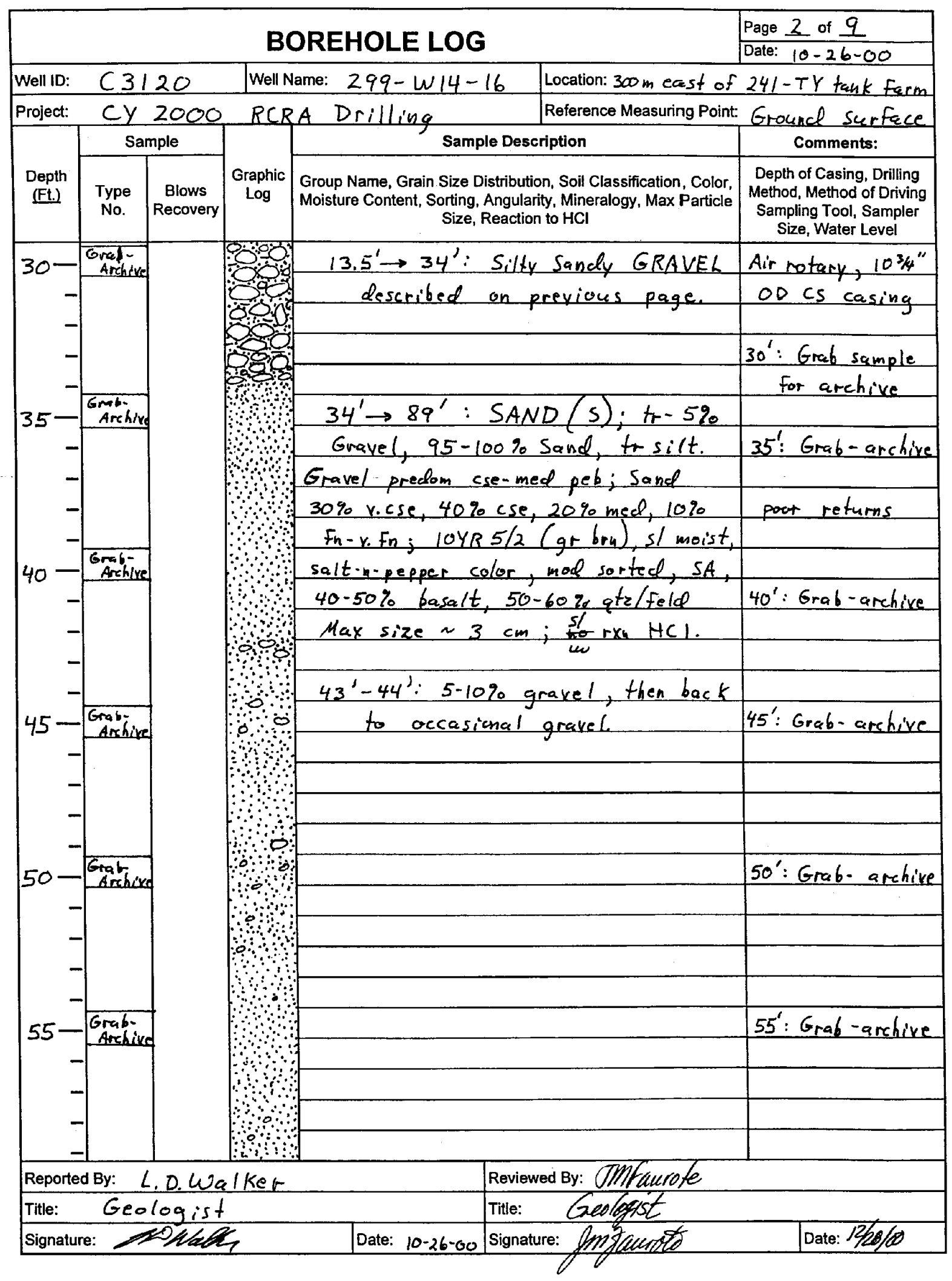

BH-EE-183 (12/97) 


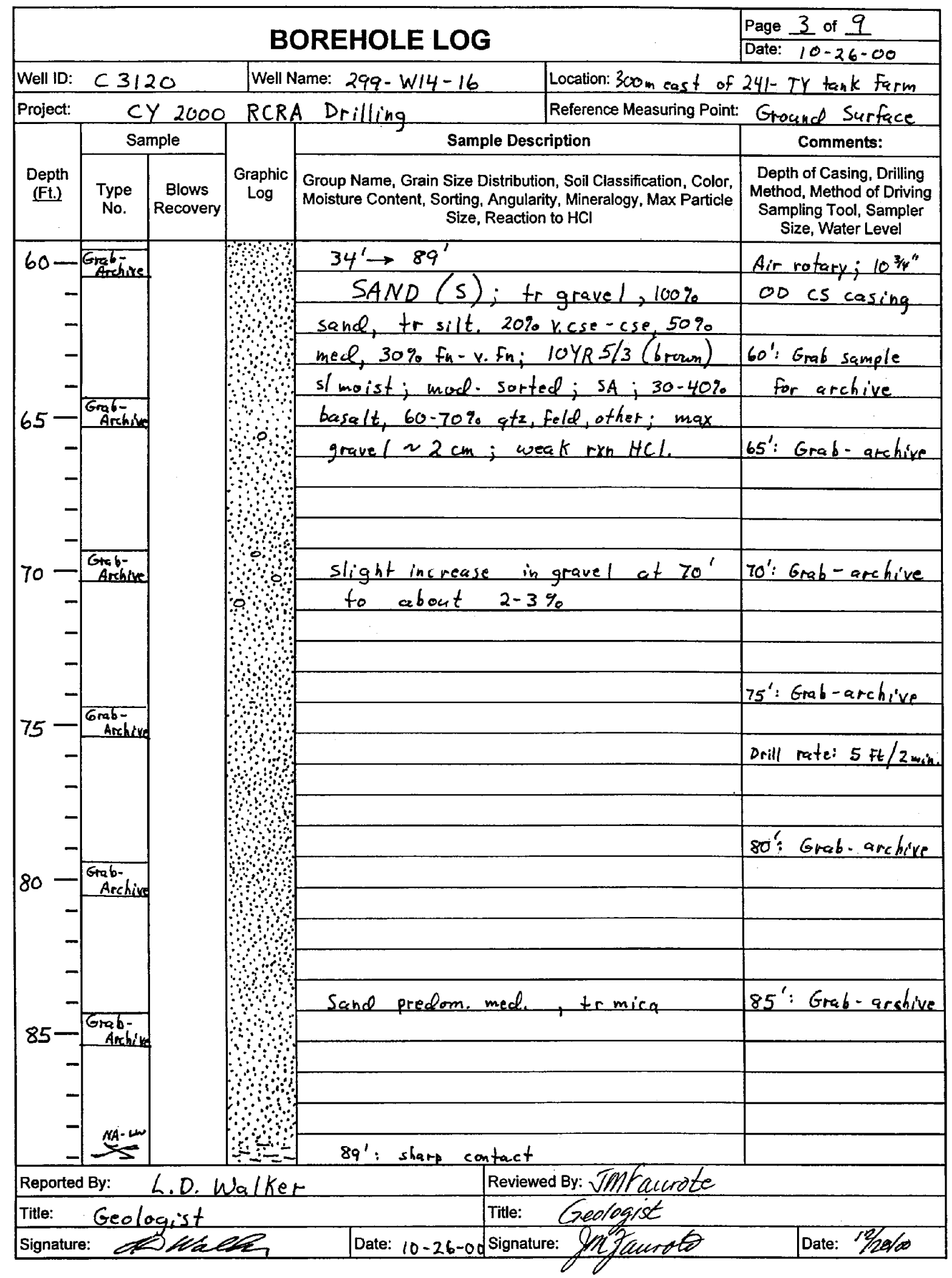

BHI-EE-183 (12/97) 


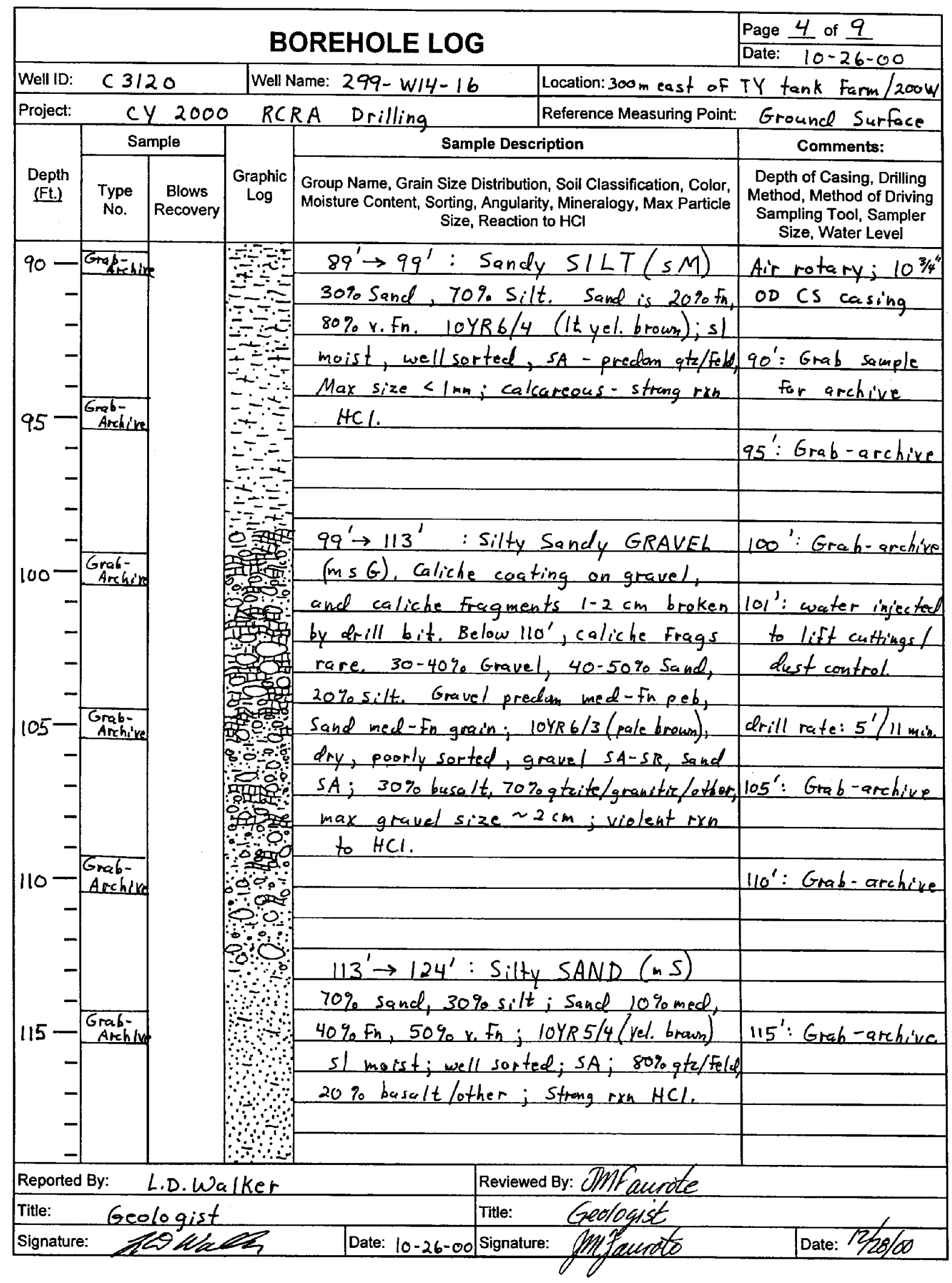

BHI-EE-183 (12/97) 


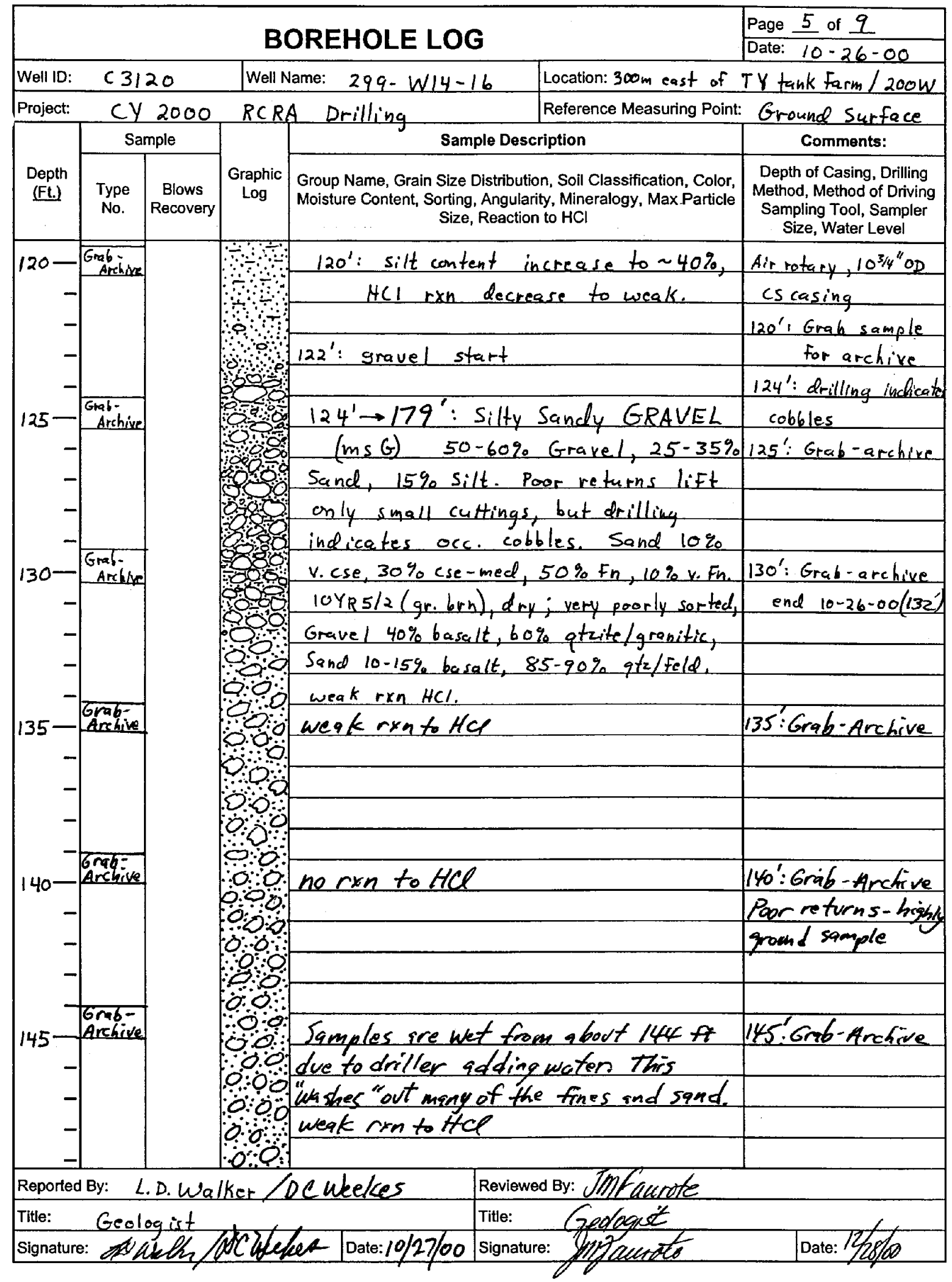

8HI-EE-183 (12/97) 


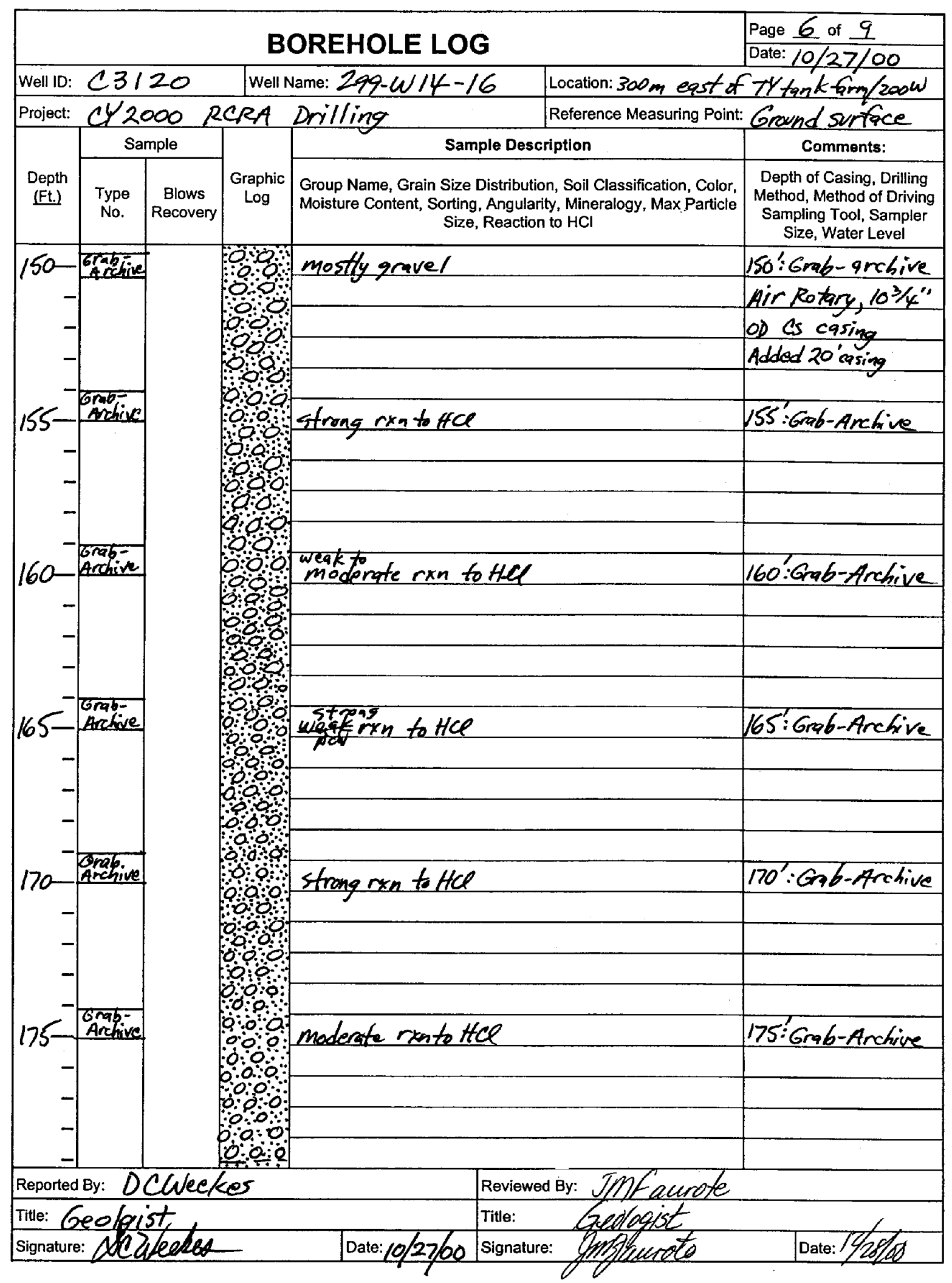

BHI-EE-183 (12/97) 


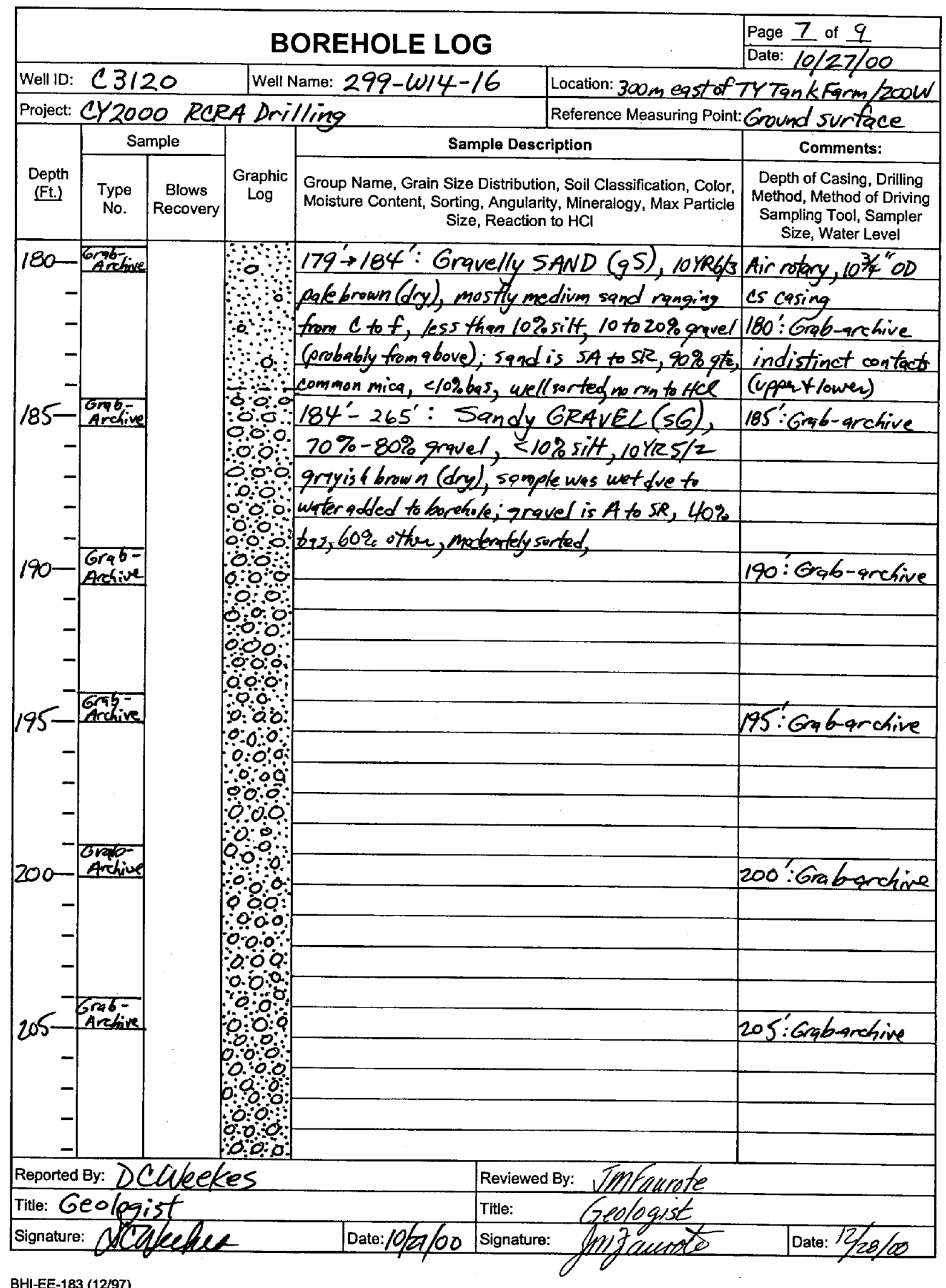




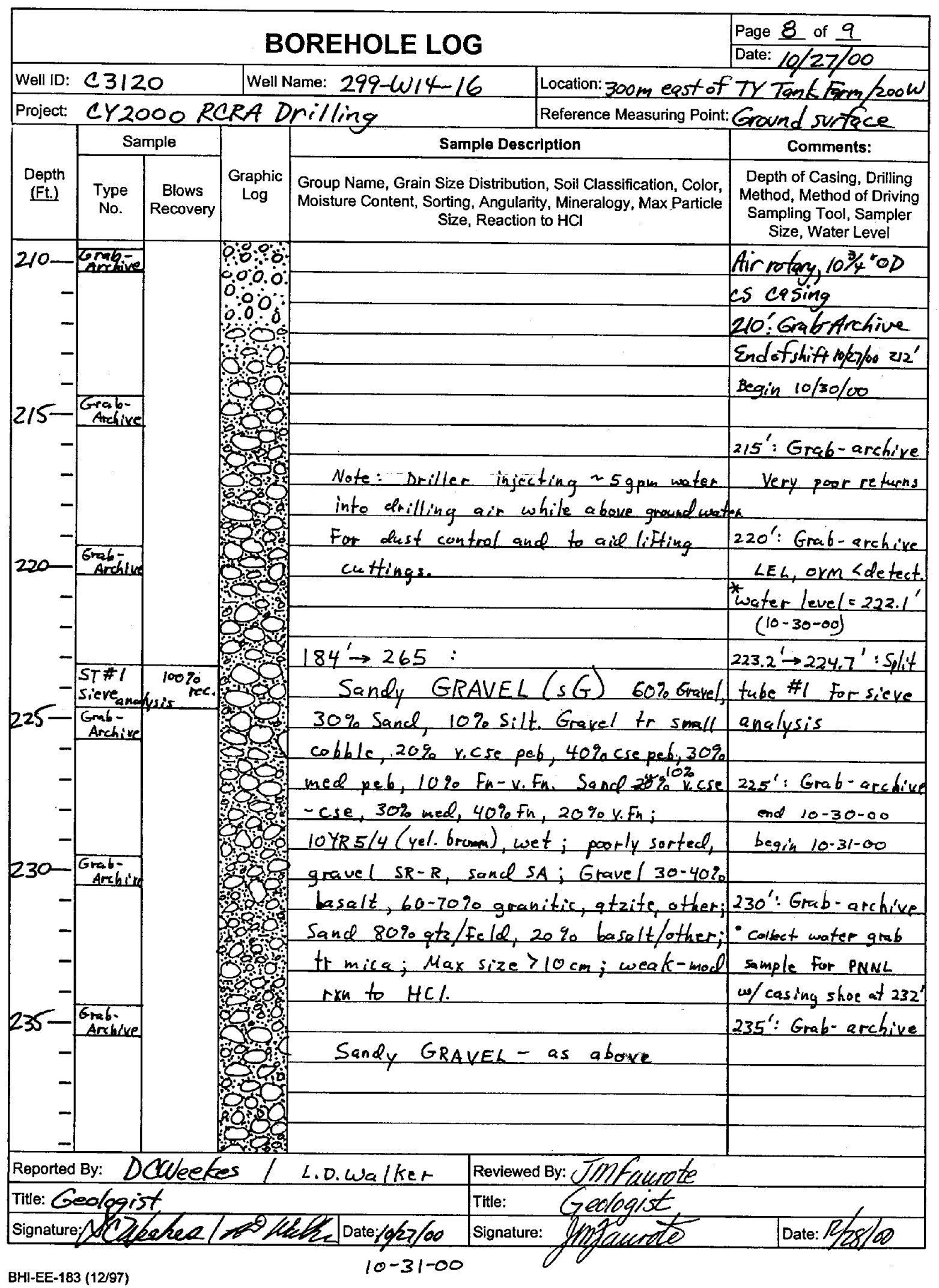




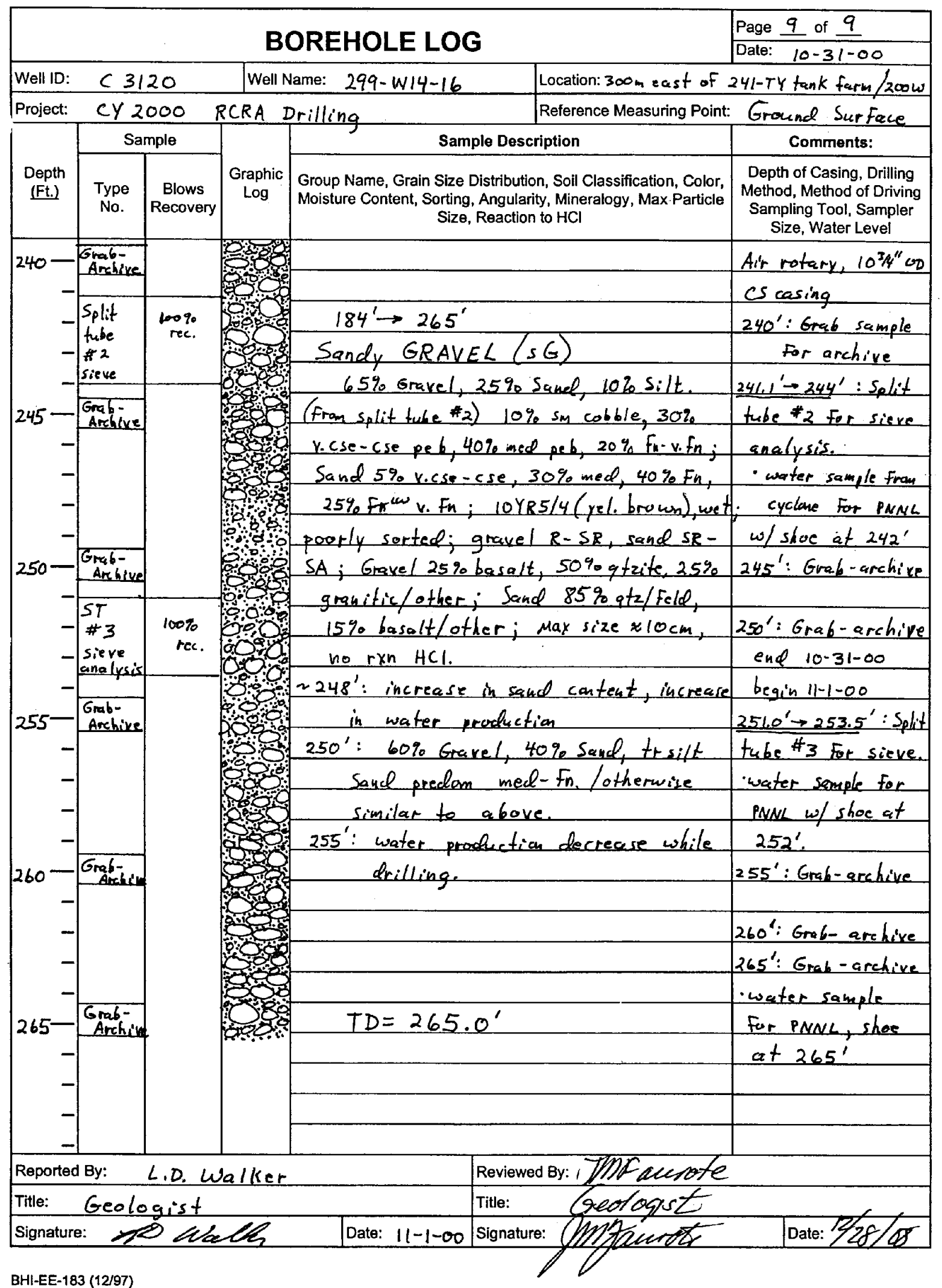

BHI-EE-183 (12/97) 


\section{WELL CONSTRUCTION SUMMARY REPORT}

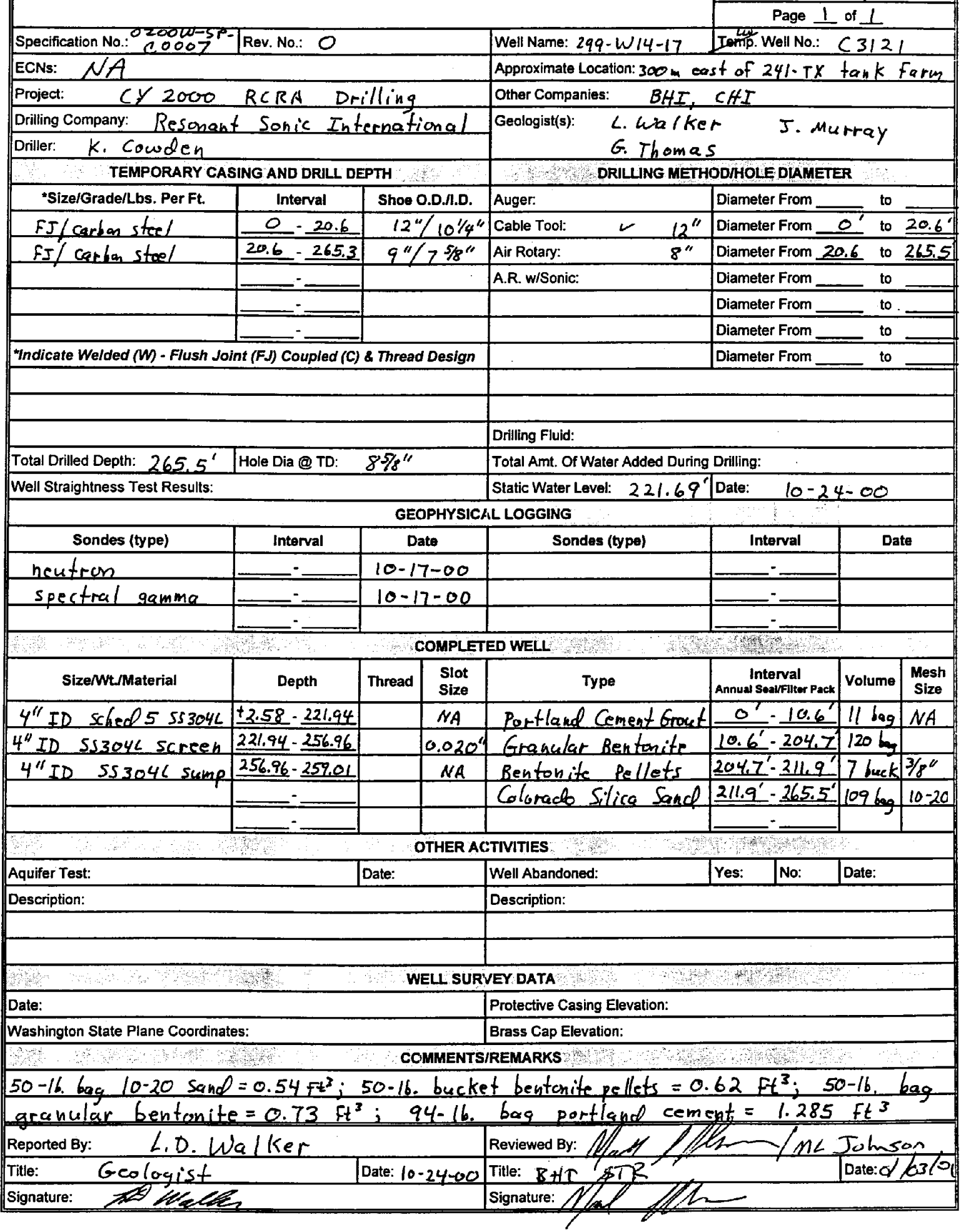

BHI-EE-181 (12/97) 


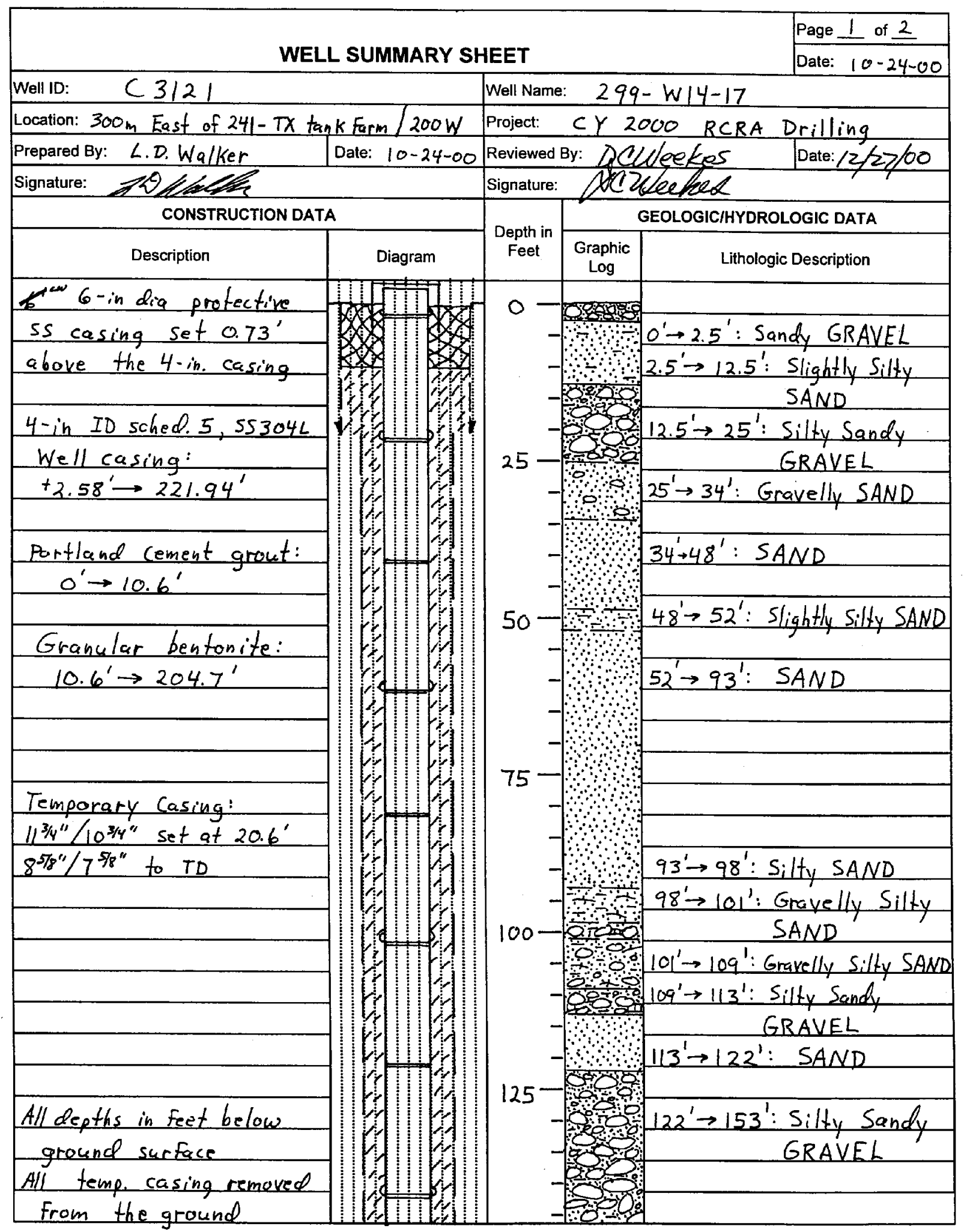

BHI-EE-189 (12/97) 


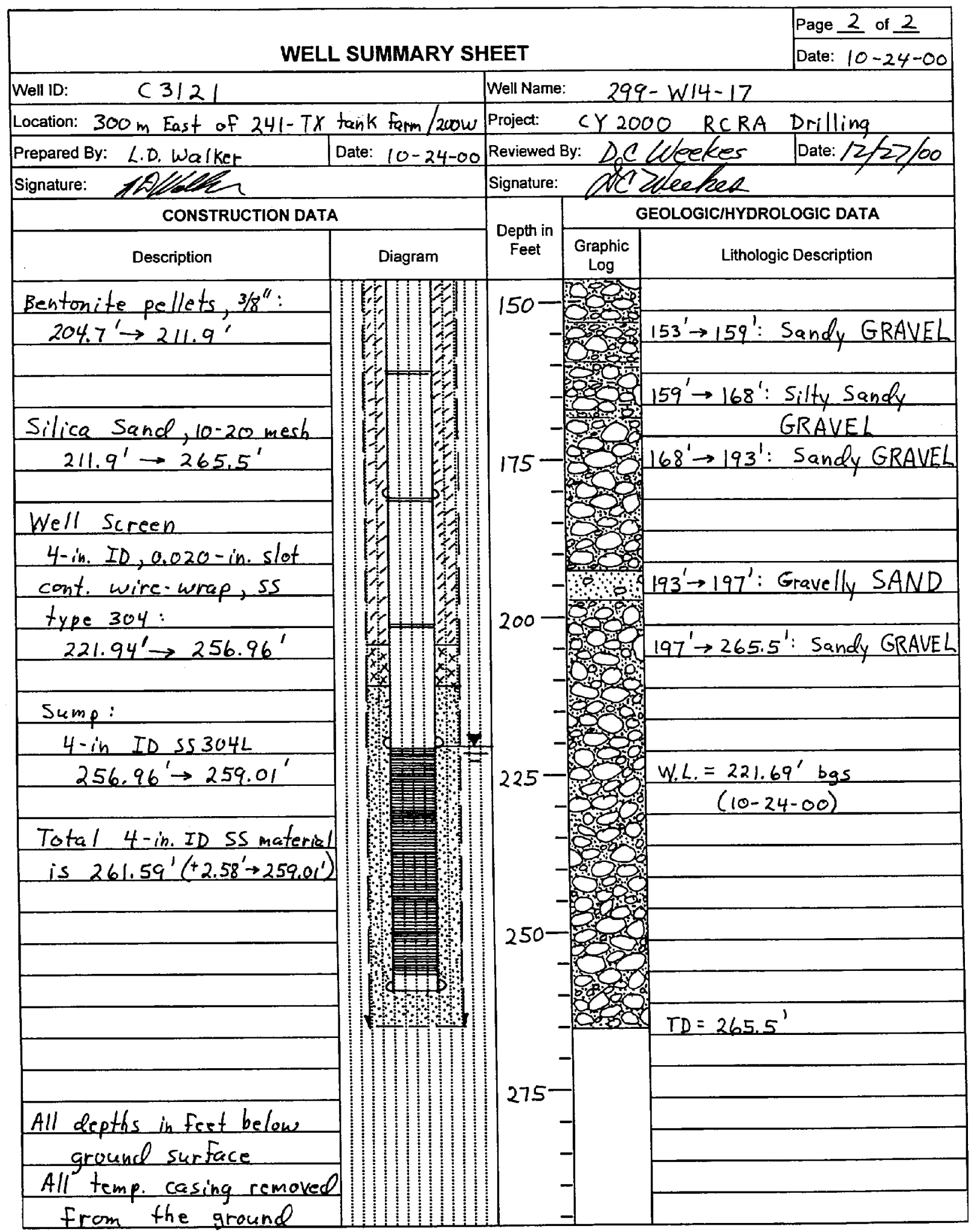

BHI-EE-189 (12/97) 


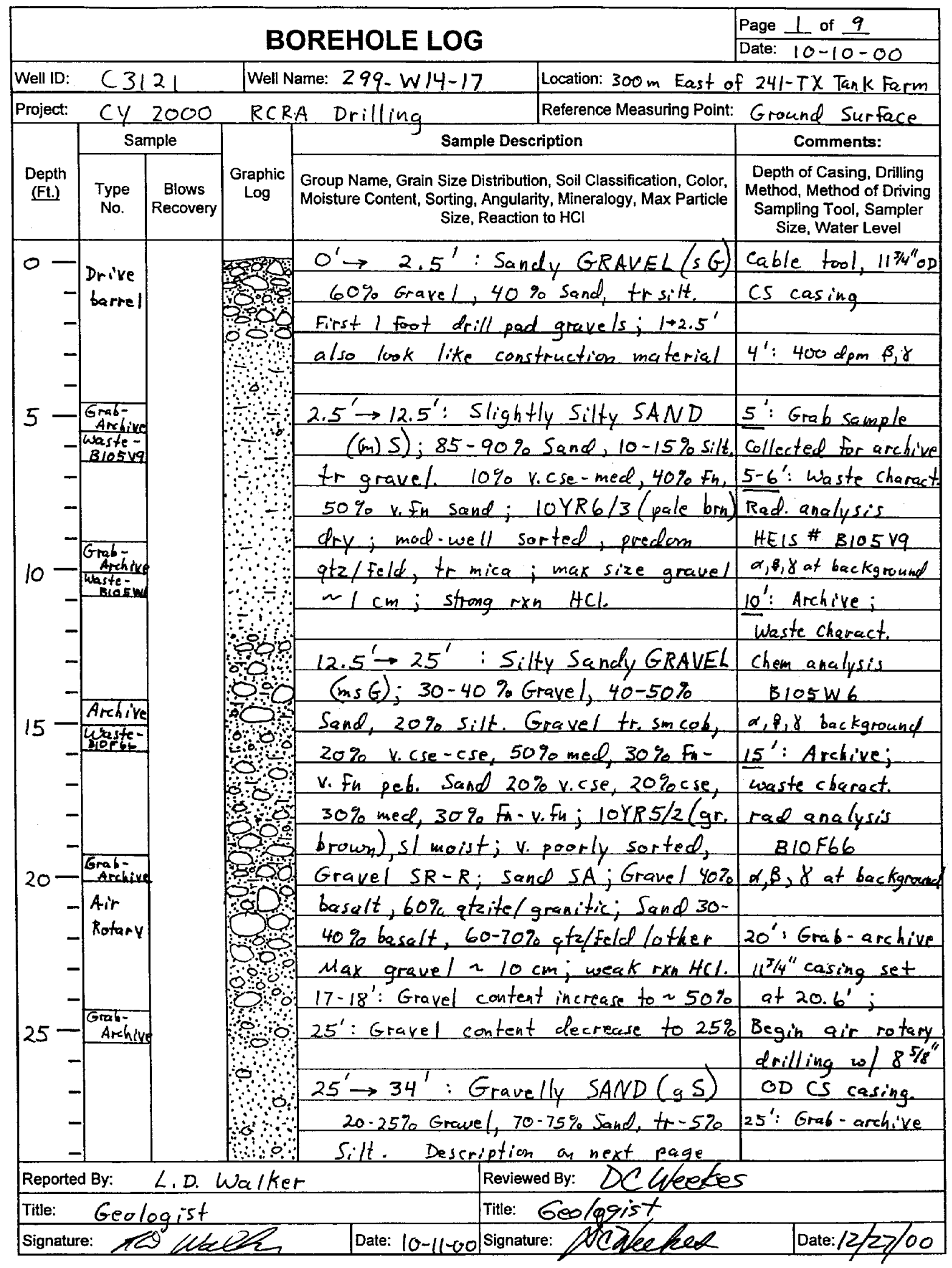

BHI-EE-183 (12/97) 


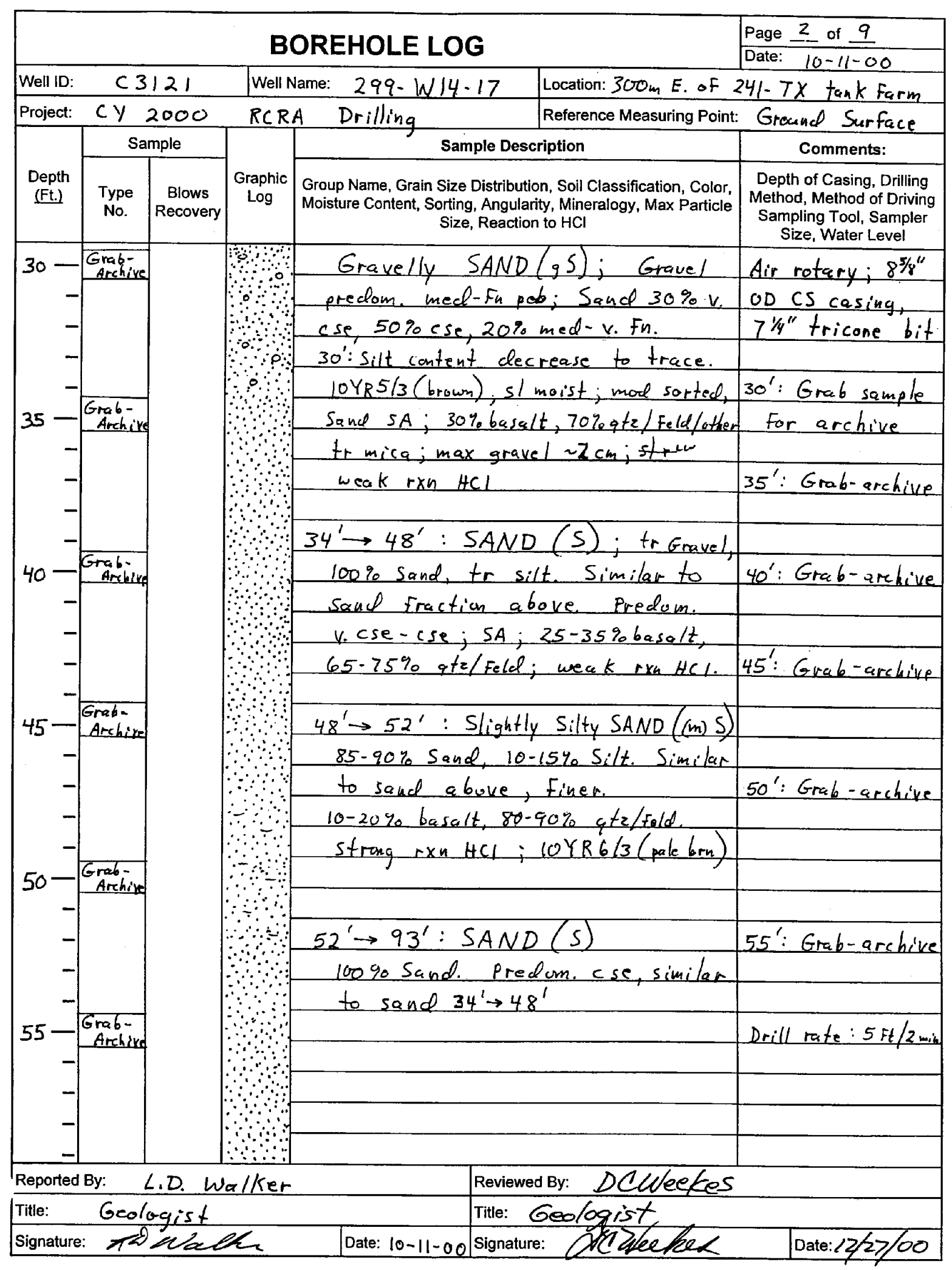

BHI-EE-183 (12/97) 


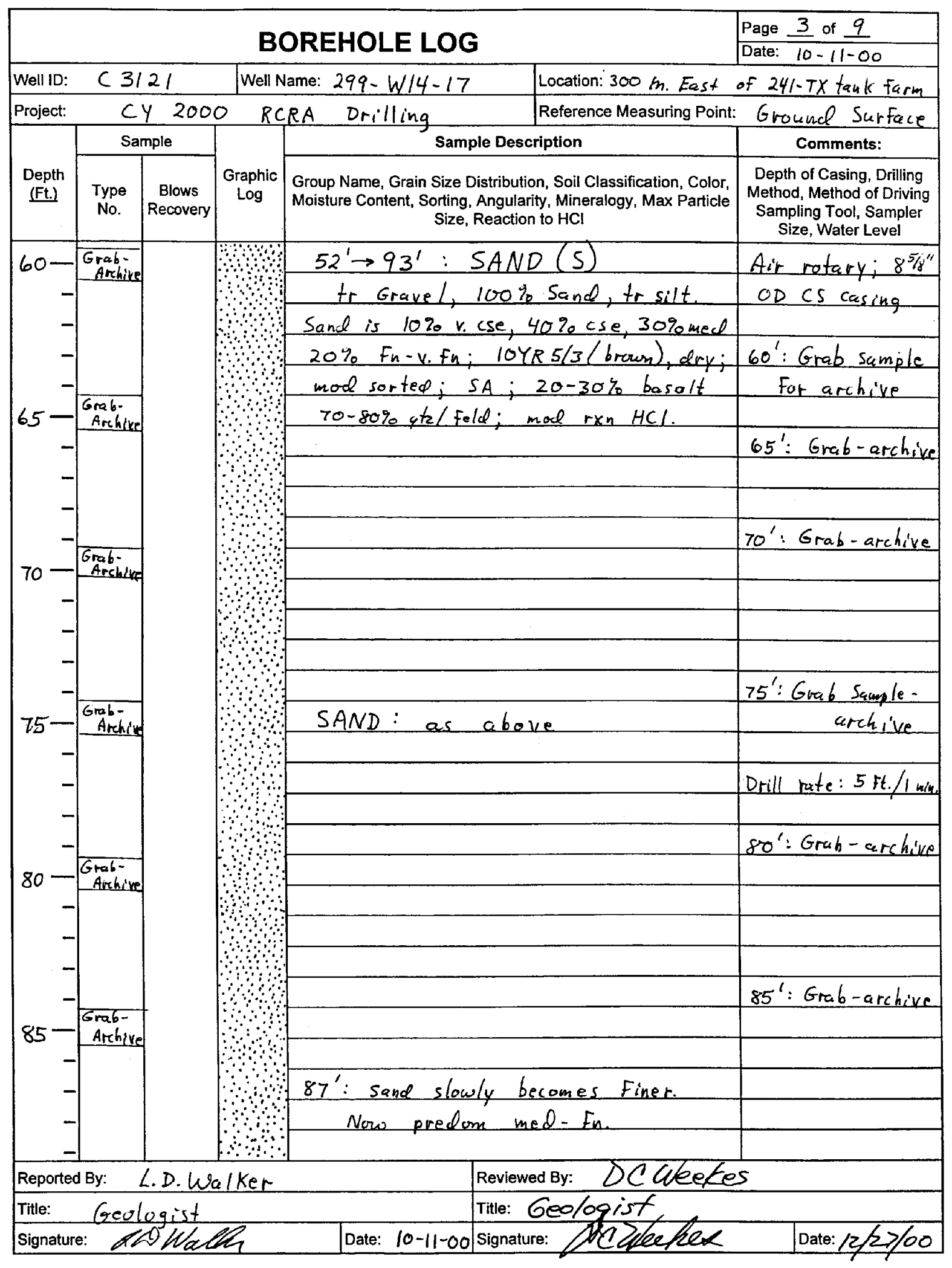

BHI-EE-183 (12/97) 


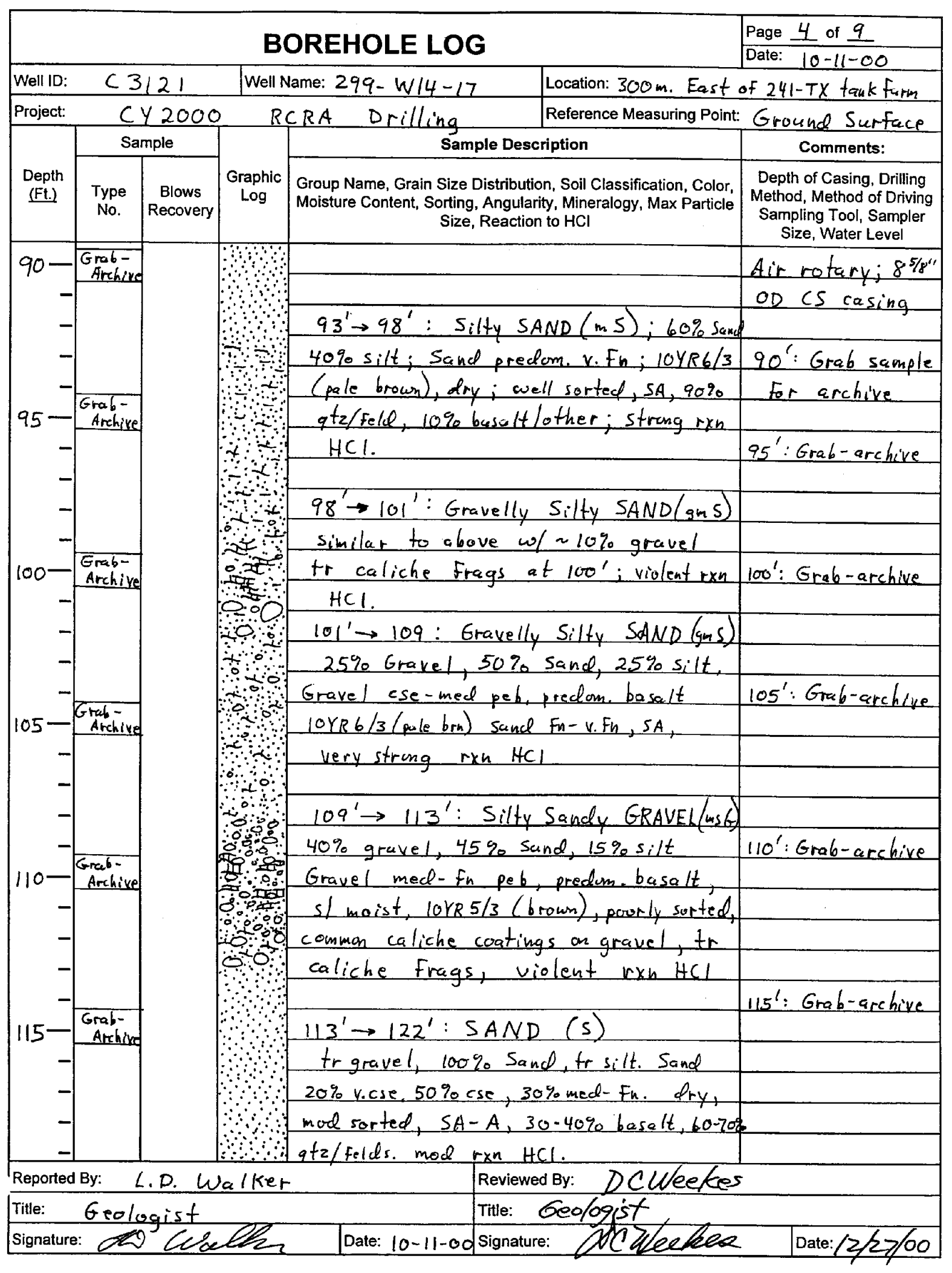

BHI-EE-183 (12/97) 


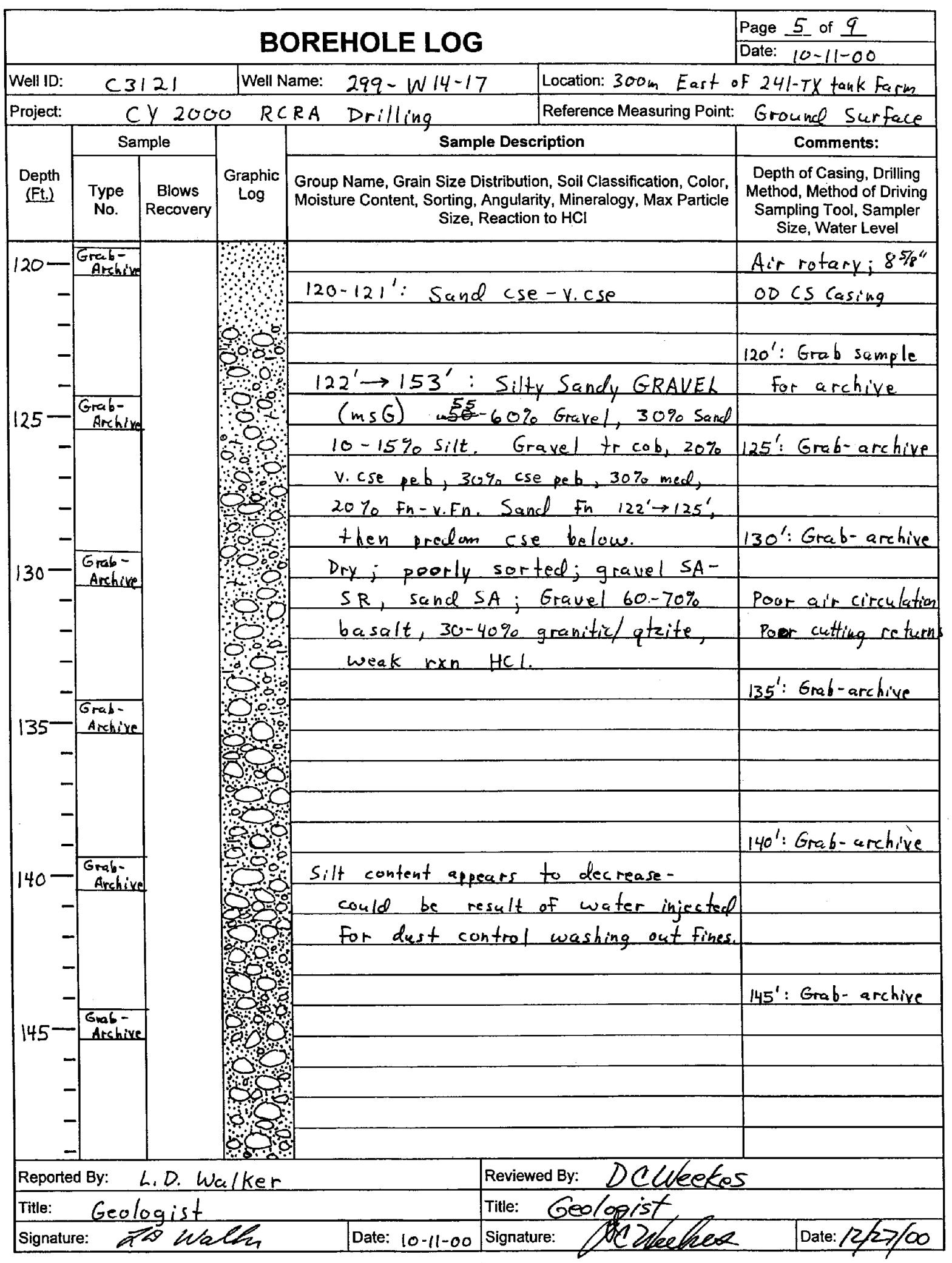

BHI-EE-183 (12/97) 


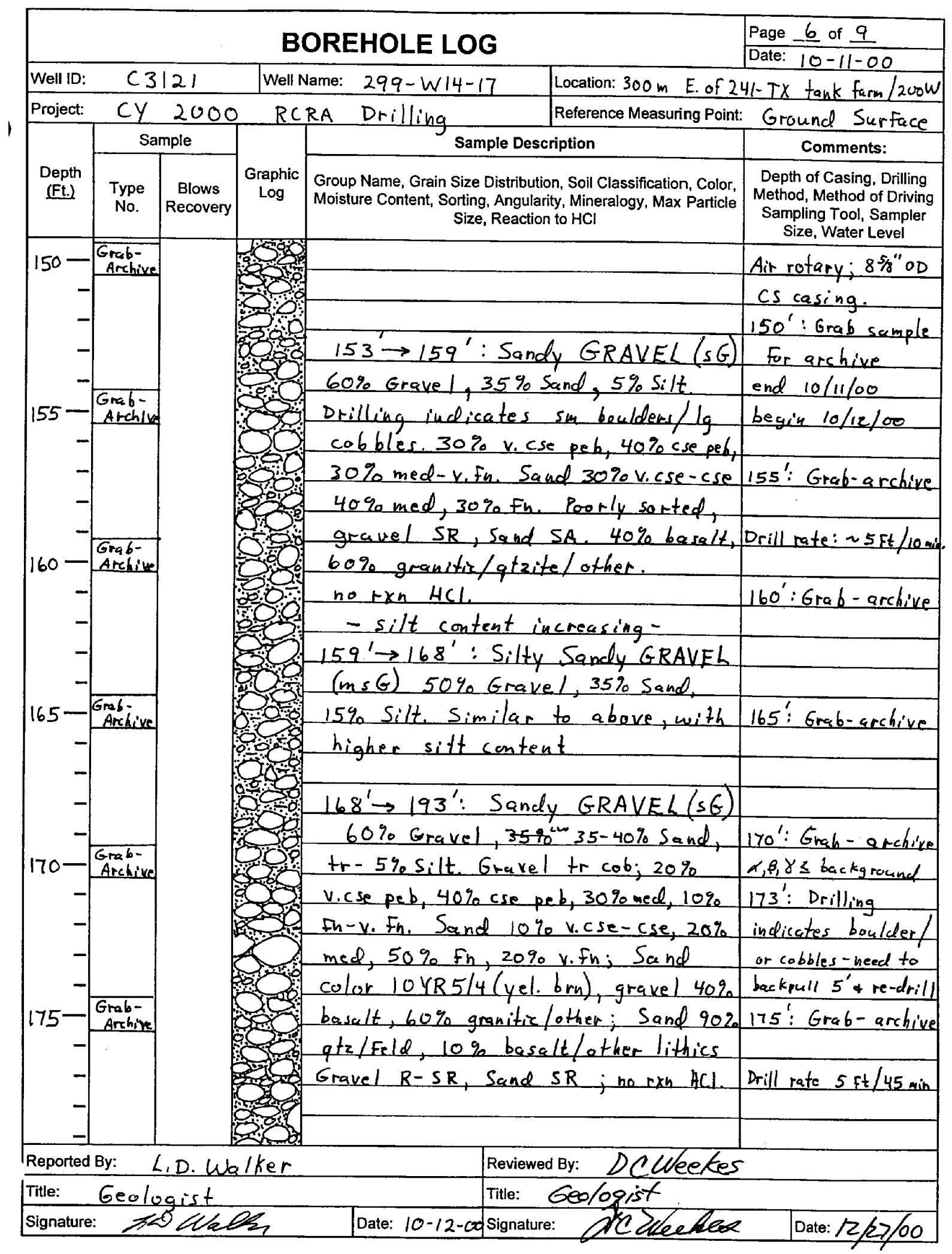

BHI-EE-183 (12/97) 


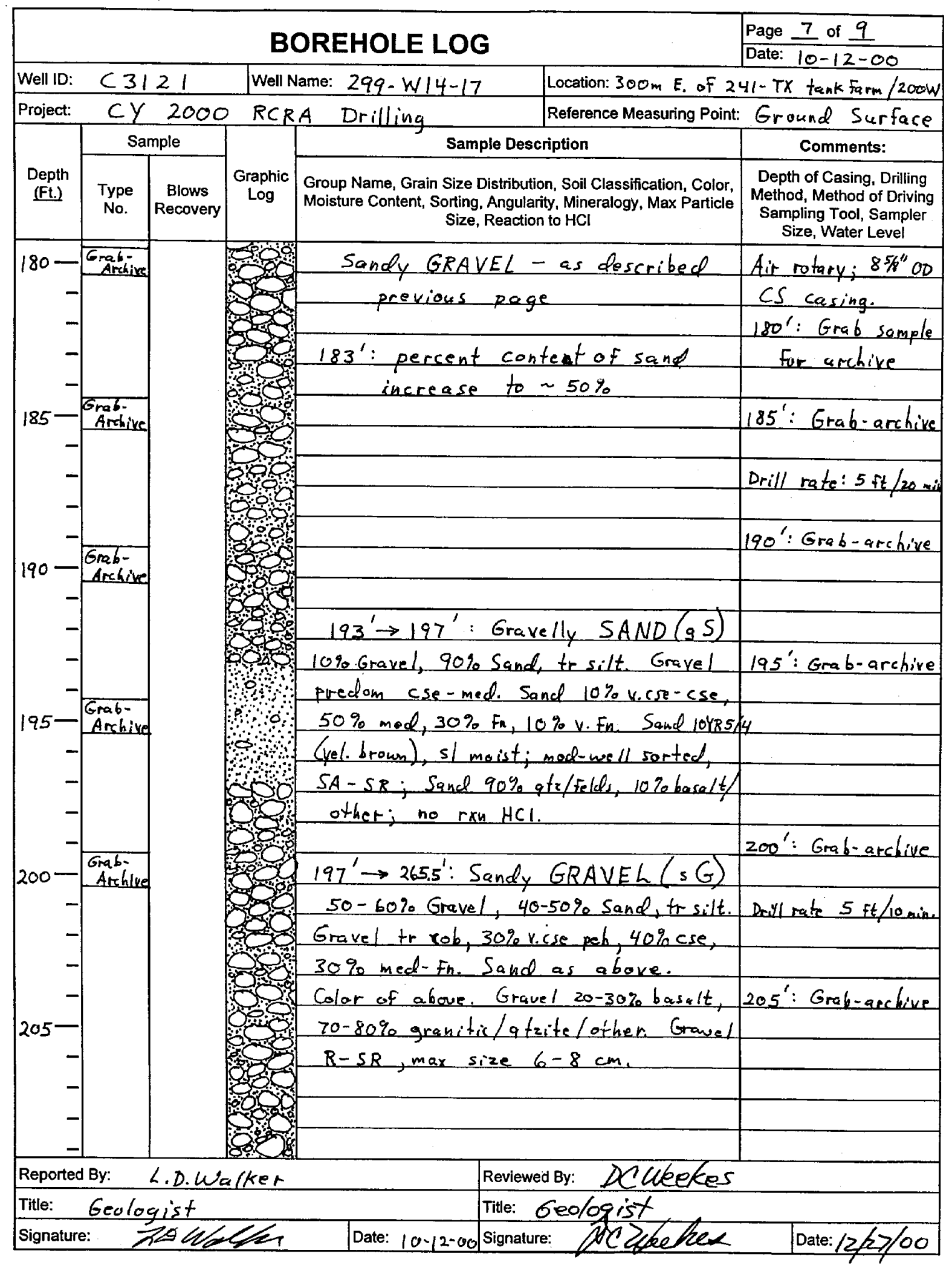

BHI-EE-183 (12/97) 


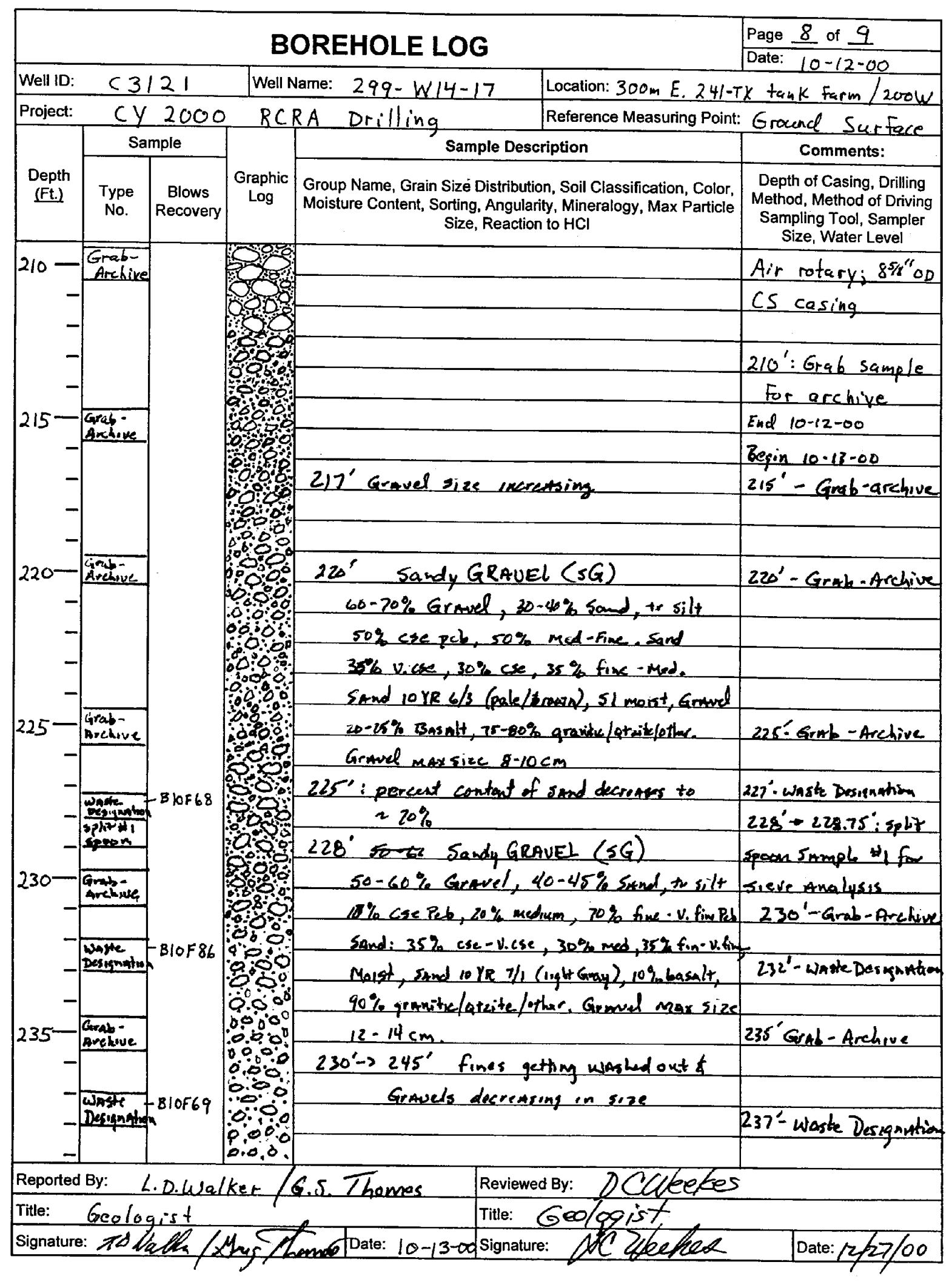

BHI-EE-183 (12/97) 


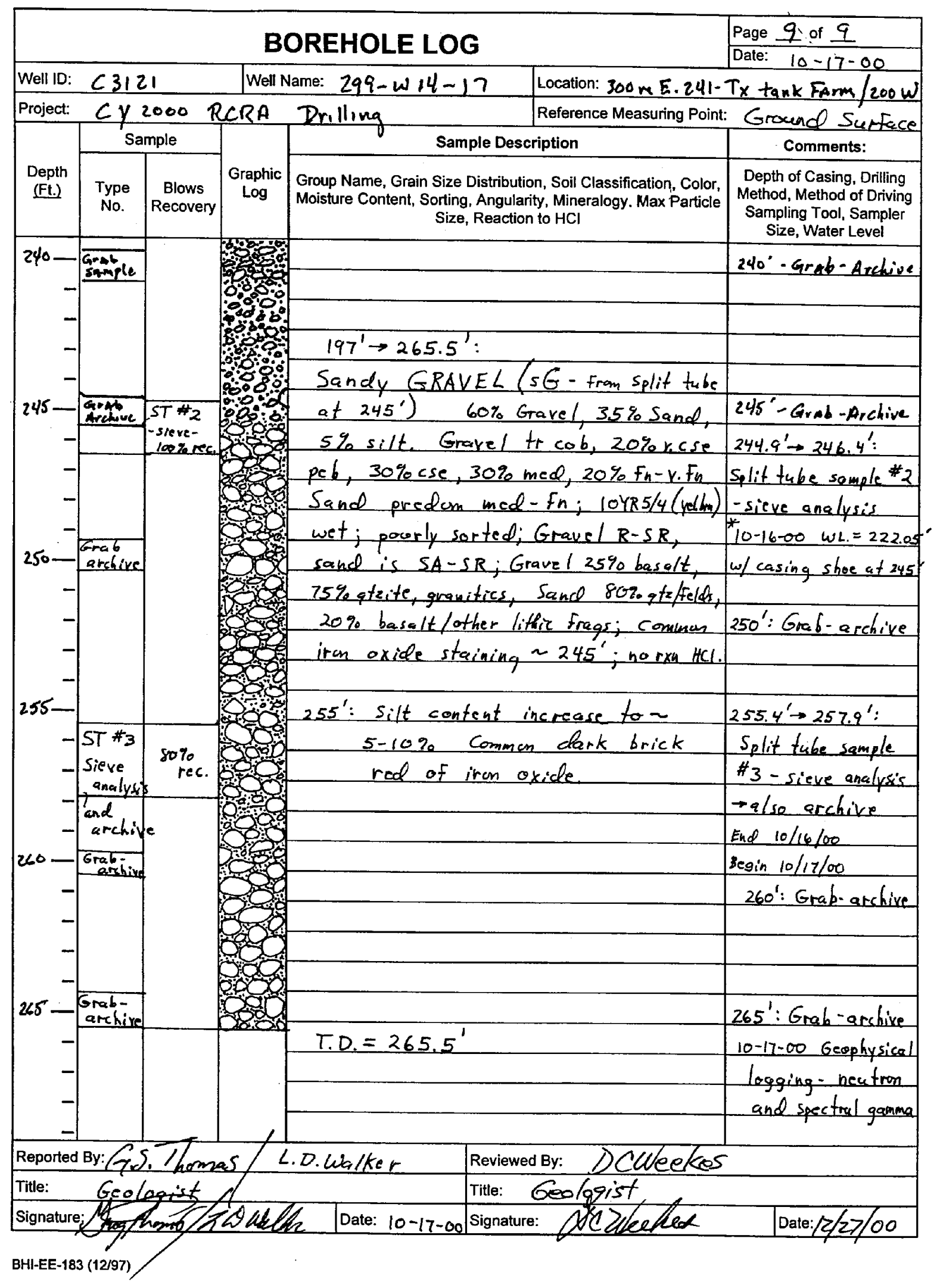




\section{WELL CONSTRUCTION SUMMARY REPORT}

$$
\begin{gathered}
\text { Start Date: } 11 / 30 / 00 \\
\hline \text { Finish Date: } 1 / 17 / 01 \\
\text { Page } 1 \text { of } 1 \\
\hline
\end{gathered}
$$

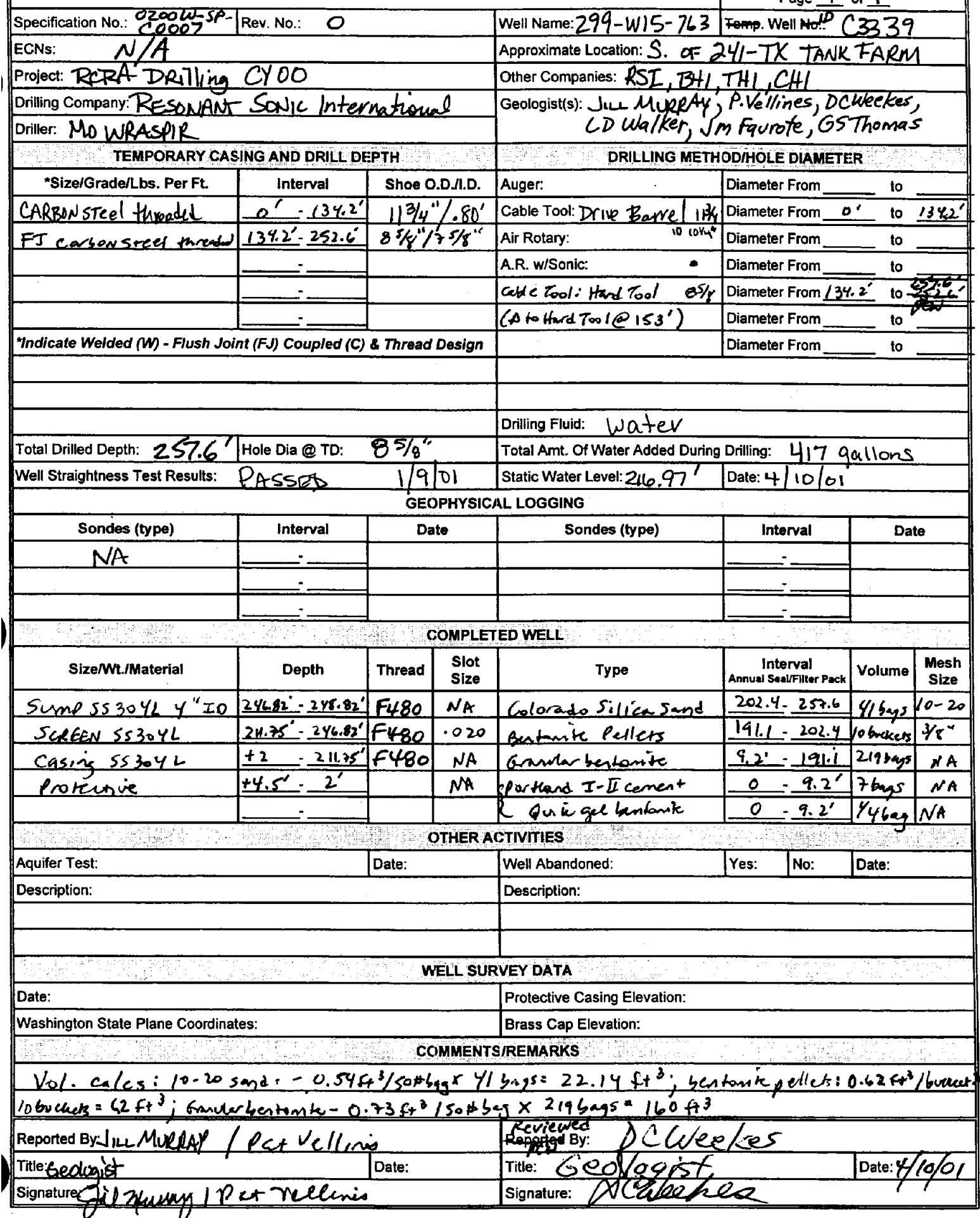

BHI-EE-181 (12/97) 


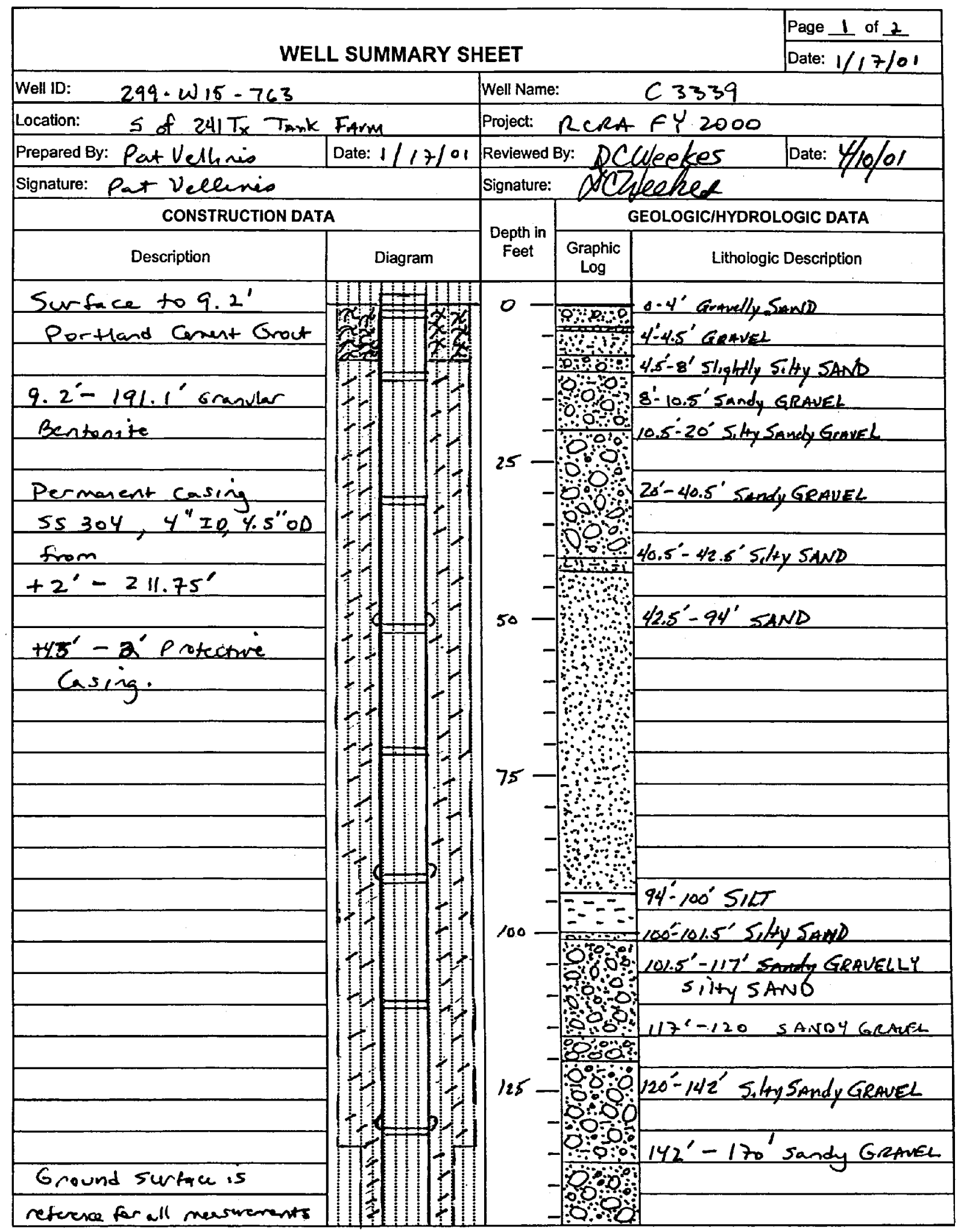

'H-EE-189 (12/97) 
WELL SUMMARY SHEET

Page 2 of 2 Date: $1 / 1 / 701$

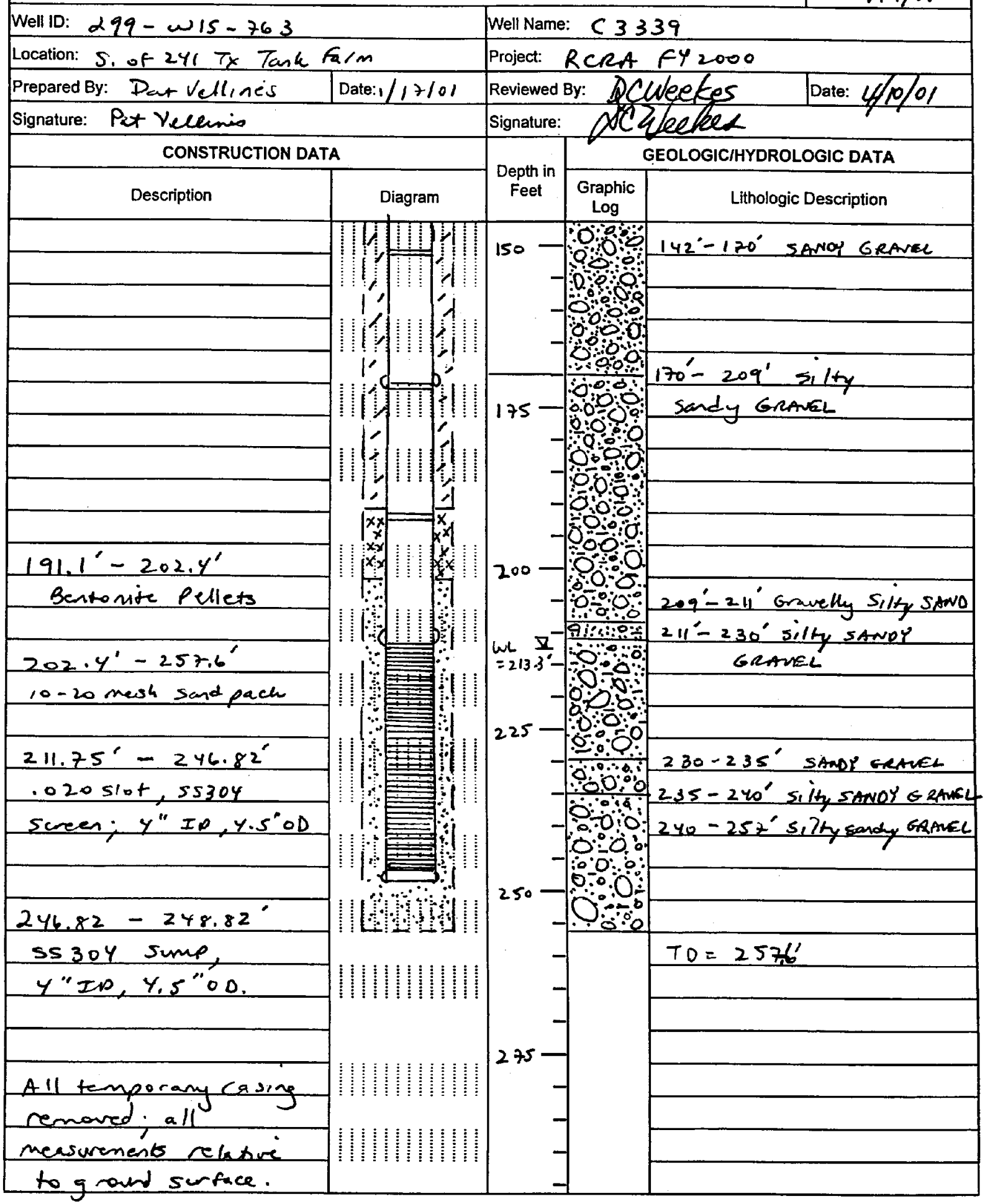

BHI-EE-189 (12/97) 


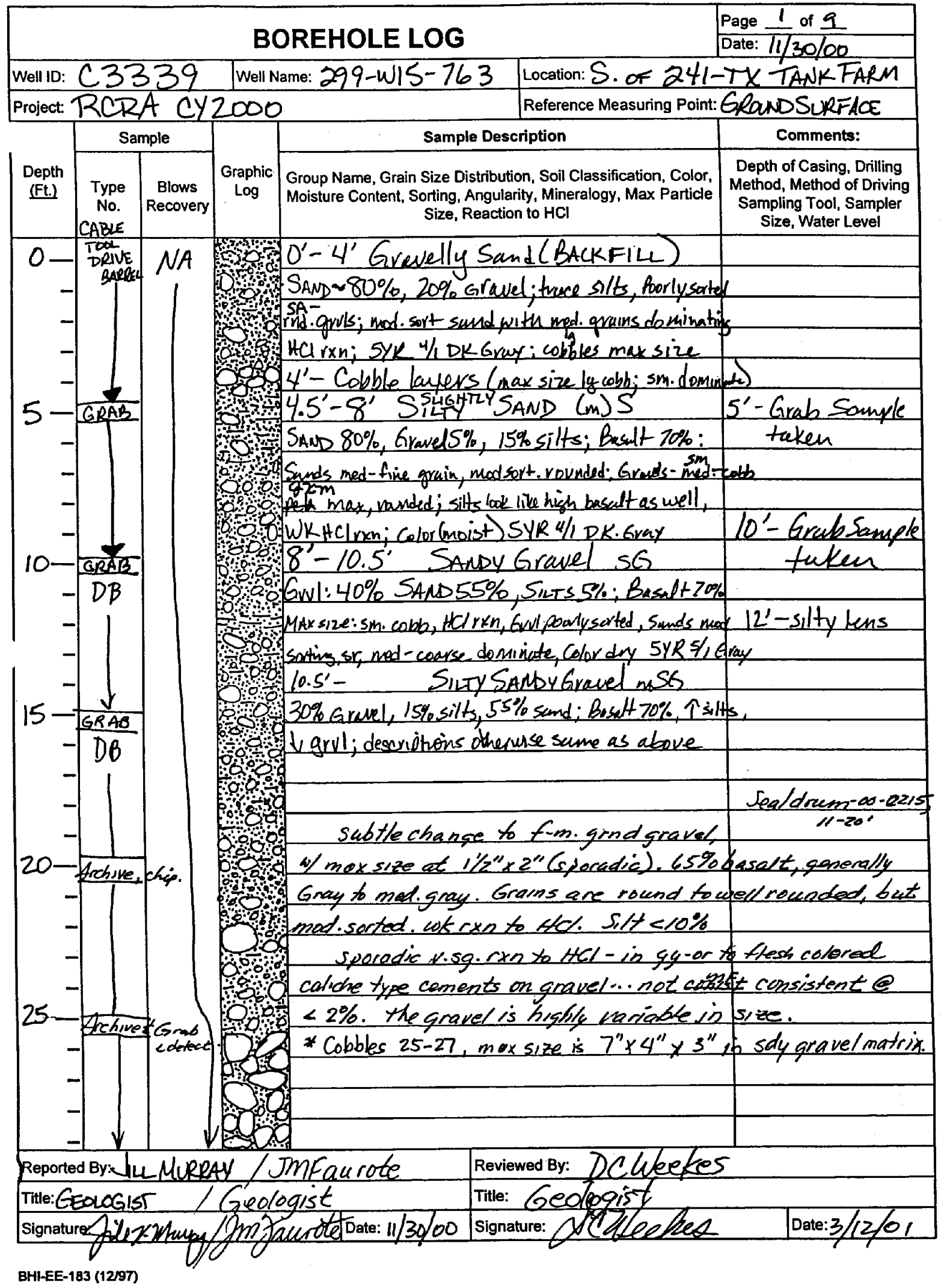




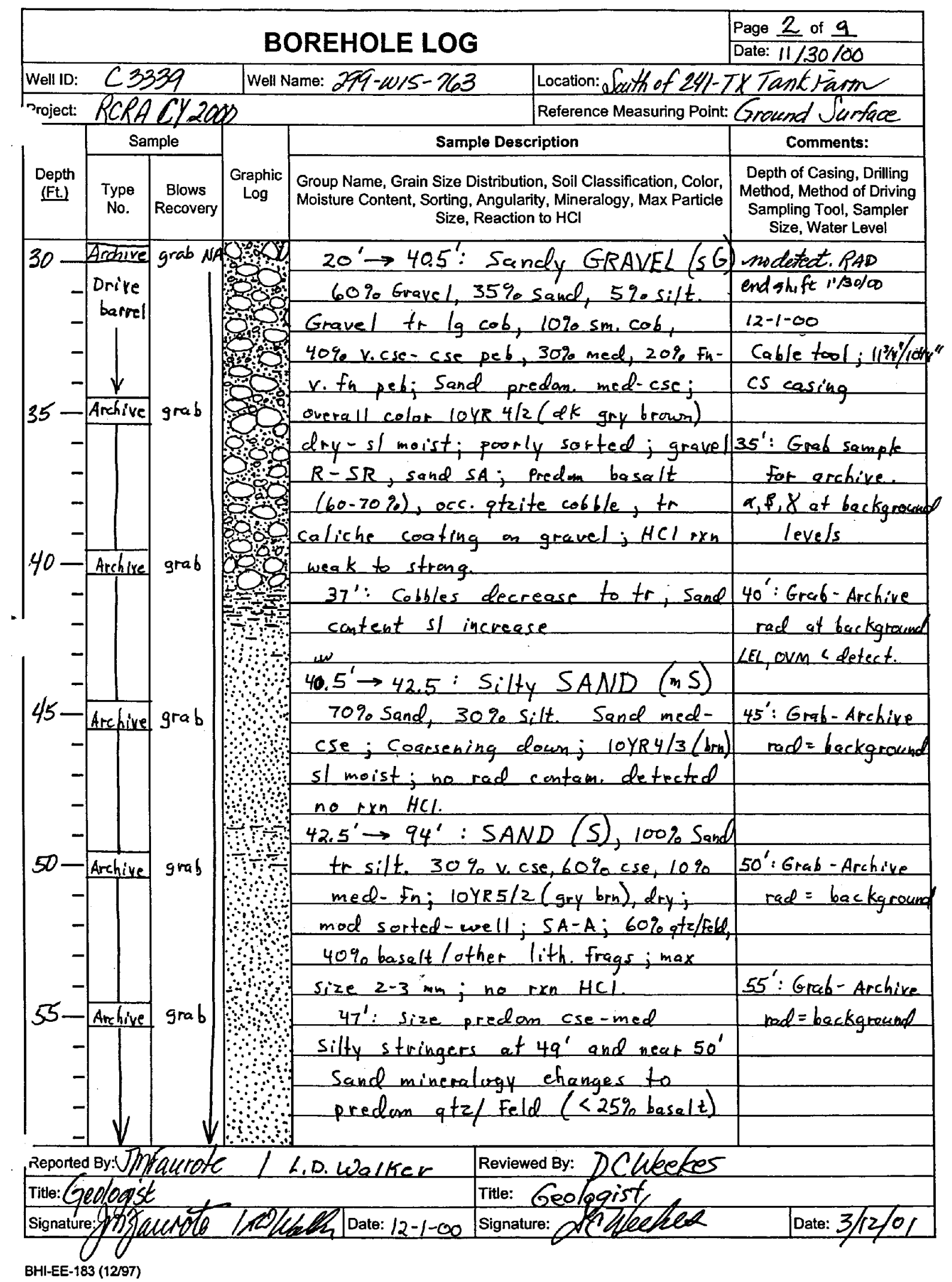




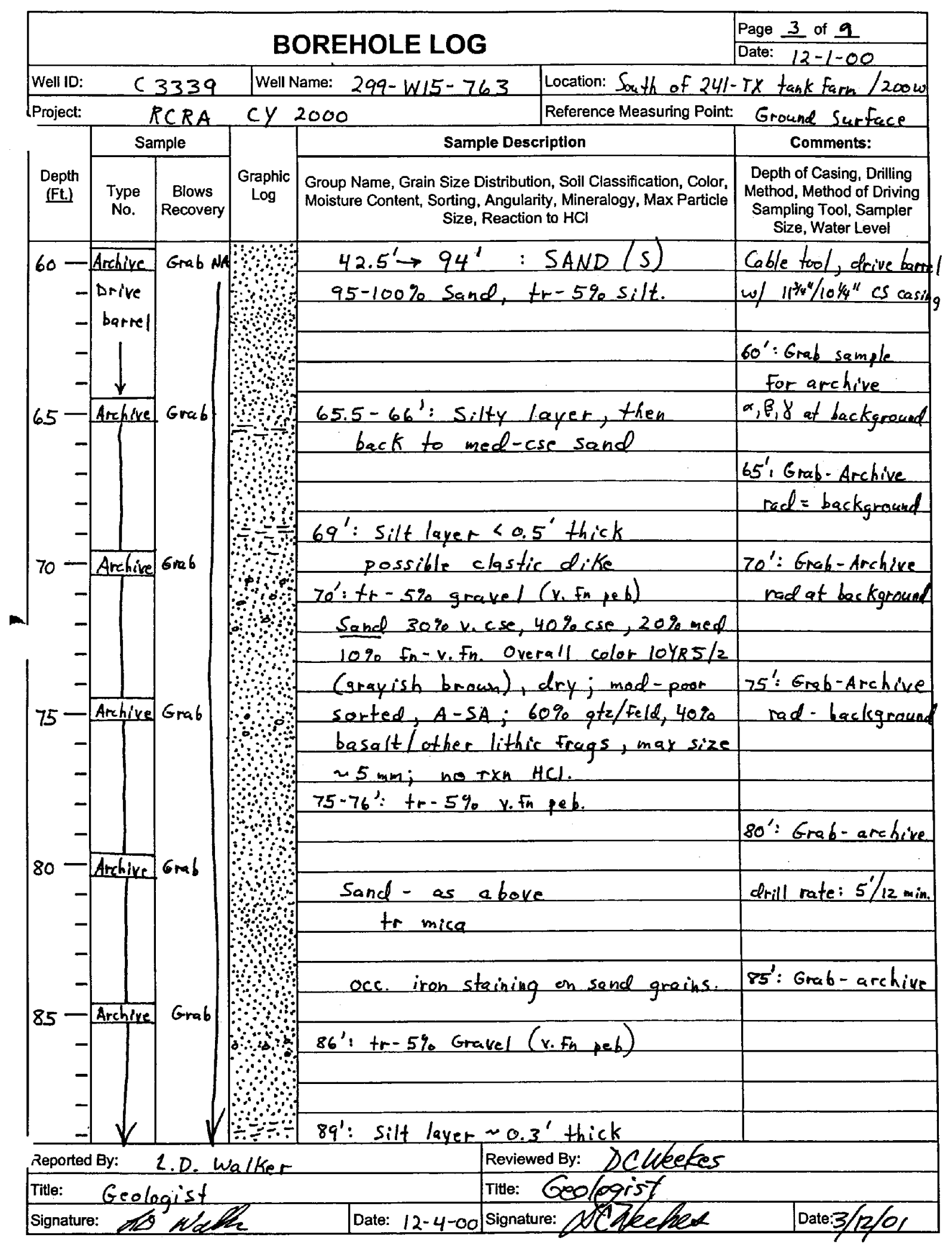

BHI-EE-183 (12/97) 


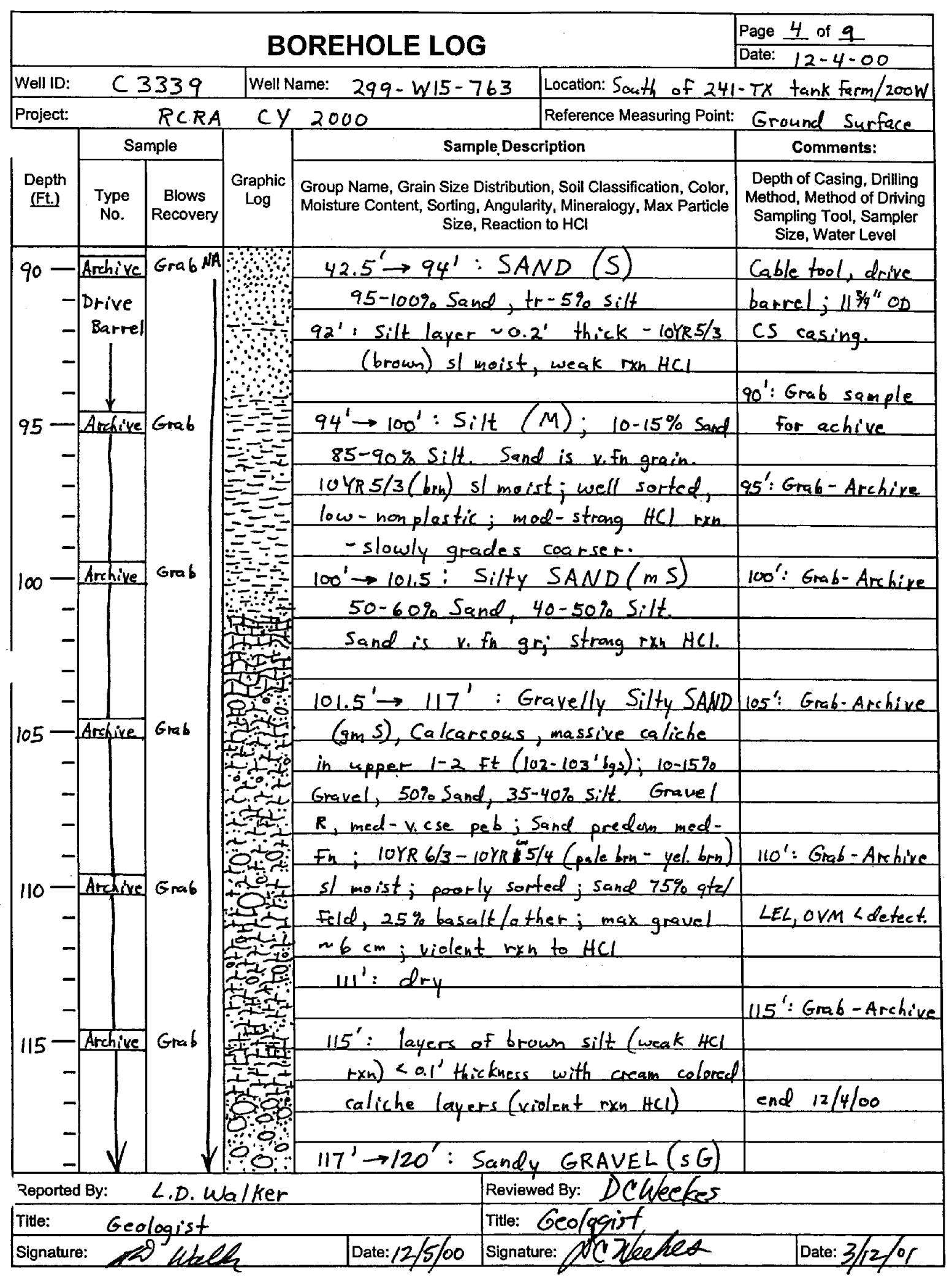

BHI-EE-183 (12/97) 


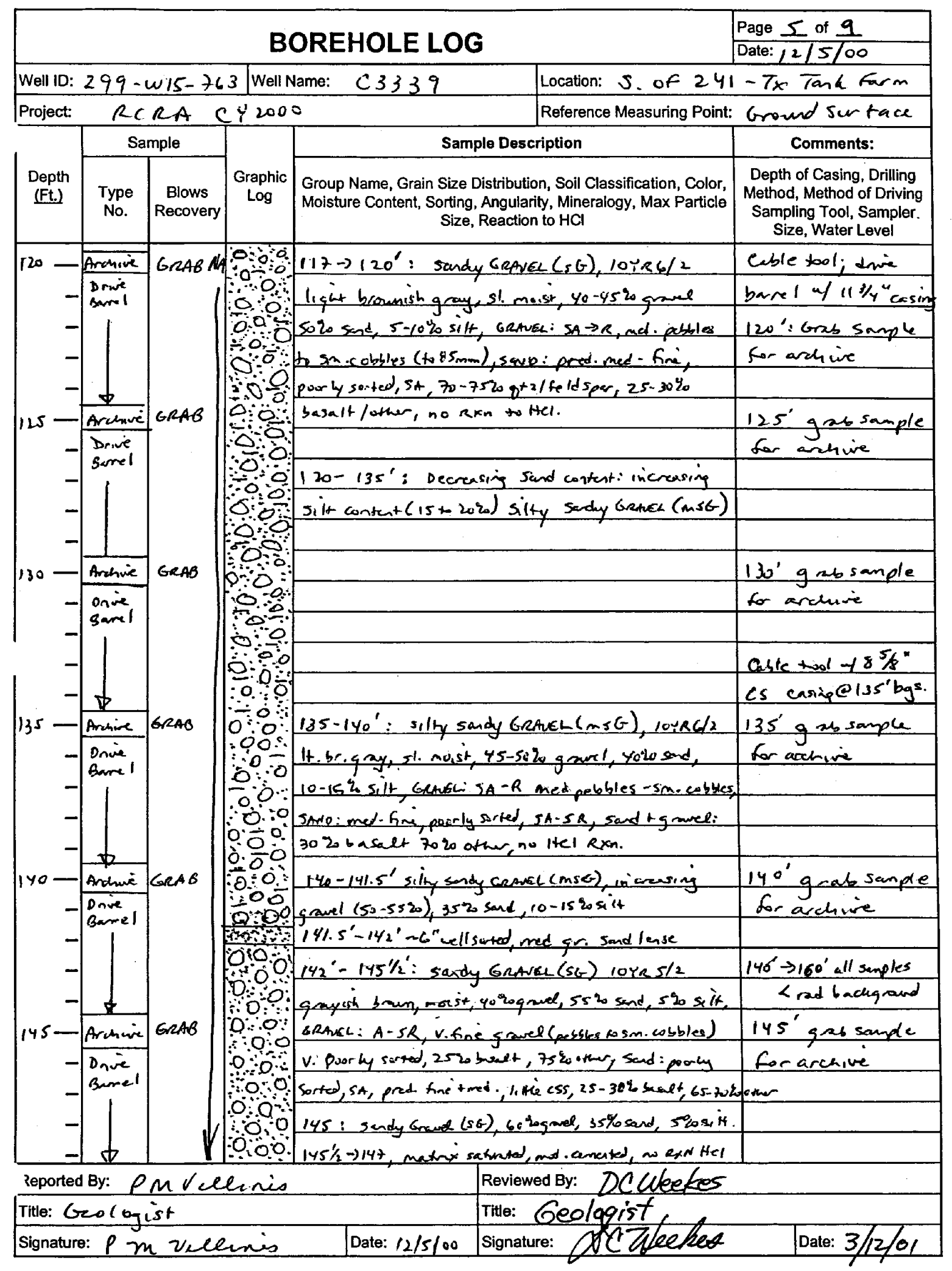

BHI-EE-183 (12/97) 


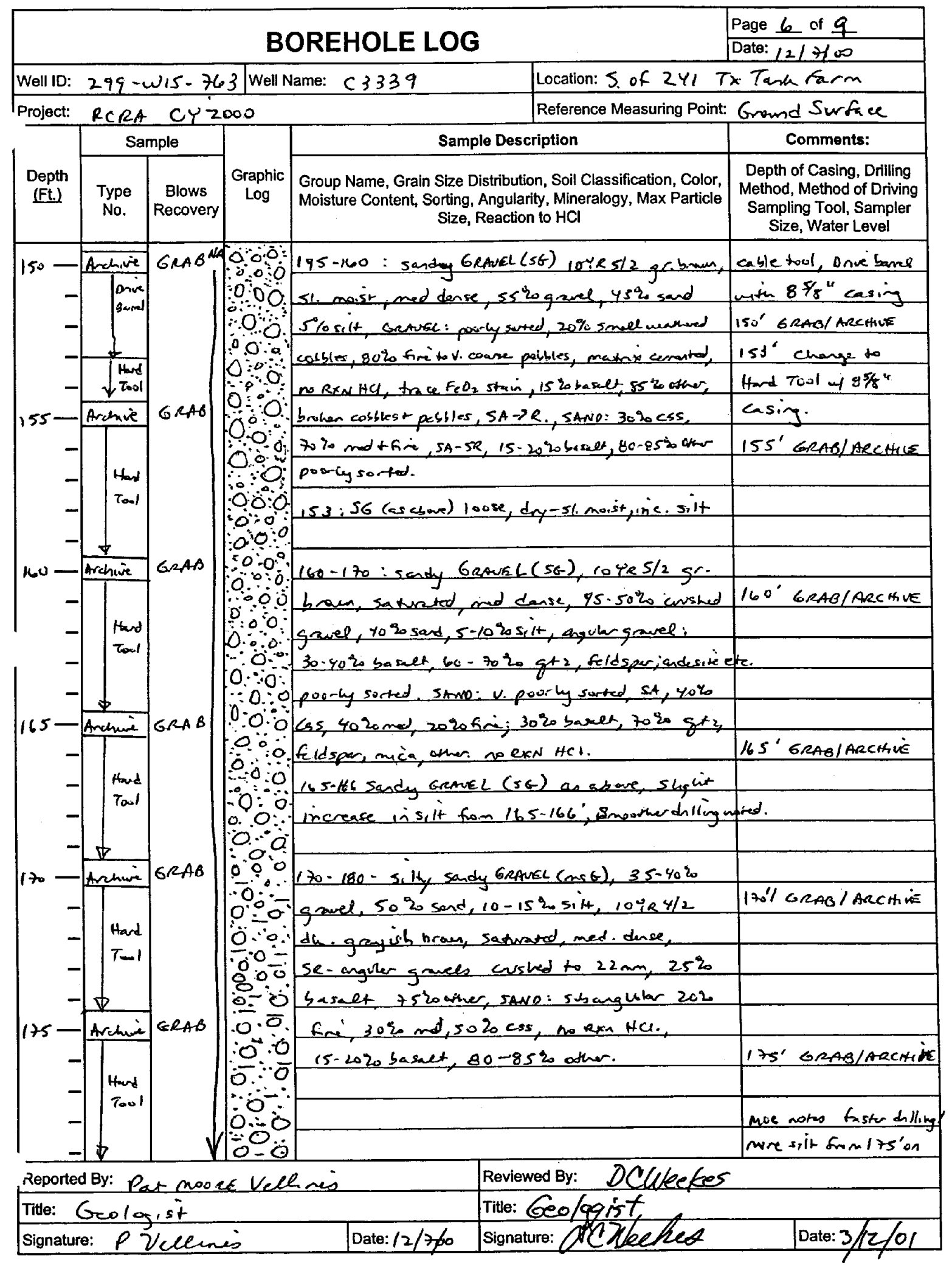

BHI-EE-183 (12/97) 


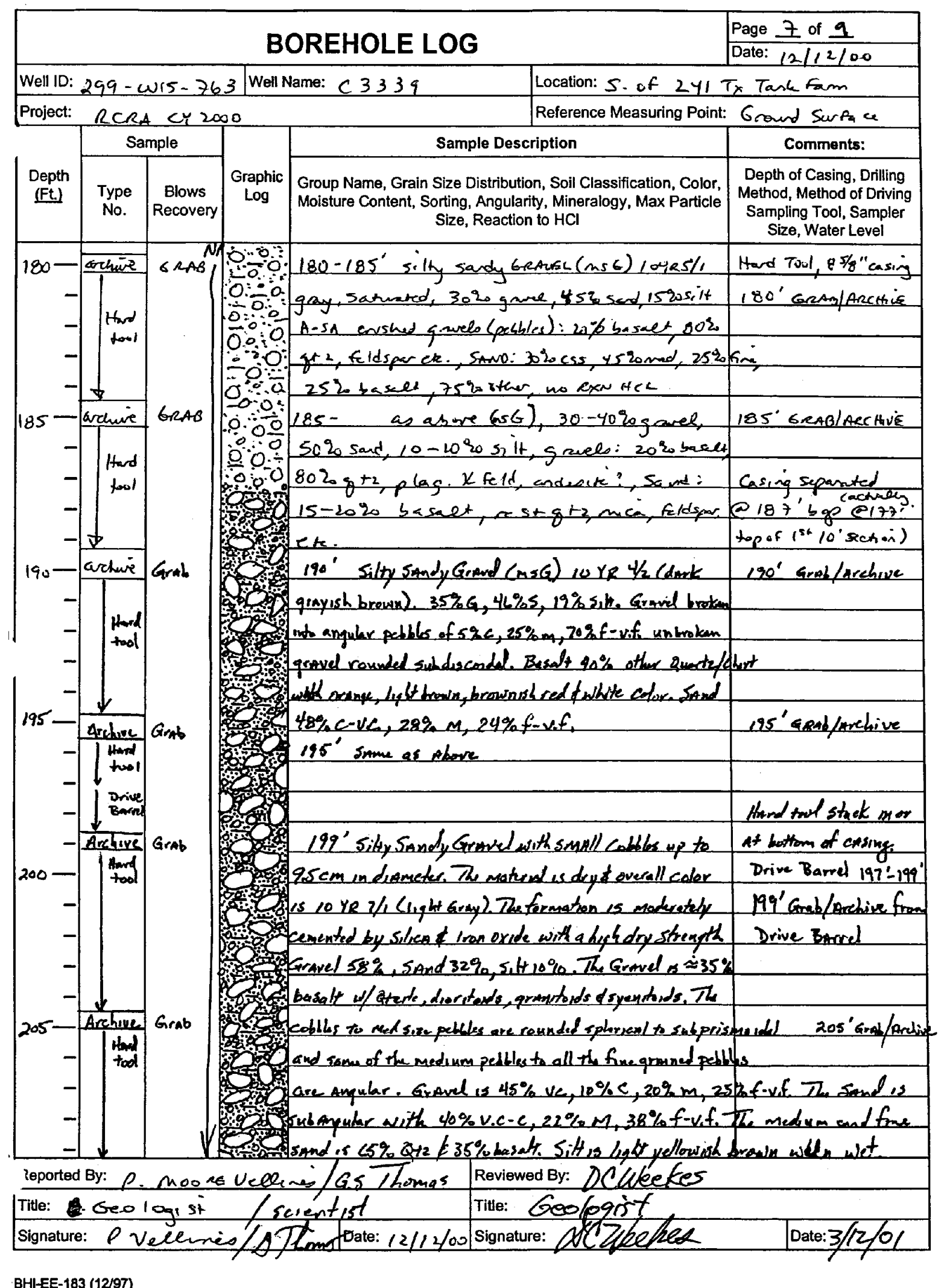




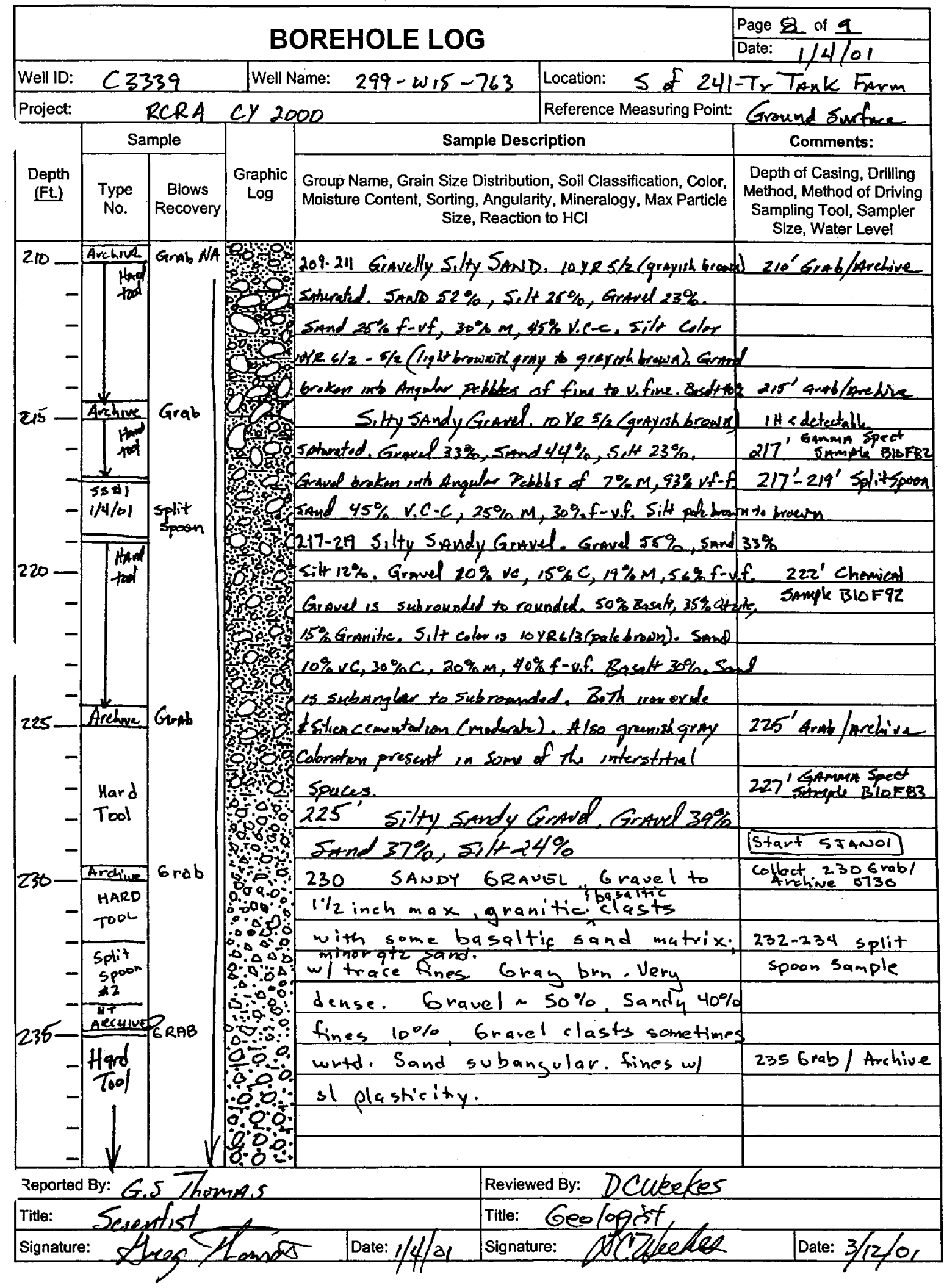

BHI-EE-183 (12/97) 


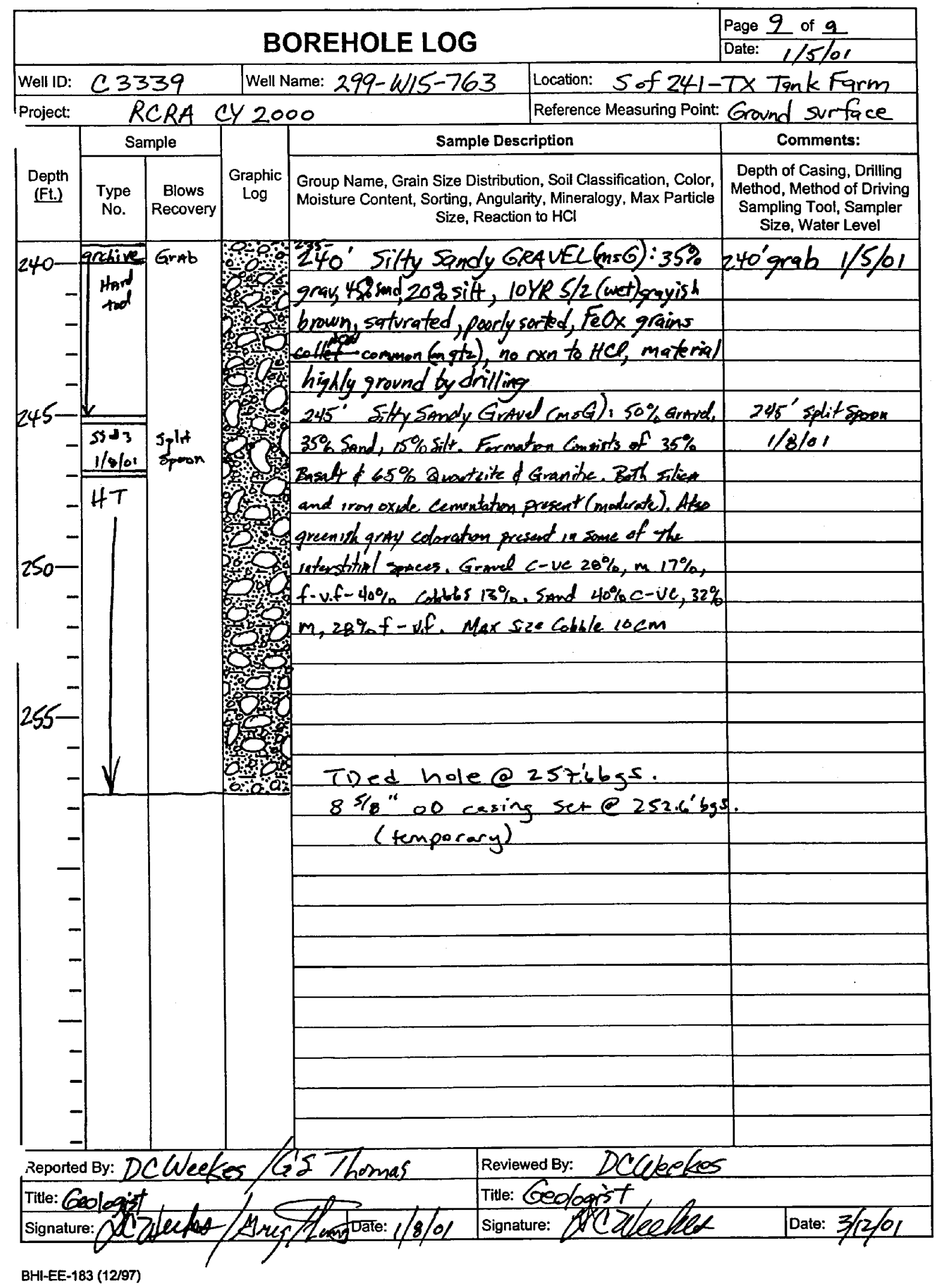




\section{Appendix B}

\section{Physical Property Data}


This Appendix includes the results of testing for particle size distribution on split spoon samples from the wells 299-W10-27, 299-W14-15, 299-W14-16, 299-W14-17, and 299-W15-763. The analyses were done by CH2M HILL Hanford Inc. using standard sieve techniques. 


\begin{tabular}{|c|c|c|c|c|c|c|}
\hline \multicolumn{7}{|c|}{$\begin{array}{c}\text { CH2M Hill Hantord, Inc. } \\
\text { SIEVE ANALYSIS }\end{array}$} \\
\hline \multirow{2}{*}{\begin{tabular}{|l} 
WELL NAME \\
TESTED BY \\
TESTE
\end{tabular}} & $299-W 10-27$ & DEPTH & $226.0^{\prime}-228.0^{\prime}$ & $\overline{\text { SAMPLE\# }}$ & W10-27-226.0 & \multirow{2}{*}{\begin{tabular}{|lr} 
WELL ID\# & C3125 \\
DATE & $03 / 23 / 2001$ \\
\end{tabular}} \\
\hline & John Wimett & CONTACT & Dave Weekes & PHONE & $372-9130$ & \\
\hline \begin{tabular}{|l} 
SAMPLE \\
WT (g) \\
\end{tabular} & $\begin{array}{l}\text { SIEVE } \\
\text { SIZE IN. }\end{array}$ & $\begin{array}{l}\text { CUMULATIVE } \\
\text { WEIGHT(g) }\end{array}$ & $\begin{array}{l}\text { \% WEIGHT } \\
\text { RETAINED }\end{array}$ & $\begin{array}{c}\% \\
\text { PASSING }\end{array}$ & $\begin{array}{c}\text { Grain Size } \\
(\mathrm{mm})\end{array}$ & COMMENTS \\
\hline 847.10 & $2 "$ & 0.0 & 0.0 & 100.0 & 50.80 & \\
\hline & $1.5^{\prime \prime}$ & 62.8 & 7.4 & 92.6 & 38.10 & \\
\hline & $3 / 4^{\prime \prime}$ & 249.0 & 29.4 & 70.6 & 19.05 & \\
\hline & $3 / 8^{\prime \prime}$ & 335.2 & 39.6 & 60.4 & 9.42 & \\
\hline & $\# 4$ & 405.6 & 47.9 & 52.1 & 4.70 & \\
\hline & $\# 10$ & 494.5 & 58.4 & 41.6 & 1.98 & \\
\hline & $\# 20$ & 567.6 & 67.0 & 33.0 & 0.83 & \\
\hline & $\# 40$ & 612.4 & 72.3 & 27.7 & 0.42 & \\
\hline & $\# 60$ & 659.4 & 77.8 & 22.2 & 0.25 & \\
\hline & $\# 100$ & 702.9 & 83.0 & 17.0 & 0.150 & \\
\hline & $\# 200$ & 746.6 & 88.1 & 11.9 & 0.074 & \\
\hline
\end{tabular}

Sieve Analysis Data for Sample W10-27-226.0

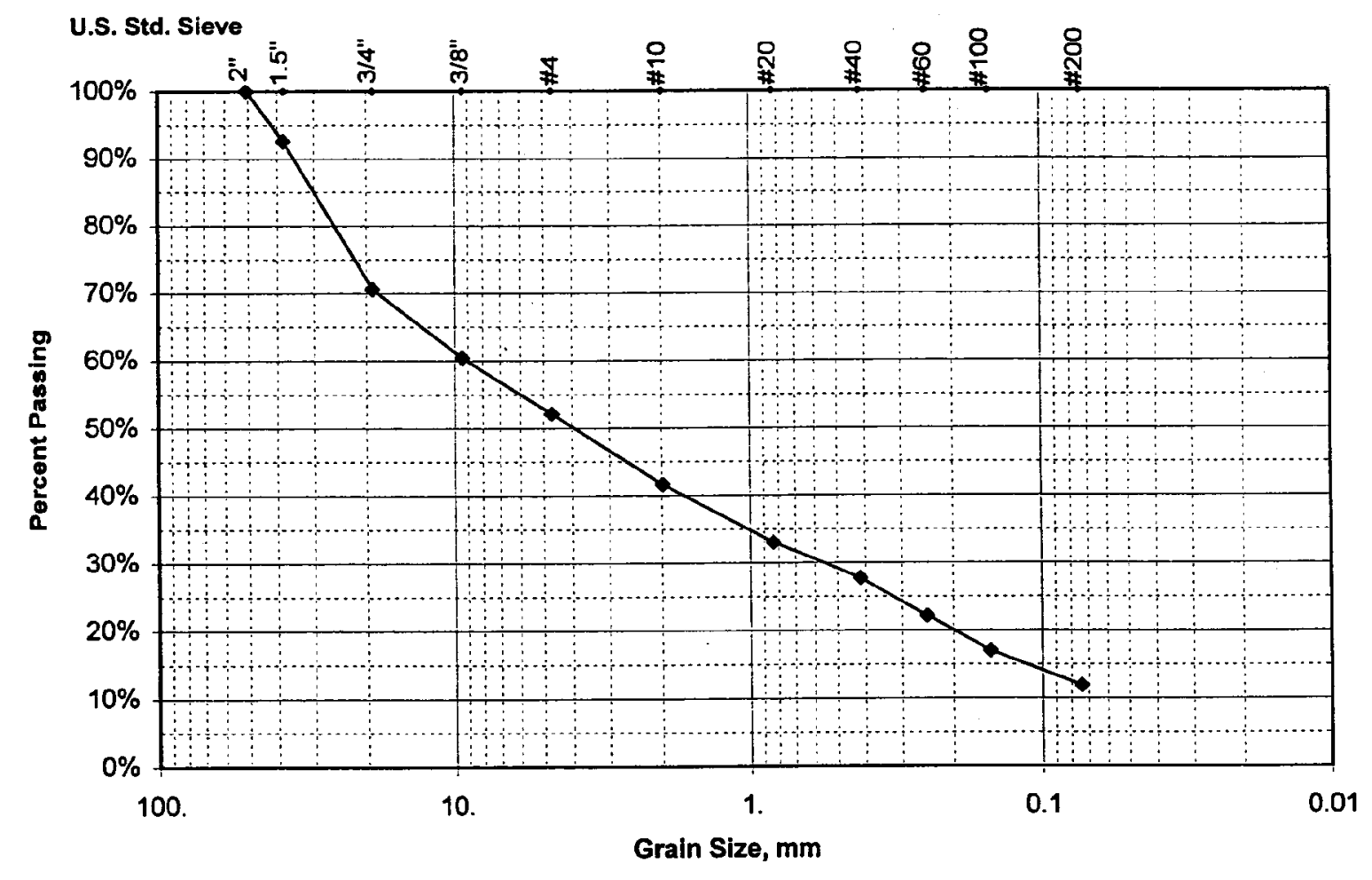

Comments: Silty Sandy Gravel

All data are accurat ly and completely recorded.

Checked By: AC Tleepex.

Date: $4 / 3 / 0$

B. 2 


\begin{tabular}{|c|c|c|c|c|c|c|}
\hline \multicolumn{7}{|c|}{ CH2M Hill Hantord, Inc. } \\
\hline \multirow{2}{*}{$\begin{array}{l}\text { WELL NAME } \\
\text { TESTED BY }\end{array}$} & 299-W10-27 & DEPTH & $241.0^{\prime}-242.0^{\prime}$ & SAMPLE\# & W10-27-241.0 & \multirow{2}{*}{\begin{tabular}{|lr} 
WELL ID\# & C3125 \\
DATE & $03 / 23 / 2001$ \\
\end{tabular}} \\
\hline & John Wimett & CONTACT & Dave Weekes & PHONE & $372-9130$ & \\
\hline \multirow{2}{*}{\begin{tabular}{|l}
$\begin{array}{l}\text { SAMPLE } \\
\text { WT (g) }\end{array}$ \\
810.30 \\
\end{tabular}} & $\begin{array}{c}\text { SIEVE } \\
\text { SIZE IN. }\end{array}$ & $\begin{array}{c}\text { CUMULATIVE } \\
\text { WEIGHT(g) }\end{array}$ & $\begin{array}{l}\% \text { WEIGHT } \\
\text { RETAINED } \\
\end{array}$ & $\begin{array}{c}\% \\
\text { PASSING } \\
\end{array}$ & $\begin{array}{c}\text { Grain Size } \\
(\mathrm{mm})\end{array}$ & COMMENTS \\
\hline & $2 "$ & 0.0 & 0.0 & 100.0 & 50.80 & \\
\hline & $1.5^{\prime \prime}$ & 0.0 & 0.0 & 100.0 & 38.10 & \\
\hline & $3 / 4^{\prime \prime}$ & 96.3 & 11.9 & 88.1 & 19.05 & \\
\hline & $3 / 8^{\prime \prime}$ & 176.2 & 21.7 & 78.3 & 9.42 & \\
\hline & $\# 4$ & 264.5 & 32.6 & 67.4 & 4.70 & \\
\hline & $\# 10$ & 357.2 & 44.1 & 55.9 & 1.98 & \\
\hline & $\# 20$ & 449.1 & 55.4 & 44.6 & 0.83 & \\
\hline & $\# 40$ & 510.5 & 63.0 & 37.0 & 0.42 & \\
\hline & $\# 60$ & 572.4 & 70.6 & 29.4 & 0.25 & \\
\hline & $\# 100$ & 626.5 & 77.3 & 22.7 & 0.150 & \\
\hline & $\# 200$ & 682.7 & 84.3 & 15.7 & 0.074 & \\
\hline
\end{tabular}

\section{Sieve Analysis Data for Sample W10-27-241.0}

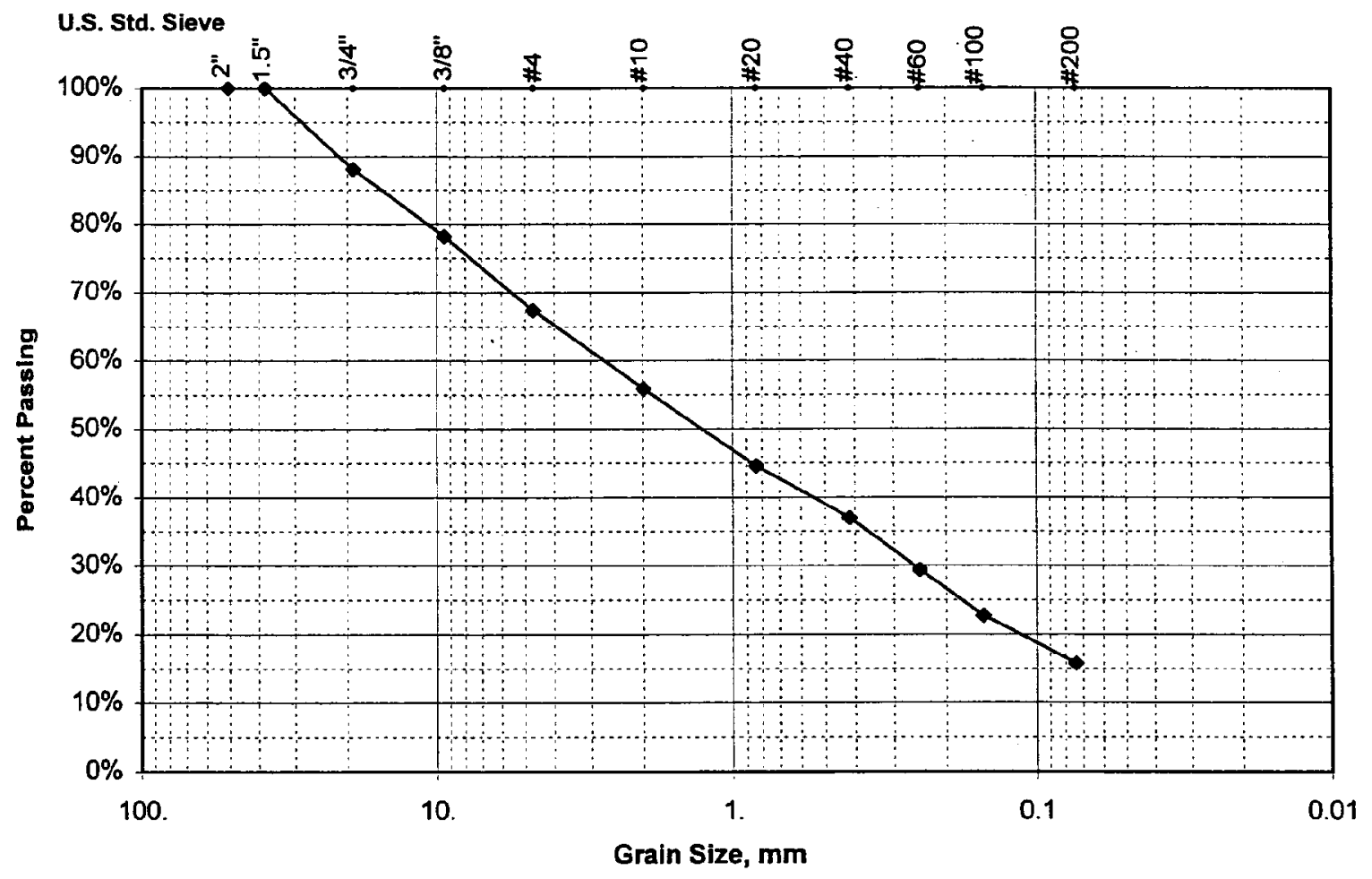

Comments: Silty Sandy Gravel

All data are accurate $y$ and completely recorded. Checked By: 201 leetere $4 / 3 / 01$

B.3 


\begin{tabular}{|c|c|c|c|c|c|c|}
\hline \multicolumn{7}{|c|}{$\begin{array}{l}\text { CH2M HIII Hanford, Inc. } \\
\text { SIEVE ANALYSIS }\end{array}$} \\
\hline WELL NAME & 299-W10-27 & DEPTH & $254.0^{\prime}-256.0^{\prime}$ & SAMPLE\# & W10-27-254.0 & WELLID\# \\
\hline TESTED BY & John Wimett & CONTACT & Dave Weekes & PHONE & $372-9130$ & $03 / 23 / 2001$ \\
\hline $\begin{array}{l}\text { SAMPLE } \\
W T(g)\end{array}$ & $\begin{array}{c}\text { SIEVE } \\
\text { SIZE IN. }\end{array}$ & $\begin{array}{l}\text { CUMULATIVE } \\
\text { WEIGHT(g) }\end{array}$ & $\begin{array}{l}\text { \% WEIGHT } \\
\text { RETAINED }\end{array}$ & $\begin{array}{c}\% \\
\text { PASSING }\end{array}$ & $\begin{array}{c}\text { Grain Size } \\
(\mathrm{mm})\end{array}$ & COMMENTS \\
\hline 976.10 & $2^{\prime \prime}$ & 0.0 & 0.0 & 100.0 & 50.80 & \\
\hline & $1.5^{\prime \prime}$ & 0.0 & 0.0 & 100.0 & 38.10 & \\
\hline & $3 / 4 "$ & 319.3 & 32.7 & 67.3 & 19.05 & \\
\hline & $3 / 8^{\prime \prime}$ & 525.3 & 53.8 & 46.2 & 9.42 & \\
\hline & \#4 & 618.2 & 63.3 & 36.7 & 4.70 & \\
\hline & $\# 10$ & 683.3 & 70.0 & 30.0 & 1.98 & \\
\hline & $\# 20$ & 722.0 & 74.0 & 26.0 & 0.83 & \\
\hline & $\# 40$ & 760.4 & 77.9 & 22.1 & 0.42 & \\
\hline & $\# 60$ & 846.2 & 86.7 & 13.3 & 0.25 & \\
\hline & $\# 100$ & 882.3 & 90.4 & 9.6 & 0.150 & \\
\hline & $\# 200$ & 908.8 & 93.1 & 6.9 & 0.074 & \\
\hline
\end{tabular}

Sieve Analysis Data for Sample W10-27-254.0

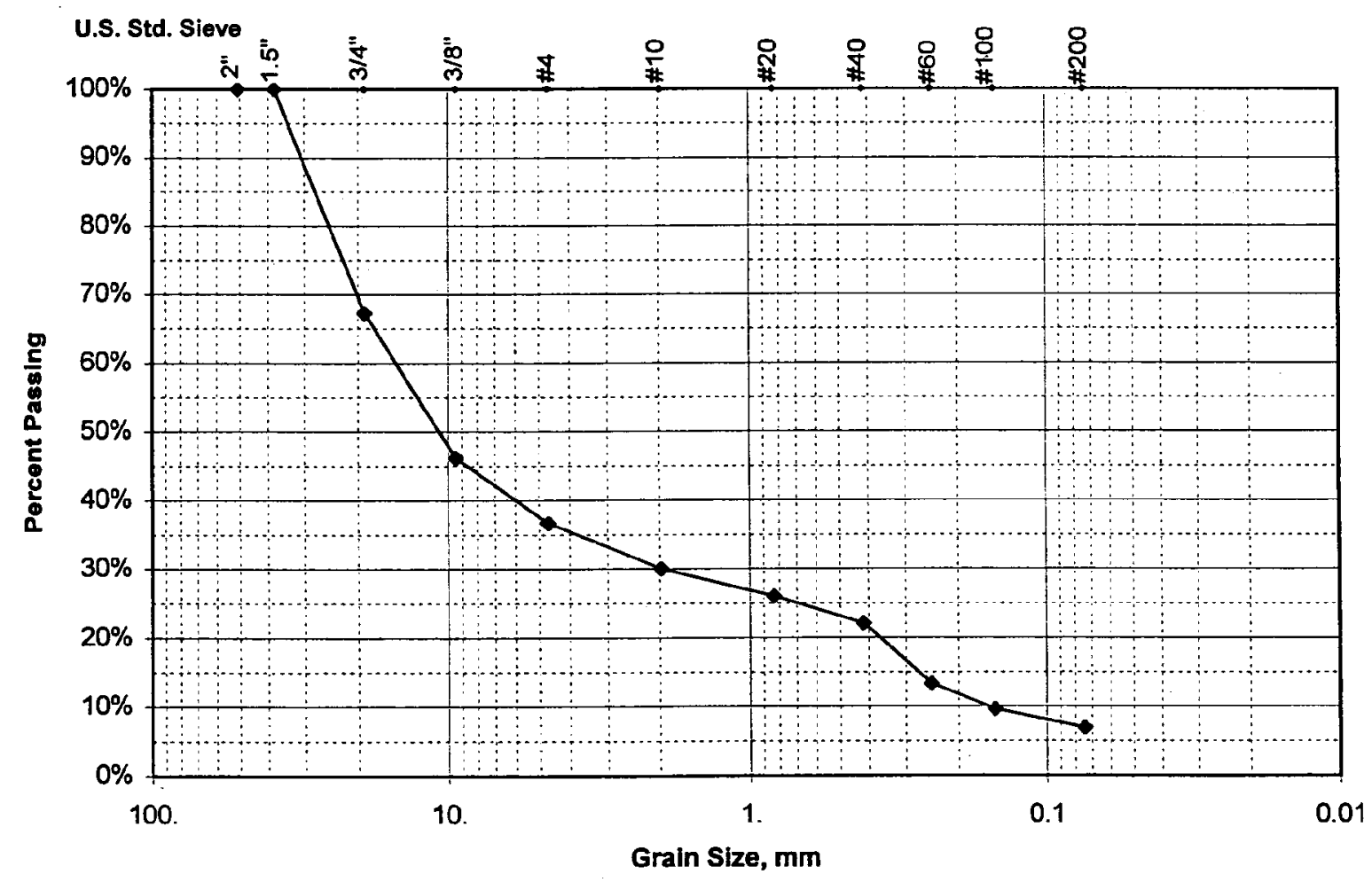

Comments: Sandy Gravel

All data are accurately and completely recorded. Checked By: peofeeper Date: $4 / 3 / 01$ 


\section{CH2MHili Hanford, Inc.}

SIEVE ANALYSIS

\begin{tabular}{|c|c|c|c|c|c|c|}
\hline WELL NAME & 299-W14-15 & DEPTH & $222.2^{\prime}-224.5^{\prime}$ & SAMPLE\# & W14-15-222.2 & WELL ID\# \\
\hline TESTED BY & JMW & CONTACT & Dave Weekes & PHONE & $372-9524$ & $08 / 31 / 2000$ \\
\hline $\begin{array}{l}\text { SAMPLE } \\
W T(g)\end{array}$ & $\begin{array}{c}\text { SIEVE } \\
\text { SIZE IN. }\end{array}$ & $\begin{array}{c}\text { CUMULATIVE } \\
\text { WEIGHT(g) } \\
\end{array}$ & $\begin{array}{l}\text { \% WEIGHT } \\
\text { RETAINED }\end{array}$ & $\begin{array}{c}\% \\
\text { PASSING } \\
\end{array}$ & $\begin{array}{c}\text { Grain Size } \\
(\mathrm{mm})\end{array}$ & COMMENTS \\
\hline \multirow[t]{11}{*}{829.90} & $2 "$ & 0.0 & 0.0 & 100.0 & 50.80 & \\
\hline & $1.5^{\prime \prime}$ & 0.0 & 0.0 & 100.0 & 38.10 & \\
\hline & $3 / 4^{\prime \prime}$ & 84.7 & 10.2 & 89.8 & 19.05 & \\
\hline & $3 / 8^{\prime \prime}$ & 212.7 & 25.6 & 74.4 & 9.42 & \\
\hline & $\# 4$ & 325.8 & 39.3 & 60.7 & 4.70 & \\
\hline & $\# 10$ & 414.0 & 49.9 & 50.1 & 1.98 & \\
\hline & $\# 20$ & 476.4 & 57.4 & 42.6 & 0.83 & \\
\hline & $\# 40$ & 515.0 & 62.1 & 37.9 & 0.42 & \\
\hline & $\# 60$ & 578.6 & 69.7 & 30.3 & 0.25 & \\
\hline & $\# 100$ & 634.9 & 76.5 & 23.5 & 0.150 & \\
\hline & \#200 & 689.0 & 83.0 & 17.0 & 0.074 & \\
\hline
\end{tabular}

Sieve Analysis Data for Sample W14-15-222.2

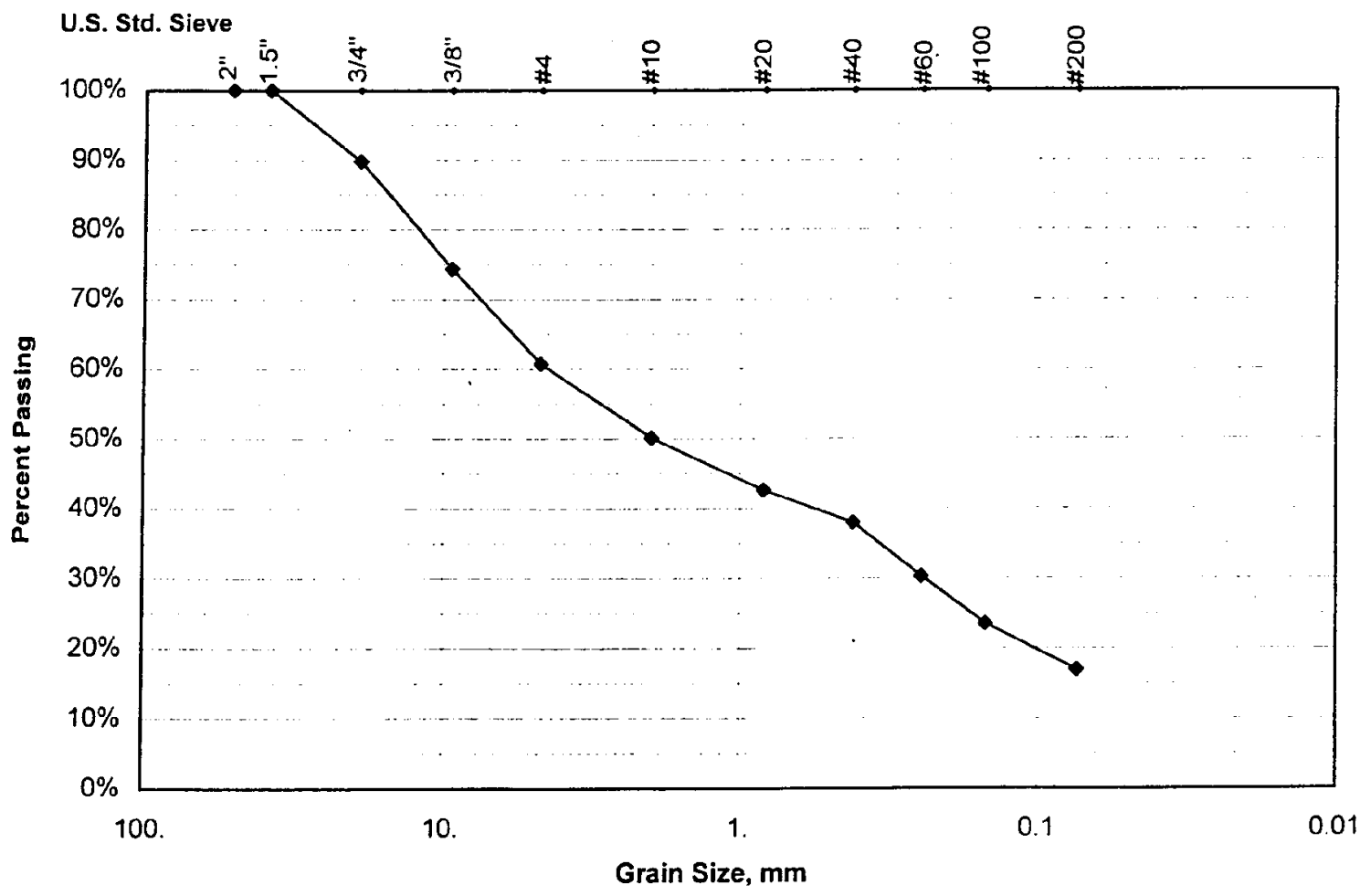

Comments: Silty Sandy Gravel

All data are accuratgly and completely recorded.

Checked By: DCYlectex Date: $9 / 7 / 00$

B.5 


\begin{tabular}{|c|c|c|c|c|c|c|}
\hline & & & $\begin{array}{l}\text { R2M Hilithan } \\
\text { SIEVE ANAI }\end{array}$ & $\begin{array}{l}\text { ord, Inc. } \\
\text { ysIS }\end{array}$ & & \\
\hline WELL NAME & 299-W14-15 & DEPTH & $237.5^{\prime}-240.0^{\prime}$ & SAMPLE\# & W14-15-237.5 & $\overline{\text { WELLID\# }}$ \\
\hline TESTED BY & JMW & CONTACT & Dave Weekes & PHONE & $372-9524$ & $08 / 31 / 2000$ \\
\hline $\begin{array}{l}\text { SAMPLE } \\
W T(g)\end{array}$ & $\begin{array}{l}\text { SIEVE } \\
\text { SIZE IN. }\end{array}$ & $\begin{array}{l}\text { CUMULATIVE } \\
\text { WEIGHT(g) }\end{array}$ & $\begin{array}{l}\% \text { WEIGHT } \\
\text { RETAINED }\end{array}$ & $\begin{array}{c}\% \\
\text { PASSING }\end{array}$ & $\begin{array}{c}\text { Grain Size } \\
(\mathrm{mm})\end{array}$ & COMMENTS \\
\hline 753.80 & $2 "$ & 0.0 & 0.0 & 100.0 & 50.80 & \\
\hline & $1.5^{\prime \prime}$ & 0.0 & 0.0 & 100.0 & 38.10 & \\
\hline & $3 / 4 "$ & 127.8 & 17.0 & 83.0 & 19.05 & \\
\hline & $3 / 8^{\prime \prime}$ & 262.9 & 34.9 & 65.1 & 9.42 & \\
\hline & $\# 4$ & 337.3 & 44.7 & 55.3 & 4.70 & \\
\hline & $\# 10$ & 388.7 & 51.6 & 48.4 & 1.98 & \\
\hline & \#20 & 420.4 & 55.8 & 44.2 & 0.83 & \\
\hline & $\# 40$ & 453.4 & 60.1 & 39.9 & 0.42 & \\
\hline & $\# 60$ & 562.4 & 74.6 & 25.4 & 0.25 & \\
\hline & \#100 & 613.4 & 81.4 & 18.6 & 0.150 & \\
\hline & $\# 200$ & 653.2 & 86.7 & 13.3 & 0.074 & \\
\hline
\end{tabular}

\section{Sieve Analysis Data for Sample W14-15-237.5}

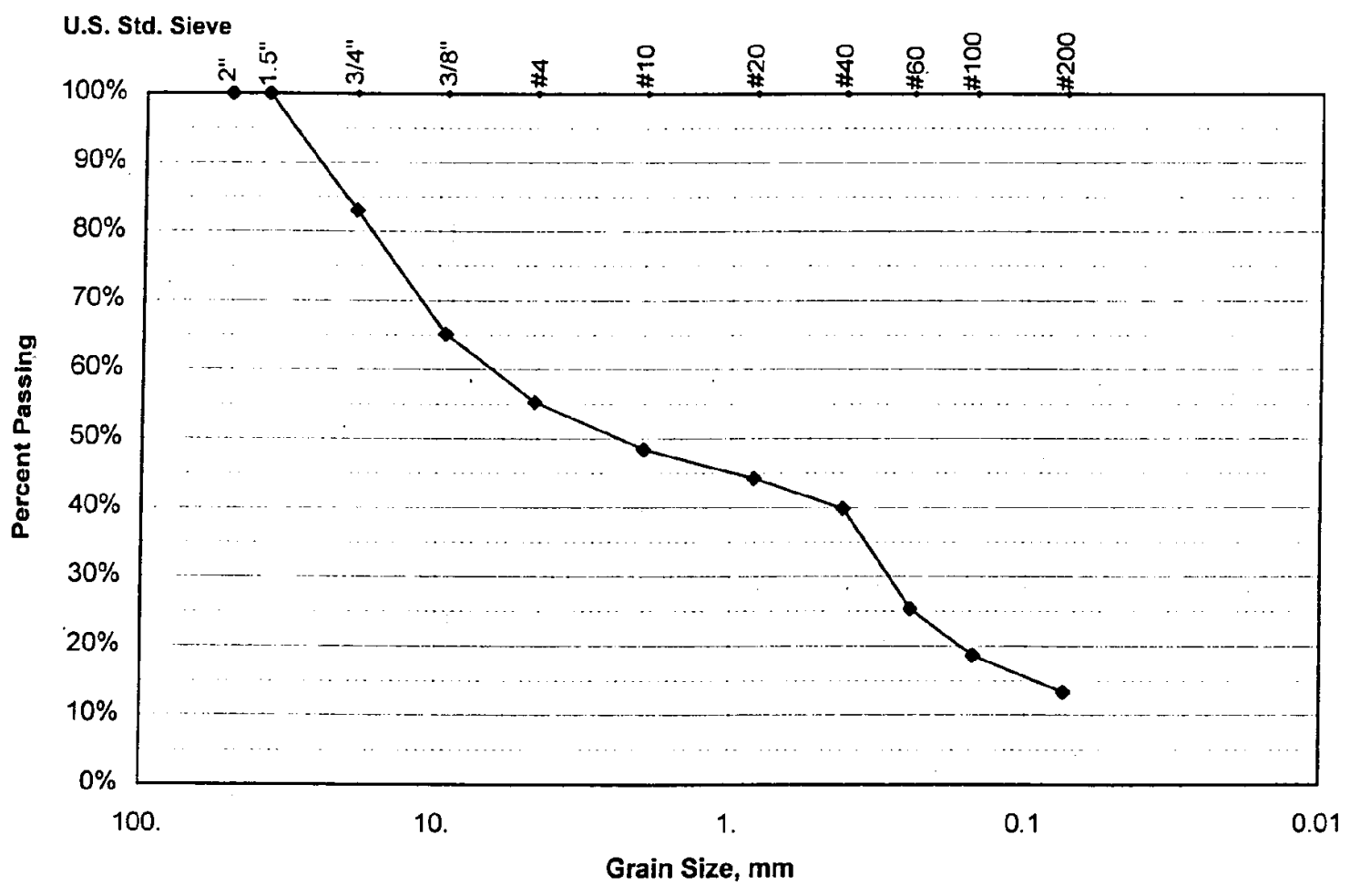

Comments: Silty Sandy Gravel

All data are accurately and completely recorded.

Checked By: Al lecker $\quad$ Date: $9 / 7 / 00$

B.6 


\begin{tabular}{|c|c|c|c|c|c|c|}
\hline \multicolumn{7}{|c|}{ SIEVE ANALYSIS } \\
\hline WELL NAME & $299-W 14-15$ & DEिTH & $252.5^{\prime}-254.5^{\top}$ & SAMPLE\# & $\overline{W 14-15-252.5}$ & $\overline{\text { WELL ID\# }}$ \\
\hline TESTED BY & JMW & CONTACT & Dave Weekes & PHONE & $372-9524$ & DATE $\quad 08 / 31 / 2000$ \\
\hline $\begin{array}{l}\text { SAMPLE } \\
W T(g) \\
\end{array}$ & $\begin{array}{c}\text { SIEVE } \\
\text { SIZE IN. }\end{array}$ & \begin{tabular}{|c} 
CUMULATIVE \\
WEIGHT(g)
\end{tabular} & $\begin{array}{l}\text { \% WEIGHT } \\
\text { RETAINED }\end{array}$ & $\begin{array}{c}\% \\
\text { PASSING }\end{array}$ & $\begin{array}{c}\text { Grain Size } \\
(\mathrm{mm})\end{array}$ & COMMENTS \\
\hline 958.40 & $2^{\prime \prime}$ & 0.0 & 0.0 & 100.0 & 50.80 & \\
\hline & $1.5^{\prime \prime}$ & 0.0 & 0.0 & 100.0 & 38.10 & \\
\hline & $3 / 4^{\prime \prime}$ & 107.7 & 11.2 & 88.8 & 19.05 & \\
\hline & $3 / 8^{\prime \prime}$ & 320.5 & 33.4 & 66.6 & 9.42 & \\
\hline & $\# 4$ & 442.4 & 46.2 & 53.8 & 4.70 & \\
\hline & $\# 10$ & 529.9 & 55.3 & 44.7 & 1.98 & \\
\hline & $\# 20$ & 596.6 & 62.2 & 37.8 & 0.83 & \\
\hline & $\# 40$ & 659.8 & 68.8 & 31.2 & 0.42 & \\
\hline & $\# 60$ & 761.8 & 79.5 & 20.5 & 0.25 & \\
\hline & \#100 & 831.1 & 86.7 & 13.3 & 0.150 & \\
\hline & \#200 & 878.2 & 91.6 & 8.4 & 0.074 & \\
\hline
\end{tabular}

\section{Sieve Analysis Data for Sample W14-15-252.5}

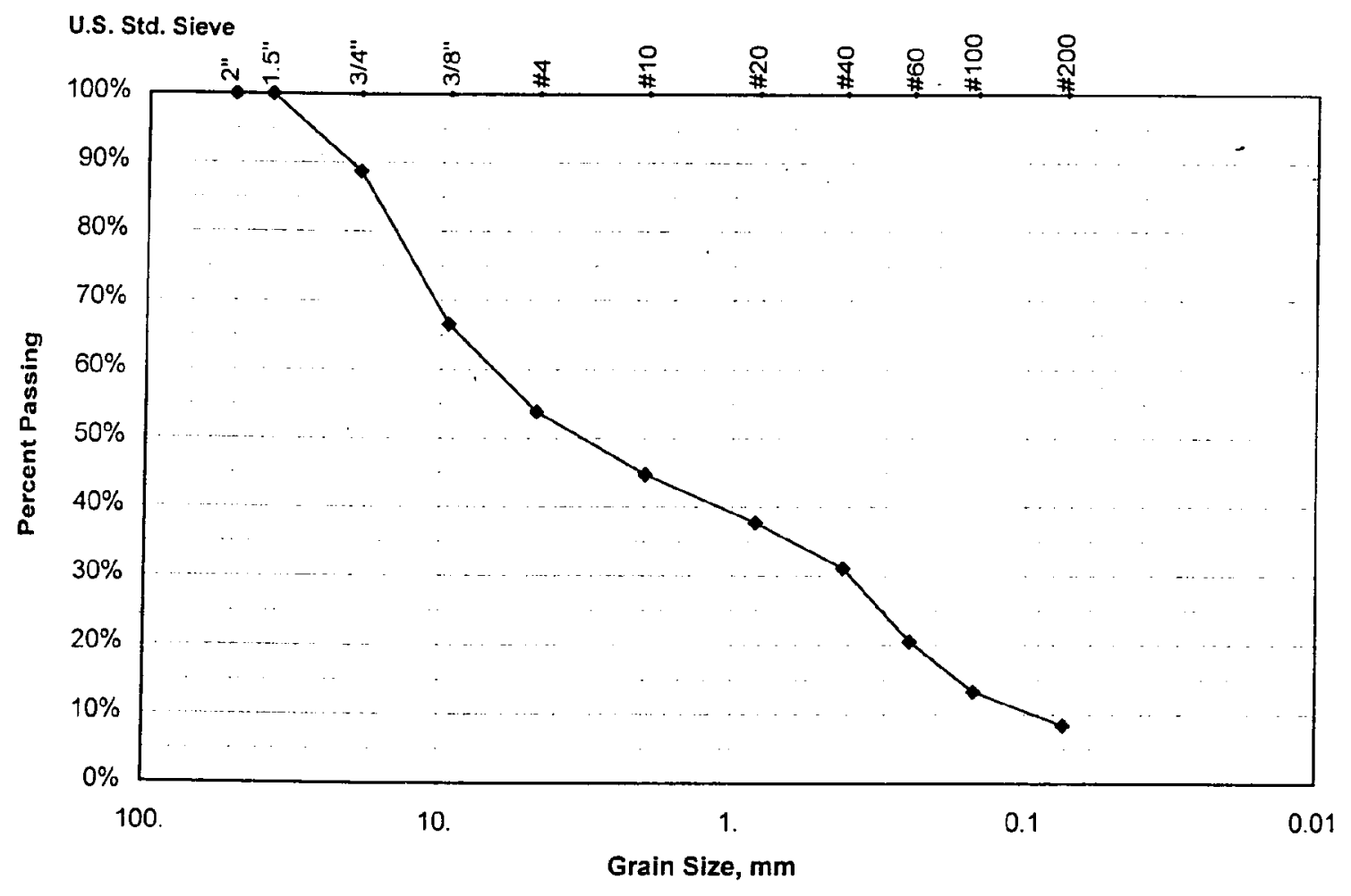

Comments: Sandy Gravel

All data are accurately and completely recorded.

Checked By: Do zee $\quad$ Date: $9 / 7 / 00$

B.7 


\begin{tabular}{|c|c|c|c|c|c|c|}
\hline \multicolumn{7}{|c|}{ CH2h Hill Hanford, Inc. } \\
\hline WELL NAME & 299-W14-16 & DEPTH & $223.2^{\prime}-224.7^{\prime}$ & SAMPLE\# & W14-16-223.2 & WELL ID\# \\
\hline TESTED BY & JMW & CONTACT & Dave Weekes & PHONE & $372-9524$ & DATE $\quad 11 / 21 / 2000$ \\
\hline $\begin{array}{l}\text { SAMPLE } \\
W T(g) \\
\end{array}$ & $\begin{array}{c}\text { SIEVE } \\
\text { SIZE IN. }\end{array}$ & $\begin{array}{c}\text { CUMULATIVE } \\
\text { WEIGHT(g) }\end{array}$ & $\begin{array}{l}\% \text { WEIGHT } \\
\text { RETAINED }\end{array}$ & $\begin{array}{c}\% \\
\text { PASSING }\end{array}$ & $\begin{array}{c}\text { Grain Size } \\
(\mathrm{mm})\end{array}$ & COMMENTS \\
\hline 972.30 & $2^{\prime \prime}$ & 0.0 & 0.0 & 100.0 & 50.80 & \\
\hline & $1.5^{\prime \prime}$ & 0.0 & 0.0 & 100.0 & 38.10 & \\
\hline & $3 / 4^{\prime \prime}$ & 109.7 & 11.3 & 88.7 & 19.05 & \\
\hline & $3 / 8^{\prime \prime}$ & 260.0 & 26.7 & 73.3 & 9.42 & \\
\hline & $\# 4$ & 386.9 & 39.8 & 60.2 & 4.70 & \\
\hline & $\# 10$ & 514.7 & 52.9 & 47.1 & 1.98 & \\
\hline & $\# 20$ & 596.6 & 61.4 & 38.6 & 0.83 & \\
\hline & $\# 40$ & 643.8 & 66.2 & 33.8 & 0.42 & \\
\hline & $\# 60$ & 715.8 & 73.6 & 26.4 & 0.25 & \\
\hline & $\# 100$ & 795.3 & 81.8 & 18.2 & 0.150 & \\
\hline & $\# 200$ & 867.3 & 89.2 & 10.8 & 0.074 & \\
\hline
\end{tabular}

Sieve Analysis Data for Sample W14-16-223.2

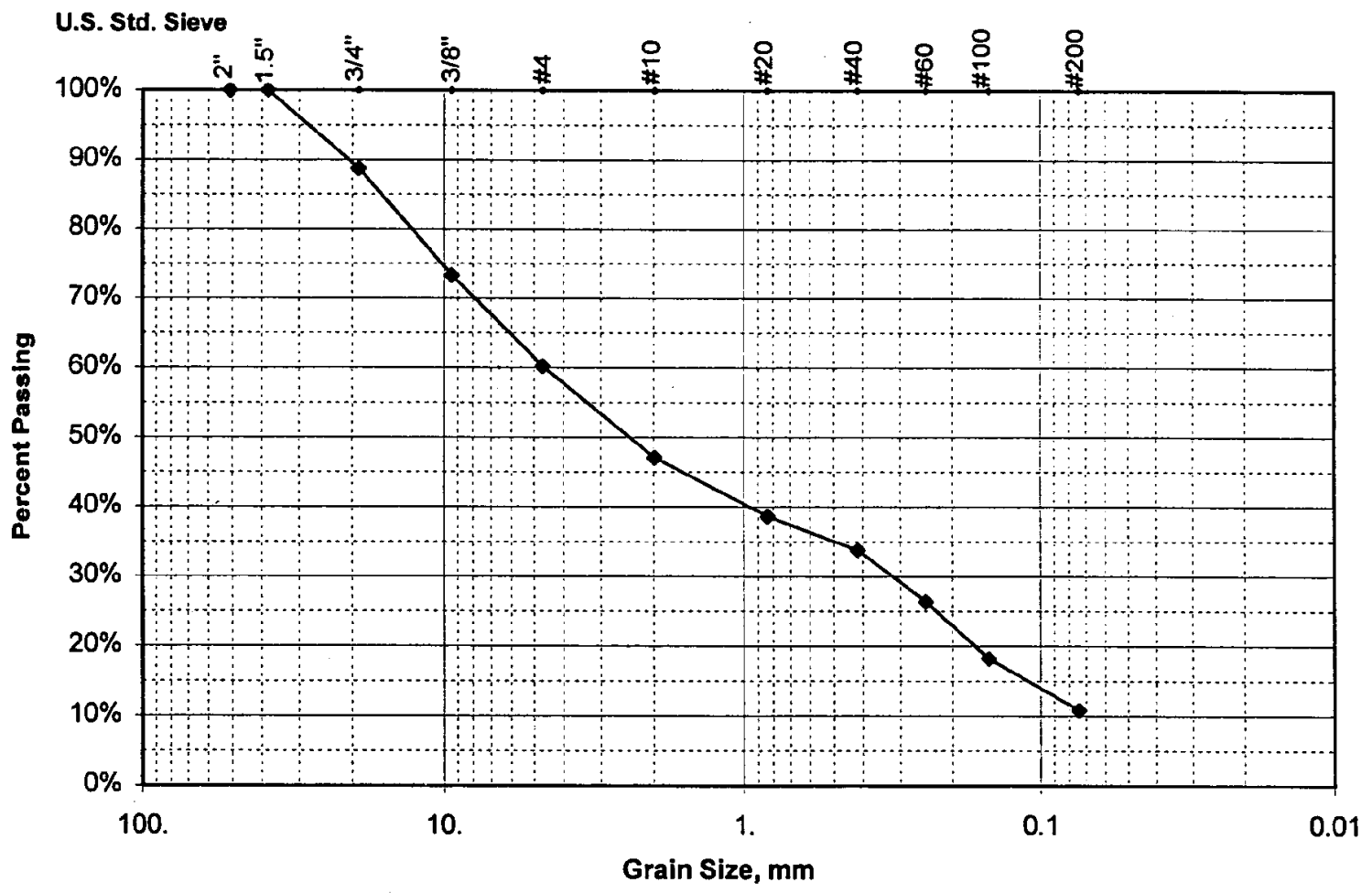

Comments: Silty Sandy Gravel

All data are accurately and completely recorded. Checked By: AY Zleeteck Date: $12 / 27 / 00$ 


\begin{tabular}{|c|c|c|c|c|c|c|}
\hline \multicolumn{7}{|c|}{$\begin{array}{c}\text { CH2M HIITHantord, Inc. } \\
\text { SIEVE ANALYSIS }\end{array}$} \\
\hline WELL NAME & $\overline{299-W 14-16}$ & DEPTH & $241.1^{\prime}-244.0^{\prime}$ & $\overline{\overline{\text { SAMPLE\# }}}$ & $\overline{\text { W14-16-241.1 }}$ & $\overline{\text { WELL ID\# }}$ \\
\hline TESTED BY & JMW & CONTACT & Dave Weekes & PHONE & $372-9524$ & DATE $11 / 21 / 2000$ \\
\hline $\begin{array}{l}\text { SAMPLE } \\
W T(g)\end{array}$ & $\begin{array}{l}\text { SIEVE } \\
\text { SIZE IN. }\end{array}$ & $\begin{array}{l}\text { CUMULATIVE } \\
\text { WEIGHT(g) }\end{array}$ & $\begin{array}{l}\text { \% WEIGHT } \\
\text { RETAINED }\end{array}$ & $\begin{array}{c}\% \\
\text { PASSING }\end{array}$ & $\begin{array}{c}\text { Grain Size } \\
\text { (mm) }\end{array}$ & COMMENTS \\
\hline 978.50 & $2^{11}$ & 0.0 & 0.0 & 100.0 & 50.80 & \\
\hline & $1.5^{11}$ & 193.3 & 19.8 & 80.2 & 38.10 & \\
\hline & $3 / 4^{\prime \prime}$ & 304.6 & 31.1 & 68.9 & 19.05 & \\
\hline & $3 / 8^{11}$ & 476.8 & 48.7 & 51.3 & 9.42 & \\
\hline & $\# 4$ & 572.9 & 58.5 & 41.5 & 4.70 & \\
\hline & $\# 10$ & 651.1 & 66.5 & 33.5 & 1.98 & \\
\hline & $\# 20$ & 699.3 & 71.5 & 28.5 & 0.83 & \\
\hline & $\# 40$ & 729.9 & 74.6 & 25.4 & 0.42 & \\
\hline & $\# 60$ & 821.4 & 83.9 & 16.1 & 0.25 & \\
\hline & $\# 100$ & 880.2 & 90.0 & 10.0 & 0.150 & \\
\hline & $\# 200$ & 910.7 & 93.1 & 6.9 & 0.074 & \\
\hline
\end{tabular}

Sieve Analysis Data for Sample W14-16-241.1

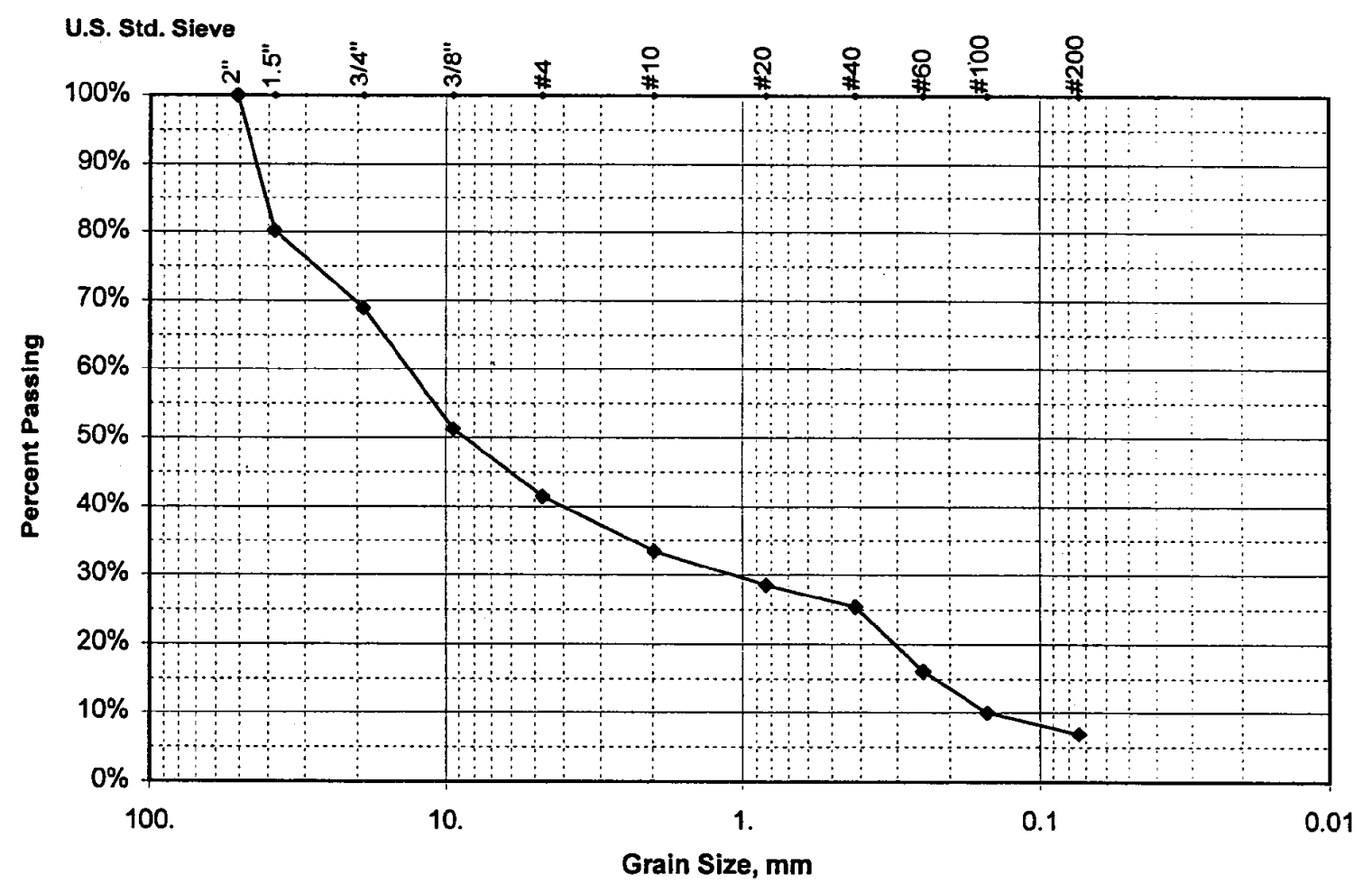

Comments: Sandy Gravel

All data are accurately and completely recorded. Checked By: Ut Clee pax $13 / 27 / 00$

B.9 


\begin{tabular}{|c|c|c|c|c|c|c|}
\hline \multicolumn{7}{|c|}{$\begin{array}{c}\text { CH2IM HIII Hantord, Inc. } \\
\text { SIEVE ANALYSIS }\end{array}$} \\
\hline WELLNAME & 299-W14-16 & DEPTH & $252.0^{\prime}-253.5^{\prime}$ & SAMPLE\# & W14-16-252.0 & \begin{tabular}{|lr} 
WELL ID\# & C3120 \\
DIn In
\end{tabular} \\
\hline TESTED BY & JMW & CONTACT & Dave Weekes & PHONE & 372-9524 & 11/21/2000 \\
\hline \begin{tabular}{|l|} 
SAMPLE \\
WT (g) \\
\end{tabular} & $\begin{array}{l}\text { SIEVE } \\
\text { SIZE IN. }\end{array}$ & $\begin{array}{l}\text { CUMULATIVE } \\
\text { WEIGHT(g) } \\
\end{array}$ & $\begin{array}{l}\% \text { WEIGHT } \\
\text { RETAINED }\end{array}$ & $\begin{array}{c}\% \\
\text { PASSING }\end{array}$ & $\begin{array}{c}\text { Grain Size } \\
(\mathrm{mm})\end{array}$ & COMMENTS \\
\hline 986.60 & $2 "$ & 0.0 & 0.0 & 100.0 & 50.80 & \\
\hline & $1.5^{\prime \prime}$ & 0.0 & 0.0 & 100.0 & 38.10 & \\
\hline & $3 / 4^{\prime \prime}$ & 182.4 & 18.5 & 81.5 & 19.05 & \\
\hline & $3 / 8^{\prime \prime}$ & 387.7 & 39.3 & 60.7 & 9.42 & \\
\hline & $\# 4$ & 494.5 & 50.1 & 49.9 & 4.70 & \\
\hline & $\# 10$ & 577.2 & 58.5 & 41.5 & 1.98 & \\
\hline & $\# 20$ & 623.2 & 63.2 & 36.8 & 0.83 & \\
\hline & $\# 40$ & 657.1 & 66.6 & 33.4 & 0.42 & \\
\hline & $\# 60$ & 788.6 & 79.9 & 20.1 & 0.25 & \\
\hline & $\# 100$ & 868.1 & 88.0 & 12.0 & 0.150 & \\
\hline & $\# 200$ & 904.0 & 91.6 & 8.4 & 0.074 & \\
\hline
\end{tabular}

Sieve Analysis Data for Sample W14-16-252.0

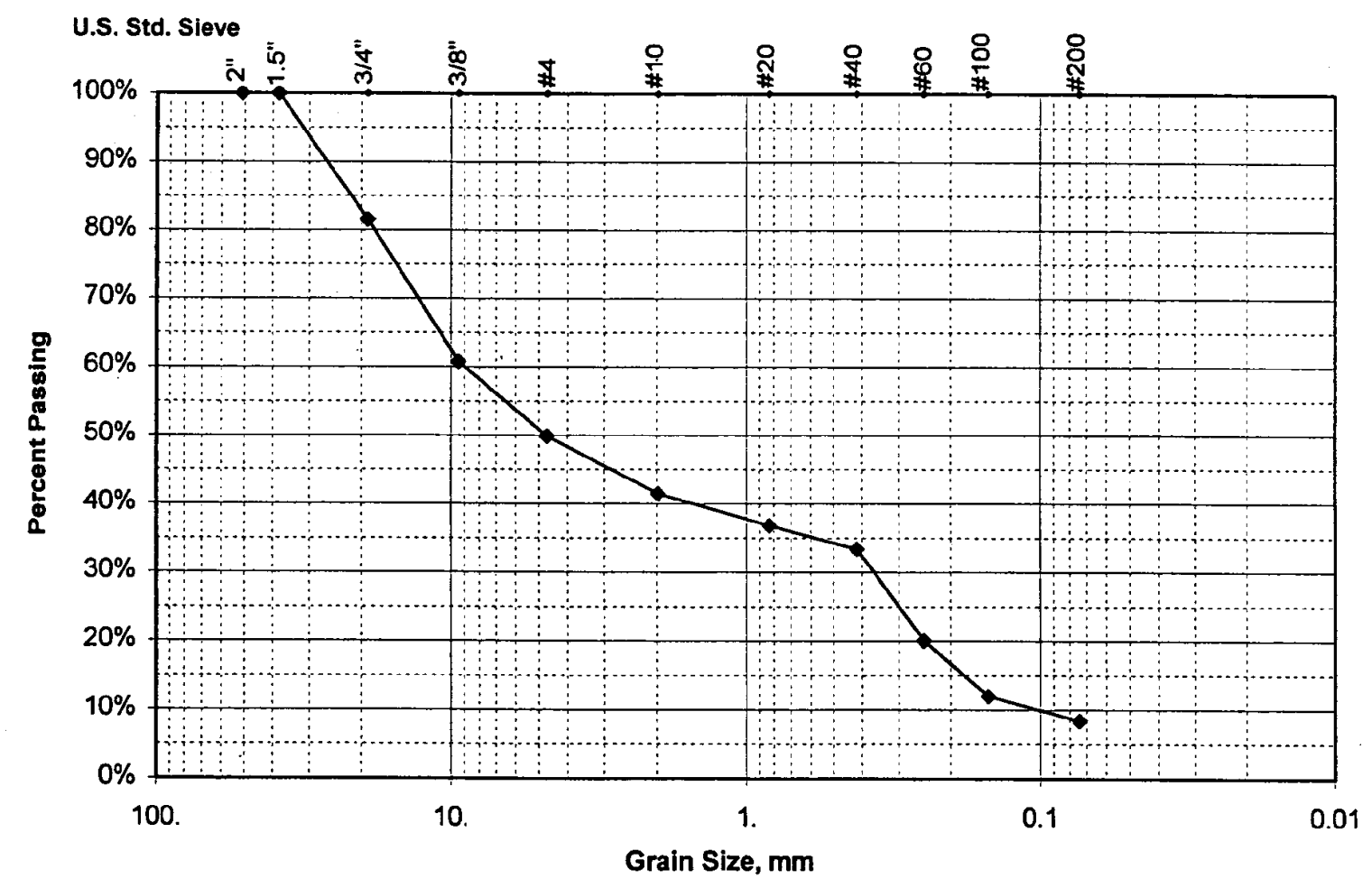

Comments: Sandy Gravel

All data are accuratesy and completely recorded. Checked By: DCOzectaes Date: $12 / 27 / 00$

B. 10 
CH2M Hill Hantord, Inc.

SIEVE ANALYSIS

\begin{tabular}{|c|c|c|c|c|c|c|}
\hline WELL NAME & 299-W14-17 & DEPTH & $228.0^{\prime}-228.75^{\top}$ & SAMPLE\# & \multirow{2}{*}{\multicolumn{2}{|c|}{\begin{tabular}{|c||rr|} 
W14-17-228.0 & WELL ID\# & C3121 \\
$372-9524$ & DATE & $10 / 18 / 2000$ \\
\end{tabular}}} \\
\hline TESTED BY & JMW & CONTACT & Dave Weekes & PHONE & & \\
\hline $\begin{array}{l}\text { SAMPLE } \\
W T(g)\end{array}$ & $\begin{array}{l}\text { SIEVE } \\
\text { SIZE IN. }\end{array}$ & $\begin{array}{l}\text { CUMULATIVE } \\
\text { WEIGHT(g) }\end{array}$ & $\begin{array}{l}\text { \% WEIGHT } \\
\text { RETAINED }\end{array}$ & $\begin{array}{c}\% \\
\text { PASSING }\end{array}$ & $\begin{array}{l}\text { Grain Size } \\
(\mathrm{mm})\end{array}$ & COMMENTS \\
\hline \multirow[t]{11}{*}{966.40} & $2 "$ & 0.0 & 0.0 & 100.0 & 50.80 & \\
\hline & $1.5^{\prime \prime}$ & 0.0 & 0.0 & 100.0 & 38.10 & \\
\hline & $3 / 4^{\prime \prime}$ & 238.4 & 24.7 & 75.3 & 19.05 & \\
\hline & $3 / 8^{\prime \prime}$ & 416.4 & 43.1 & 56.9 & 9.42 & \\
\hline & $\# 4$ & 537.9 & 55.7 & 44.3 & 4.70 & \\
\hline & $\# 10$ & 615.0 & 63.6 & 36.4 & 1.98 & \\
\hline & $\# 20$ & 660.0 & 68.3 & 31.7 & 0.83 & \\
\hline & $\# 40$ & 689.4 & 71.3 & 28.7 & 0.42 & \\
\hline & $\# 60$ & 782.5 & 81.0 & 19.0 & 0.25 & \\
\hline & $\# 100$ & 847.7 & 87.7 & 12.3 & 0.150 & \\
\hline & $\# 200$ & 884.7 & 91.5 & 8.5 & 0.074 & \\
\hline
\end{tabular}

Sieve Analysis Data for Sample W14-17-228.0

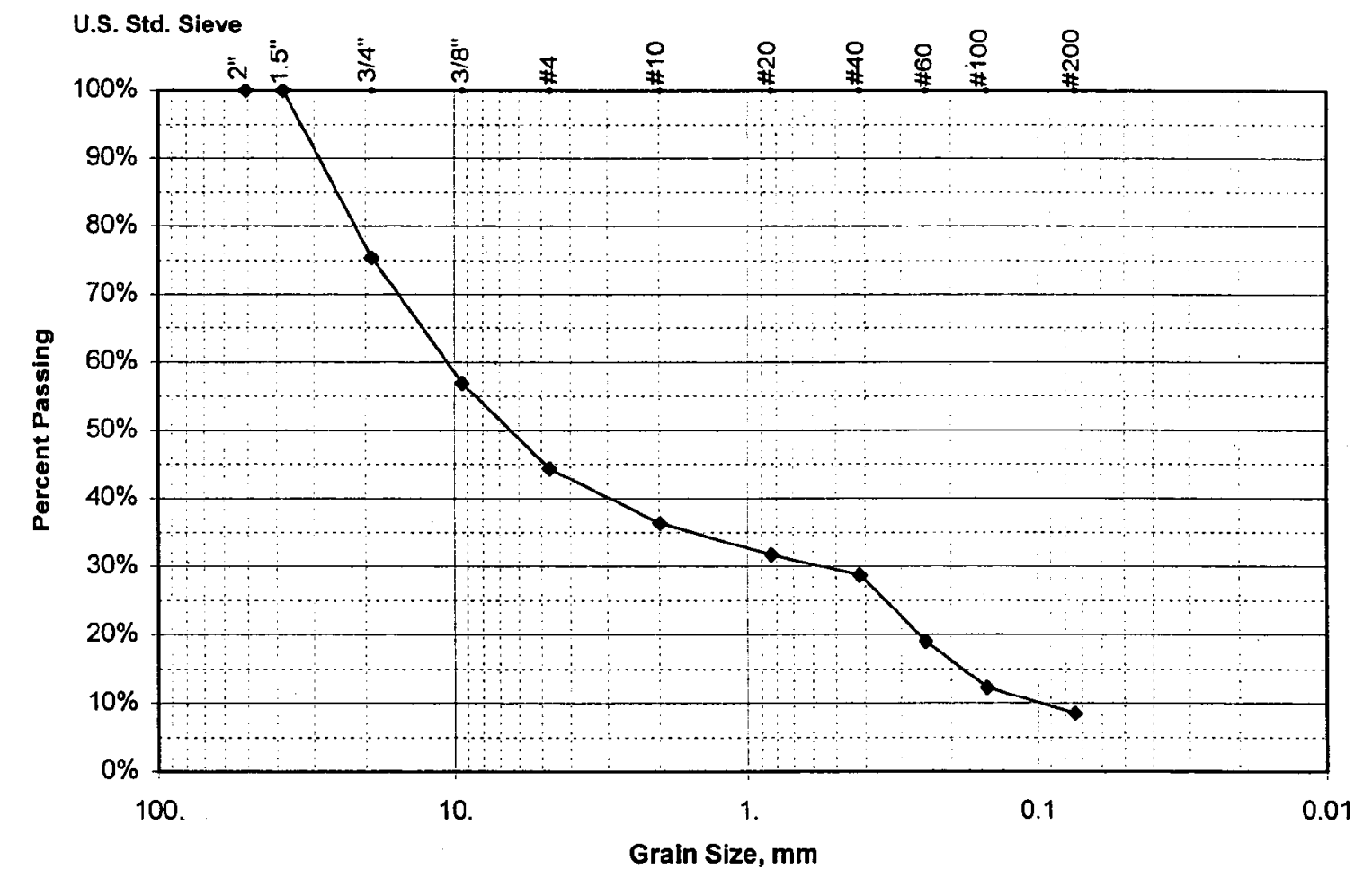

Comments: Sandy Gravel

All data are accuratey and completely recorded.

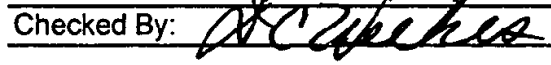
Date: $11 / 14 / 00$

B.11 


\begin{tabular}{|c|c|c|c|c|c|c|}
\hline \multicolumn{7}{|c|}{$\begin{array}{c}\text { CH2IV Hill Hanford, Inc. } \\
\text { SIEVE ANALYSIS }\end{array}$} \\
\hline WELL NAME & 299-W14-17 & |DEPTH & $244.9^{\prime}-246.4^{\prime}$ & SAMPLE\# & W14-17-244.9 & WELL ID\# \\
\hline TESTED BY & JMW & CONTACT & Dave Weekes & PHONE & $372-9524$ & $10 / 18 / 2000$ \\
\hline $\begin{array}{l}\text { SAMPLE } \\
\text { WT }(g)\end{array}$ & $\begin{array}{c}\text { SIEVE } \\
\text { SIZE IN. }\end{array}$ & $\begin{array}{l}\text { CUMULATIVE } \\
\text { WEIGHT(g) }\end{array}$ & $\begin{array}{l}\% \text { WEIGHT } \\
\text { RETAINED }\end{array}$ & $\begin{array}{c}\% \\
\text { PASSING }\end{array}$ & $\begin{array}{c}\text { Grain Size } \\
(\mathrm{mm})\end{array}$ & COMMENTS \\
\hline 931.20 & $2 "$ & 0.0 & 0.0 & 100.0 & 50.80 & \\
\hline & $1.5^{\prime \prime}$ & 0.0 & 0.0 & 100.0 & 38.10 & \\
\hline & $3 / 4^{\prime \prime}$ & 138.5 & 14.9 & 85.1 & 19.05 & \\
\hline & $3 / 8^{\prime \prime}$ & 373.5 & 40.1 & 59.9 & 9.42 & \\
\hline & $\# 4$ & 503.2 & 54.0 & 46.0 & 4.70 & \\
\hline & $\# 10$ & 598.3 & 64.3 & 35.7 & 1.98 & \\
\hline & $\# 20$ & 648.4 & 69.6 & 30.4 & 0.83 & \\
\hline & $\# 40$ & 675.6 & 72.6 & 27.4 & 0.42 & \\
\hline & $\# 60$ & 747.2 & 80.2 & 19.8 & 0.25 & \\
\hline & $\# 100$ & 806.0 & $\overline{86.6}$ & 13.4 & 0.150 & \\
\hline & $\# 200$ & 841.7 & 90.4 & 9.6 & 0.074 & \\
\hline
\end{tabular}

\section{Sieve Analysis Data for Sample W14-17-244.9}

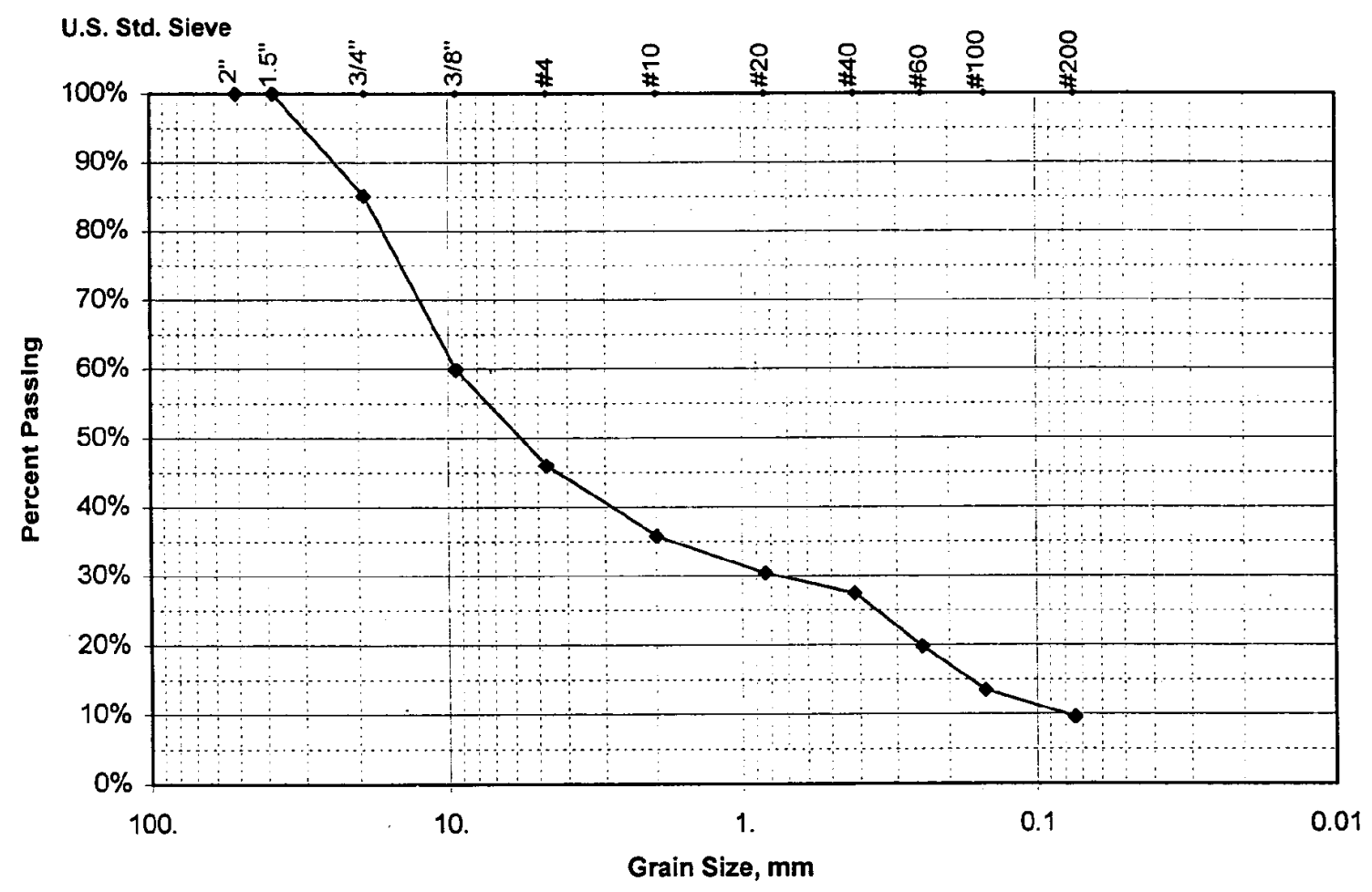

Comments: Sandy Gravel

All data are accurate," and completgly recorded Checked By: DVC Uleeten Date: $11 / 14 / 00$

B. 12 
CHzM Hill Hantord, Inc.

SIEVE ANALYSIS

\begin{tabular}{|c|c|c|c|c|c|c|}
\hline WELL NAME & 299-W14-17 & DEPTH & $255.4^{\prime}-257.9^{\prime}$ & SAMPLE\# & $\overline{~ W 14-17-255.4}$ & WELLID\# \\
\hline TTESTED BY & JMW & CONTACT & Dave Weekes & PHONE & $\overline{372-9524}$ & $10 / 18 / 2000$ \\
\hline $\begin{array}{l}\text { SAMPLE } \\
W T(g)\end{array}$ & $\begin{array}{l}\text { SIEVE } \\
\text { SIZE IN. }\end{array}$ & $\begin{array}{l}\text { CUMULATIVE } \\
\text { WEIGHT(g) }\end{array}$ & $\begin{array}{l}\text { \% WEIGHT } \\
\text { RETAINED }\end{array}$ & $\begin{array}{c}\% \\
\text { PASSING }\end{array}$ & $\begin{array}{c}\text { Grain Size } \\
(\mathrm{mm})\end{array}$ & COMMENTS \\
\hline \multirow[t]{11}{*}{970.40} & $2^{\prime \prime}$ & 0.0 & 0.0 & 100.0 & 50.80 & \\
\hline & $1.5^{\prime \prime}$ & 0.0 & 0.0 & 100.0 & 38.10 & \\
\hline & $3 / 4^{\prime \prime}$ & 143.6 & 14.8 & 85.2 & 19.05 & \\
\hline & $3 / 8^{\prime \prime}$ & 355.0 & 36.6 & 63.4 & 9.42 & \\
\hline & $\# 4$ & 466.1 & 48.0 & 52.0 & 4.70 & \\
\hline & $\# 10$ & 544.6 & 56.1 & 43.9 & 1.98 & \\
\hline & $\# 20$ & 595.0 & 61.3 & 38.7 & 0.83 & \\
\hline & $\# 40$ & 642.1 & 66.2 & 33.8 & 0.42 & \\
\hline & $\# 60$ & 757.6 & 78.1 & 21.9 & 0.25 & \\
\hline & $\# 100$ & 813.5 & 83.8 & 16.2 & 0.150 & \\
\hline & $\# 200$ & 858.2 & 88.4 & 11.6 & 0.074 & \\
\hline
\end{tabular}

Sieve Analysis Data for Sample W14-17-255.4

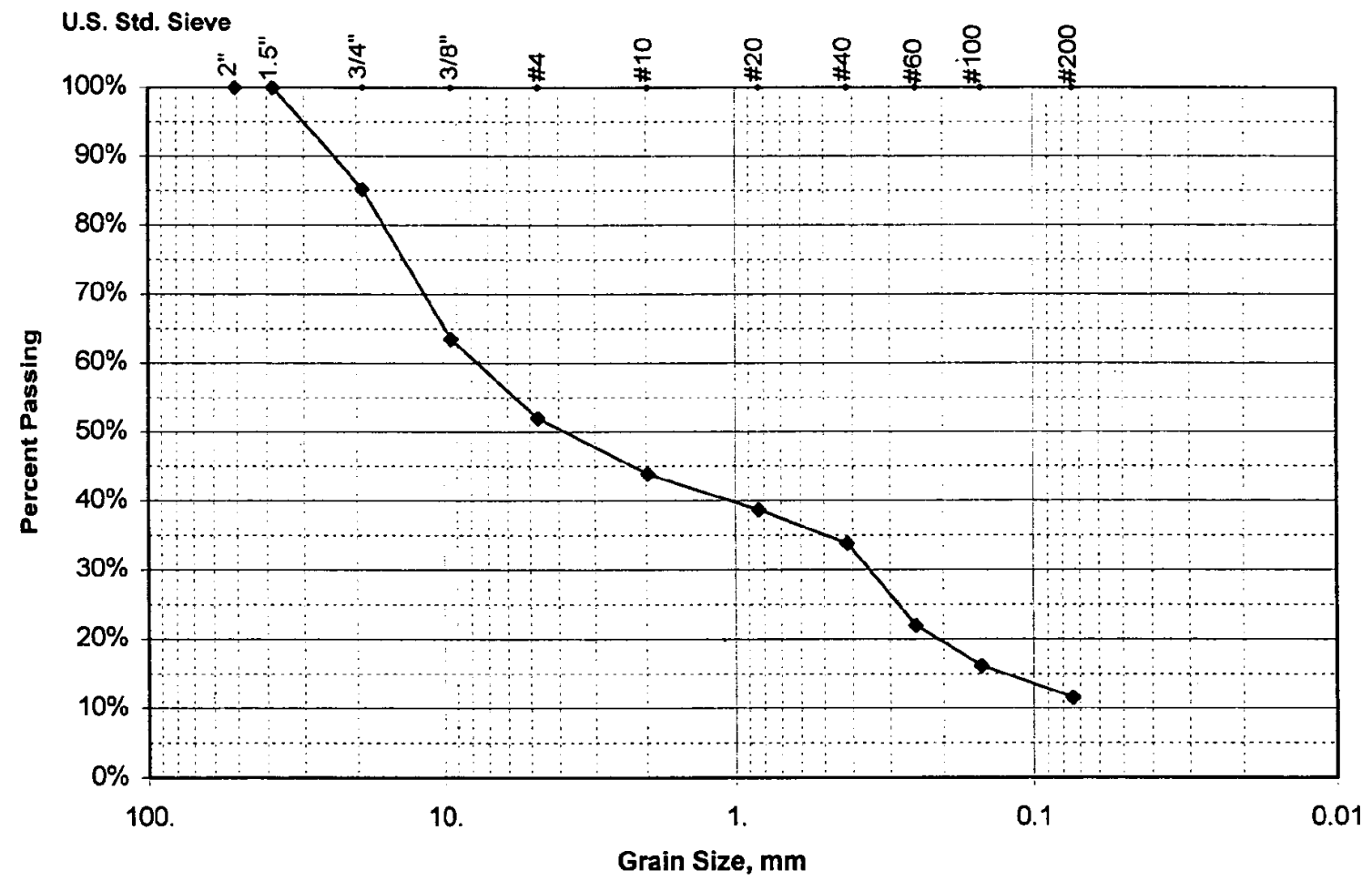

Comments: Silty Sandy Gravel

All data are accuratety and completgly recorded.

Checked By: De Ifeeted $11 / 14 / 00$

B.13 


\begin{tabular}{|c|c|c|c|c|c|c|}
\hline \multicolumn{7}{|c|}{ CH2I Hill Hanford, Inc. } \\
\hline WELL NAME & 299-W15-763 & DEPTH & $217.0^{\prime}-219.0^{\prime}$ & SAMPLE\# & W15-763-217 & WELL ID\# \\
\hline TESTED BY & J.M.Wimett & CONTACT & Dave Weekes & PHONE & $372-9130$ & DATE $\quad 01 / 11 / 2001$ \\
\hline \begin{tabular}{|l} 
SAMPLE \\
WT $(g)$ \\
\end{tabular} & $\begin{array}{c}\text { SIEVE } \\
\text { SIZE IN. }\end{array}$ & $\begin{array}{l}\text { CUMULATIVE } \\
\text { WEIGHT(g) }\end{array}$ & $\begin{array}{l}\% \text { WEIGHT } \\
\text { RETAINED }\end{array}$ & $\begin{array}{c}\% \\
\text { PASSING } \\
\end{array}$ & $\begin{array}{c}\text { Grain Size } \\
(\mathrm{mm})\end{array}$ & COMMENTS \\
\hline 982.20 & $2^{\prime \prime}$ & 0.0 & 0.0 & 100.0 & 50.80 & \\
\hline & $1.5^{\prime \prime}$ & 0.0 & 0.0 & 100.0 & 38.10 & \\
\hline & $3 / 4^{\prime \prime}$ & 189.1 & 19.3 & 80.7 & 19.05 & \\
\hline & $3 / 8^{\prime \prime}$ & 324.2 & 33.0 & 67.0 & 9.42 & \\
\hline & $\# 4$ & 444.8 & 45.3 & 54.7 & 4.70 & \\
\hline & $\# 10$ & 577.6 & 58.8 & 41.2 & 1.98 & \\
\hline & \#20 & 692.4 & 70.5 & 29.5 & 0.83 & \\
\hline & $\# 40$ & 761.8 & 77.6 & 22.4 & 0.42 & \\
\hline & $\# 60$ & 815.7 & 83.0 & 17.0 & 0.25 & \\
\hline & \#100 & 858.7 & 87.4 & 12.6 & 0.150 & \\
\hline & $\# 200$ & 899.9 & 91.6 & 8.4 & 0.074 & . \\
\hline
\end{tabular}

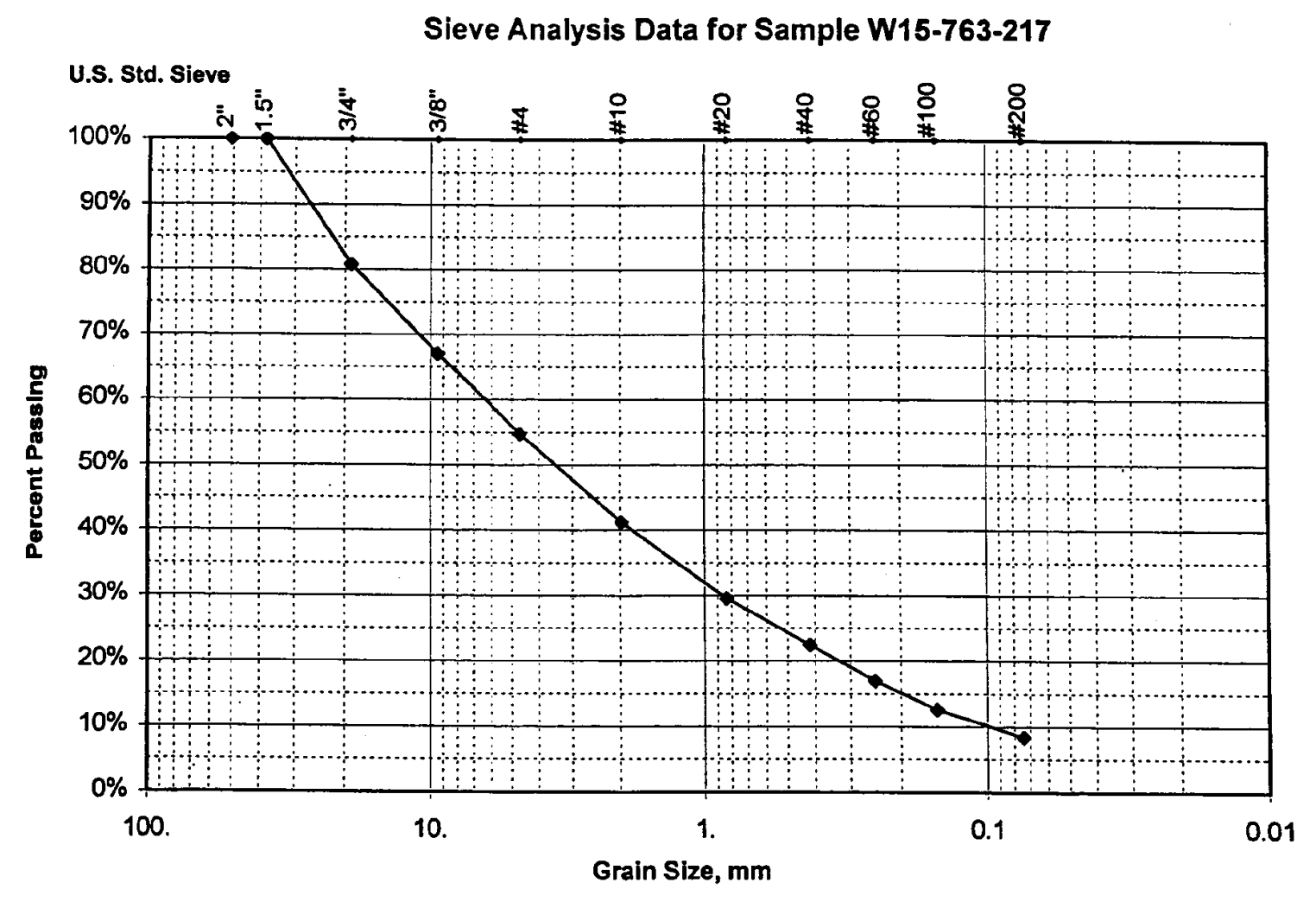

Comments: Sandy Gravel

\begin{tabular}{ll}
\hline Alldata are accurate $y$ and completely recorded. & \\
Checked By: & Date: $3 / 14 \% 0 \%$
\end{tabular}

B.14 


\begin{tabular}{|c|c|c|c|c|c|c|}
\hline \multicolumn{7}{|c|}{$\begin{array}{l}\text { CH2IM HIII Haniord, Inc. } \\
\text { SIEVE ANALYSIS }\end{array}$} \\
\hline \multirow{2}{*}{\begin{tabular}{|l} 
WELL NAME \\
TESTED BY \\
\end{tabular}} & \multicolumn{2}{|c|}{ 299-W15-763 DEPTH } & $232.0^{\circ}-234.0^{\prime}$ & SAMPLE\# & W15-763-232 & \multirow{2}{*}{\begin{tabular}{|lr} 
WELL ID\# & C3339 \\
DATE & $01 / 11 / 2001$ \\
\end{tabular}} \\
\hline & J.M.Wimett & CONTACT & Dave Weekes & PHONE & $372-9130$ & \\
\hline $\begin{array}{l}\text { SAMPLE } \\
\text { WT }(g) \\
\end{array}$ & $\begin{array}{l}\text { SIEVE } \\
\text { SIZE IN. }\end{array}$ & $\begin{array}{l}\text { CUMULATIVE } \\
\text { WEIGHT(g) }\end{array}$ & $\begin{array}{l}\text { \% WEIGHT } \\
\text { RETAINED } \\
\end{array}$ & $\begin{array}{c}\% \\
\text { PASSING }\end{array}$ & $\begin{array}{c}\text { Grain Size } \\
(\mathrm{mm})\end{array}$ & COMMENTS \\
\hline 952.30 & $2 "$ & 0.0 & 0.0 & 100.0 & 50.80 & \\
\hline & $1.5^{\prime \prime}$ & 0.0 & 0.0 & 100.0 & 38.10 & \\
\hline & $3 / 4^{\prime \prime}$ & 57.8 & 6.1 & 93.9 & 19.05 & \\
\hline & $3 / 8^{\prime \prime}$ & 208.8 & 21.9 & 78.1 & 9.42 & \\
\hline & $\# 4$ & 368.0 & 38.6 & 61.4 & 4.70 & \\
\hline & $\# 10$ & 510.2 & 53.6 & 46.4 & 1.98 & \\
\hline & $\# 20$ & 602.3 & 63.2 & 36.8 & 0.83 & \\
\hline & $\# 40$ & 659.1 & 69.2 & 30.8 & 0.42 & \\
\hline & $\# 60$ & 735.6 & 77.2 & 22.8 & 0.25 & \\
\hline & $\# 100$ & 789.7 & 82.9 & 17.1 & 0.150 & \\
\hline & $\# 200$ & 842.1 & 88.4 & 11.6 & 0.074 & \\
\hline
\end{tabular}

Sieve Analysis Data for Sample W15-763-232

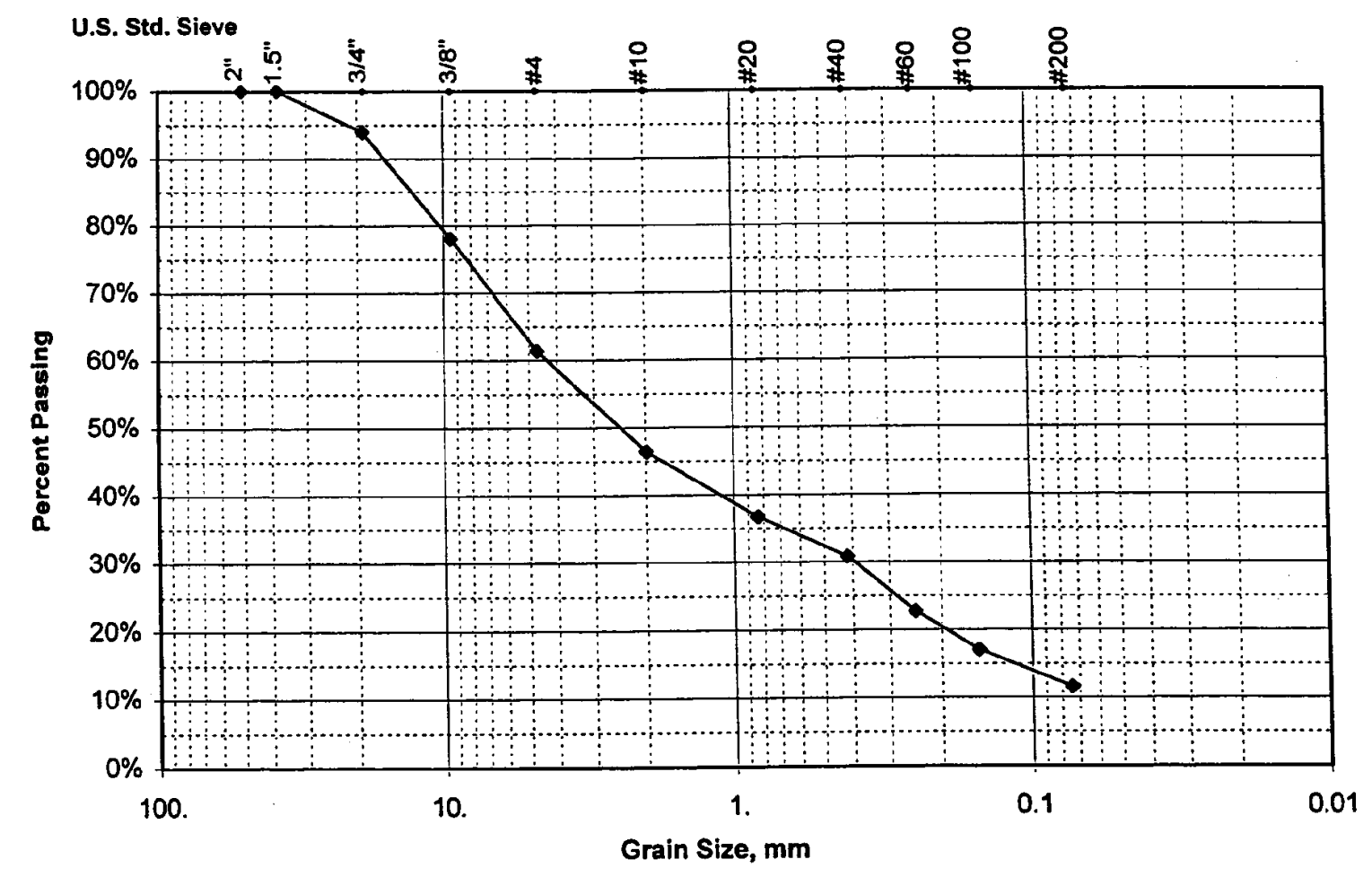

Comments: Silty Sandy Gravel

All data are accuratel and completely recorded.

Checked By: Atelleeted

Date: $3 / 14 / 01$

B.15 


\begin{tabular}{|c|c|c|c|c|c|c|}
\hline \multicolumn{7}{|c|}{ CH2In Hill Hanford, Inc. } \\
\hline WELL NAME & 299-W15-763 & DEPTH & $245.0^{\prime}-247.0^{\prime}$ & SAMPLE\# & W15-763-245 & WELL ID\# \\
\hline TESTED BY & J.M.Wimett & CONTACT & Dave Weekes & PHONE & $372-9130$ & $01 / 11 / 2001$ \\
\hline $\begin{array}{l}\text { SAMPLE } \\
W T(g)\end{array}$ & $\begin{array}{c}\text { SIEVE } \\
\text { SIZE IN. }\end{array}$ & $\begin{array}{l}\text { CUMULATIVE } \\
\text { WEIGHT(g) }\end{array}$ & $\begin{array}{l}\text { \% WEIGHT } \\
\text { RETAINED }\end{array}$ & $\begin{array}{c}\% \\
\text { PASSING }\end{array}$ & $\begin{array}{c}\begin{array}{c}\text { Grain Size } \\
(\mathrm{mm})\end{array} \\
\end{array}$ & COMMENTS \\
\hline 969.90 & $2^{\prime \prime}$ & 0.0 & 0.0 & 100.0 & 50.80 & \\
\hline & $1.5^{\prime \prime}$ & 0.0 & 0.0 & 100.0 & 38.10 & \\
\hline & $3 / 4^{\prime \prime}$ & 97.4 & 10.0 & 90.0 & 19.05 & \\
\hline & $3 / 8^{\prime \prime}$ & 319.4 & 32.9 & 67.1 & 9.42 & \\
\hline & $\# 4$ & 442.2 & 45.6 & 54.4 & 4.70 & \\
\hline & $\# 10$ & 538.4 & 55.5 & 44.5 & 1.98 & \\
\hline & $\# 20$ & 630.3 & 65.0 & 35.0 & 0.83 & \\
\hline & $\# 40$ & 709.9 & 73.2 & 26.8 & 0.42 & \\
\hline & $\# 60$ & 803.3 & 82.8 & 17.2 & 0.25 & \\
\hline & $\# 100$ & 850.3 & 87.7 & 12.3 & 0.150 & \\
\hline & $\# 200$ & 891.7 & 91.9 & 8.1 & 0.074 & \\
\hline
\end{tabular}

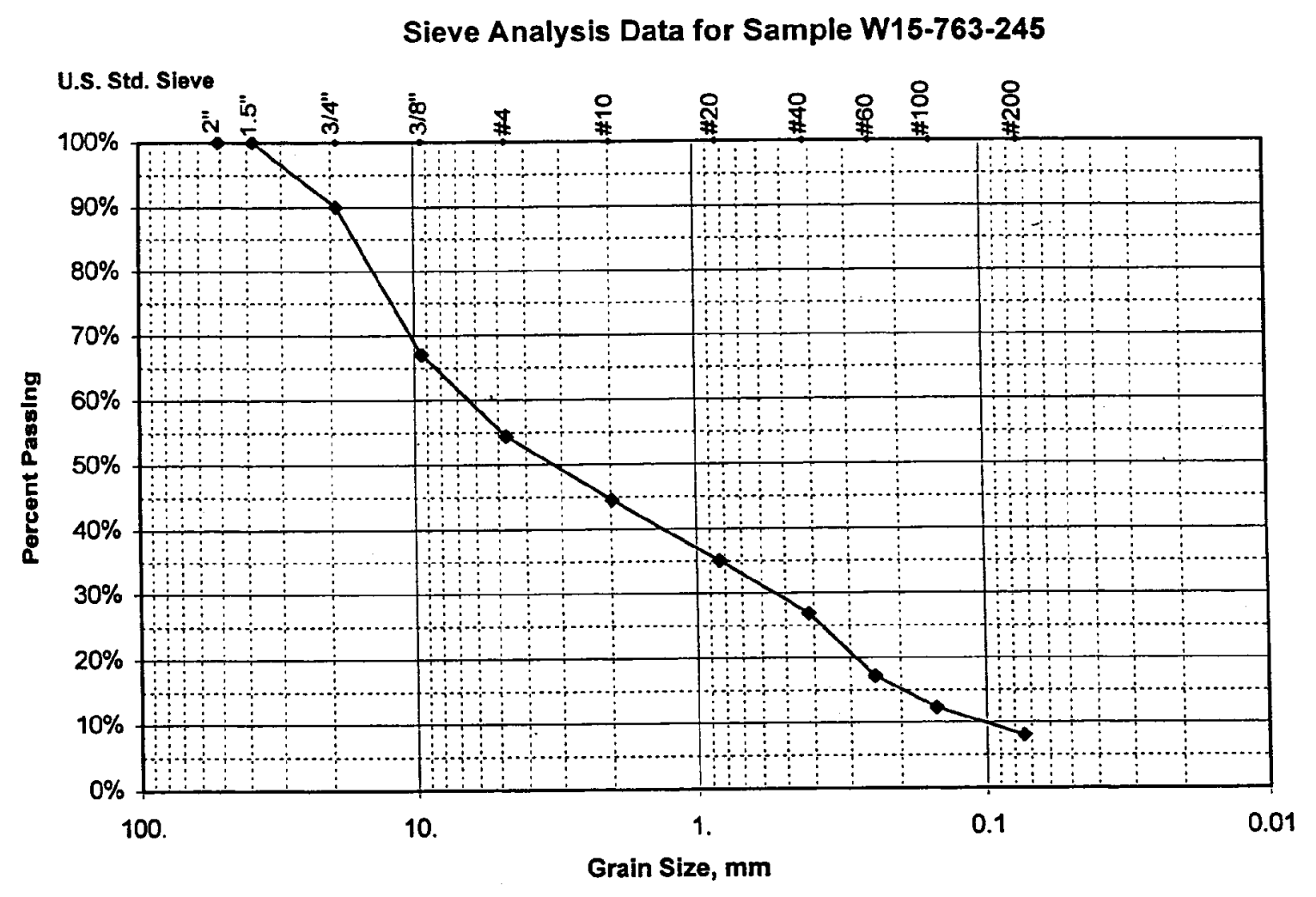

Comments: Sandy Gravel

All data are accurat ty and completely recorded.

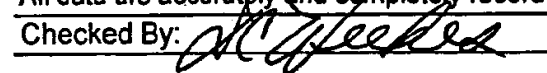
Date:

B. 16 
Appendix C

Geophysical Logs 
This appendix contains the borehole geophysical logs obtained from boreholes 299-W10-27, 299-W14-16, and 299-W14-17. The logs were run and analyzed by Duratek, Waste Management Federal Services Northwest, Inc. Included with the logs are Log Header Sheets and Log Analysis Summary Reports. 


\section{RLS Spectral Gamma Ray Borehole Survey \\ Duratek Federal Services}

\section{Log Header}

Project: $\quad$ RCRA Drilling

Well: 299-W10-27

\section{Log Type: $\quad$ HPGe Spectral Gamma Ray}

Borehole Information

\begin{tabular}{|c|c|c|c|}
\hline Well \# C3125 & Water Depth & $187.5^{*}$ & Total Depth $268.5 \mathrm{ft}$ \\
\hline Elevation Reference $\mathrm{n} / \mathrm{a}$ & Elevation & $\mathrm{n} / \mathrm{a}$ & \\
\hline Depth Reference Ground Surface & Casing Stickup & 3.58 & \\
\hline Casing Diameter 7.625 ID in & Depth Interval & 0 to $264 \mathrm{ft}$ & Thickness \\
\hline Casing Diameter 11.75 ID in & Depth Interval & 0 to $56 \quad \mathrm{ft}$ & Thickness 0.5 in \\
\hline
\end{tabular}

Water depth determined from Moisture Log

\section{Logging Information}

Log Type:

Company

Date/Archive File Name

Logging Engineers

Instrument Series

Logging Unit

Depth Interval

Instrument Calibration Date

Calibration Report
HPGe Spectral Gamma Ray

Duratek Federal Services

March 15, 2001 2HW10027

D. Hollingsworth

RLSG07000S01.0

RLS-1

0 to $160 \mathrm{ft} \quad$ Prefix A713

135 to $260 \mathrm{ft}$. A714

Oct 6, 2000

WHC-SD-EN-TI-292, Rev 0.

Analysis Information

$\begin{array}{ll}\text { Company } & \text { Three Rivers Scientific } \\ \text { Analyst } & \text { Russ Randall } \\ \text { Date } & \text { March 26, 2001 }\end{array}$

Notes No man-made contamination was detected. Many depth intervals have the natural uranium levels below detection threshold. The water level from 187.5 to 260 also reduces the gross gamma and raises detection thresholds. 


\section{Spectral Gamma Ray Log Analysis \& Summary Waste Management Federal Services}

$\begin{array}{ll}\text { Project: } & \text { RCRA Drilling } \\ \text { Log Type: } & \text { HPGe Spectral Gamma Ray }\end{array}$
Well:

299-W10-27

Log Date: $\quad$ March 15, 2001

\section{General Notes:}

Total gamma is a response to geologic concentrations of natural radionuclides. A change in sensitivity of gross gamma to geologic concentrations of natural radionuclides occurs at both the dual casing change at 56 feet and the water level at 187.5 feet.

Log data collected with a depth reference of ground surface.

System Performance Verify: The pre- and post-log verification passed performance standards; a $-0.02 \%$ change was observed in the gross, (based upon borehole survey data sheet). The FWHM of the $583 \mathrm{keV}$ photo peak was also within specifications for pre- and post-log verification.

Repeat Interval: Based on the repeat interval, the logging system performed as per specifications.

Environmental Corrections: All radionuclide concentrations have been corrected for casing attenuation (entire well). Water correction was applied to depths deeper than 187.5 feet. The information on the borehole survey data sheet indicates the water depth of 221 feet, but the moisture log response and the HPGe log response puts the water depth at 187.5 feet. No casing correction was applied to the total gamma due to Compton downscatter interference.

\section{Radionuclides:}

No man-made radionuclide contamination was detected. This observation was confirmed using a summing technique for the spectral data.

The natural uranium concentration is below detection threshold over many intervals. The change in gross gamma at $\mathbf{4 1}$ feet is reflected by changes in potassium and thorium (from stacked response); which are indicative of geologic effects. The change in gross gamma at 56 feet is due to both a geologic change, reflected in potassium and uranium (stacked response) as well as the dual casing change. Note that the use of the normal uranium signal is difficult due to the high statistical deviations and the high detection threshold. The drop in gross gamma at 187.5 feet is due to the water attenuation within the well. 
RLS Spectral Gamma Ray Borehole Survey

Duratek Federal Services

Project: RCRA Drilling

Borehole: 299-W10-27
Log Date: March 15, 2001

Naturally Occúrring Radionuclides

Potassium Uranium Thorium Stacked Stacked Stacked

Total Gamma

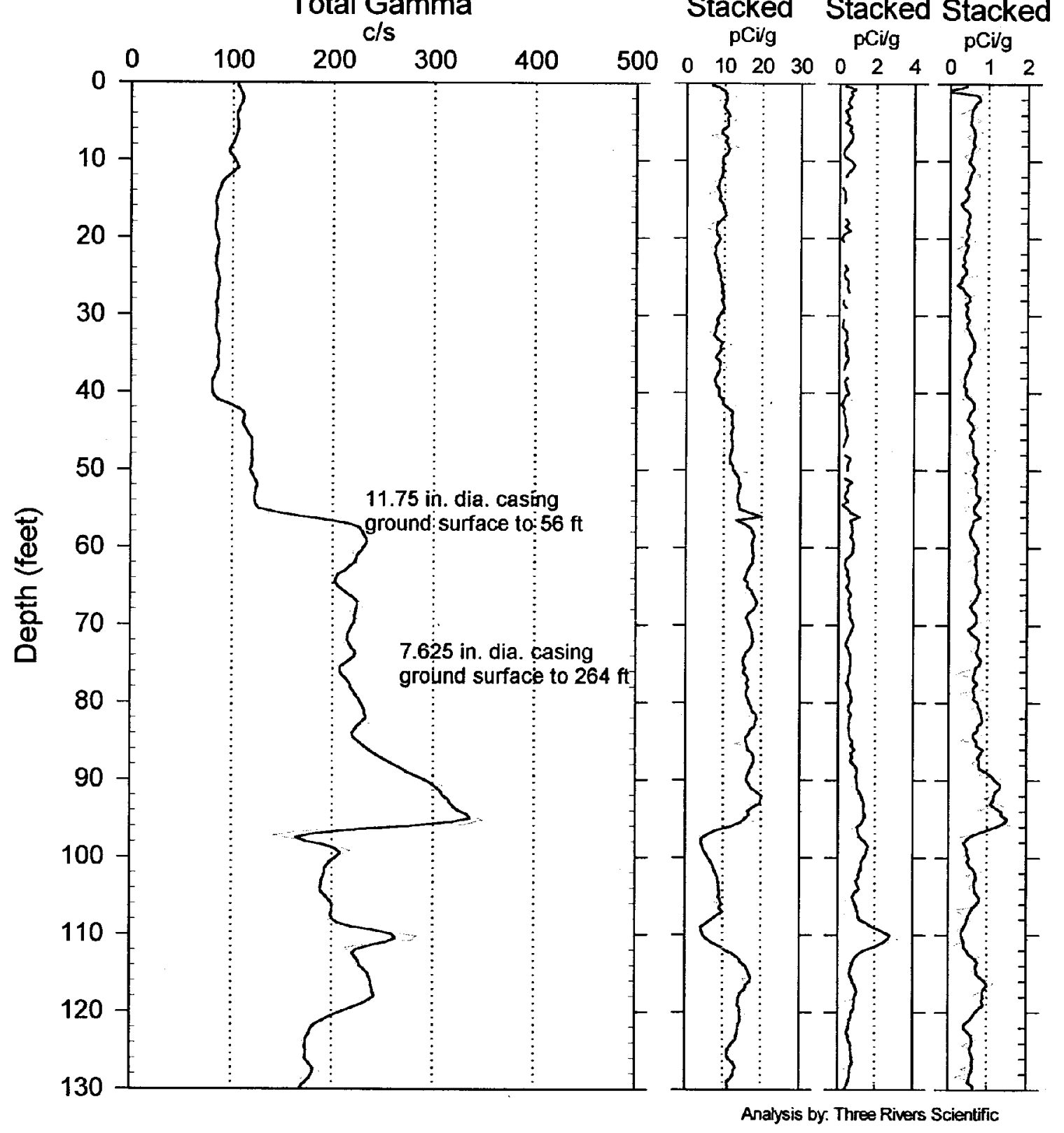




\section{RLS Spectral Gamma Ray Borehole Survey Duratek Federal Services}

Project: RCRA Drilling

Borehole: 299-W10-27

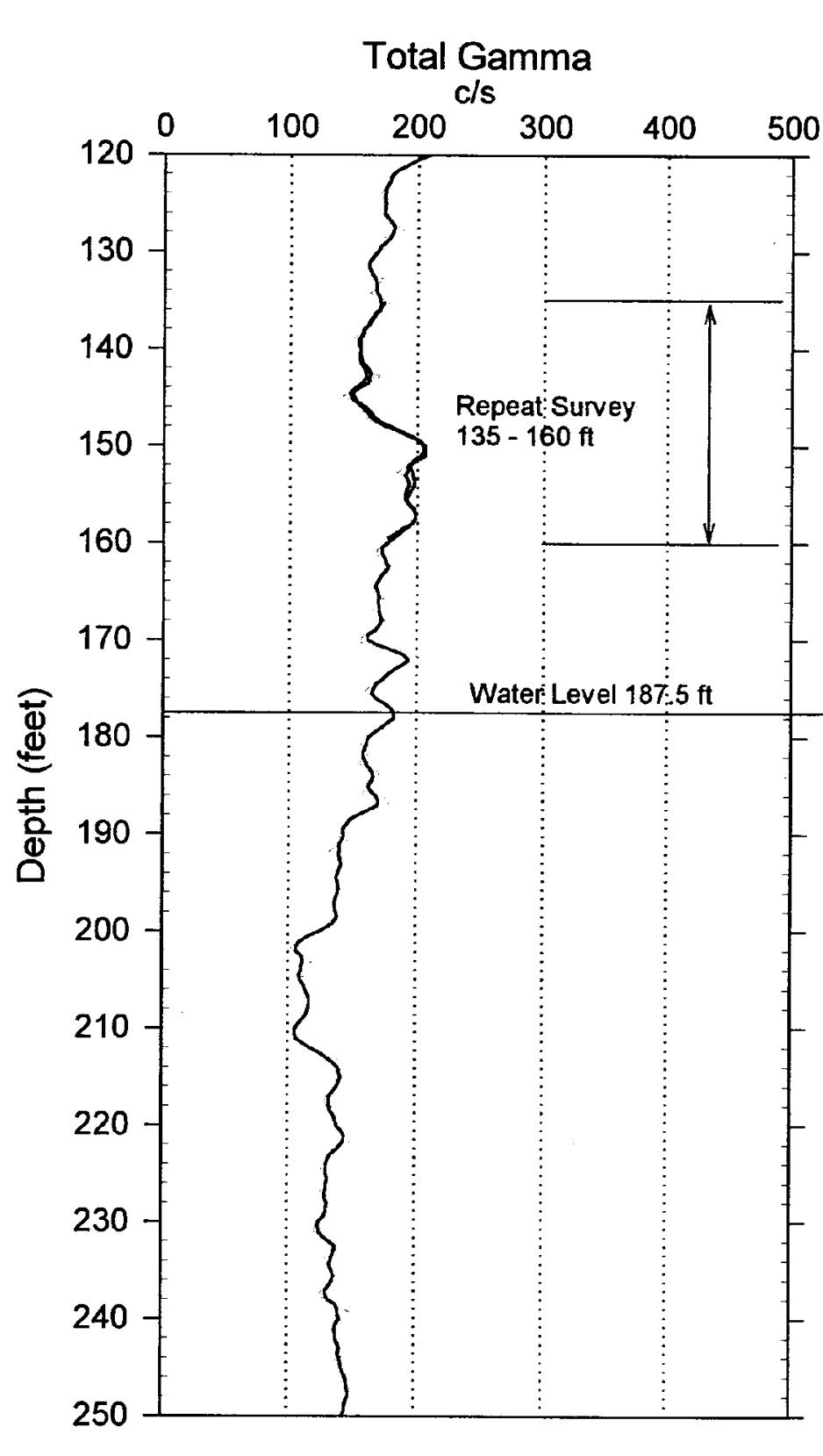

Log Date: March 15, 2001

Naturally Occurring Radionuclides

Potassium Uranium Thorium

Stacked Stacked Stacked

pCi/g pCi/g pCi/g 


\section{RLS Spectral Gamma Ray Borehole Survey \\ Duratek Federal Services}

Project: RCRA Drilling

Borehole: 299-W10-27

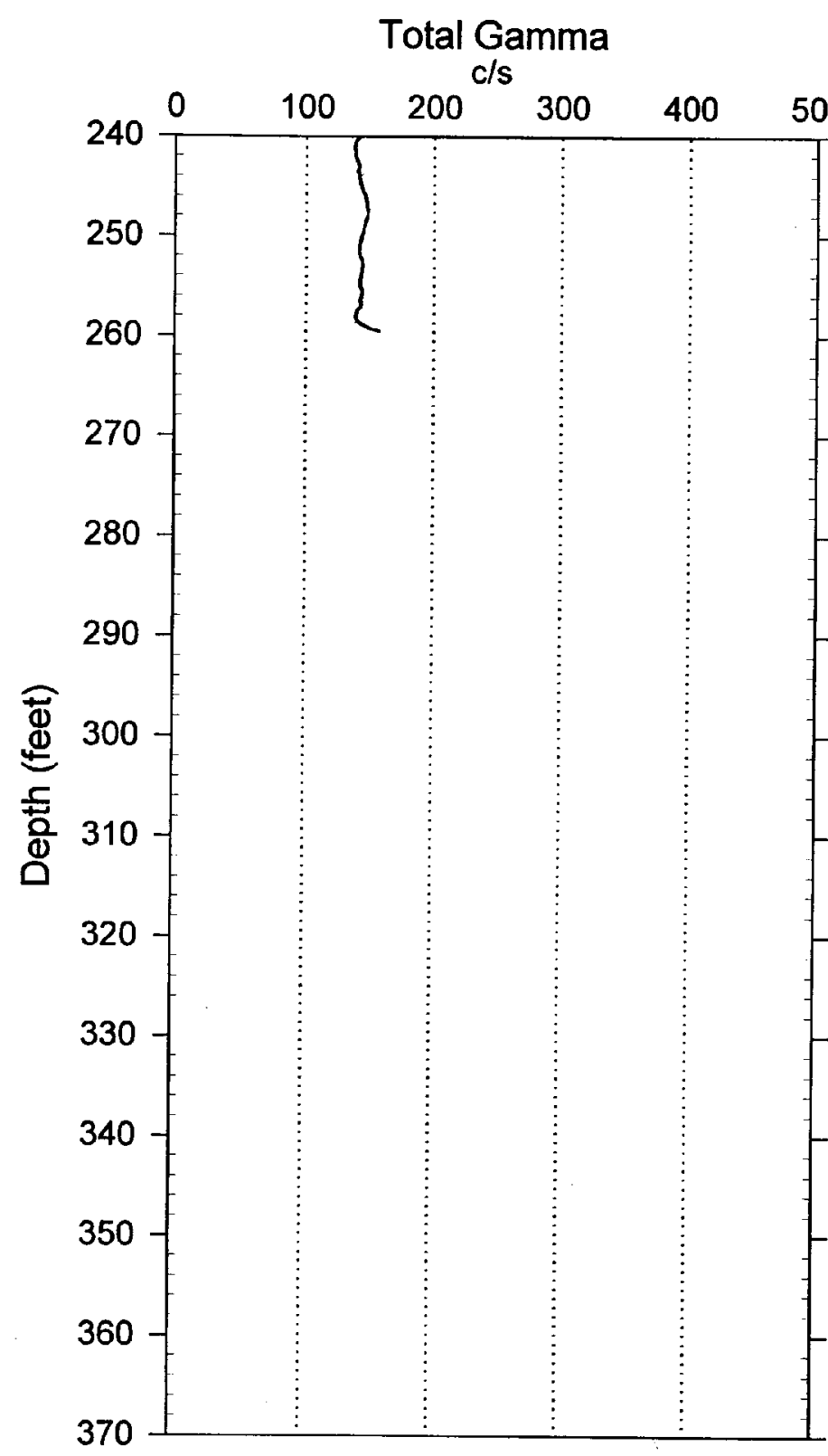

Log Date: March 15, 2001

Naturally Occurring Radionuclides

Potassium Uranium Thorium

Stacked Stacked Stacked

pCi/g pCig pCig

$\begin{array}{llllllllll}0 & 10 & 20 & 30 & 0 & 2 & 4 & 0 & 1 & 2\end{array}$

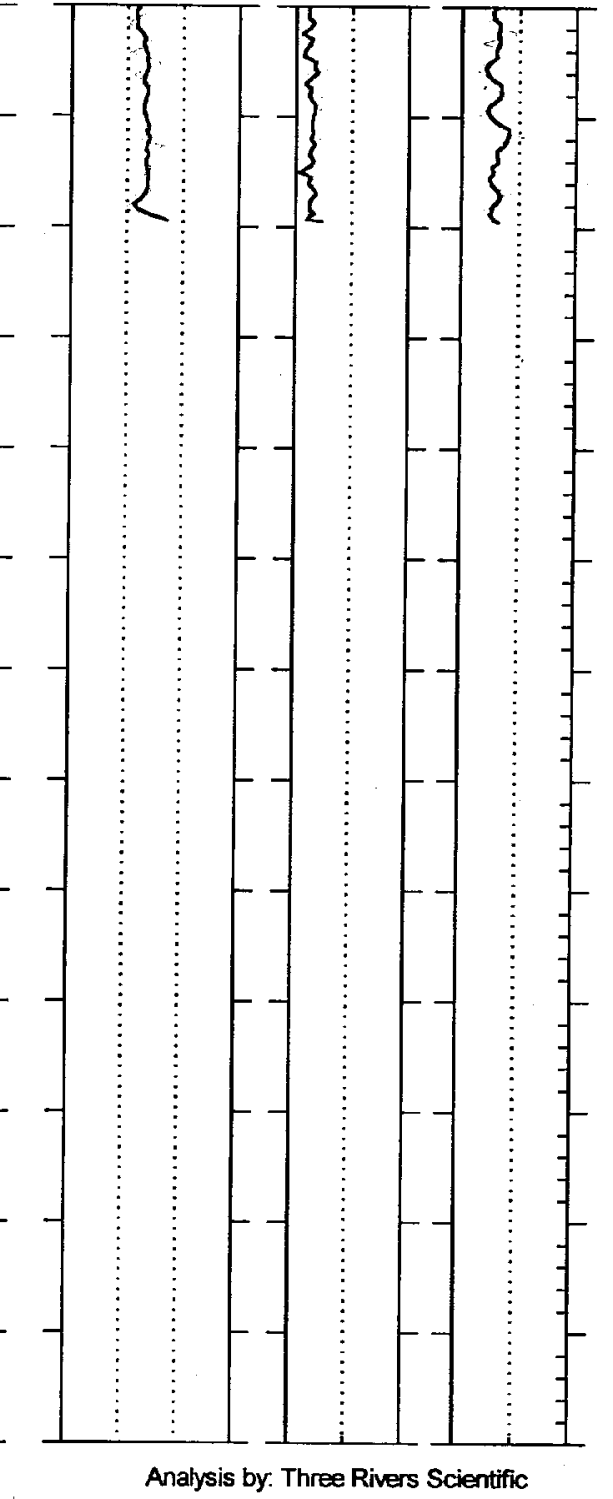




\section{Neutron-Neutron Moisture Borehole Survey \\ Duratek Federal Services, Inc.}

\section{Log Header}

Project: $\quad$ RCRA Drilling

Well: 299-W10-27

\section{Log Type: Moisture Gauge}

Borehole Information

\begin{tabular}{|c|c|c|c|}
\hline Well \# C3125 & Water Depth & $187.5^{*} \mathrm{ft}$ & Total Depth $268.5 \mathrm{ft}$ \\
\hline Elevation Reference $\underline{\mathrm{n} / \mathrm{a}}$ & Elevation & $\mathrm{n} / \mathrm{a} \quad \mathrm{ft}$ & \\
\hline Depth Reference Ground Surface & Casing Stickup & 3.58 & \\
\hline Casing Diameter 7.625 ID in & Depth Interval & 0 to $264 \mathrm{ft}$ & Thickness $\quad 0.5$ \\
\hline Casing Diameter 11.75 ID in & Depth Interval & 0 to 56 & Thickness \\
\hline
\end{tabular}

*Water level determined from Moisture Log

Logging Information

$\begin{array}{llll}\text { Log Type: } & \begin{array}{l}\text { Moisture Gauge } \\ \text { Dompatek Federal Services, Inc. }\end{array} & \\ \text { Date/Archive File Name } & \text { March 15, 2001 2M10027 } & \\ \text { Logging Engineers } & \text { D. Hollingsworth } & & \\ \text { Instrument Series } & \text { RLSM00.0 } & & \\ \text { Logging Unit } & \text { RLS-1 } & \text { Prefix } & \text { MA94 } \\ \text { Depth Interval } & 0 \text { to } 110 \mathrm{ft} & & \text { MA95 } \\ & 85 \text { to } 185 \mathrm{ft} & \text { MA96 } \\ & 180 \text { to } 189.75 \mathrm{ft} & & \end{array}$

Instrument Calibration Date July 14, 2000

Calibration Report WHC-SD-EN-TI-306, Rev. 0

Analysis Information

$\begin{array}{ll}\text { Company } & \text { Three Rivers Scientific } \\ \text { Analyst } & \text { Russ Randall } \\ \text { Date } & \text { March 26, 2001 }\end{array}$

Notes Moisture values range from $2 \%$ to $25 \%$ for depths from 56 to 187 feet. The onset of high moisture readings at 187.5 feet is due to the proximity of the water level in the borehole. Standard calibration function was applied to all logged data. Depths shallower than 56 have dual casing with a borehole diameter of 12.75 inch. Thus the depths from 0 to 56 feet do not have a possible calibration, and the plot is shown in dark green; where the standard 8 inch calibration is incorrectly applied. 


\section{Moisture Log Analysis \& Summary \\ Duratek Federal Services, Inc.}

Project: $\quad$ RCRA Drilling

Log Type: Moisture Gauge
Well ID:

Log Date: $\quad$ March 15,2001

\section{General Notes:}

The largest borehole diameter for the calibration models is an 8.64 inches borehole diameter, with .32 inch casing thickness, and the borehole diameter in these log data is 8.625 inches. Thus the standard calibration was applied to all $\log$ data. The depths shallower than 56 feet have dual casing with a borehole diameter of 12.75 inches. This diameter is beyond rigorous extrapolation and thus the standard calibration is applied, but invalid. The plot trace from 0 to 56 feet is shown in dark green.

Log data collected with a depth reference of ground surface.

System Performance Verify: The pre- and post-log verification passed performance standards, $+3.2 \%$ change from start of $\log$ to end of $\log$, in the shield verify.

Repeat Interval: Based on the repeat interval from 85 to 110 feet, the logging system performed according to specifications.

Environmental Corrections: The moisture levels have been corrected for casing thickness $(0.5$ inch) for well depths greater than 56 feet. Depths shallower than 56 feet were not casing thickness corrected since no applicable calibration exist for this borehole diameter. No formation density correction has been applied because density values are not available.

\section{Observations:}

The moisture levels show values ranging from $2 \%$ to $25 \%$ for depth intervals from 56 to 187 feet. The abnormally high readings that begin at 187.5 feet are a response to the water level at 187.5 feet. Note that geologist's information puts the water depth at 221 feet. 


\section{RLS Neutron-Neutron Moisture}

\section{Duratek Federal Services, Inc.}

Project: RCRA Drilling

Borehole: 299-W10-27

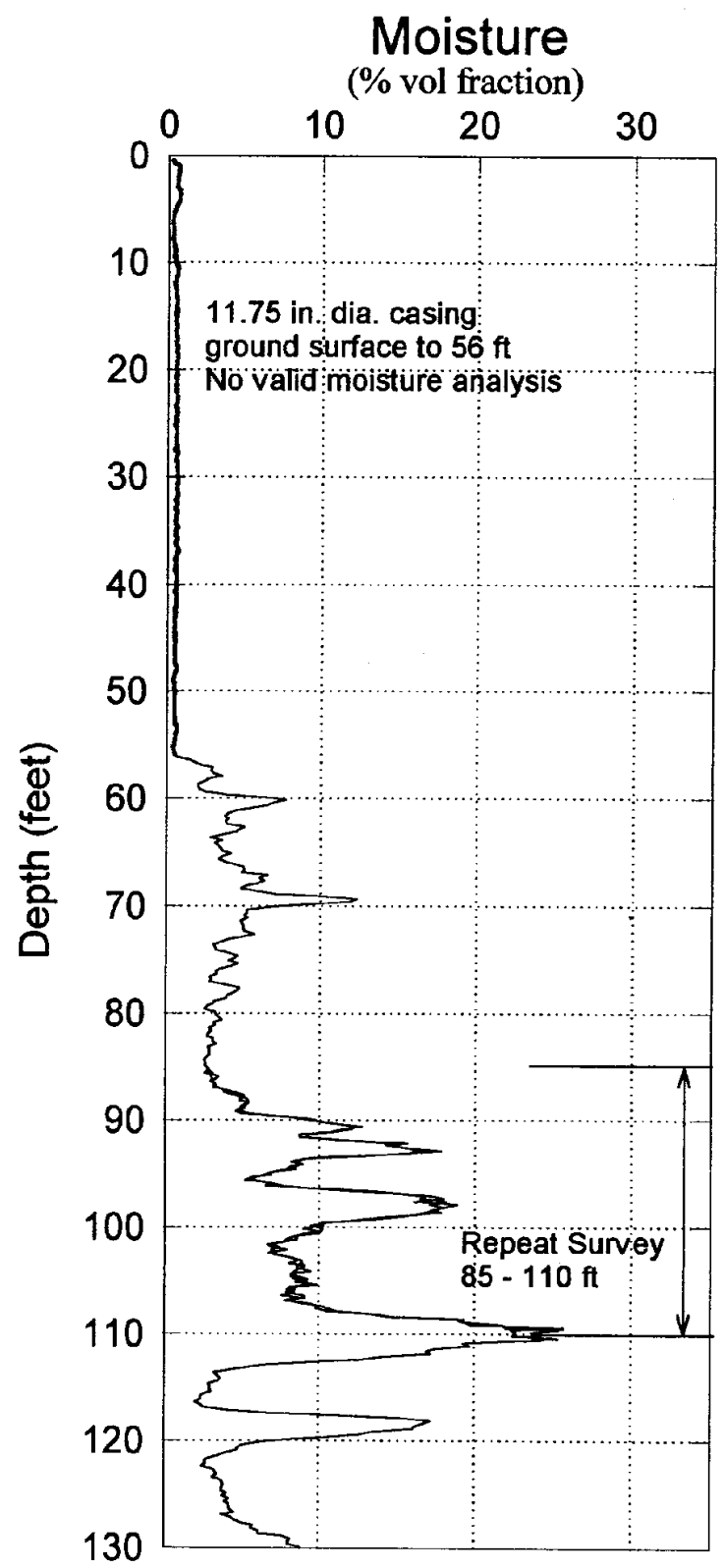

Analysis by Three Rivers Scientific
Log Date : March 15, 2001

Depth Datum : Ground Surface

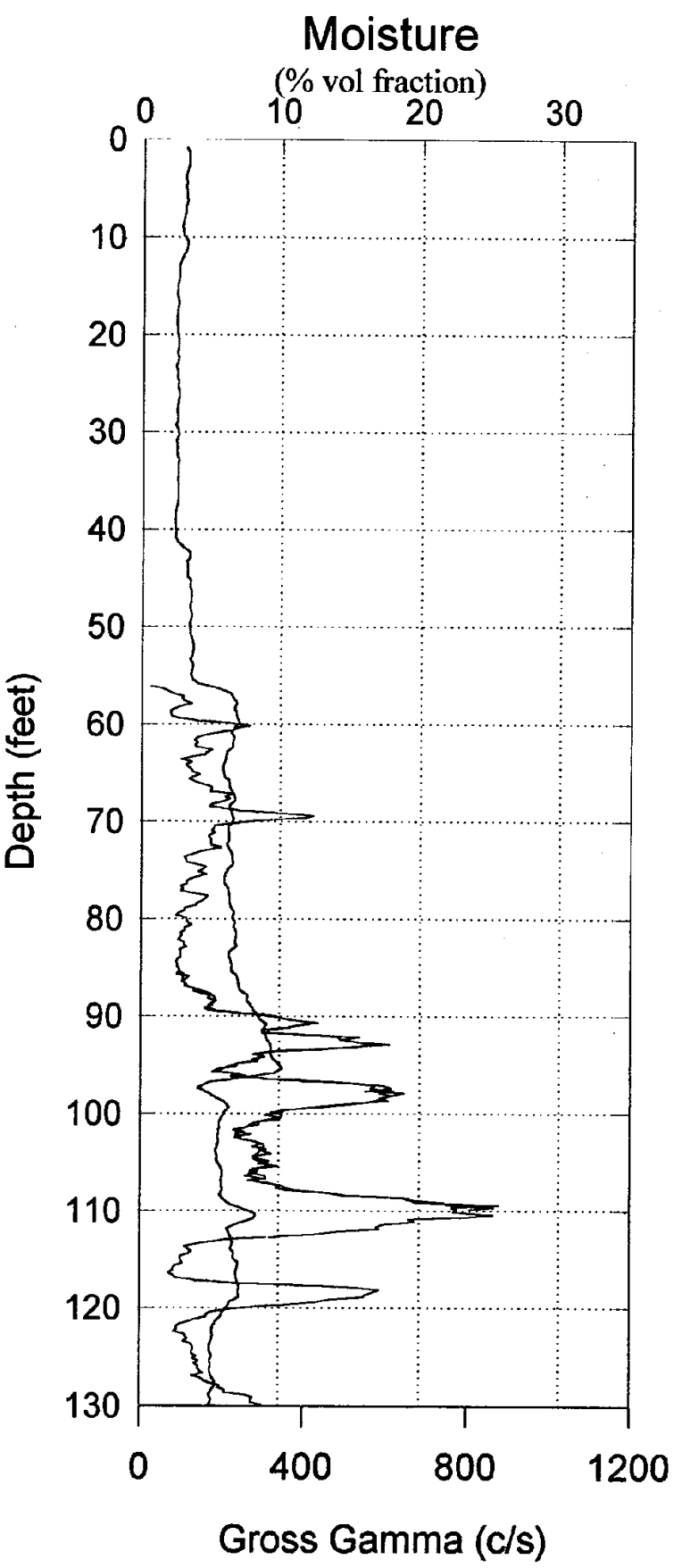

C.9 


\section{RLS Neutron-Neutron Moisture}

Duratek Federal Services, Inc.

Project: RCRA Drilling

Borehole: 299-W10-27

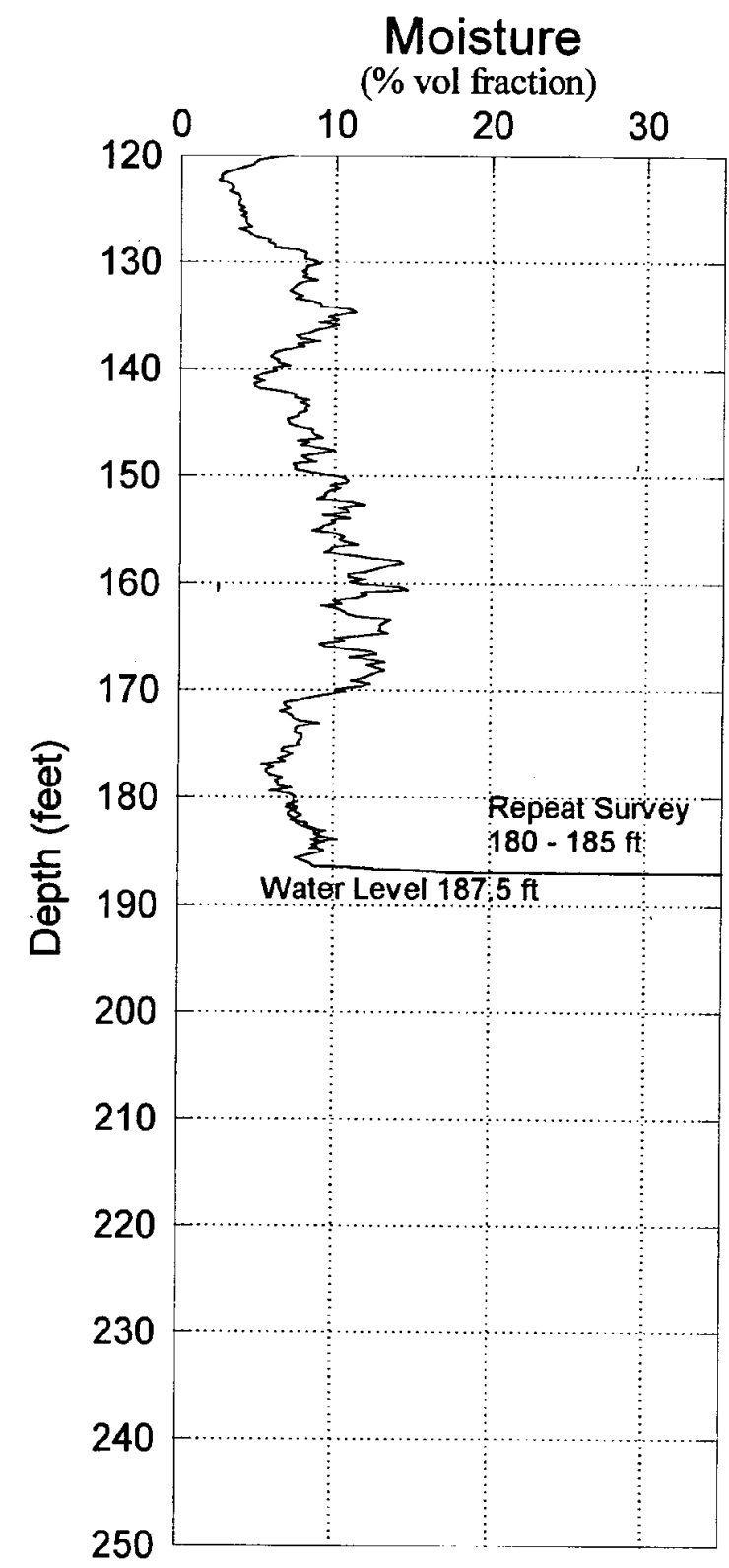

Analysis by Three Rivers Scientific
Log Date : March 15, 2001 Depth Datum : Ground Surface

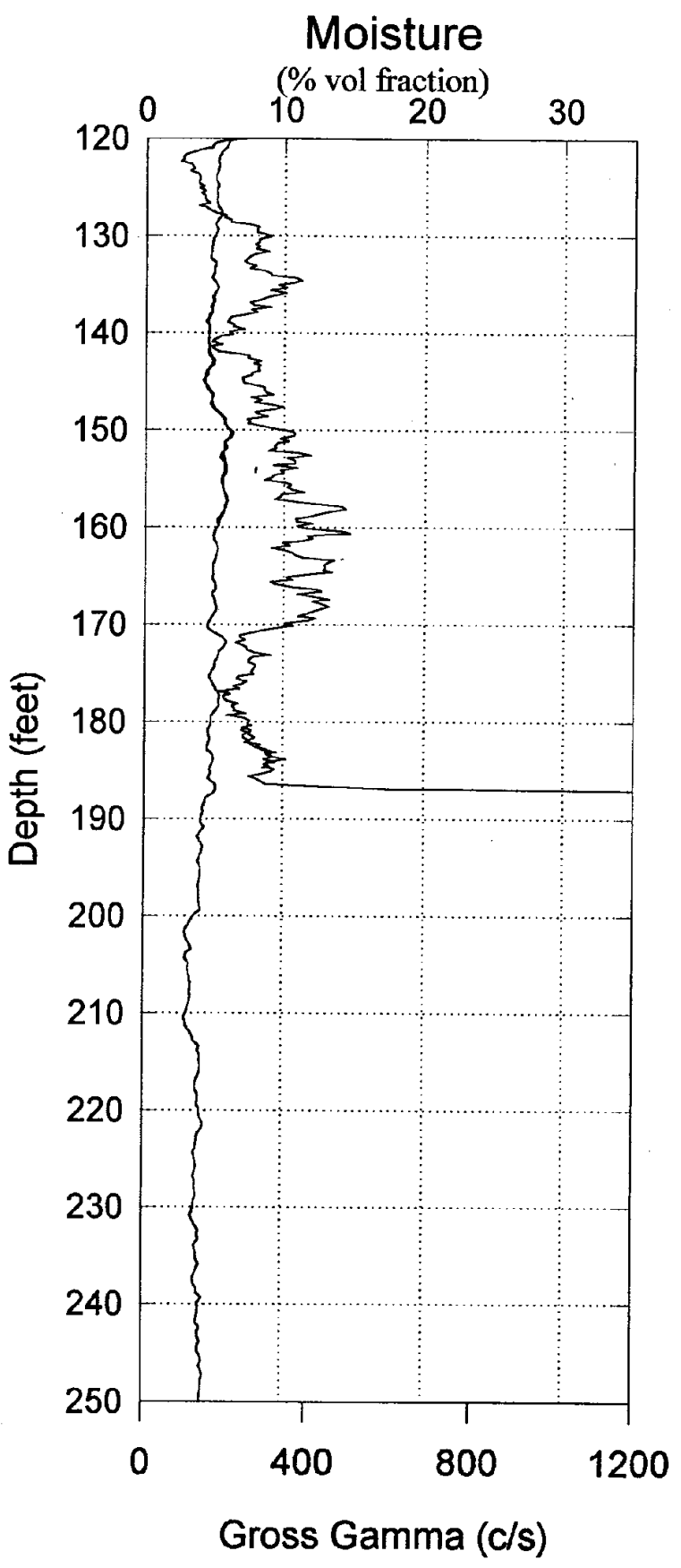

C. 10 


\section{RLS Spectral Gamma Ray Borehole Survey \\ Waste Management Federal Services}

\section{Log Header}

Project: $\quad 2000$ RCRA Drilling Well: 299-W14-16

\section{Log Type: $\quad$ HPGe Spectral Gamma Ray}

Borehole Information

\begin{tabular}{|c|c|c|c|}
\hline $\begin{array}{l}\text { Well \# } \mathrm{C} 3121 \\
\text { Elevation Reference } \mathrm{n} / \mathrm{a} \\
\text { Depth Reference } \\
\text { Casing Diameter } 9.25 \mathrm{ID} \text { in }\end{array}$ & $\begin{array}{l}\text { Water Depth } \\
\text { Elevation } \\
\text { Casing Stickup } \\
\text { Depth Interval }\end{array}$ & 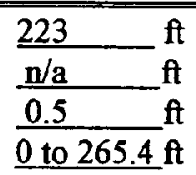 & $\begin{array}{l}\text { Total Depth } 265 \mathrm{ft} \\
\text { Thickness } 0.75 \text { in }\end{array}$ \\
\hline
\end{tabular}

\section{Logging Information}

$\begin{array}{lll}\text { Log Type } & \text { HPGe Spectral Gamma Ray } \\ \text { Company } & \text { Waste Management Federal Se } \\ \text { Date/Archive File Name } & \text { November 1, 2000 H H W } \\ \text { Logging Engineers } & \text { J Meisner, A Pearson } \\ \text { Instrument Series } & \text { RLSG07000S01.0 } \\ \text { Logging Unit } & \text { RLS-1 } \\ \text { Depth Interval } & 0 \text { to 125 f } & \text { Prefix } \\ & 100 \text { to 265.4 ft } \\ & & \text { Prefix } \\ \text { Instrument Calibration Date } & \text { Oct 6, 2000 } \\ \text { Calibration Report } & \text { WHC-SD-EN-TI-292, Rev 0 }\end{array}$

Analysis Information

$\begin{array}{ll}\text { Company } & \text { Three Rivers Scientific } \\ \text { Analyst } & \text { Russ Randall } \\ \text { Date } & \text { November 24, 2000 }\end{array}$

Notes No man-made contamination was detected. Two depth intervals 10 to 100 and 120 to 265 feet) the natural uranium levels are below detection threshold. The water level from 223 to 265 also reduces the gross gamma and raises detection thresholds. 


\section{RLS Spectral Gamma Ray Borehole Survey}

Waste Management Federal Services

Project: 2000 RCRA Drilling

Borehole: 299-W14-16
Log Date: November 1, 2000 Naturally Occurring Radionuclides

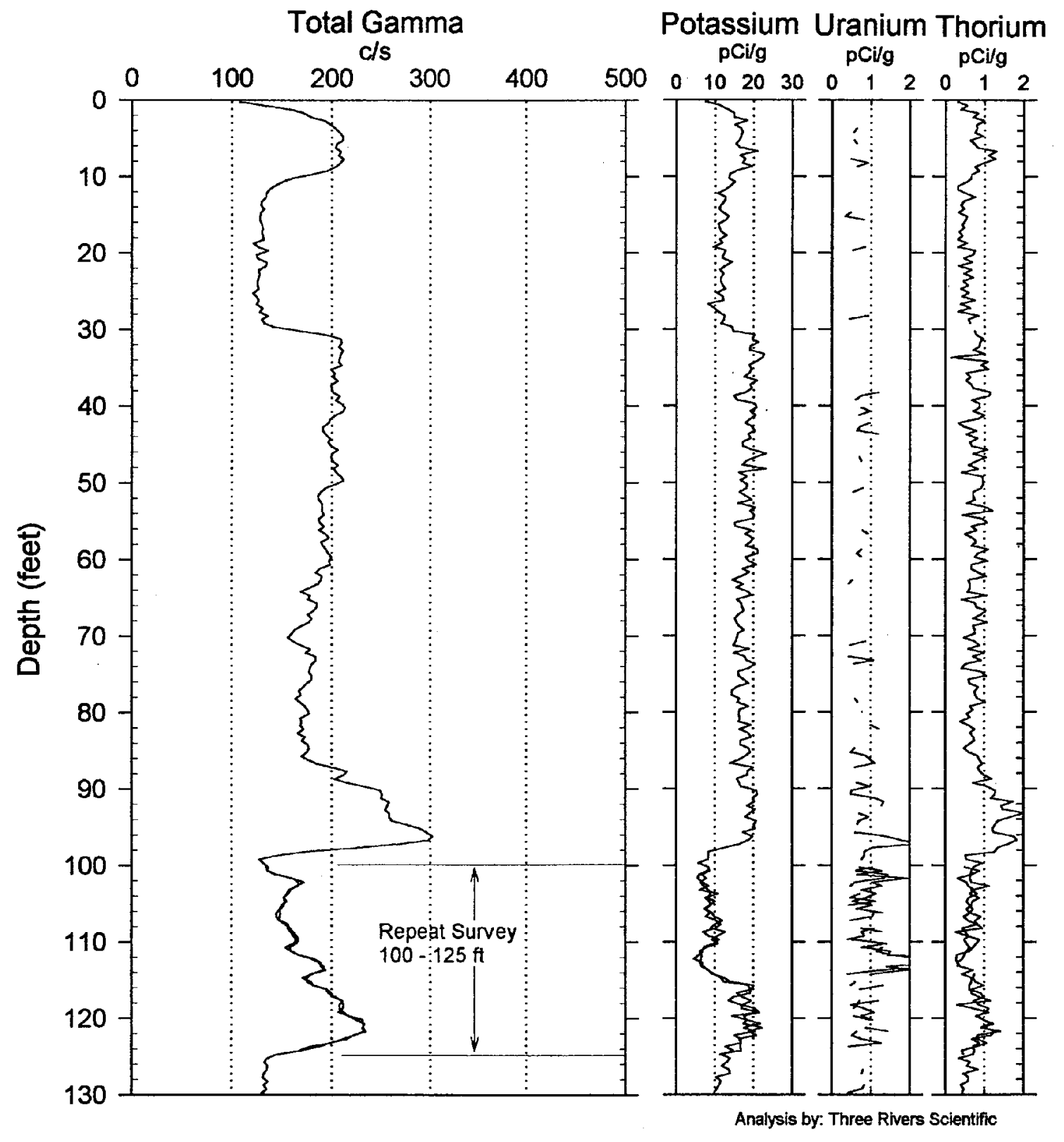




\section{RLS Spectral Gamma Ray Borehole Survey \\ Waste Management Federal Services}

Project: 2000 RCRA Drilling

Borehole: 299-W14-16
Log Date: November 1, 2000

Naturally Occurring Radionuclides

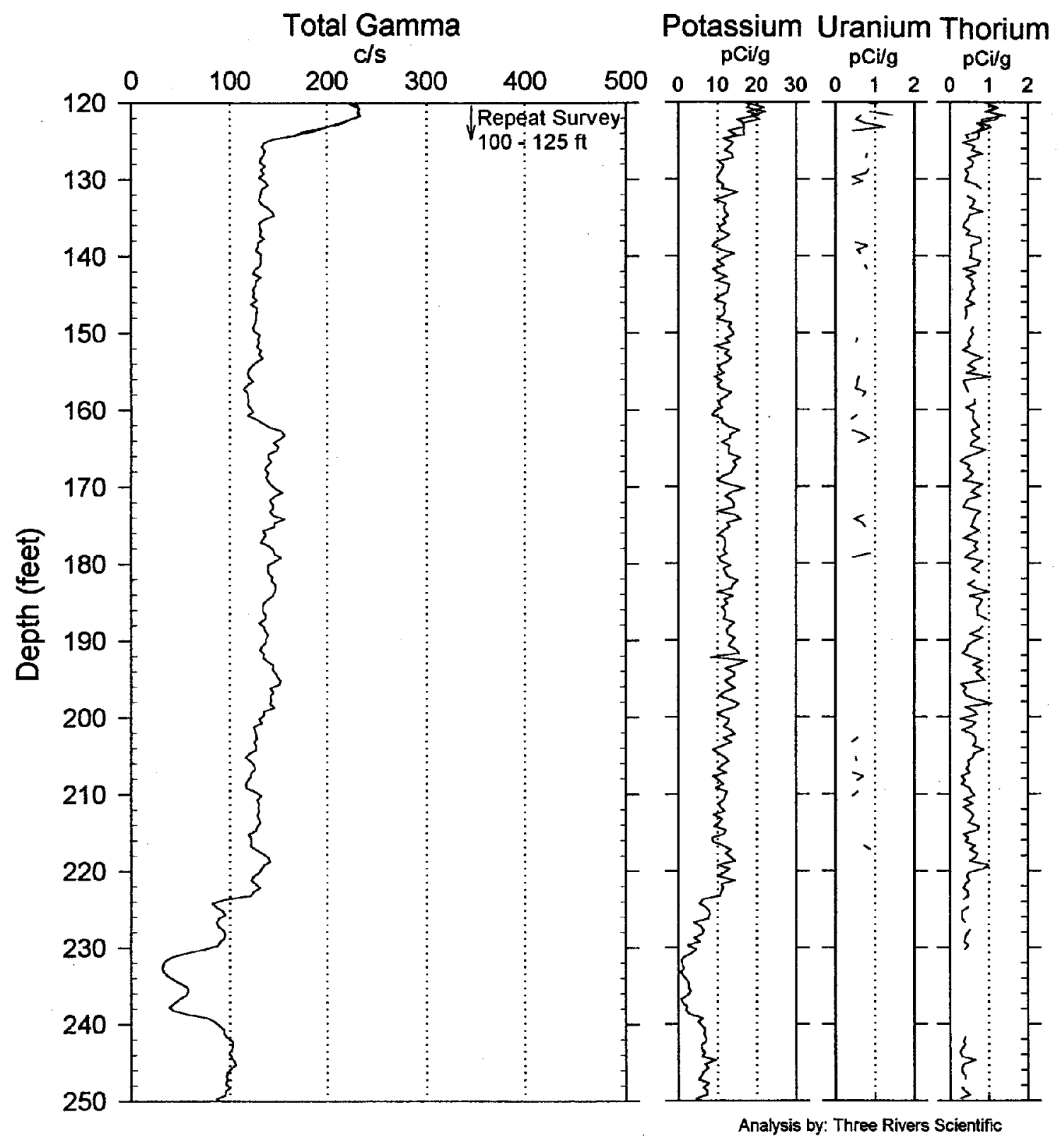




\section{RLS Spectral Gamma Ray Borehole Survey Waste Management Federal Services}

Project: 2000 RCRA Drilling

Borehole: 299-W14-16

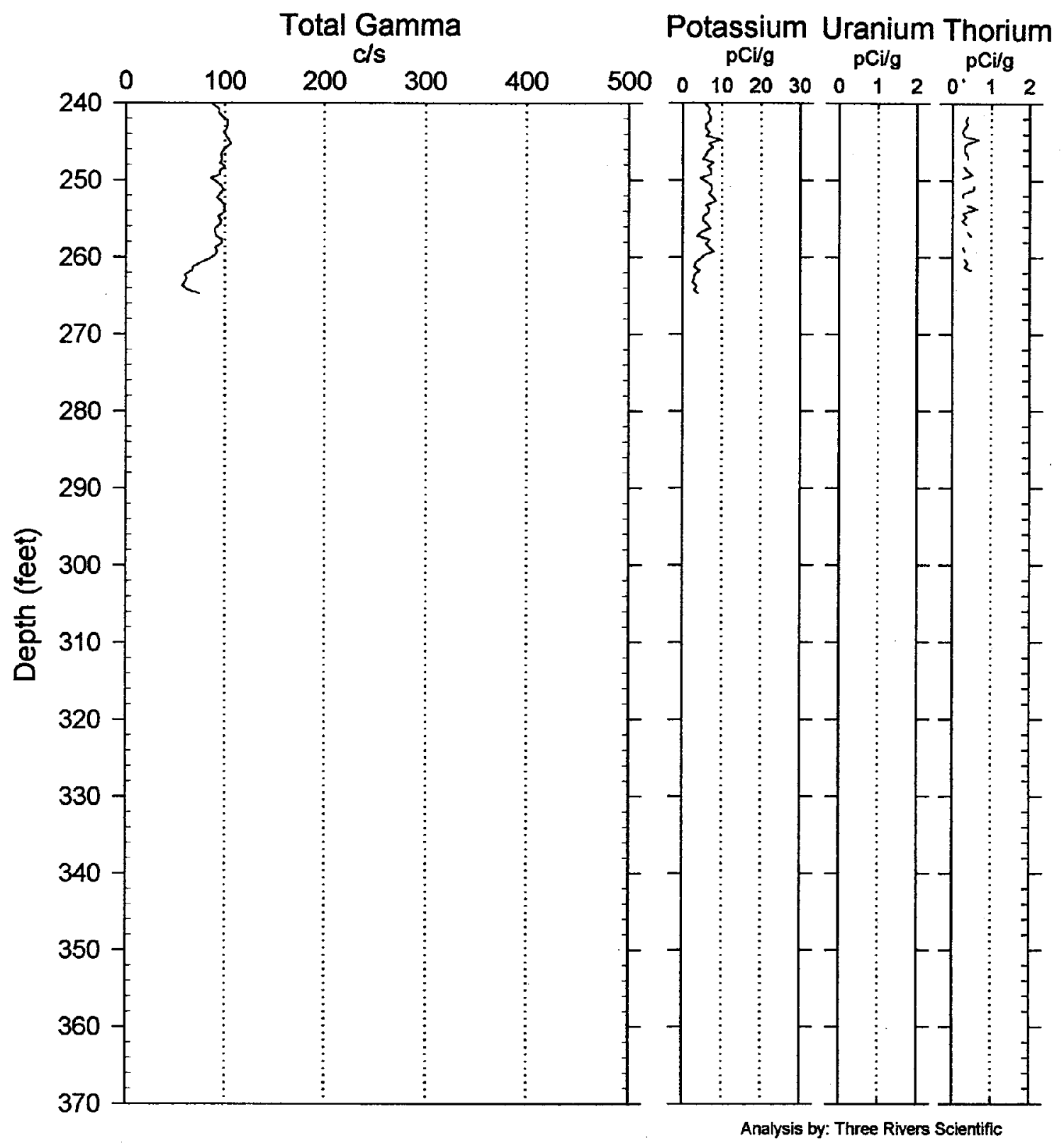

Log Date: November 1, 2000

Naturally Occurring Radionuclides 


\section{Spectral Gamma Ray Log Analysis \& Summary \\ Waste Management Federal Services}

Project: $\quad 2000$ RCRA Drilling

Log Type: $\quad$ HPGe Spectral Gamma Ray
Well:

299-W14-16

Log Date: November 1, 2000

\section{General Notes:}

Total gamma is a response to geologic concentrations of natural radionuclides. A change in sensitivity of gross gamma to geologic concentrations of natural radionuclides occurd at the water level (223 feet).

Log data were collected with a depth reference of ground surface.

System Performance Verify: The pre- and post-log verification passed performance standards; a $-0.01 \%$ change was observed in the gross. The FWHM of the $583 \mathrm{keV}$ photo peak was also within specifications for pre- and post$\log$ verification.

Repeat Interval: Based on the repeat interval, the logging system performed as per specifications.

Environmental Corrections: All radionuclide concentrations have been corrected for casing attenuation (entire well). Water correction was applied to depths deeper than 223 feet. No casing correction was applied to the total gamma due to Compton downscatter interference.

\section{Radionuclides:}

No man-made radionuclide contamination was detected.

The natural uranium concentration is below detection threshold from 0 to 100 feet, and from 120 to 265 feet. The changes in gross gamma from 85 to 125 feet are reflected by changes in potassium, uranium, and thorium; which is indicative of geologic effects. 


\section{Neutron-Neutron Moisture Borehole Survey \\ Waste Management Federal Services}

\section{Log Header}

Project: 2000 RCRA Drilling Well: 299-W14-16

\section{Log Type: Moisture Gauge}

Borehole Information

\begin{tabular}{|c|c|c|c|}
\hline Well \# C3121 & Water Depth & $\underline{223}$ & Total Depth $265 \mathrm{ft}$ \\
\hline Elevation Reference $\underline{\mathbf{n} / \mathbf{a}}$ & Elevation & $\mathbf{n} / \mathbf{a}$ & \\
\hline Depth Reference Ground Surface & Casing Stickup & 0.5 & \\
\hline Casing Diameter 9.25 ID in & Depth Interval & 0 to $265.4 \mathrm{ft}$ & Thickness \\
\hline
\end{tabular}

\section{Logging Information}

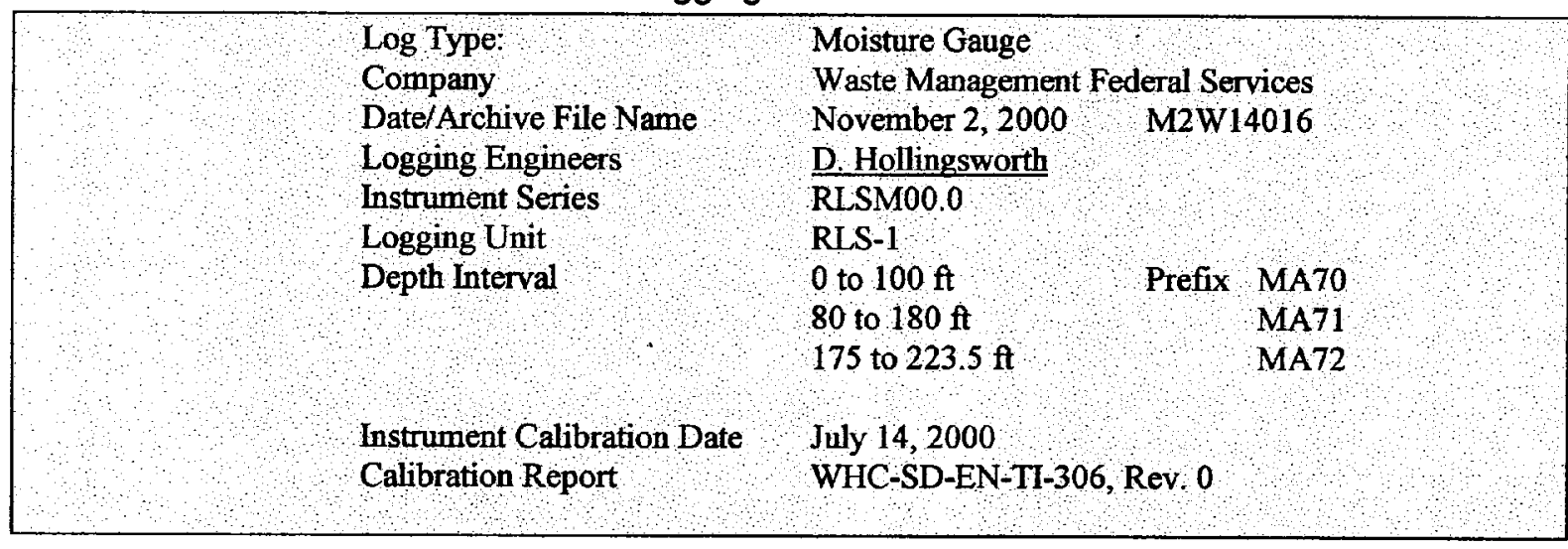

Analysis Information

$\begin{array}{ll}\text { Company } & \text { Three Rivers Scientific } \\ \text { Analyst } & \text { Russ Randall } \\ \text { Date } & \text { November 24, 2000 }\end{array}$

Notes Moisture values range from $2 \%$ to $16 \%$ for the depths logged. The onset of high readings at 223 feet is due to the proximity of the water level in the borehole. No valid calibration is available for the 10.75 inch OD casing, thus the calibration function was extrapolated from the model cases to this diameter. A casing thickness correction was applied prior to computation of the volume moisture. 


\section{RLS Neutron-Neutron Moisture}

\section{Waste Management Federal Services}

Project: 2000 RCRA Drilling

Borehole: 299-W14-16
Log Date : November 2, 2000

Depth Datum : Ground Surface

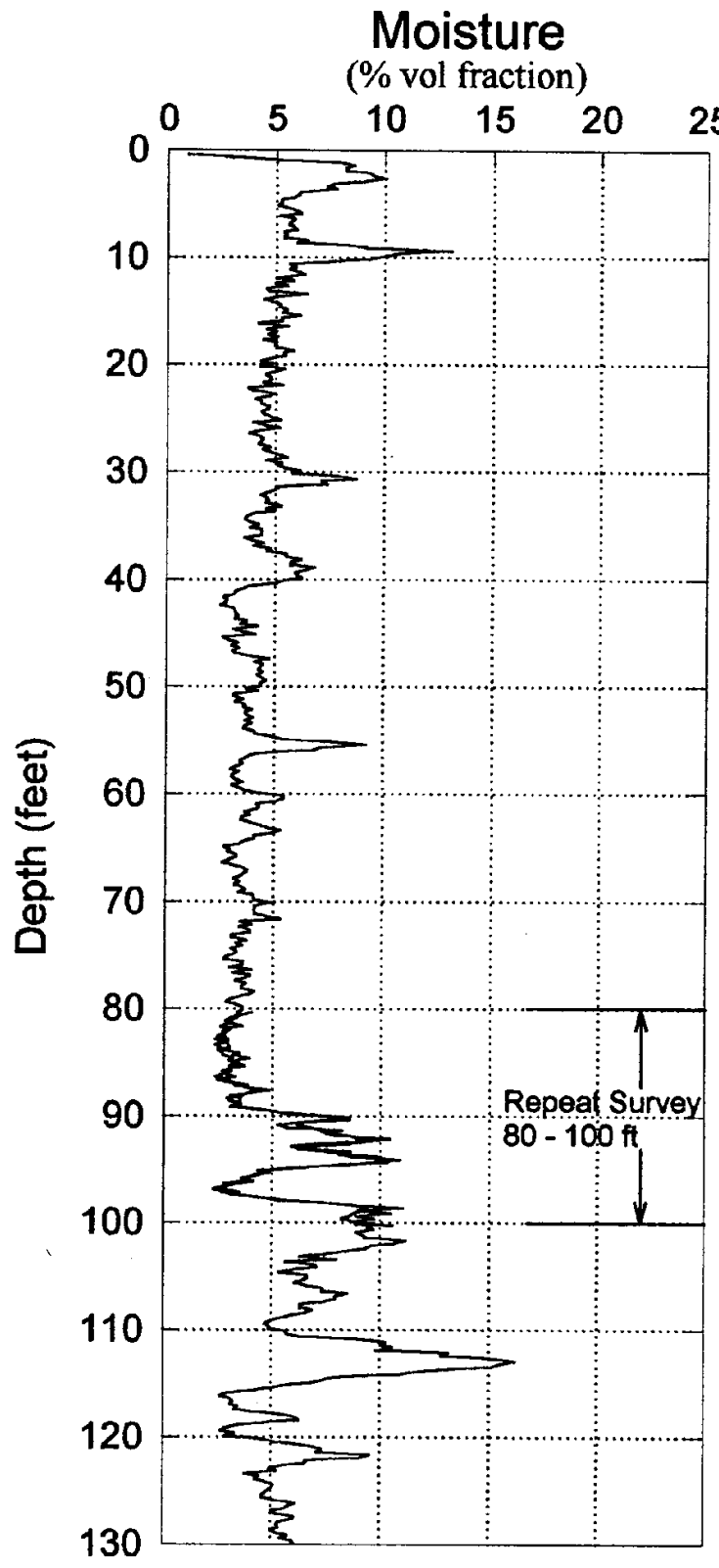

Analysis by Three Rivers Scientific

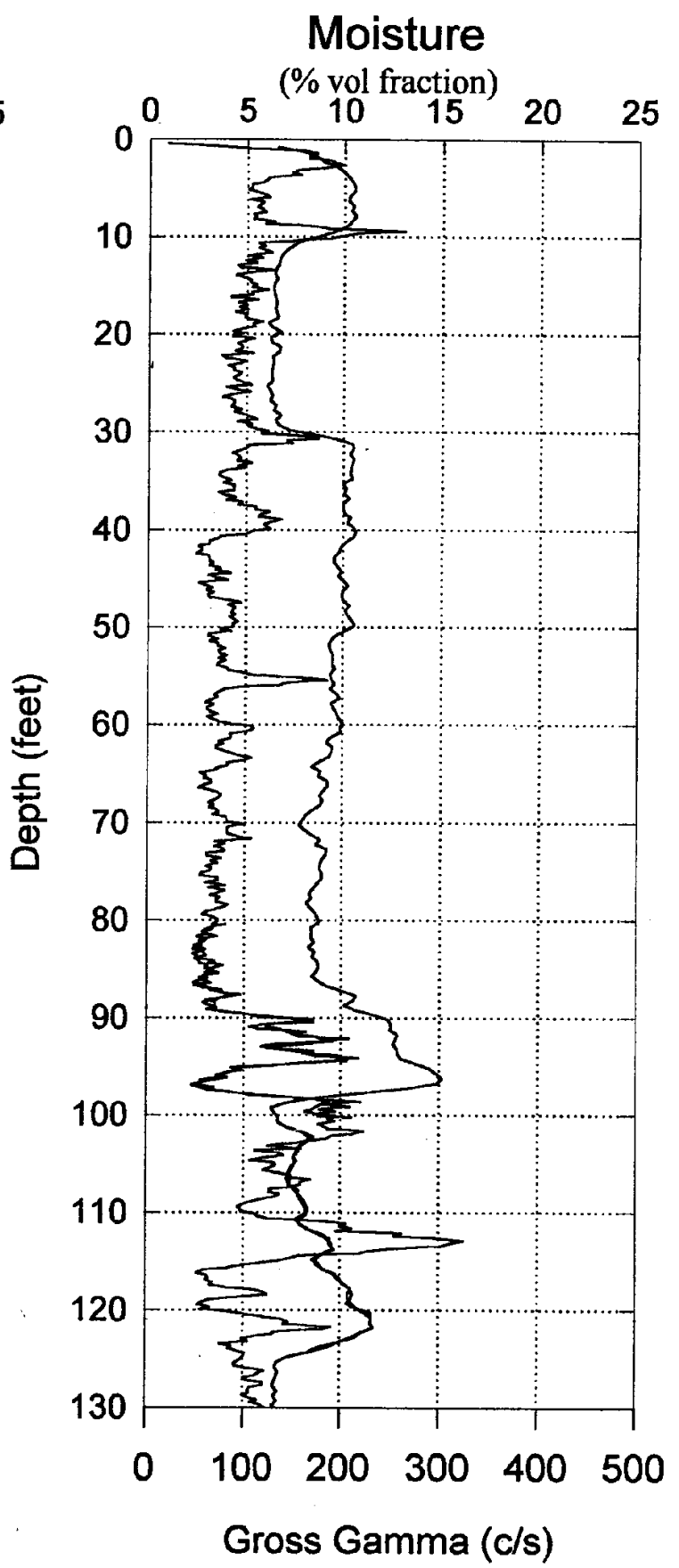




\section{RLS Neutron-Neutron Moisture}

\section{Waste Management Federal Services}

Project: 2000 RCRA Drilling Borehole: 299-W14-16

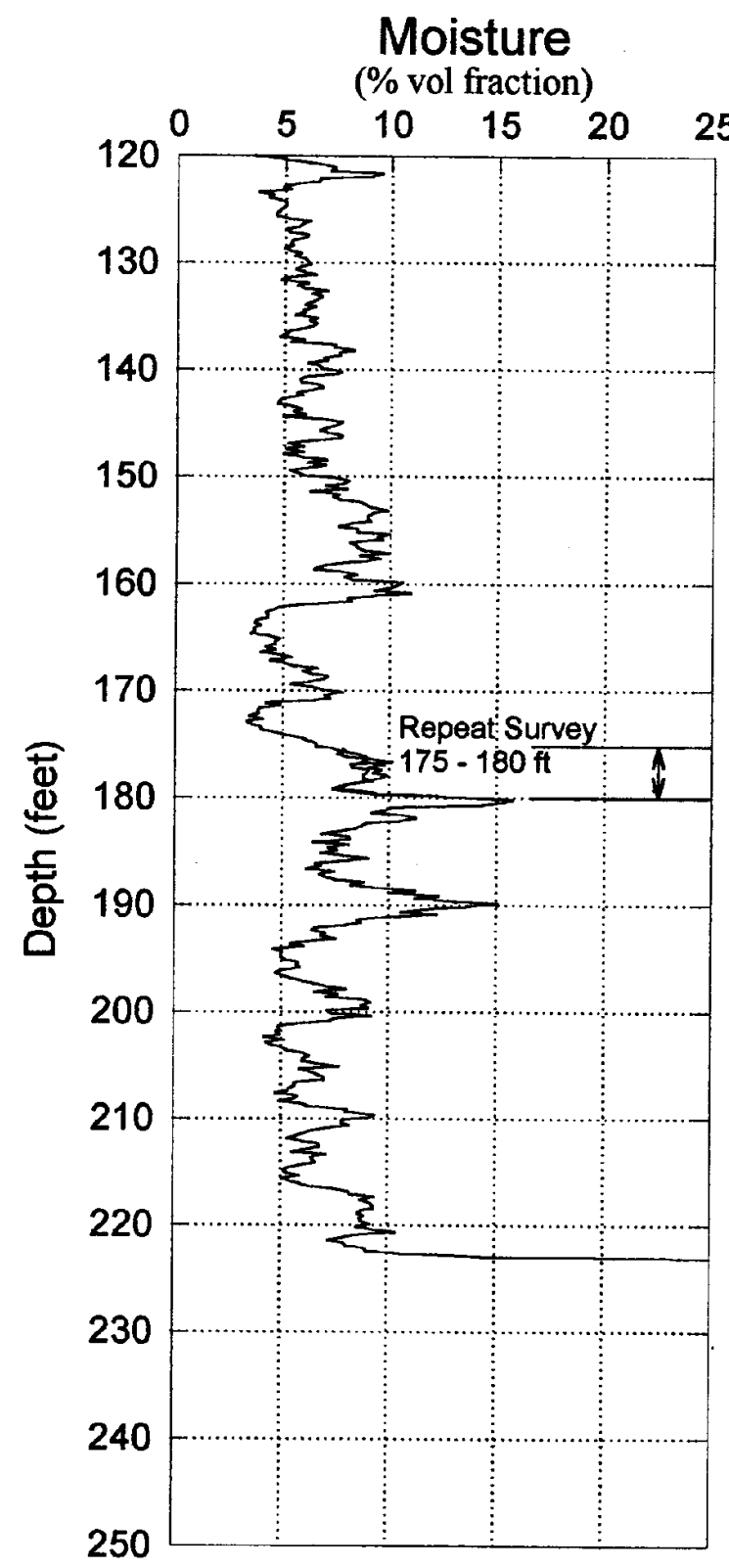

Analysis by Three Rivers Scientific
Log Date : November 2, 2000 Depth Datum : Ground Surface

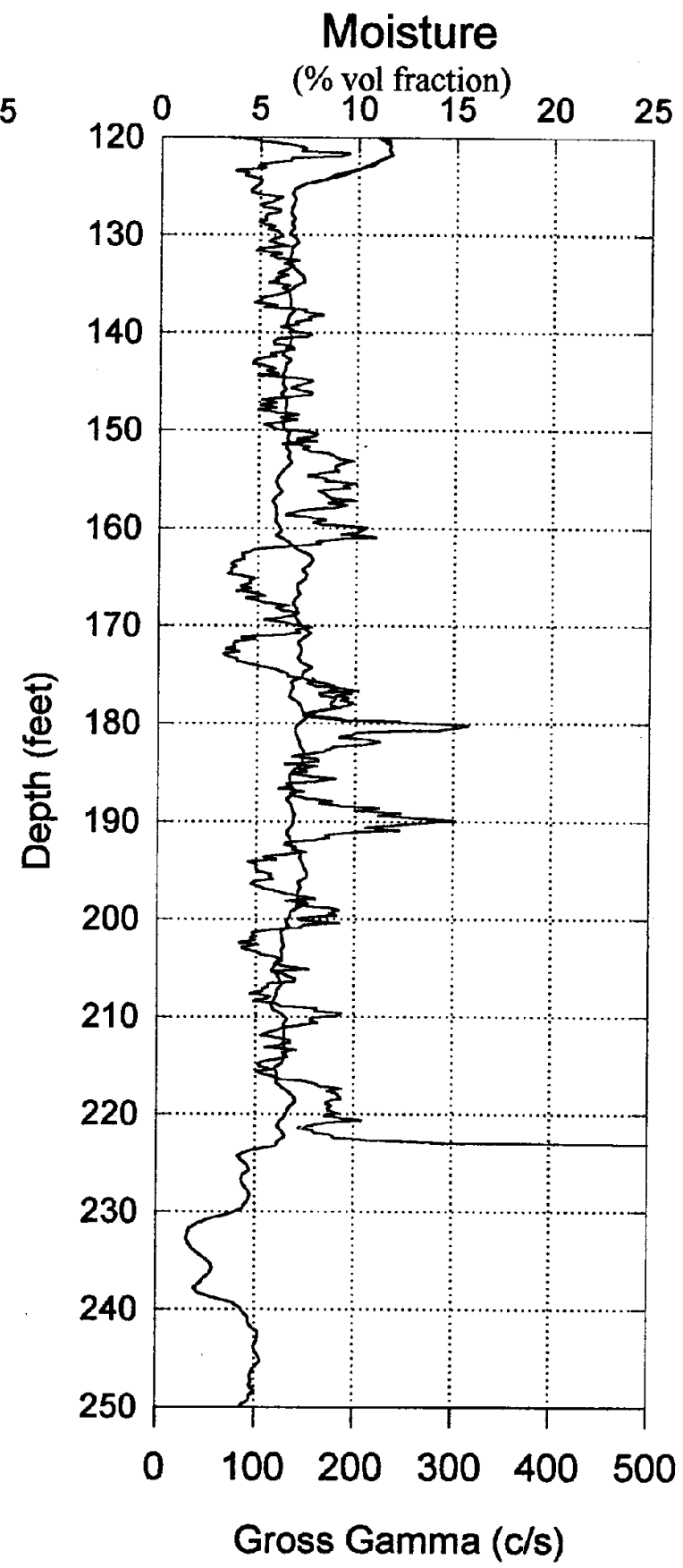




\section{Moisture Log Analysis \& Summary \\ Waste Management Federal Services}

Project: $\quad 2000$ RCRA Drilling

Well ID:

299-W14-16

Log Type: Moisture Gauge

Log Date: November 2, 2000

\section{General Notes:}

The calibration coefficients were generated by extrapolation from the actual model standard diameters of 6.56 and 8.64 inch diameters. Thus the accuracy of the calibration is to be determined.

Log data were collected with a depth reference of ground surface.

System Performance Verify: The pre- and post-log verification passed performance standards; +0.10 change from start of $\log$ to end of $\log$, in the shield verify.

Repeat Interval: Based on the repeat interval from 80 to 100 feet and 175 to 180 feet, the logging system performed according to specifications.

Environmental Corrections: The moisture levels have been corrected for casing thickness ( 0.75 inch) for all well depths logged. No formation density correction has been applied because density values are not available.

\section{Observations:}

The moisture levels show values ranging from $2 \%$ to $16 \%$ for the depth interval from 2 feet to 223 feet. The abnormally high readings that begin at 223 feet are a response to the water level at 223 feet.

Thin wetter zones exist at 10,30, and 55 feet. A highly laminated structure of wetter zones bounded by driet zones exists from 90 feet to 124 feet. Over this interval ( 90 to 124 feet) there is a good correlation between the gross gamma and the moisture structure, which is indicative of geologic variations.

Variable moisture structure shows from 162 to 220 feet. Over this depth interval, there is no good correlation with the gross gamma signature. Therefore, moisture content is sensitive to the geologic structure over this interval, while the changes in natural radionuclides are not sensitive to the geologic structure. 


\section{RLS Spectral Gamma Ray Borehole Survey \\ Waste Management Federal Services}

\section{Log Header}

Project: $\quad 2000$ RCRA Drilling

Well: 299-W14-17

Log Type: HPGe Spectral Gamma Ray

Borehole Information

\begin{tabular}{|c|c|c|}
\hline Well \# C3121 & Water Depth & Total Depth $\underline{264.3 \mathrm{ft}}$ \\
\hline Elevation Reference n/a & Elevation & \\
\hline Depth Reference Ground Surface & Casing Stickup 0.5 & \\
\hline Casing Diameter $10.125 \mathrm{ID}$ in & Depth Interval 0 to $20.6 \mathrm{ft}$ & Thickness \\
\hline Casing Diameter $7.625 \mathrm{ID}$ in & Depth Interval 0 to $264.3 \mathrm{ft}$ & Thickness \\
\hline
\end{tabular}

Logging Information

Log Type:
Company
Date/Archive File Name
Logging Engineers
Instrument Series
Logging Unit
Depth Interval
Instrument Calibration Date
Calibration Report

HPGe Spectral Gamma Ray

Waste Management Federal Services

October 17,2000

H2W 14017

D.Hollingsworth

RLSG07000S01.0

RLS-1

0 to $200 \mathrm{ft}$.

Prefix $A 700$

180 to $260 \mathrm{ft}$

Prefix A701

Oct 6,2000

WHC-SD-EN-TI-292, Rov 0.

Analysis Information

Company
Analyst
Date $\quad \begin{aligned} & \text { Three Rivers Scientific } \\ & \text { Russ Randall }\end{aligned}$

Notes No man-made contamination was detected. Two depth intervals $(0$ to 20 and 222 to 265 feet) the natural uranium levels are below detection threshold. The dual casing from 0 to 20 feet reduces the gross gamma and raises detection thresholds. The water level from 222 to 265 also reduces the gross gamma and raises detection thresholds. 


\section{RLS Spectral Gamma Ray Borehole Survey Waste Management Federal Services}

Project: 2000 RCRA Drilling

Borehole: 299-W14-17
Log Date: October 17, 2000 Naturally Occurring Radionuclides

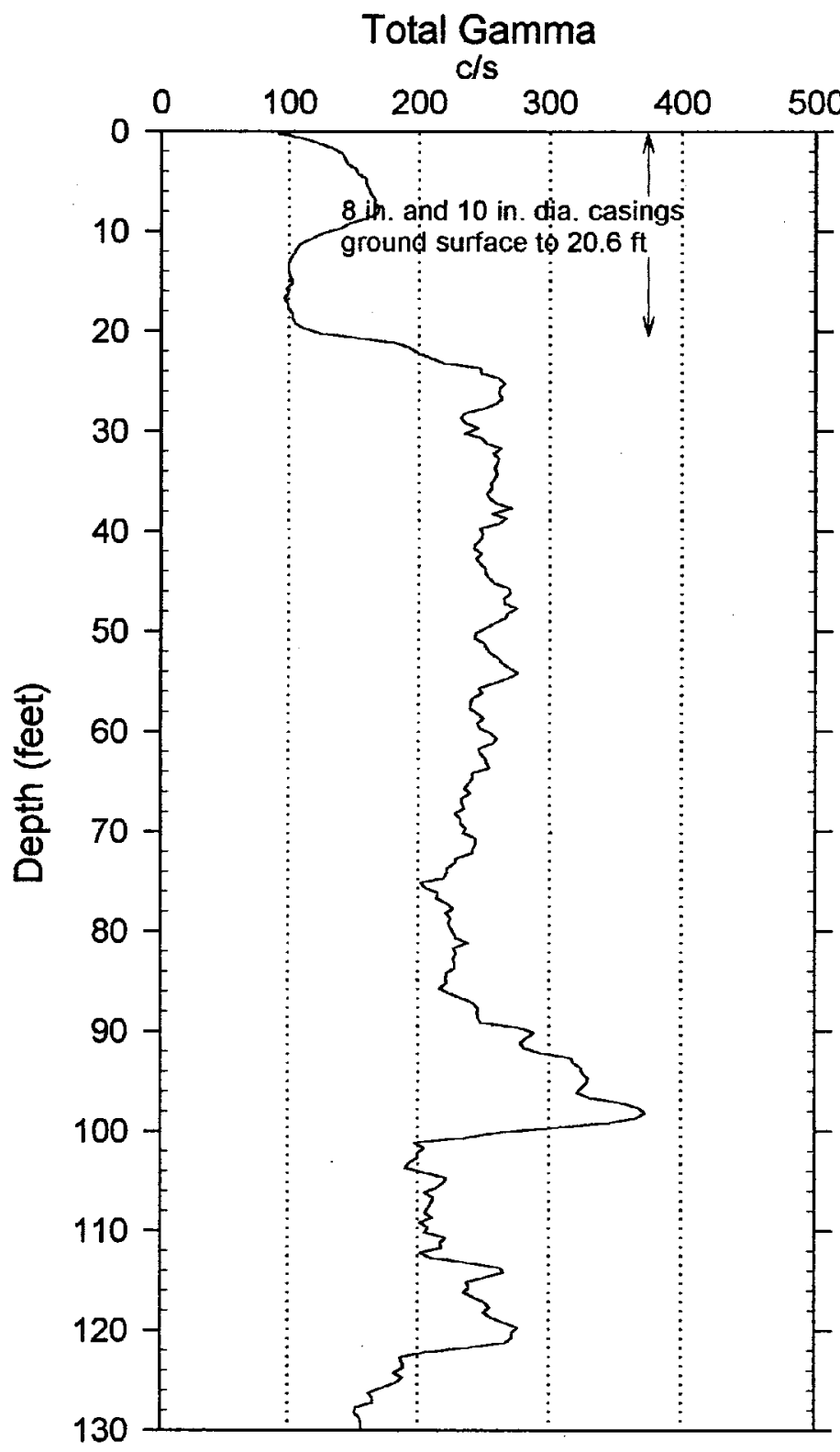

Potassium Uranium Thorium

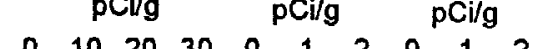

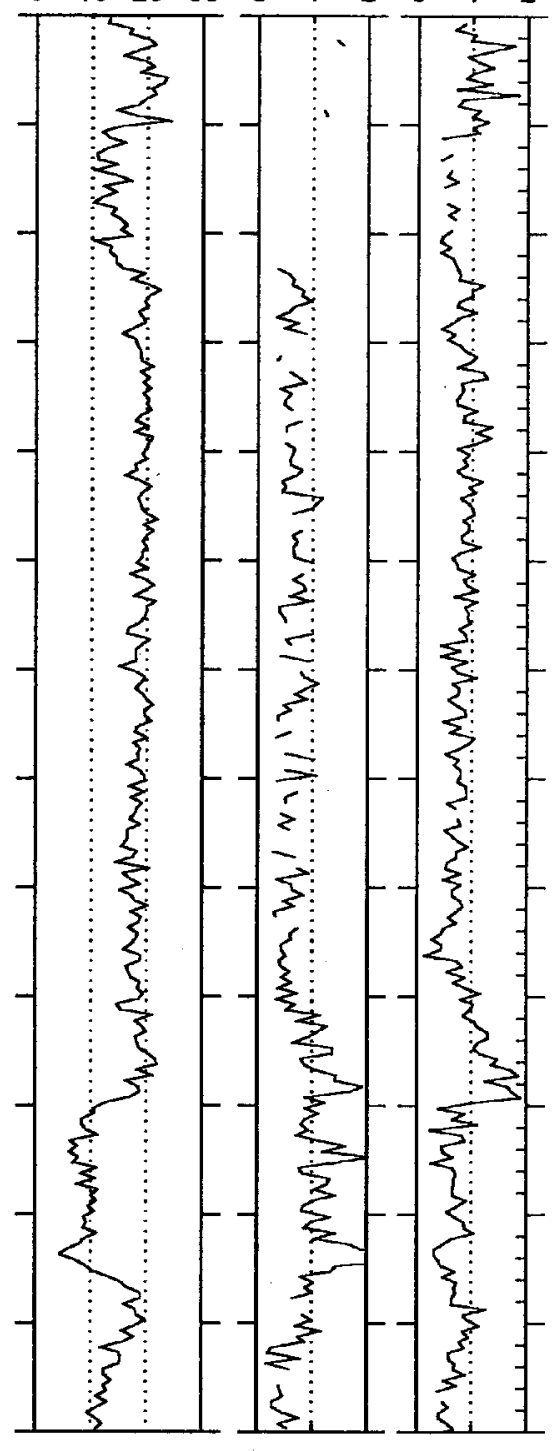

Analysis by: Three Rivers Scientific 


\section{RLS Spectral Gamma Ray Borehole Survey Waste Management Federal Services}

Project: 2000 RCRA Drilling

Borehole: 299-W14-17
Log Date: October 17, 2000 Naturally Occurring Radionuclides

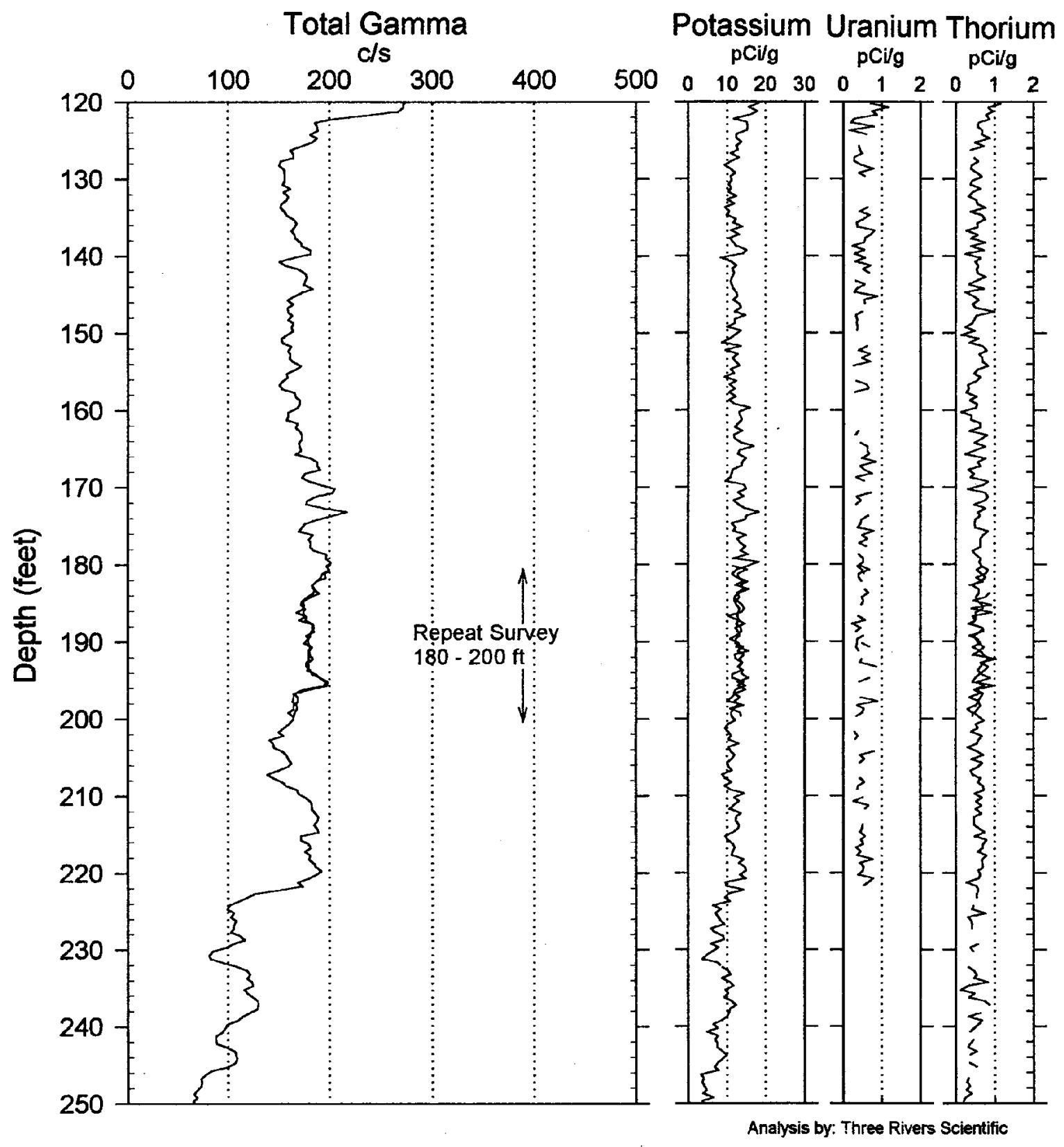




\section{RLS Spectral Gamma Ray Borehole Survey Waste Management Federal Services}

Project: 2000 RCRA Drilling

Borehole: 299-W14-17
Log Date: October 17, 2000 Naturally Occurring Radionuclides

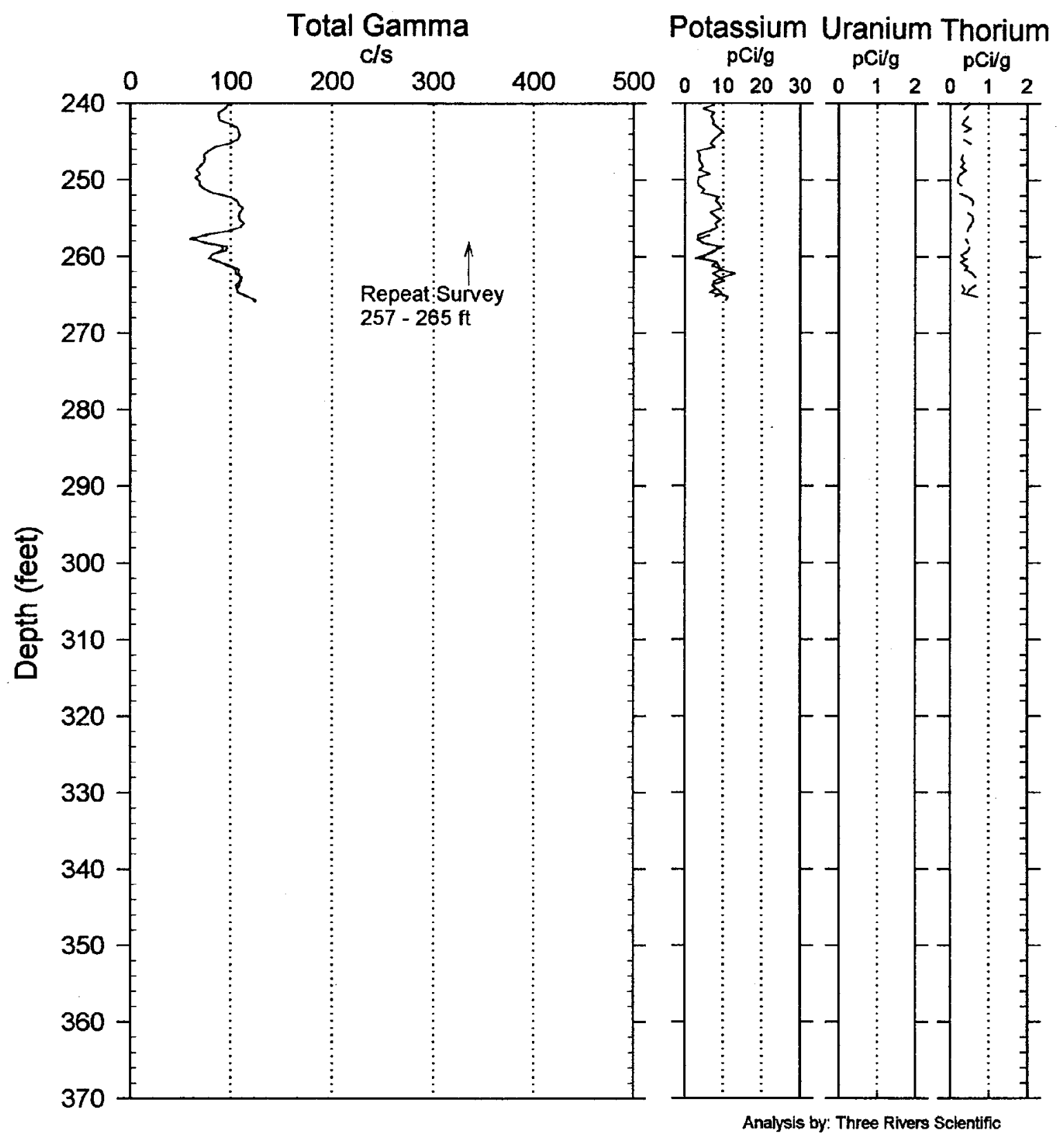




\title{
Spectral Gamma Ray Log Analysis \& Summary \\ Waste Management Federal Services
}

\author{
Project: $\quad 2000$ RCRA Drilling \\ Well: \\ 299-W14-17 \\ Log Type: $\quad$ HPGe Spectral Gamma Ray \\ Log Date: October 17, 2000
}

\section{General Notes:}

Total gamma is a response to geologic concentrations of natural radionuclides. Two changes in sensitivity of gross gamma to geologic concentrations of natural radionuclides occur at the dual casing change ( $20.6 \mathrm{feet})$ and the water level (222 feet).

Log data collected with a depth reference of ground surface.

System Performance Verify: The pre- and post-log verification passed performance standards; a $-1.1 \%$ change was observed in the gross. The FWHM of the $583 \mathrm{keV}$ photo peak was also within specifications for pre- and postlog verification.

Repeat Interval: Based on the repeat interval, the logging system performed as per specifications.

Environmental Corrections: All radionuclide concentrations have been corrected for casing attenuation (entire well). Water correction was applied to depths deeper than 222 feet. No casing correction was applied to the total gamma due to Compton downscatter interference.

\section{Radionuclides:}

No man-made radionuclide contamination was detected.

The natural uranium concentration is below detection threshold from 0 to 20.6 feet, and from 222 to 265 feet. Both of these intervals have additional gamma attenuation due to dual casing from 0 to 20.6 feet and the water annulus from 222 to 265 feet. The changes in gross gamma from 85 to 123 feet are reflected by changes in potassium, uranium, and thorium; which is indicative of geologic effects. 


\section{Neutron-Neutron Moisture Borehole Survey \\ Waste Management Federal Services}

\section{Log Header}

Project: $\quad 2000$ RCRA Drilling

Well: 299-W14-17

\section{Log Type: Moisture Gauge}

Borehole Information

\begin{tabular}{|c|c|c|c|c|}
\hline Well \# C3121 & Water Depth & $\underline{222}$ & \multicolumn{2}{|c|}{ Total Depth $264.3 \mathrm{ft}$} \\
\hline Elevation Reference $\underline{n} / \mathbf{a}$ & Elevation & $\underline{n} / \mathbf{a}$ & & \\
\hline Depth Reference Ground Surface & Casing Stickup & 0.5 & & \\
\hline Casing Diameter $10.125 \mathrm{ID}$ in & Depth Interval & 0 to $20.6 \mathrm{ft}$ & Thickness & 0.75 in \\
\hline Casing Diameter $7.625 \mathrm{ID}$ in & Depth Interval & 0 to $264.3 \mathrm{ft}$ & Thickness & 0.5 \\
\hline
\end{tabular}

\section{Logging Information}

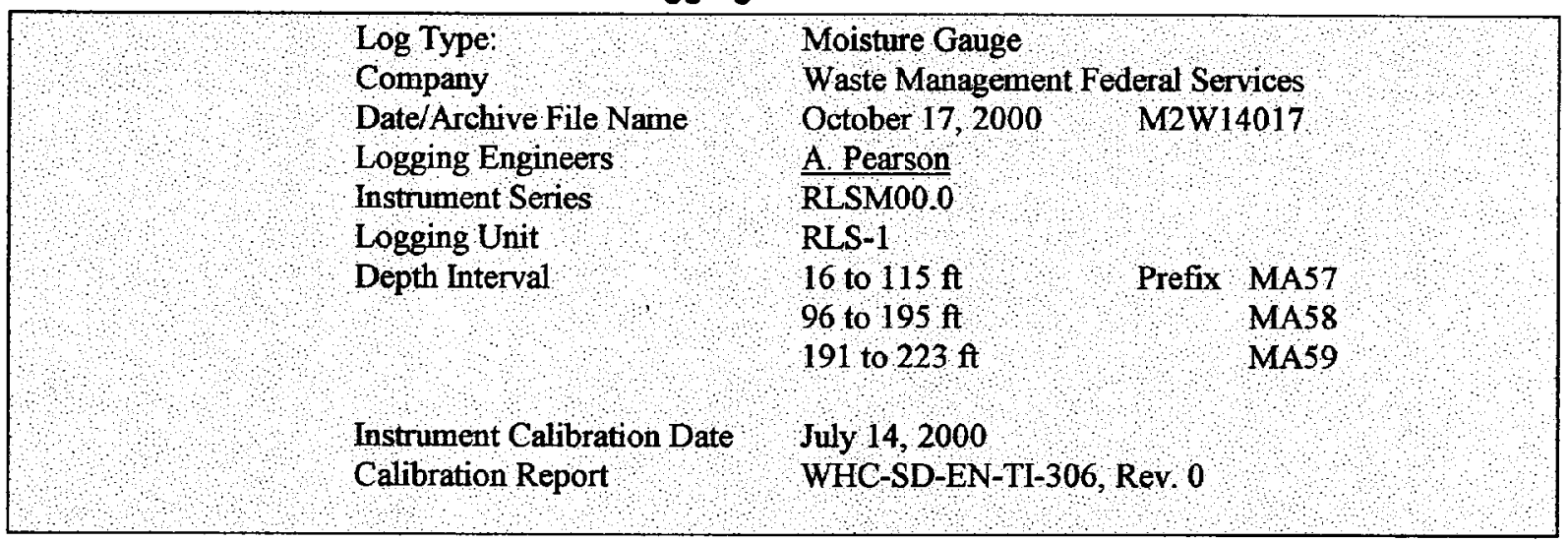

Analysis Information

$\begin{array}{lll}\text { Company } & \text { Three Rivers Scientific } \\ \text { Analyst } & \text { Russ Randall } \\ \text { Date } & \text { November 2, 2000 }\end{array}$

Notes Moisture values range from $2 \%$ to $20 \%$ for the depths logged. The onset of high readings at 222 feet is due to the proximity of the water level in the borehole. No valid calibration is available for the 10 inch casing diameter from surface to 20.6 feet thus the application of the 8 inch calibration is plotted as a blue line (with circle symbols) over 16 to 20.6 feet. 


\title{
RLS Neutron-Neutron Moisture
}

\author{
Waste Management Federal Services \\ Project: 2000 RCRA Drilling \\ Borehole: 299-W14-17 \\ Log Date: October 17, 2000 \\ Depth Datum : Ground Surface
}
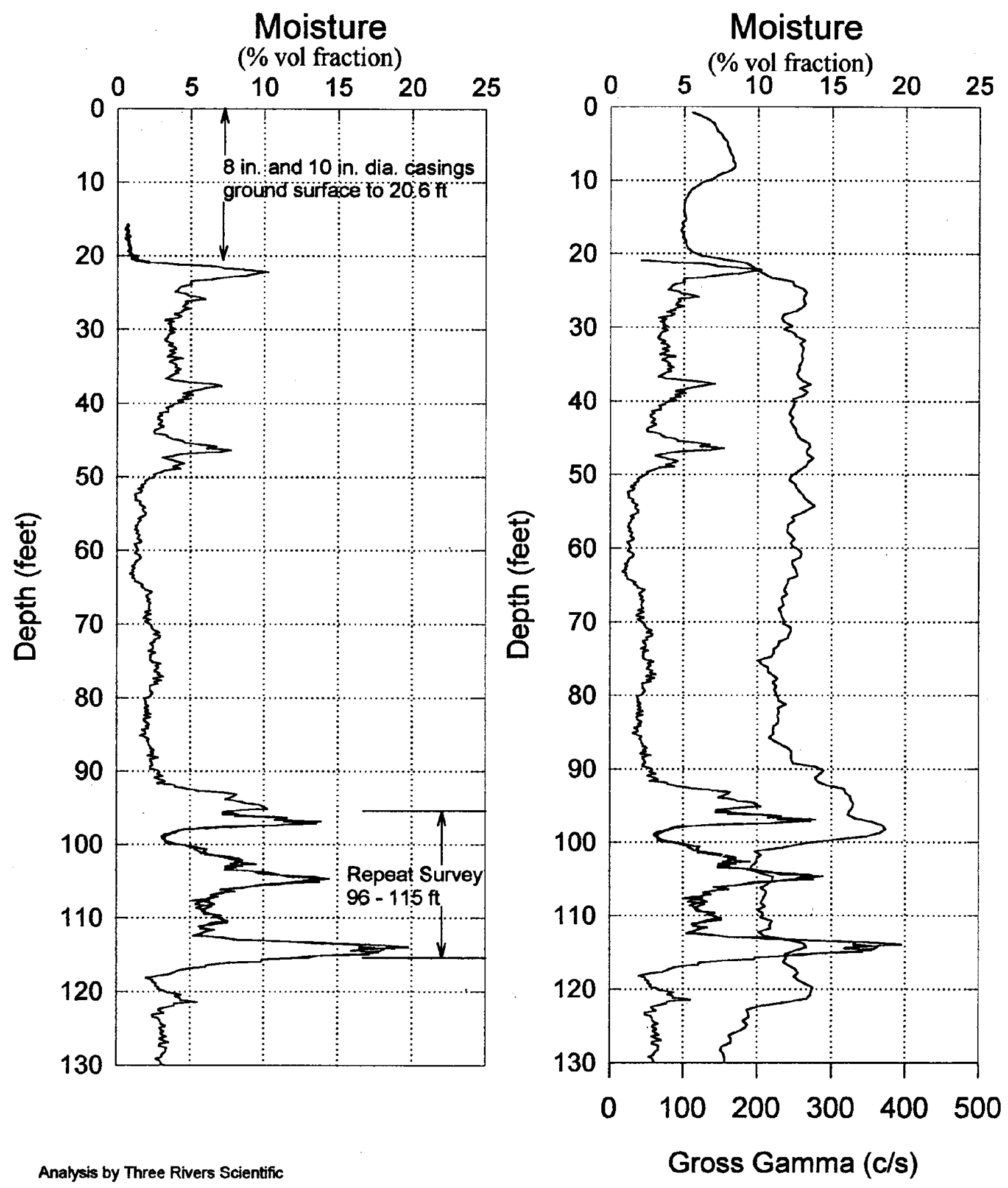

Analysis by Three Rivers Scientific 


\title{
RLS Neutron-Neutron Moisture
}

\author{
Waste Management Federal Services \\ Project: 2000 RCRA Drilling \\ Borehole: 299-W14-17 \\ Log Date : October 17, 2000 \\ Depth Datum : Ground Surface
}
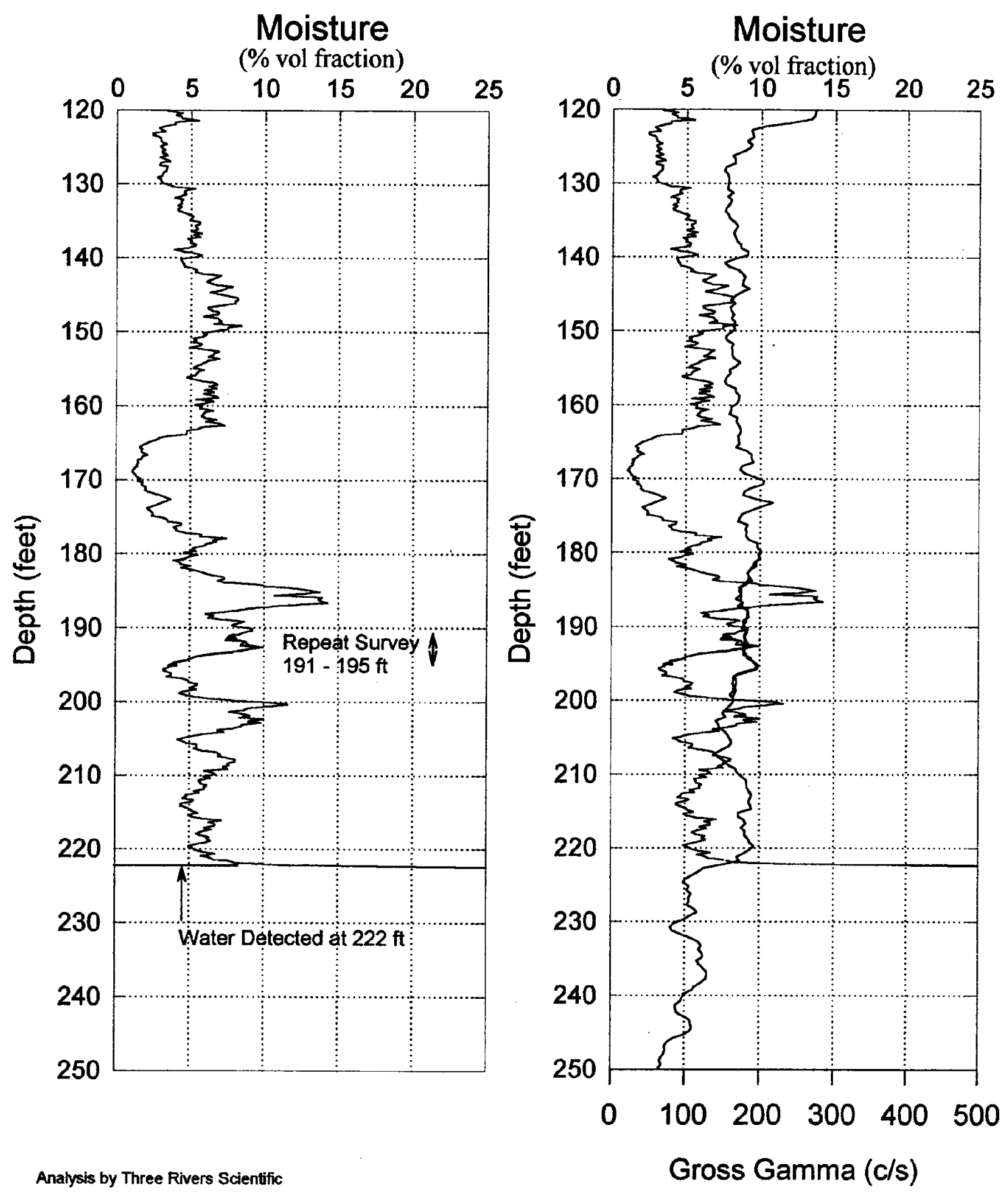


\section{Moisture Log Analysis \& Summary Waste Management Federal Services}

\author{
Project: $\quad 2000$ RCRA Drilling \\ Log Type: Moisture Gauge
}

Well ID:

299-W14-17

Log Date: October 17, 2000

\section{General Notes:}

The 8 inch calibration coefficients were used for all logged depths. The 8 inch calibration standard has an 8.64 inch borehole diameter, with .32 inch casing thickness, and the borehole diameter in these log data is 8.625 inches. The depth interval from 16 to 20.5 feet has both the 8 inch and 10 inch casing. Thus the inappropriate use of the 8 inch calibration from 16 to 20.5 feet is plotted with a blue line and circle symbols. Note: no calibration exists for the 10 inch casing.

Log data collected with a depth reference of ground surface.

System Performance Verify: The pre- and post-log verification passed performance standards, $+0.4 \%$ change from start of $\log$ to end of $\log$, in the shield verify.

Repeat Interval: Based on the repeat interval from 96 to 115 feet and 191 to 196 feet, the 'logging system performed according to specifications.

Environmental Corrections: The moisture levels have been corrected for casing thickness ( 0.5 inch) for all well depths logged. No formation density correction has been applied because density values are not available.

\section{Observations:}

The moisture levels show values ranging from $2 \%$ to $20 \%$ for the depth interval from 20.6 feet to 222 feet. The abnormally high readings that begin at 222 feet are a response to the water level at 222 feet.

Thin wetter zones exist at 22,38 , and 47 feet. A highly laminated structure of wetter zones bounded by drier zones exists from 92 feet to 123 feet. Over this interval ( 92 to $123 \mathrm{feet}$ ) there is a good correlation between the gross gamma and the moisture structure, which is indicative of geologic variations.

Variable moisture structure shows from 172 to 210 feet. Over this depth interval, there is no good correlation with the gross gamma signature. Therefore, moisture content is sensitive to the geologic structure over this interval, while the changes in natural radionuclides is not sensitive to the geologic structure. 


\section{Distribution}

No. of

Copies

OFFSITE

Confederated Tribes of the Umatilla Indian Reservation

Environmental Planning/Rights Protection P.O. Box 638

Pendleton, OR 97801

ATTN: J. R. Wilkerson

L. Seelatsee

Wanapum Band

Grant County P.U.D.

30 "C" Street S.W.

P.O. Box 878

Ephrata, WA 98823

P. Sobotta

Nez Perce Tribe

Environmental Restoration/Waste

Management

P.O. Box 365

Lapwai, ID 83540-0365

Confederated Tribes and Bands of the Yakama Nation

Environmental Restoration/Waste

Management

2808 Main Street

Union Gap, WA 98903

ATTN: R. Jim
No. of

Copies

3 CH2M HILL Group
A. J. Knepp (2)
$\mathrm{H} 0-22$
D. A. Myers
$\mathrm{H} 0-22$

2 CH2M HILL Hanford, Inc.

J. V. Borghese H9-03

D. C. Weekes H9-02

3 Washington State Department of Ecology

B. Goswami B5-18

A. D. Huckaby B5-18

M. Brown B5-18

U.S. Environmental Protection Agency

$\begin{array}{ll}\text { C. A. Faulk } & \text { B5-01 }\end{array}$

14 Pacific Northwest National Laboratory

D. N. Hodges (3) K6-81

D. G. Horton (3) K6-81

S. P. Luttrell K6-96

W. J. Martin K6-81

F. A. Spane K6-96

B. A. Williams K6-81

Hanford Technical Library (2) P8-55

DOE Public Reading Room (2) H2-53

\section{ONSITE}

\section{DOE-RL}

M. J. Furman (2)

R. M. Yasek

A5-13

H6-60 